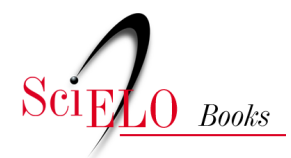

\title{
Segunda parte \\ La contestación social
}

Victor Hugo Torres Dávila

\section{SciELO Books / SciELO Livros / SciELO Libros}

TORRES DÁVILA, V. H. La contestación social. In: Hegemonías y subalteridades urbanas: la configuración metropolitana de Quito [online]. Quito: Universidad Andina Simón Bolívar, Sede Ecuador; Editorial Abya-Yala, 2020, pp. 213-433. Investigación Decolonial series, n. 4. ISBN: 978-9978-10-456-9. http://doi.org/10.7476/9789978105757.0006.

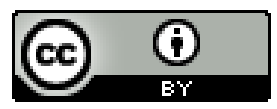

All the contents of this work, except where otherwise noted, is licensed under a Creative Commons Attribution 4.0 International license.

Todo o conteúdo deste trabalho, exceto quando houver ressalva, é publicado sob a licença Creative Commons Atribição 4.0.

Todo el contenido de esta obra, excepto donde se indique lo contrario, está bajo licencia de la licencia Creative Commons Reconocimento 4.0. 
Segunda parte LA CONTESTACIÓN SOCIAL 

La acción colectiva de las organizaciones barriales emergió en lugares específicos de la ciudad, en los perímetros geográficos de los barrios populares y periféricos de Quito. Las luchas barriales, gestadas en el proceso metropolitano capitalino, se tomaron los espacios públicos y activaron a diversos actores sociales movilizados por plurales intereses respecto del hábitat popular, las condiciones de reproducción social y material, las identidades culturales urbanas y en general en torno a la vida en la ciudad. Recrearon sus repertorios de acción colectiva, en pos de sus demandas y derechos.

La contestación social se refiere a las diversas formas que adquirió la acción colectiva en el proceso metropolitano quiteño, a las luchas del movimiento organizado de los barrios periféricos, a las acciones desde la alteridad como la resistencia de las comunas ancestrales, a las inserciones diferenciadas de los migrantes indígenas, a la defensa de la identidad del pueblo afroquiteño, y a las recientes movilizaciones políticas de las clases medias; todas expresiones político-culturales de la compleja configuración de la moderna sociedad urbana.

Las formas de contestación social forman parte del proceso de expansión metropolitano. El crecimiento desordenado de la ciudad dio lugar al surgimiento de las organizaciones barriales, en respuesta a las condiciones de exclusión y segregación periférica, a la reactivación de las comunas ancestrales ante la presión inmobiliaria; atrajo la migración indígena y campesina de las provincias circundantes que reprodujeron redes comunitarias de inserción en la ciudad, al igual que las tramas de afinidad entre la población afro desplazada por la reforma agraria y afincada en los barrios periféricos. A su momento, los propios habitantes nativos de la ciudad también protagonizaron algún tipo de movilización urbana.

Fueron expresiones de inéditas configuraciones societales activadas con el tránsito de la ciudad tradicional a la moderna urbe metropolitana, por lo que la contestación social no alude solo al comportamiento reactivo de un grupo social determinado al proceso metropolitano de Quito, como podría pensarse del movimiento barrial, cuestión que como se argumentará en las sucesivas páginas no ocurrió en la ciudad. 
Con el título de contestación social me refiero al carácter dinámico de los diversos actores urbanos surgidos en el proceso metropolitano, a sus demandas, acciones y ciclos de duración. Se alude a la contemporaneidad de los otros en la ciudad, a la situación de aquellos en tensión con las maneras de las élites y el poder (Kingman 2008). El movimiento barrial quiteño surgido en los barrios periféricos experimentó, al compás de la expansión metropolitana, una mutación desde sus inicios vecinales, al auge de la lucha poblacional y posteriormente al declive ciudadano.

Por fuera del movimiento barrial se configuró un pluriverso popular urbano, conformado en las intersecciones culturales de los viejos y nuevos protagonismos de la sociedad quiteña, especialmente el proceso de etnogénesis de las comunas ancestrales de identidad kitu kara, la inserción diferenciada de los indígenas migrantes devenidos en residentes de la ciudad y las tribulaciones en la inserción, igualmente diferenciada, del pueblo afroquiteño, enfrentado a los estigmas de la sociedad blanco-mestiza.

En simultáneo, y en un plano diferente, las clases medias y altas de la ciudad protagonizaron movilizaciones políticas de protesta, activadas en defensa de la capitalidad frente al desorden político presidencial, confirmando el simbolismo del orden regulatorio de la ciudad. 


\section{Capítulo III}

\section{EL MOVIMIENTO BARRIAL EN QUITO METROPOLITANO}

Las luchas del movimiento barrial expresan las disputas por el lugar en la ciudad; irrumpieron en los bordes espaciales y simbólicos de la urbe metropolitana, adquiriendo concreción con sus rituales presencias colectivas en los espacios públicos, donde ocurrieron los encuentros con otros actores populares que cualificaron a las luchas barriales.

El movimiento barrial quiteño surgió y se expresó circunscrito a los barrios periféricos en los costados de la ciudad, en su momento de mayor protagonismo llegó a agruparse por zonas interbarriales, e instituyó las liturgias simbólicas de uso de segmentos marginales del espacio público en la ciudad. El movimiento barrial capitalino surgió en la territorialidad propia de los barrios periféricos, en sus disputas se desplazó por determinados perímetros del espacio público capitalino, por lo que su comprensión implica adentrarse en la geografía de los barrios populares de la ciudad metropolitana.

A diferencia de la mesoescala espacial del proceso metropolitano que alude al cantón convertido en distrito metropolitano, ya que la macroescala está en correspondencia con la región en la que se inserta la ciudad capital, la microescala espacial, como he dicho, se refiere a la geografía de las luchas barriales, al territorio de los asentamientos populares en el que surgieron las presiones colectivas por hábitats dignos, en medio de condiciones adversas. Se refiere al lugar de las luchas barriales y sus organizaciones.

El análisis del movimiento barrial nos conduce ineluctablemente por la microescala espacial de la acción colectiva urbana, si bien con débiles protagonismos populares en reacción a las dinámicas espaciales de la ciudad y aislados de las tendencias regionales en las que se asienta la urbe. 
Se trata de un movimiento barrial autorreferido, volcado sobre sí mismo en las demandas urbanas y desarticulado de las luchas sociales mayores.

En el tercer capítulo analizo el ciclo de duración del movimiento barrial quiteño, surgido en el proceso de expansión metropolitana de la ciudad, subrayando cómo la emulación cultural afectó a la acción colectiva de las organizaciones barriales, sus deslizamientos entre los intereses colectivos y el personalismo de las dirigencias, y el nexo con el municipio capitalino que en los distintos períodos marcó sus alcances políticos.

El capítulo está dividido en tres secciones: la primera, a manera de introducción, argumenta los vínculos entre los movimientos sociales y las racionalidades urbanas; la segunda sección discute la levedad cultural de los barrios periféricos como condición material de la transitoriedad organizativa; y la tercera interpreta el ciclo del movimiento barrial quiteño, diferenciando entre los períodos de inicio en el tránsito de la ciudad conventual a la urbe moderna, el auge durante la expansión metropolitana, y el declive, paradójicamente, en medio de la consolidación del distrito metropolitano.

\section{Movimientos sociales y racionalidades urbanas}

La comprensión de las luchas barriales desde la perspectiva de su potencialidad como movimiento popular urbano supone adentrarse en el análisis del universo de las organizaciones barriales, de vivienda y poblacionales, descifrar sus capacidades para actuar en redes, canalizar recursos, innovar los liderazgos y movilizarse en los espacios públicos para presionar a las autoridades, lo que podría verse como sus repertorios de acción colectiva. Capacidades que en el caso de las organizaciones barriales quiteñas, desde el inicio, estuvieron relacionadas con el clientelismo de los partidos políticos y las autoridades municipales, con la influencia de las organizaciones de la sociedad civil, con las cualidades de autogestión de los pobladores en su afán por lograr tierra y vivienda urbana, configurando un escenario de luchas barriales cuyo, telón de fondo era la subjetividad colectiva de emulación del orden simbólico de la ciudad.

Los pocos estudios sobre el movimiento barrial quiteño (García 1985, Unda 1996, Borja 2011, Barrera 2011) coinciden en señalar el epi- 
sódico protagonismo de sus organizaciones, en anotar que las capacidades de movilización barrial se incrementaron en el encuentro público con otros actores políticos y sociales, y en mostrar que el aumento cuantitativo de sus organizaciones era correlativo con la expansión urbana y el surgimiento de numerosos barrios periféricos en condición irregular. No voy a repasar estos aspectos por demás ciertos, me enfocaré, más bien, en las subjetividades colectivas de las organizaciones barriales, con las que, junto con las demandas de tierra, vivienda, equipamiento y servicios, buscaban extender, simbólicamente, en los barrios segregados el estatus primado de la ciudad.

El movimiento barrial quiteño luego de una larga trayectoria de luchas viviendísticas, con protagonismos cohesionadores de los intereses de los barrios periféricos y populares, desembocó en una dispersión organizativa que fragmentó los intereses barriales en atomizadas demandas del derecho a la ciudad. Múltiples sujetos populares quedaron como secuela de la ola del movimiento barrial, una vez que este traspasó el umbral del no retorno de la modernidad metropolitana de Quito, cuando la desintegración organizativa reemplazó a las federaciones barriales.

En la transición a distrito metropolitano el movimiento barrial no se propuso un proyecto de ciudad alternativa, basado en la convergencia de los diversos intereses, organizaciones y sujetos populares que cuestionen la preeminencia simbólica y espacial del orden metropolitano. No solo porque la institucionalización metropolitana es reciente, sino porque las organizaciones barriales operaron como dispositivos socioculturales de inserción de la población de los asentamientos periféricos, en la modernización de la ciudad. Sus acciones no buscaban cuestionar el modelo metropolitano, sino su concurrencia, no se trataba de alterar el orden sino de asumirlo, no obstante que a momentos la contestación de las luchas barriales asumió matices de rebelión.

En la explicación de lo ocurrido con el movimiento barrial capitalino, en un escenario urbano sellado por el progreso y la modernidad capitalistas, considero pertinente señalar los momentos de condensación de los denominados conectores culturales o subjetividades colectivas, referidos a las narrativas ideológicas como vectores de emulación 
cultural, con las cuales las organizaciones barriales involucraron a significativos contingentes de moradores en las luchas por el acceso a la tierra, vivienda, infraestructura, servicios y equipamiento urbano.

Como lo han establecido diferentes autores, no es suficiente entender los conectores culturales como espacios de interacción simbólica específicos y correspondientes a situaciones singulares de grupos o colectividades urbanas, sino también en referencia al sistema completo de significación en el que están conectados, del que obtienen y al que envían significados colectivos como la sociedad o la nación (Tejerina 1998). En nuestro caso, supone comprender las subjetividades colectivas de las luchas barriales en Quito, especialmente en coyunturas de relevancia pública en las que se expresaron las expectativas de integración urbana, junto con el cuestionamiento a la segregación desde el antagonismo de la diferencia cultural.

Las subjetividades colectivas que activan la interacción entre personas, organizaciones e instituciones en la ciudad están estrechamente relacionadas con maneras de comprender el poder local y el espacio público, con lecturas compartidas entre los sujetos urbanos acerca de la ciudad, su gobierno, la convivencia y el territorio. Podría decirse que están relacionadas con modos epistémicos claramente influyentes en las conciencias asociativas, grupales, comunales, barriales y colectivas que son decisivas en las prácticas organizativas y en las acciones barriales. No estoy afirmando que las ideas determinaron mecánicamente al movimiento barrial, sino que las maneras en que se formularon los intereses colectivos que movilizaron colaborativamente a las personas y las formas organizativas que asumieron estuvieron relacionadas también con maneras de percibir, sentir y ser respecto al orden en la ciudad.

\section{Culturas y acción colectiva barrial}

Los nexos culturales del proceso percepción-conciencia-acción colectiva son claramente modernos, forman parte de las concordancias o discrepancias de las agrupaciones de personas y sus organizaciones con el adelanto capitalista; surgen especialmente en los lugares donde debido a sus condiciones socioeconómicas y culturales son relegados 
por el discriminatorio ordenamiento espacial. De acuerdo con Benjamín Tejerina (1998), la ciudad, o la urbanización, es uno de los mayores productores de modernización social porque condensa en su interior instituciones anudadas como la privatización de la vida y la economía, la estratificación social, los sistemas de educación o los medios de comunicación, aunque en realidad, dice Tejerina, la producción tecnológica y la burocracia son los "portadores primarios más influyentes en el universo simbólico dominante en las sociedades modernas” (120).

El autor se refiere a que en estas instituciones un aspecto central es la formación de la conciencia como una suerte de bastidor de sentidos o significados, que permite a las personas "pilotar" entre los acontecimientos cotidianos y en los encuentros con otras personas, basado en el influjo de la economía tecnológica creadora de un estilo cognitivo que afecta a la conciencia en aspectos como la componencialidad, la separación medios-fines, la individualidad de las relaciones sociales y la maximización de la multirelacionalidad, mientras lo burocrático moldea a la conciencia en lo metódico, la propensión a lo taxonómico, lo organizacional, lo predecible y al sentimiento de anonimato (119-20), explica.

Las instituciones urbanas del mercado y el municipio, que funcionan en situaciones dicotómicas de distinción de las esferas pública y privada, son las principales usufructuarias de los avances aplicados de la ciencia y la tecnología, y los mayores vectores urbanos por los que discurre la racionalidad moderna que moldea las percepciones individuales y la conciencia colectiva del progreso como expectativa de vida y sentido común.

A manera de correlato, o la otra cara del proceso percepción-conciencia-acción moderna, se encuentra la emulación cultural del orden en la ciudad, esto es la necesidad generalizada en la población de reeditar el estatus social de los privilegios urbanos. Institucionalizada por el poder local, se asume la segregación como algo propio al crecimiento urbano que también discrimina a la diferencia cultural, alejándola de los primados lugares urbanos y encajonándola en los márgenes de la ciudad.

En la urbe es determinante el peso de la racionalidad moderna en las acciones colectivas de las personas y organizaciones. En medio de 
las resistencias o adscripciones a la individualización que conlleva la expansión urbana, se expresan los descontentos populares ante la ausencia o precariedad de los servicios públicos, al igual que las consecuencias de las excluyentes políticas municipales que afectan en varios ámbitos de la vida a significativos contingentes de moradores; activándose, en respuesta, las movilizaciones de las organizaciones barriales en la escena pública, convertida en la arena prioritaria de la acción colectiva y de las demandas ciudadanas.

En la compleja dinámica de organización y movilización barrial capitalina predominaron las ideas y valores liberales que ahondan en el individualismo de las personas, haciéndoles refractarias a las posibilidades asociativas, al tiempo que fragmentan las expectativas barriales y colocan a los pobladores de los barrios periféricos en posición de pragmático enrolamiento con el progreso urbano. Y es que el liberalismo forma parte de la ideología del poder local que planea sobre las culturas de la ciudad y reproduce, entre sus habitantes, la necesidad material y existencial de emulación del orden y las jerarquías de la ciudad.

La racionalidad de lo urbano moldea las formas de percepción-conciencia-acción y delimita el horizonte de las prácticas colectivas, al igual que las formas de organización y lucha barrial. Muestra de ello es que las movilizaciones barriales emplean algún tipo de agenda institucional o sistémica, recurren a medios de presión para su consecución, buscan congregar la mayor cantidad de relaciones con otros grupos en similar situación y, aunque reconocen liderazgos, se inclinan por el anonimato de sus miembros.

Las movilizaciones de los barrios periféricos quiteños, en su mayoría, recrearon las formas de acción racional con arreglos medios-fines para la consecución de bienes y servicios públicos que mejoren las condiciones de vida, en una suerte de realismo urbano que procesa los problemas de segregación espacial, estigmatización cultural y carencias materiales como limitantes de la convivencia en la ciudad. En los barrios periféricos estos problemas tienden a asumirse como privaciones que requieren modificaciones materiales, combinando la presión de las movilizaciones barriales con la reactividad de las autoridades locales que 
ocurren, generalmente, en contextos de intercambio de lealtades por servicios públicos. Este comportamiento, sin dejar de ser clientelismo, es visto también por las dirigencias barriales como una manera de ser sujetos portadores de los valores prescriptivos de la ciudad, con los que pueden gestionar aquello de lo que se carece.

De ahí el predominio de un pragmatismo inmediatista en las acciones de los líderes y organizaciones de los barrios periféricos, en las que confluyeron otros sujetos populares como los indígenas urbanos, el pueblo afroquiteño, las juventudes urbanas y las organizaciones de mujeres que también se encuentran en tensión con el modelo urbano y son portadores de experiencias forjadas desde la alteridad, en las que se entrelazan afanes de progreso con expectativas por una ciudad inclusiva. El encuentro entre los diversos sujetos populares abre posibilidades interculturales a la acción colectiva urbana, proyectándole más allá de la inmediatez de la dirigencia barrial.

Las movilizaciones barriales, que sucedieron en Quito en el transcurso de la segunda mitad del siglo XX, estuvieron estrechamente ligadas con visiones compartidas o en tensión sobre el simbolismo metropolitano de la ciudad, y con conciencias igualmente convergentes o en resistencia sobre la convivencia en la capital, cuyos variados significados estuvieron, y están, en la raíz de las luchas barriales. Sinnúmero de habitantes de Quito se movilizaron con ciertas percepciones-conciencias sobre los principales hechos urbanos, levantando demandas de acceso a servicios básicos, legalización de tierras, usos interculturales del espacio público, y generaron, en determinados momentos, acciones colectivas y protagonismos interclasistas con repercusiones políticamente significativas.

En el trasfondo de las movilizaciones barriales del período, prevaleció la adscripción al sentido modernizante metropolitano que fue compartido por amplios sectores sociales de la ciudad, en el que sobresale la idiosincrática predisposición criolla, vernácula, a replicar el modo de vida urbano occidental, asumido como la imagen del orden deseado de ciudad. Las autoridades locales, los medios de comunicación, los líderes políticos, las agrupaciones gremiales, las universidades, las organizaciones no gubernamentales, las organizaciones barriales y en general la 
mayoría de las gentes quiteñas concuerdan en una ciudad de imágenes superpuestas, esto es una urbe planificada con vías de circunvalación y monumental, una ciudad empresarial con megacentros comerciales estratificados según el consumo y mercados segmentados, y una ciudad democrática con habitantes cultores de la libertad individual.

Junto con los estratos sociales medios y altos, conviven los sectores populares que anhelan igualmente, a su modo, el modelo urbano de imágenes superpuestas, con el que construyen sus propios caminos de inserción en la ciudad. Entre ellos están los habitantes de los barrios del sur, de los barrios en las periferias urbanas y periurbanas circundantes, de las lotizaciones formadas con tenencia informal del suelo en exhaciendas, antiguos huasipungos, de asentamientos humanos en quebradas, hondonadas y zonas de riesgo, de las comunas indígenas acorraladas por la expansión urbana, donde la pobreza sobrepasa a la mayoría de la población.

Son los sitios de residencia de grupos humanos que expresan la heterogeneidad estructural y la diferencia cultural de la sociedad quiteña, a los que se estigmatiza como inferiores por atávicos dispositivos discriminatorios y raciales de la segregación urbana. Diríamos, usando la expresión de Franz Fanon (1991), son los lugares de asiento de los "condenados" de la ciudad, de aquellos que resisten en preexistentes y nuevas espacialidades configuradas desde la alteridad urbana, lo que contrasta con la imagen generalizada de que la capital tiene las mejores condiciones de vida del país. En los hechos, la ciudad deseada de imágenes superpuestas se parece más, con las diferencias de contextos históricos y escalas urbanas, a la "ciudad de la difícil equidad" a la que se refiere el historiador del urbanismo Peter Hall (1996), donde los "condenados" de la ciudad sobreviven en colectividades que se encuentran en tensión con la metrópoli urbana.

En dichos años la ciudad experimentó una acelerada expansión urbana y un agresivo avance de la racionalidad moderna. La renovación urbana de barrios tradicionales y antiguas zonas residenciales dieron, y dan paso, a novísimas áreas productivas, comerciales y de servicios; la apertura de vías que enlazan los valles circundantes provocan des- 
plazamientos poblacionales y modalidades de centrifugación social con nuevas segregaciones urbanas. La mancha urbana se expandió desproporcionadamente, sometiendo a la ruralidad con todas las consecuencias de mutación del hábitat, el territorio, las economías solidarias y las formas de vida, cuyas expresiones culturales, en el mejor de los casos, son encapsuladas en el folclore urbano.

La racionalidad moderna no solo modifica la morfología de la ciudad, sino que supedita a los diferentes epistemes colectivos y a las sabidurías populares a las distintas iniciativas de organización popular y a las preexistentes formas de acción comunitaria, en principio contestatarias y luego acopladas como eventos del proceso de construcción de ciudad, acorde con el liberalismo individual que ve en lo comunitario, en lo solidario y en la reciprocidad vestigios de un pasado reñido con el progreso. En Quito, las movilizaciones barriales del período estuvieron atravesadas por divergentes significados de convivencia, así como por encuentros entre actores, discursos, liderazgos e identidades urbanas que estuvieron tensionadas entre las necesidades de la reproducción social de la población barrial y su funcionalidad individual de inserción económica y mercantil.

No busco analizar los múltiples elementos simbólicos que enlazan las dinámicas de la sociedad y las culturas quiteñas como un todo complejo. Me intereso solo en las movilizaciones barriales en el proceso metropolitano y dejo de lado, deliberadamente, otras expresiones sociales masivas o multitudinarias como las organizaciones deportivas barriales entrampadas en relaciones clientelares que reivindican lo deportivo desvinculado de lo recreativo; al igual que las manifestaciones religiosas y rituales que en los barrios y parroquias rurales siguen calendarios de sincretismo cultural; las festividades cívicas cargadas de simbolismos locales que concitan masivas reuniones públicas, con las que se reifican los procesos identitarios urbanos; o los tumultuosos rituales de las barras e hinchadas de los equipos profesionales de fútbol y sus cotidianas irrupciones en el espacio urbano.

Tampoco incluyo otras expresiones larvarias de asociatividad como los grupos de ciclistas y peatones preocupados por la movilidad 
alternativa y la contaminación ambiental, o los colectivos inquietos por las políticas urbanas diferenciadas según la condición sexual y de género. Se trata, en todos los casos, de iniciativas asociativas con diversos intereses urbanos que no empalmaron con el movimiento barrial, porque cada una tiene sus propios "lugares de enunciación", y dado el alcance del presente estudio sería pretensioso incluirlas.

Como se comprenderá tampoco cabe llevar el análisis más allá de su utilidad para interpretar las movilizaciones barriales quiteñas. Me circunscribo a la narración e interpretación de los principales eventos en torno a lo que genéricamente puede considerarse como luchas contestatarias urbanas, especialmente las que tuvieron como referencia los esfuerzos de integración de los barrios periféricos en un contexto urbano cruzado por la segregación y la hegemonía cultural.

\section{Lugares y narrativas periféricas quiteñas}

¿Por qué el movimiento social de los barrios periféricos y populares de Quito, pese a protagonizar un intenso itinerario de luchas por la tierra, vivienda y servicios, no logró consolidarse como un interlocutor estable de la política urbana municipal? ¿Qué factores culturales intervinieron para que las luchas barriales, en lugar de cuestionar y disputar la modernización metropolitana de la ciudad, optaran más bien por su emulación?

En la explicación cultural de los alcances del movimiento barrial capitalino concurren tres elementos que considero relevantes: el primero se relaciona con el fraccionamiento simbólico del espacio público capitalino en que se encapsuló al movimiento barrial; el segundo se refiere a las subjetividades colectivas de las organizaciones barriales, afines al orden, y el tercero alude a la relatividad espacial de lo barrial respecto de la ciudad que confinó a una condición transitoria a sus organizaciones.

Triada que desde su génesis marcó el devenir del movimiento barrial capitalino, por lo que en el análisis, necesariamente, adopto una visión del conjunto de los períodos, actores y narrativas, que requiere ampliar la mirada especialmente hacia el período de conformación del movimiento barrial. El desplazamiento temporal, lo diacrónico, se vuelve inevitable en la comprensión de la acción colectiva barrial, es impres- 
cindible en la caracterización de las continuidades y rupturas culturales que permiten argumentar el ciclo del movimiento barrial capitalino.

\section{El espacio público fragmentado}

En relación con los espacios públicos simbólicamente diferenciados de la ciudad, cabe anotar que la coexistencia en Quito de numerosos y heterogéneos barrios populares y periféricos, de plurales colectividades urbanas y de individuales expectativas de vida, requirió del marco institucional articulador del distrito metropolitano reseñado en el segundo capítulo, por el que discurren desigualmente los bienes y servicios públicos, conjuntamente con las tensiones y disputas identitarias urbanas. Uno de los aspectos centrales de lo local en el ámbito metropolitano está relacionado con el espacio público de la ciudad, en el que se sintetizan el orden y las jerarquías del poder, la cohesión social, los intercambios económicos y culturales, y los sitios en los que la sociedad urbana en su diversidad y heterogeneidad se expresa políticamente (Borja 2011, 321-3).

Condicionados por la concertación elitista de la política urbana y la gestión de la ciudad, los espacios públicos quiteños rebelan las tensiones entre las áreas integradas y las segregadas, entre los lugares y no lugares entretejidos, al mismo tiempo separados, por el capital inmobiliario y financiero que ordena el territorio en áreas de inversión y expansión urbana y en áreas prescindibles o residualmente incorporadas a la ciudad.

En el DMQ no se configuró un mismo y único espacio público en el que se expresen pluralmente la diversa sociedad local, sino que, paradójicamente, se instituyeron disímiles espacios públicos diferenciados simbólicamente en los que prevalecieron los intereses privados y el poder local por sobre los intereses colectivos relativos al vivir bien en la ciudad y eventuales propuestas de democratización urbana. El espacio público quiteño está constituido por un entramado de fracciones de espacios estatales, municipales, privados, barriales, comunitarios y colectivos que se encuentran tensionados por las disputas de sus habitantes, organizaciones e instituciones. 
Las organizaciones barriales provivienda en sus demandas de servicios, infraestructura y legalización de tierras, tendieron a ocupar su propio espacio público al movilizarse principalmente por la extensa ciudad "sureña”, por los costados y derredores periféricos, enlazando prácticas colectivas, comunitarias e individuales que confirieron identidades a determinados lugares del suroriente y noroccidente de la ciudad popular.

No siempre supieron canalizar los diversos intereses de su población heterogénea, por lo que en paralelo y al interior de los barrios periféricos surgieron otros colectivos populares que desde el antagonismo de la exclusión y del no lugar se movilizan en los espacios estigmatizados de la ciudad, con el riesgo de ser señalados como transgresores cuando traspasan los bordes simbólicos del Quito moderno. Ocurrió con los pueblos indígenas y afroquiteños que levantaron sus protestas y demandas en los contornos comunales y barriales, en una suerte de microespacios en los que se incuba un bizarro racismo cultural, muestra de la persistente colonialidad del no lugar en la ciudad metropolitana.

Las organizaciones sindicales y los gremios públicos, cuando protagonizaron manifestaciones por sus demandas laborales, lo hicieron dentro de un perímetro simbólicamente delimitado que empieza en el centro norte, en la Caja del Seguro, recorren las mismas calles hasta arribar a alguna de las plazas del Centro Histórico, asumido como el lugar emblemático de las concentraciones obreras y populares. El movimiento indígena, en sus distintas tomas y entradas a la ciudad, convirtió en sitio simbólico de la presencia indígena al parque El Arbolito, igual en el centro norte, transformado ocasionalmente con la presencia de los pueblos indígenas en campamento, en centro logístico de las marchas y en ágora de sus deliberaciones.

Las clases acomodadas y estratos medios quiteños, en cambio, tendieron a expresarse con marchas y concentraciones en defensa de la capitalidad y en oposición al "mal gobierno", en un amplio espacio público de la ciudad moderna que es valorado simbólicamente como continuidad de lo privado. Es el parque La Carolina y sus avenidas circundantes que confieren estatus social a las marchas que ahí llegan o empiezan, del mismo modo que provoca la ilusión de subir de estatus, 
a las gentes de los barrios populares que cruzan la ciudad para recrearse allí (Naranjo 1999). Asimismo, en el curso de dichos años, el Centro Histórico quiteño se ratificó como el mayor espacio público de expresión política de la ciudad, no solo por estar ahí localizadas las sedes de los gobiernos nacional y municipal, sino cuando en sus plazas y calles convergieron las distintas movilizaciones sociales de las clases acomodadas, de los estratos medios y de los sectores populares en determinadas coyunturas de alta activación política.

En el fragmentado espacio público del distrito metropolitano se afirmaron las disímiles realidades barriales, las desiguales intervenciones municipales de hábitat y las contradictorias existencias culturales de su población. Las condiciones materiales de vida en la ciudad que devienen en detonantes de las movilizaciones sociales de conformidad y apego al orden, o de disconformidad con la política urbana, fueron y son diferentes entre los barrios patricios bien equipados y los barrios populares y periféricos mal integrados a la urbe; entre los barrios antiguos en decadencia y los nuevos barrios cerrados que se expanden sobre las comunas indígenas circundantes; entre el crecimiento en altura en áreas exclusivas de renovación urbana y el crecimiento horizontal de masividad habitacional; entre las comunas, anejos y poblados rurales, y los agentes inmobiliarios y económicos del crecimiento urbano.

Los sentidos culturales de los espacios públicos en el distrito metropolitano traslucen que la ciudad es al mismo tiempo el lugar de realización de la acumulación e individualización capitalista, de la democratización urbana promovida por gobiernos municipales que se pretenden cercanos a la gente, y del conjunto de luchas populares urbanas que potencialmente van más allá de las demandas inmediatistas de las organizaciones barriales, con fugaces resplandores emancipadores del territorio y la ciudad.

Las luchas sociales acaecidas en el fraccionado espacio público capitalino denotan que las expectativas de contar con movimientos urbanos antisistémicos, o con una "sociedad civil" que demande y ejerza los derechos ciudadanos, eran, en el período en estudio, un anhelo todavía incierto, cuya argumentación pervivía en el ámbito de las teorías 
emancipatorias, porque en la praxis urbana, donde se concreta la existencia social, prevaleció más bien una tendencia a la segmentación de los habitantes como requerimiento de las políticas públicas urbanas.

La distinción entre el uniforme discurso de ciudadanía que alude a la sociedad civil y los fragmentados discursos de población para fines de implementar las políticas públicas se ensambla precariamente, se requiere tanto de la individualidad ciudadana con la que se forma una subjetividad homogénea de adscripción a la ciudad cuanto de la segmentación de sus habitantes en estratos de poblaciones diferenciadas conforme a las intervenciones estatales.

En la práctica el ensamble discursivo de ciudadanía y población no es fluido, por el contrario, conlleva conflictos en torno a las prioridades públicas, a los imaginarios urbanos contradictorios y a los desconciertos de identidad. Las desiguales acciones públicas de ciudadanía y población evidencian la contradicción entre la planificación urbana y su mundana gestión que se materializa en hábitats segregados: unos uniformes y bien atendidos acordes con la individualidad ciudadana, y otros precarios e insuficientemente atendidos en correspondencia con la segmentación de la población. Sin duda, también las mixturas discursivas de sociedad civil y población forman parte de las subjetividades emergentes difuminadas en la ciudad.

En los espacios públicos capitalinos se rebelan los antagonismos de la política urbana, generadora de las áreas consolidadas del centro norte y los valles centro-orientales, en las que se concentra la riqueza material y la calidad de vida, y de las áreas no consolidadas en las que se imbrica la diversidad cultural con la inequidad y la pobreza, como ocurre en los barrios de los extremos urbanos del sur, del norte y en la mayoría de las parroquias rurales. En los espacios públicos se expresan, igualmente, las tensiones entre las organizaciones sociales que proliferan en los ámbitos de la sociedad civil y las del amplio campo poblacional urbano en constante readecuación en la ciudad, con lo que en los fragmentados espacios públicos capitalinos también se proyecta el beligerante avance de la homogeneidad urbana, expresión de una de- 
seada unificación nacional, como diría Chatterjee (2008), en tiempos de discordantes condiciones de heterogeneidad social.

\section{Subjetividades barriales compartidas}

La trayectoria de las organizaciones barriales quiteñas revela que hubo distintas subjetividades urbanas compartidas por sus actores. En la conformación del sujeto barrial quiteño, conviene considerar que este no fue ni es ajeno a las tensiones culturales derivadas de los afanes de modernidad de la ciudad, más bien emergió como la combinación endémica de impulsos clientelares generados por las autoridades municipales, junto con impulsos asociativos por la inclusión de los moradores y barrios periféricos en el progreso de la ciudad. Sus organizaciones se formaron en los híbridos entornos sociales de los habitantes de los barrios periféricos, influenciadas, ciertamente, por las expectativas de interacción capitalina.

En medio del discurso de la sociedad civil, del clientelismo de los notables barriales y de la segmentación poblacional de la política urbana, el movimiento barrial no supo contener, encarnar o abarcar suficientemente los intereses del diverso campo de lo popular urbano. Se circunscribió a las luchas por tierra, vivienda y equipamiento en los barrios periféricos, disociando el pragmatismo de las demandas barriales, de los antagonismos y la diversidad cultural de sus pobladores, especialmente en las organizaciones provivienda que se mostraron rígidas en sus propósitos, excluyentes en las membrecías y distantes de otras asociatividades urbanas.

Desde mediados de los años 70, en el ámbito barrial capitalino, se evidenció una dislocación entre la retórica inmediatista de las dirigencias barriales y la perspectiva de los aliados políticos en pos de un movimiento popular urbano. No fue solo una disfuncionalidad entre las ilusiones movimentistas de los actores de la izquierda política capitalina y el realismo organizativo popular, sino también, en parte, las derivas ideológicas del ciclo de despegue, crecimiento y repliegue que experimentaron las organizaciones barriales. En el movimiento barrial capitalino se eslabonaron tres subjetividades colectivas: surgió en torno 
a lo vecinal, se amplió hacia la diversidad poblacional y se dispersó en la ciudadanía.

Las tres narrativas cohesionaron cada uno de los distintos momentos del ciclo del movimiento barrial — que analizaré más adelante- y se enlazaron con valores de la idiosincrasia quiteña, empalmando simbolismos de rebeldía popular con jerárquicos estilos de vida urbana. Se trata de un molde cultural de linaje colonial en el que coexisten imágenes contradictorias de un lejano pasado de levantamientos barriales y de una ciudad "pacífica y conventual" que no encajaron con las movilizaciones barriales del período, pero que se usaron como conectores simbólicos que alegan una continuidad de rebeliones en las luchas barriales.

Las subjetividades colectivas vecinal, poblacional y ciudadana hicieron suyo el simbolismo barrial de "rebeldía pacífica" que pervive en la memoria de los barrios quiteños y se proyecta, episódicamente, en las reservas morales de sus habitantes, impeliéndoles, en coyunturas de malestar público, a blandir banderas y proclamas de subversión ciudadana. A más de ser una señal del desencaje entre las expectativas izquierdistas de alineaciones populares y el pragmatismo organizativo barrial, la retórica de rebeldía pacífica ha sido una "patente de corso" o potestad heredada del pueblo quiteño para las movilizaciones callejeras.

En tanto conector cultural, la retórica de rebeldía barrial y paz conventual enlaza referencias de acontecimientos históricos del pasado de la ciudad con las movilizaciones contemporáneas, juntando una artificiosa secuencia de imaginarios urbanos enraizados en hechos sociales distantes y distintos. En las sucesivas incursiones que realicé con varios comités y federaciones barriales, así como en la participación en las reuniones del Consejo Metropolitano de Planificación y en las más recientes reuniones en el Foro de la Ciudad, ha sido frecuente constatar que subsisten reminiscencias y brumosas alegorías de las rebeliones quiteñas, de sus personajes y eventos, las que todavía son usadas indistintamente en los discursos cívicos. Entre otras, escuchar las frases del estilo: "Recuerden que Quito es luz de América, por eso somos libertarios", "Los barrios quiteños nos levantamos en las alcabalas y luchamos con el marqués de Selva Alegre” o "Los barrios populares combatimos junto 
a Eloy Alfaro", suelen ornamentar las proclamas de los exponentes de la sociedad civil y de algunos dirigentes barriales capitalinos.

Según el historiador Juan Paz y Miño sí fueron frecuentes los levantamientos de la población mestiza en las urbes durante la época colonial $(2014,29)$. Las alusiones contemporáneas se refieren a los episodios quiteños de la temprana Rebelión de los encomenderos entre 15441546, contra las leyes de encomienda y el trabajo indígena que mostró las pugnas por el poder local entre conquistadores y autoridades de la Corona; a la Revolución de las alcabalas que opuso a los comerciantes y la población quiteña contra los impuestos al comercio en 1592-1594; a la Rebelión de los barrios de Quito en contra de los estancos de aguardiente y el cobro de aduanas en 1765; y a la Revolución de Quito en 1809 con la que se inició el ciclo nacionalista y autonomista por la Independencia ecuatoriana (29-52).

Los hitos históricos de las rebeliones quiteñas forman parte de la oratoria patriótica capitalina que, ritualmente, se ratifica en los principales eventos celebrativos públicos, pues la retórica y simbología municipal los recrea como elementos cívicos de la ciudad y del espíritu de rebeldía de sus habitantes. Los hitos están en las crónicas oficiales de la ciudad, en los museos que recrean acontecimientos históricos y exhiben reliquias personales y familiares de sus participantes, constan en la oratoria de los centros educativos municipales y se rehacen en las alegorías patrióticas de la ciudad.

A manera de contrapeso, el ícono de rebelión barrial es relativizada con la imagen de una urbe sosegada por el aura de "paz franciscana", derivada de la deidad católica de san Francisco a la que fue encomendada la ciudad desde su fundación, que igualmente se afirma en la ritualidad pública, en la retórica celebrativa y en algunos de los imaginarios urbanos.

Detrás de la retórica de "paz franciscana” se esboza el complejo de inferioridad colonial. La supuesta calma citadina está enraizada en la mirada foránea de la ciudad del siglo XIX, que caracterizaba a Quito como una ciudad retraída en el pasado, en comparación con las urbes europeas, y escondía su pertinencia en el proceso histórico de conformación del Estado-nación ecuatoriano. La visión europea de las ciudades 
andinas expresaba la exterioridad cultural con la que se caracterizaba a las urbes locales, considerándolas, en comparación a las urbes europeas, como cuasi ciudades, apenas conformadas por espacios semivacíos y carentes de memorias propias, pues como señaló Said $(1990,35)$ en el siglo XIX el imaginario occidental urbano todavía se pretendía superior a cualquier otro imaginario urbano no occidental.

En las crónicas recogidas por Peyronnie y Maximy (2002), un académico ecuatoriano describía Quito a mediados del siglo XIX como una ciudad "tranquila, pasiva, patriarcal, reducida a sí misma, ignorante, sin vida, sin comunicación”, aislada de Europa, cuyas gentes desconocen los grandes acontecimientos externos porque es "gobernada por el oscurantismo de los monjes"; visión que fue ratificada por el embajador de Estados Unidos en Quito, quien en 1861 señaló que el peso económico y cultural de las iglesias, conventos y monasterios impidió, desde tiempo atrás, que la ciudad ocupe "un lugar de excepción entre las naciones civilizadas" (16-7).

La visión colonial de la ciudad no es solo una perspectiva del pasado. ${ }^{4}$ Hay crónicas de viajeros europeos que menosprecian la ciudad andina hasta casi la mitad del siglo XX; incluso los propios autores del estudio sobre Quito y su Centro Histórico (21) reconocen que, aunque la sociedad quiteña ha cambiado mucho, "el aislamiento al que están condenadas las ciudades de la Sierra y su población” hacen que a finales del siglo XX todavía se encuentren muchos "actos de sociedad y de comportamiento" que no están tan distantes de los "razonamientos de costumbres y de política que los suscitan".

En cada uno de los períodos del movimiento barrial y sus respectivas narrativas vecinal, poblacional y ciudadana, se reproducen los solapamientos retóricos entre las reminiscencias de las rebeliones barriales

4 Las diversas crónicas de los visitantes en el siglo XIX comparten la visión de Quito como una ciudad atrasada, en aislamiento y conventual, tanto en su forma física como en el comportamiento de su gente, asemejándola a las "pequeñas urbes europeas de tercer orden"; si bien son visiones que conllevan un sesgo anticlerical, en lo sustantivo desconocen los procesos y contextos territoriales, políticos y culturales propios de configuración de las urbes andinas y sus roles en la constitución de los Estados-nación. Sobre el tema ver Kingman y Bedón (2014, 27-42). 
y las alusiones a la paz franciscana de Quito, deviniendo en una ideología de lo barrial que naturaliza la explicación de los comportamientos culturales y políticos de sus habitantes, reduciéndolos a una idiosincrasia callejera propia del retraimiento andino. Desconoce el complejo entramado de relacionamientos de poder entre las clases sociales urbanas, los encontrados intereses espaciales en las disputas públicas y privadas y las jerárquicas tensiones entre actores sociales en condiciones material y culturalmente desiguales, y atribuye, llanamente, un supuesto carácter volcánico, impredecible, a los barrios y habitantes de la capital.

Asumida idiosincráticamente en amplios círculos capitalinos, la retórica de la "rebeldía pacífica" es usada como advertencia del potencial reactivo de los barrios quiteños, especialmente en determinadas coyunturas de descontento político que han estimulado escaladas de malestar ciudadano, como lo expresan las palabras del exalcalde de la ciudad Paco Moncayo que al respecto dijo lo siguiente:

Yo creo que esta ciudad es en gran forma progresista, pero también somos los quiteños noveleros, no hay "ismo" que no haya habido en Europa que no haya habido en Quito, y esto es histórico. Los quiteños somos noveleros y eso afecta de alguna manera, porque nos encanta el outsider, pero no nos gusta la continuidad, nos asusta la rutina, nos gusta cambiar, somos así desde que nacimos como ciudad. Creo que la ciudad tiene estos valores y estas características que no se borran, que vienen construyéndose. (2015, entrevista personal)

La "novelería quiteña", a la que alude el burgomaestre, es una suerte de sentido común que nombra, atribuye, un rasgo cultural que es de pocos como si fuera una condición identitaria de todos, recurriendo a iconografías que circulan cotidianamente como parte de la idiosincrasia de la ciudad y que afirman, en el imaginario público, el protagonismo ilustrado de los notables y próceres de las élites quiteñas, mientras el carácter insurgente de los mismos hechos históricos se disuelven en lo impersonal de lo barrial.

La analogía de paz franciscana, haciendo suyo el complejo de inferioridad colonial, corrobora que los alzamientos barriales solo ocurren ante graves crisis nacionales, asumiendo que en la cotidianidad de 
la vida capitalina predomina la tranquila convivencia de sus habitantes, en la que la discriminación racial, el prejuicio ante la diferencia cultural y la exclusión derivada de la pobreza se asumen como propias de la segregación urbana. En esta visión se admite que Quito es una ciudad apacible, que sus barrios se prestan a una tranquila coexistencia, pero cuando por razones del "mal gobierno" se condensan las crisis políticas que alteran sus pacíficas costumbres, se activan los dispositivos simbólicos que movilizan a los barrios para restaurar la calma y el funcionamiento "normal" de la sociedad quiteña.

Algo similar ocurría con la visión generalizada de que las experiencias de los primeros comités de adelanto o promejoras de los antiguos barrios del centro de Quito, con su costumbrismo, hazañas y personajes mestizos, se proyectaban en todas las demás organizaciones barriales de la ciudad como si fuesen el cimiento de una misma identidad barrial compartida y aceptada entre todas las organizaciones populares urbanas. Con este propósito y declarándose "no regionalista", se fundó en 1950 la Sociedad Unión de Quiteños y Amigos de Quito que buscaba luchar por las virtudes y tradiciones quiteñas mediante el trabajo con organizaciones barriales y colonias provinciales, asumiendo que el costumbrismo quiteño era parte del sentimiento de ecuatorianismo que aportará a la solución de los problemas nacionales (D. G. n. ${ }^{\circ} 687$ 1960).

La imagen de rebeldía pacífica estuvo principalmente relacionada con la vida social y cultural en los barrios del Centro Histórico de la ciudad, los que delimitaban el perímetro urbano hasta fines de los años 40 del siglo XX, cuando se inició el proceso metropolitano de Quito. La antigua ciudad, hoy el Centro Histórico, dejó de ser el núcleo organizador del territorio. Los comités barriales del centro fueron desplazados como eje del movimiento popular urbano, por el surgimiento de nuevos barrios y organizaciones poblacionales, hasta que en los años 60 se extinguieron como referentes de la movilización barrial. No obstante, la nostalgia de las proezas de rebeldía barrial acaecidas en la vieja ciudad subsistieron, en las siguientes décadas, entrelazadas en las alegorías discursivas con que las dirigencias barriales argumentaban las convocatorias a las luchas por la vivienda, servicios, legalización de tierras y barrios. 
Más allá del anecdotario heroico de los barrios del centro de la ciudad que hace las veces de antecedente remoto de las luchas barriales quiteñas, es un hecho cierto que a partir de la segunda mitad del siglo $\mathrm{XX}$ el aumento de las organizaciones del amplio espectro de sujetos, actores y acciones que conforman el campo de lo popular urbano, grosso modo han sido concomitantes con las tendencias del crecimiento metropolitano que trajo aparejado el surgimiento de nuevos barrios periféricos, el incremento de la población urbana, la diversificación de las expectativas de vida y nuevas experiencias colectivas para resolver las carencias materiales en la ciudad.

Las movilizaciones barriales se desplegaron entrelazadas con las subjetividades colectivas: lo vecinal en conexión con el pasado aristocrático de la urbe, lo poblacional vinculado a la creciente diversidad social con el tránsito metropolitano, y la ciudadanía a la individualidad de los derechos sociales en la modernidad urbana. No han sido demarcaciones ideológicas excluyentes ni realidades urbanas contrapuestas, sino momentos diferenciados del movimiento barrial capitalino de desplazamientos entre la contestación y la emulación del orden. Aunque adquirieron, de modo sucesivo, un sentido enunciativo diferenciador del sujeto popular urbano, conforme las transformaciones contemporáneas de la sociedad quiteña no lograron, cada una ni en conjunto, consolidarse como un discurso de interpelación del poder local y la segregación urbana.

\section{La levedad de lo barrial}

El surgimiento de un movimiento social asentado en los barrios periféricos requiere una reflexión, al menos referencial, de las relaciones culturales entre los barrios populares y la ciudad, de las expectativas de sus habitantes respecto de la vida urbana; precisa de una mirada al carácter relativo de lo barrial en la configuración de la ciudad, que permita dimensionar la escala cultural de los barrios periféricos respecto de la totalidad urbana. Por su condición periférica, los barrios populares devienen en un tipo de unidades espaciales menores subordinadas y sometidas al proceso urbano, dentro de las cuales se reproduce la dinámica de orden y poder de la ciudad. 
Sobre esta temática existe una amplia bibliografía académica, de la que interesa señalar el enfoque de Henri Lefebvre (1978) quien, distanciándose de lo que denomina la "ideología de lo barrial", devenida en una confusa apología de lo descriptivo y lo normativo que esencializa al barrio como organizador natural de la vida urbana, definió a los barrios como formas de organización temporales y espaciales de la ciudad, a manera de continuidades del pasado en la vieja ciudad colonial, configurada con el entramado de calles y barrios, y como tal, asiento de las viviendas y escenario de la reproducción social de la población. En los barrios, dice el filósofo y sociólogo francés, predominan las formas básicas de sociabilidad espontánea, derivadas de la vecindad, por lo que, en tanto materializaciones de lo urbano, los barrios son importantes pero no esenciales, más coyunturales que estructurales (200).

En los barrios no se forman ni instituyen los principales roles sociales ni las conductas o los comportamientos comunes, ni siquiera cuando utilizan la territorialidad para imponerse, pues según el autor el barrio no interviene en la creación de valores dominantes y prácticas fundacionales de ciudadanía; estas se generan en otros ámbitos e instituciones urbanas como la educación y la escolaridad, la economía y el mercado, el Estado y la política, el poder y la sociedad; y si bien pueden darse condiciones políticas y culturales para que en los barrios emerjan efervescencias de luchas poblacionales, las instituciones fundantes no tienen nada en común con los barrios, contrariamente, los desbordan, los dominan (197-200).

Los barrios populares como espacios sociales mínimos configurados incompletamente por las instituciones y los núcleos urbanos tienen existencias transitorias, aunque en su interior se constituyen relaciones interpersonales más o menos duraderas y profundas, "es el más grande de los pequeños grupos sociales y el más pequeño de los grandes” (200), donde la cercanía sustituye las distancias sociales, espaciales y temporales.

Los barrios tampoco son unidades autosuficientes, dependen de otros grupos funcionales más amplios que están activos a escala de la ciudad, la región y el país con los cuales se accede a bienes, servicios, ingresos y se configuran las identidades, con lo que en palabras de Lefebvre: "La estructura del barrio depende completamente de otras es- 
tructuras más vastas: municipalidades, poder político, instituciones. No es más que una ínfima malla del tejido urbano y de la red que constituye los espacios sociales de la ciudad" (202).

La relatividad espacial de lo barrial se expresa en los vínculos de cercanía que devienen suplementarios respecto de las relaciones productivas, comerciales, de movilidad y culturales que tejen los habitantes populares de la ciudad, las que suelen ser de mayor dependencia y duraderas. Si bien los barrios periféricos son parte del ecosistema social de la ciudad basado en el ethos del pueblo, como tal integran el campo de lo popular urbano, están sometidos a los rápidos cambios de la urbe que alteran las simetrías habituales entre moradores, sus redes familiares y de afinidad, las dirigencias y organizaciones, creándose condiciones territoriales que involucran a los habitantes en un "continuo y rápido movimiento que transforma los barrios en criaturas híbridas suspendidas entre el pasado y el futuro", dice Suzanne Keller $(1975,30)$.

En Quito el carácter relativo de lo barrial está en la base social y espacial del movimiento barrial, cuya existencia se correlaciona con la temporalidad de los barrios periféricos surgidos en gran número como lotizaciones, cooperativas y asentamientos humanos en los márgenes de la ciudad, inicialmente inducidos por agentes inmobiliarios y traficantes de tierras que luego, por medio de autogestión vecinal o comunitaria, de parciales y clientelares intervenciones municipales, y de ocasionales ayudas prestadas por entidades de la sociedad civil, devienen en precarios barrios periféricos en situación de irregularidad.

Las identidades de sus moradores son igualmente transitorias, se muestran más consistentes en los momentos iniciales del asentamiento, asumiendo formas de resistencia e incluso de rechazo a la ciudad, valorizando las identidades de origen, luego con la formación del barrio se negocian las nuevas identidades urbanas, hasta mutar en sujetos representativos del mundo popular urbano, convirtiéndose en "partícipes de una modernidad y una ciudadanía que cuesta pero seduce”, concluyen Ortiz y Martínez refiriéndose, por ejemplo, a la experiencia de formación del barrio La Argelia (1999, 349), aunque su afirmación es extensible a los barrios periféricos capitalinos. 
No es extraño que un indicador de la relatividad de lo barrial sea la expectativa, generalizada en muchos de los habitantes de los barrios periféricos quiteños, de que si tuvieran los recursos económicos suficientes se mudarían a otros que presten mejores condiciones de vida, aunque los barrios en los que habitan se encuentren consolidados (Peyronnie 2000). Mudarse del barrio periférico o popular, lugar de residencia habitual, a otro que preste mejores condiciones de habitabilidad, al tiempo que confiere mayor estatus social, forma parte de las expectativas de progreso compartidas por muchas personas en los barrios periféricos quiteños. La transitoriedad barrial y la expectativa de movilidad de sus habitantes están en la base de los cambios que experimentaron las organizaciones barriales, e imbricadas con los énfasis discursivos que contribuyeron al fraccionamiento simbólico del espacio público.

La relatividad de los barrios quiteños se evidencia también en el alcance de las modificaciones del hábitat popular, respecto de los estándares de habitabilidad de los barrios bien atendidos en la ciudad. Vistos en un arco temporal de ocho décadas, desde los años 40 del siglo XX hasta la segunda década de los años 2000 del siglo XXI, los barrios periféricos empezaron como asentamientos irregulares sin reconocimiento legal ni servicios, abandonados a la suerte de sus habitantes, quienes tras largas presiones lograron, en algunos casos, su regularización, obteniendo reconocimiento jurídico y acceso a infraestructura, servicios y equipamiento para transformarse en barrios periféricos, los que finalmente, en el marco de la democratización de la ciudad, devendrían en barrios populares.

En el largo y conflictivo proceso de integración de los barrios periféricos a la ciudad, en los que más del $70 \%$ de las viviendas son autoconstruidas, lo que sin duda significa un enorme esfuerzo colectivo por dotarse de vivienda digna en condiciones adversas, persisten o se agudizan congénitas situaciones de inseguridad y violencia social, precariedad en la movilidad y el acceso debido a las largas distancias y el mal servicio de transporte, de insalubridad junto con un inadecuado manejo de los desechos sólidos y, en general, de deficitarias condiciones de vida. Los asentamientos irregulares nacieron desdeñados de la 
vida y la centralidad capitalina, en una suerte de reductos territoriales de la pobreza urbana, donde con esfuerzos propios se configuran hábitats populares, sin embargo de lo cual, y más allá de las intervenciones municipales para extender los servicios básicos, se tiende a reproducir la segregación urbana.

\section{El ciclo del movimiento barrial quiteño}

El movimiento barrial quiteño no siguió un curso uniforme de expansión socioorganizativa conforme el crecimiento de los barrios periféricos, ni hubo un determinismo mecanicista de la expansión urbana en el incremento organizativo que agregue los intereses barriales. Considerando el reciente proceso de formación de los asentamientos humanos irregulares en las tierras residuales del mercado inmobiliario quiteño, se puede afirmar que el movimiento barrial capitalino experimentó una trayectoria cíclica de inicio, auge y dispersión, provocada por múltiples factores, entre los cuales están el mercado informal de tierras, el clientelismo político y municipal, las influencias de los agentes de desarrollo, las iniciativas organizativas de los pobladores y sus encuentros en los espacios públicos con otros sectores populares. La trayectoria organizativa barrial no estuvo exenta de tensiones, de episodios de movilización colectiva y de repliegues reivindicativos.

Su comprensión supone una mirada al itinerario seguido por el movimiento barrial y el incremento de las luchas urbanas, lo que entraña una periodización de su trayectoria para advertir cómo ocurrió el declive organizativo después de un período de auge en la movilización, eventos que, a su vez, demandan el discernimiento de los orígenes, continuidades y rupturas en la lucha barrial de Quito. Al respecto, cabe señalar que el interés académico en explicar el movimentismo barrial del país es incipiente, el tema está casi ausente en los estudios urbanos, salvo contados trabajos de los años 80 sobre las organizaciones provivienda de Quito, la preocupación por el análisis del movimiento y las organizaciones barriales es mínima en la agenda de investigación urbana.

En una reciente síntesis sobre la investigación urbana Bermúdez y otros autores declaran que es "artificioso" el inventario y clasificación 
de las temáticas urbanas y su evolución. En la taxonomía adoptada se evidencia el carácter accesorio que se atribuye a las luchas populares urbanas, apenas son mencionadas parcialmente en la temática de lo "urbano y los enfoques de historia social", como un aspecto menor de las “dinámicas de segregación urbana”, e indirectamente en lo concerniente a la "gestión urbana" con la descentralización como posibilidad democratizadora (2016).

El balance analítico, sin duda un valioso esfuerzo de síntesis de los estudios urbanos ecuatorianos, revela los sesgos disciplinares e institucionales de sus autores: el "crecimiento urbano" se enfoca en la planificación y la normativa, no en los barrios periféricos; los "centros históricos" en el monumentalismo de las estructuras edificadas y no en sus ocupantes; la "economía urbana” en la evolución del mercado del suelo y no en el trabajo de la gente; el "medioambiente urbano" en los vectores contaminantes, la gestión de riesgos y el cambio climático, y no en los conflictos socioambientales.

Nada se dice de los estudios sobre la negritud y afrodescendencia en Quito, acerca de los indígenas en la ciudad, las juventudes e identidades urbanas, menos aún de las mujeres y sus demandas de vida, las olas de migraciones y el fenómeno de los retornados, sobre la participación ciudadana, las iniciativas barriales de hábitat popular, entre otros temas que cuentan con sendas investigaciones y publicaciones. El balance desconoce el subcampo social y cultural de los estudios urbanos, por lo que da una sensación de parcialidad temática, o tal vez se está reeditando, no muy artificiosamente, la colonial visión de lo urbano como mercado, estructuras y gestión, relegando a sus habitantes, conflictos y luchas.

En una exploración precursora Mario Unda (2008) propuso una periodización del movimiento barrial de Quito, a partir de la combinación de lo que denominó "seis procesos co-constituyentes y yuxtapuestos” como los procesos económicos nacionales y locales, las dinámicas del sistema político, las modificaciones de la organización territorial, las dinámicas de las luchas sociales y del movimiento popular, las dinámicas propias del movimiento barrial y las dinámicas sociales en los barrios. El autor establece períodos con fronteras referenciales que se "difuminan 
cuando un período termina y da paso al siguiente", mediante fases en las que el movimiento vecinal se integra según su conformación social, en el relacionamiento entre los diversos sectores populares, en su vinculación al sistema político y su inserción en la organización territorial (9).

La periodización de Unda abarca una curva temporal de más de ochenta años. Arranca en los años 30 del siglo XX y llega hasta el año 2008, estableciendo tres períodos claros y eventualmente uno nuevo, en los que predominan las tendencias organizativas y de movilización social caracterizadas por la relación diferenciada del movimiento barrial con el sistema político; entre los períodos se intercalan tres fases de transición en las que las dinámicas organizativas se agotan y dan paso a nuevas, las que están en referencia al incremento de los barrios populares y su inserción en la organización territorial (11).

La distinción entre períodos constitutivos y fases de transición en la periodización del movimiento barrial quiteño es pertinente, para lo cual Unda actualizó su interpretación planteada anteriormente (1996) sobre el crecimiento organizativo barrial. No obstante, en su estudio, paradójicamente, se vuelve porosa, se difumina, la distinción entre períodos y fases, al establecer las fases de transición por fuera de los períodos y no como intervalos que los empalmen desde adentro, dándose situaciones de fases más complejas, extensas y decisivas que algunos de los períodos, con lo que ambos, períodos y fases, devienen, por igual, en una suerte de siete momentos en el ciclo del movimiento barrial.

En Quito la expansión urbana y el desarrollo del movimiento barrial no siguieron una trayectoria paralela. La evolución organizativa no dependió exclusivamente del crecimiento de la ciudad, sino que, en el contexto estructural de una tendencia a la continua y desbordada expansión urbana metropolitana, intensificada en determinadas coyunturas nacionales de bonanza económica, el movimiento barrial capitalino experimentó una tendencia discontinua en su organización, movilizaciones y reivindicaciones.

A la inicial conformación de comités barriales le siguió el auge de las luchas poblacionales y más tarde el reflujo del movimiento barrial, siempre en medio de una continua expansión urbana. El movimiento 
barrial quiteño experimentó una ola organizativa y de luchas urbanas que, analíticamente, puede verse como parte de la tendencia cíclica de los movimientos sociales, pudiendo sí establecerse correlaciones entre la expansión urbana y la dinámica del movimiento barrial, pero sus nexos no son mecánicos, ni obedecen a una lógica determinista de la organización territorial sobre la organización barrial, aunque prevalezca el sentido pragmático que motivó la asociatividad viviendista.

No es que el urbanismo o el ordenamiento territorial reglen las formas de organización social, ni que necesariamente a una mayor expansión urbana le corresponde un aumento del movimiento barrial. Se trata más bien de la relación inacabada, incompleta, de la ciudad con sus barrios, en la que no hay una totalidad sistémica que module sus demandas, sino la continua segregación de la política urbana que provoca reacciones difusas y adaptaciones colectivas.

El movimiento barrial se configuró en las fisuras de la expansión urbana metropolitana. Las primeras organizaciones barriales surgieron en el marco de la congénita segregación norte sur, posteriormente las luchas barriales crecieron conforme se discriminaba a los nuevos asentamientos pericentrales y valles circundantes, hasta que sucedió el repliegue de las luchas barriales, pese al continuo crecimiento de los barrios periféricos y la persistencia de la segregación urbana.

Si los barrios no son formaciones naturales de la ciudad, sino texturas urbanísticas emergidas del solapamiento de factores espaciales, económicos y políticos, las organizaciones barriales tampoco son brotes espontáneos de la sociedad, sino constructos culturales intencionados de los habitantes, vigentes por su utilidad para la inserción espacial en la ciudad. El protagonismo transitorio de las organizaciones barriales en los espacios públicos de la ciudad se debe a la mencionada levedad de lo barrial, a la racionalidad instrumental en la formación de las organizaciones y al encuentro temporal con aliados políticos y agentes inductores de la acción colectiva.

En el encuentro en los espacios públicos de las organizaciones barriales con los agentes políticos, fue decisivo el rol difusor de los alcaldes de la ciudad que, ya desde los años 50 del siglo XX, promovieron 
la formación de los primeros comités promejoras; posteriormente, las entidades estatales que indujeron organizaciones como condición para el acceso a los bienes y servicios públicos; y más tarde los partidos políticos que en los barrios superpusieron comités partidarios como parte de las maquinarias electorales. Igualmente, la presencia de las comunidades eclesiales de base (CEB), la militancia de izquierda, las entidades de la cooperación internacional y las organizaciones no gubernamentales promovieron formas asociativas de gestión urbana.

Fueron cruciales las propias iniciativas de los habitantes de los barrios periféricos en la autogestión de servicios, especialmente en condiciones de persistencia de matrices culturales de reciprocidad en la población rural que migró a la ciudad y pobló los barrios periféricos, y de los arrendatarios empobrecidos que se trasladaron desde los tugurios del centro, o de los antiguos barrios populares, a los nuevos barrios periféricos portando prácticas colaborativas de vecindad.

Sería voluntarismo pensar que estos agentes e iniciativas sociales se agruparon intencionadamente para promover la organización del sujeto barrial. Al contrario, los agentes desplegaron paralelos y especializados protocolos de intervención social con temporalidades y resultados disímiles, y aunque ocurrieron situaciones extraordinarias de convergencia de algunos de ellos, por lo regular, la organización barrial resultante fue consecuencia de intervenciones episódicas e incompletas. La importancia de los agentes no fue siempre la misma, varió según los impactos de las coyunturas políticas nacionales que estimularon o restringieron la intensidad de los procesos organizativos, los cuales también, internamente, se potenciaron o desincentivaron conforme los valores de la cultura política capitalina, especialmente de la cercanía de los liderazgos barriales con las prácticas autoritarias y patrimoniales sobre los bienes comunes.

Concuerdo con Unda en que el movimiento barrial se constituyó en el contacto con otros sectores populares, en el relacionamiento con el sistema político y la estructura de la ciudad, lo cual fue posible debido a la concurrencia de los aliados que apoyaron los vínculos entre las organizaciones barriales, deportivas, juveniles, comerciales, artesanales 
y promovieron la formación de las federaciones barriales que amplificaron su lucha. El encuentro de las organizaciones barriales con sus diversos aliados cualificó al movimiento barrial proveyendo educación popular, medios de comunicación alternativos, capacitación organizativa, activismo y la energía cultural necesarias para animar las asambleas, reuniones, campañas, marchas, ocupaciones y demás formas de lucha.

De ahí que, en la caracterización de la ola expansiva del movimiento barrial quiteño, cabe considerar que su dinamismo estuvo relacionado con el encuentro, en los espacios públicos, con los aliados políticos, agentes inductores y otros movimientos populares que enriquecieron a la organización barrial, ampliaron sus repertorios de acción colectiva y promovieron la agregación de intereses que permitió la contestación política de los barrios periféricos a la política urbana. Asimismo, el posterior desencuentro entre los actores urbanos, agentes inductores y las organizaciones barriales fue indicativo del declive de las luchas barriales, pues en las organizaciones barriales perviven valores y prácticas de contingencia y transitoriedad, que entran en tensión cuando en las movilizaciones se cruzan las perspectivas políticas contestatarias de los aliados con el pragmatismo de sus dirigencias.

Coincido en que el movimiento barrial capitalino experimentó tres grandes períodos de formación, auge y declive, con la diferencia de que están eslabonados por fases internas de transición, esto es por lapsos acotados de aceleración-desaceleración de las luchas barriales que modificaron el alcance de las organizaciones, sus discursos y acciones.

El primer período empieza desde mediados de los años 40 y estuvo marcado por el estilo epistolar de la dirigencia barrial, con los primigenios comités de adelanto o promejoras marcados por el personalismo de sus dirigencias, la influencia clientelar de los tradicionales partidos políticos, mostrándose como instancias dependientes de los requerimientos de colaboración municipal, pues parecía que los comités promejoras se crearon para colaborar con la labor municipal de Quito (Últimas Noticias 1954). El período inicial se agotó y entró en una fase de transición, cuando el personalismo de la dirigencia barrial fue desplazado por la movilización popular a finales de los años 70, y prevale- 
ció el discurso vecinal como referencia subjetiva de adscripción barrial al orden aristocrático de la ciudad.

El segundo período comienza a inicios de la década de los años 80 con la expansión del movimiento poblacional, estimulado por la concurrencia de nuevos sectores sociales, organizaciones populares y agentes inductores en el contexto de la transición democrática y el aparecimiento de nuevos partidos políticos que disputaban el poder local; el período estuvo marcado, en cambio, por la activa movilización barrial ante el municipio hasta que llegó al pico más alto de organización y movilización urbana, que luego se desaceleró y entró en una nueva fase de transición con la pérdida de vigencia de las federaciones barriales, a finales de la década de los 90. En este período ocurrió el reemplazo discursivo de lo vecinal por lo poblacional, a manera de subjetividad compartida que disputó las demandas barriales en los espacios públicos.

El tercer período empieza en los años 2000 y se prolongará hasta finales de la siguiente década, con la generalización de una tendencia de reflujo del movimiento barrial, dispersión organizativa, desactivación de las federaciones y fragmentación de las demandas urbanas. El desmovilizado movimiento barrial se enredó con la política municipal de participación y se quedó al margen de las efervescentes movilizaciones de las clases medias y altas en defensa de la capitalidad. En el período ocurrió el relevo discursivo de lo poblacional por la ciudadanía, como subjetividad individual de emulación del orden en la urbe moderna. Veamos a continuación el ciclo del movimiento barrial quiteño, con sus períodos, fases de transición y subjetividades colectivas.

\section{Los inicios: El despegue organizativo vecinal}

En Quito, aunque hubo organizaciones sociales en épocas anteriores, lo que contemporáneamente se conoce como el movimiento barrial comenzó durante los años 40 del siglo XX, en el marco del pausado proceso de transición desde la ciudad hacendaria y tradicional a una urbe metropolitana en la que la sociedad capitalina experimentaba episódicas adaptaciones en la progresiva configuración de las clases, estamentos y grupos sociales modernos. 
En los años 40 la ciudad vivía lo que Ana María Goetschel denominó el "tránsito de una sociedad tradicional, de tipo patriarcal, en el que imperaba un sistema de castas a una sociedad más moderna” (1992, 319); fue un período en el que se condensaron y mezclaron, en torno al interés recíproco en el progreso de la ciudad, lo tradicional con lo moderno. Las antiguas formas de mediación y organización social de naturaleza corporativa de la ciudad como cofradías, gremios artesanales, gremios profesionales y círculos obreros católicos, dice Goetschel, daban paso a nuevas formas de socialización y mediación urbana con los clubes y ligas deportivas, juntas parroquiales y comités barriales (319).

El gradual tránsito a la modernización metropolitana de la ciudad se daba en condiciones de continuidad del control político de las élites quiteñas, tanto en la esfera pública con el municipio como en la esfera privada con el dominio de las principales instituciones sociales urbanas. En el ámbito barrial las iniciativas provenían de los alcaldes y sus planes de obras, se transmitían a los recién creados comités barriales, ligas deportivas y juntas parroquiales, en las que sus dirigentes replicaban los valores vecinales heredados de la ciudad nobiliaria.

Los primeros comités barriales estaban integrados por propietarios individuales de viviendas, eran una continuidad de las anteriores Juntas Pro mejoras, ${ }^{5}$ devenidas en Comités de Adelanto o Pro mejoras y posteriormente generalizados con la denominación de Comités Barriales (320). Se formaron al poco tiempo de fundados los primeros barrios periféricos, aledaños al centro de la ciudad y asentados en las laderas de escaso valor del suelo que estaban hacia el sur y cercanas al centro de la ciudad como La Colmena, Aguarico, La Tola, La Libertad, Toctiuco, San Juan y El Dorado (1992).

5 Recuérdese que, con esta figura y denominación generalizada en la nomenclatura institucional ecuatoriana, se crearon en el país no solo los comités barriales, sino también las primeras juntas de beneficencia, de artesanos, de regantes, de administraciones de agua, inclusive juntas más complejas como las de planificación, seguridad, vivienda, entre otras. La noción de “junta” es tributaria de una ambigua combinación de lenguajes públicos de origen securitista heredado de las dictaduras militares y de origen patrimonialista propio de las élites. 
Los barrios pericentrales de los años 40 empezaron sin canalización, agua potable, energía eléctrica y recolección de basura, con lo que sus habitantes, en creciente aumento, vivían en condiciones de insalubridad en las que se propagaban varias enfermedades contagiosas, pestes y epidemias, lo que presumiblemente les obligó a conformar los comités de adelanto o promejoras (1992), como entidades civiles jerárquicas y autorrepresentadas encargadas de conseguir en el municipio la infraestructura, los servicios y el equipamiento barrial necesarios.

Los comités de adelanto o promejoras también se formaron en los barrios populares del sur creados en los entornos de las pocas fábricas, bajo el precepto municipal de fundar "barrios obreros". Se fundó La Ferroviaria en la hacienda Chiriyacu de Monjas, comprada a una comunidad religiosa en 1947 por la Empresa de Ferrocarriles del Estado para construir una nueva estación, depósitos y viviendas de los empleados en la parte baja y proporcionar terrenos para cultivo a los empleados en la parte alta (Godard 1988, 54).

Asimismo, en tierras de antiguas haciendas se fundaron los barrios de Chimbacalle, Ciudadela México, Barrio Obrero, Chiriyacu, Alpahuasi y Villa Flora (Gomezjurado 2015, 434-40), bajo el influjo de las autoridades municipales, a su vez imbuidas de las ideas católicas de justicia social derivadas de la encíclica papal Rerum Novarum que había calado en algunos jóvenes de las familias aristocráticas capitalinas, entre ellos su primer alcalde Jacinto Jijón y Caamaño (Febres Cordero 2016, 105). Dado que en esos años en la ciudad la población obrera no era significativa, sino más bien la de artesanos y empleados, los barrios obreros progresivamente se transformaron en barrios de clase media porque fueron financiados y ocupados por funcionarios y afiliados de la Caja de Pensiones y la Caja del Seguro, como se denominaba en sus inicios a la seguridad social.

El mayor impulso a la formación de los comités barriales, y que generalizó su denominación, fue durante las administraciones municipales liberales en el lapso comprendido entre fines de los años 40 y mediados de los años 60, cuando los alcaldes liberales en un franco estilo populista visitaban los barrios de la ciudad para recabar sus necesida- 
des, y pedían a los moradores se organicen en comités para contribuir en la realización de las obras (Últimas Noticias 1954). Algunos comités tuvieron fugaz existencia, pues duraron solo el tiempo que requería la obra, y otros se mantuvieron como parte del armazón político-electoral del partido liberal para quien las juntas parroquiales, las ligas deportivas y los comités barriales constituían importantes mecanismos de su ejercicio político en la ciudad (Goetschel 1992).

Los comités barriales, conforme la cultura política heredada, estaban presididos por dirigentes que, distanciados de los moradores, conformaban un estamento autodelegado y en nombre de los barrios intermediaban en las relaciones con los notables, personalidades, políticos, autoridades locales, instituciones públicas y privadas de la ciudad. Los dirigentes barriales acostumbraban delegar el cumplimiento de las actividades entre los miembros de los comités, mediante la formación de "comisiones internas" que dedicaban la mayor parte de su tiempo a la preparación de las festividades cívicas, celebraciones religiosas y sucesivos eventos recreativos (Últimas Noticias 1957), y contrariamente menos tiempo a la gestión de las eventuales peticiones de infraestructura o equipamiento urbano.

Los comités de los barrios del centro se agruparon de modo inaugural en la Federación de Barrios y Ciudadelas del Cantón Quito, fundada en agosto de 1952 (Últimas Noticias 1952). Desde el inicio, la federación mantuvo una posición de anuencia ante las autoridades municipales y, aunque declaraba que se había formado para la defensa de los intereses de los barrios populares de la ciudad, recurría a una retórica cargada de exaltaciones propias del costumbrismo barrial en la que hacía suya la visión corporativa de "vecindad” (Últimas Noticias 1952), acuñada en los viejos barrios quiteños como identidad de la ciudad conventual.

La retórica quiteña de vecindad es de linaje colonial. Se remonta a una antigua práctica cultural de la gente blanco-mestiza que se autorreconocía entre sí por su procedencia familiar y residencial, cuando los descendientes de conquistadores y primeros pobladores forjaron una sociedad estamental en la que el origen y el prestigio social tenían importancia fundamental para la estructura y relaciones sociales, enrai- 
zadas en sólidas economías inmobiliarias y participación en el poder (Büschges 1999, 231). En la fundación de la ciudad se distribuyeron los principales solares "en consideración a la posición social de cada persona" (199), creando una estructura espacial de forma cuadricular concéntrica con edificios públicos, plazas, iglesias y conventos entre los que predominaban las "casas de las familias de la nobleza titulada” (200), que dieron origen a los primeros barrios quiteños. En adelante, la vida de la ciudad se configuró en torno a la vecindad de los barrios centrales, con el devenir del tiempo llamados tradicionales.

La vecindad como valor prescriptivo de cercanía espacial a los lugares de prestigio implicaba también una retórica de exaltación de los apellidos de origen hispano y el ocultamiento de los de progenie indígena, fraguándose una adscripción identitaria blanco-mestiza que pervive hasta la actualidad entre las clases medias y altas quiteñas, como símbolo de estatus y diferenciación social en el que el trato por los apellidos hispanos simboliza la cercanía, real o ficticia, al poder y prestigio.

En el siglo XIX la condición de ciudadano y vecino estaban solapadas en la vida municipal, explica Enrique Ayala refiriéndose a la elección de concejales: "Los electores eran los ciudadanos o los vecinos" $(2011,225)$, pues las normas ecuatorianas no habían resuelto esta distinción, con lo que en la práctica los electores eran "ciudadanos que además estaban avencindados en el municipio" (226), y revelaba las jerarquías de la ciudad en "la composición del municipio" (226). La vecindad devino intrínseca al simbolismo elitista de la representación municipal.

Entrados los años 40 y 50 del siglo XX la retórica de vecindad formaba parte de la cultura política quiteña. Se expresaba en el trato cotidiano entre notables, caciques y políticos liberales y conservadores que exhibían ante los moradores, dirigentes y comités barriales su cercanía con las autoridades de la ciudad y hacían gala de su familiaridad con el poder local. La Federación de Barrios y Ciudadelas del Cantón Quito emergió en un ambiente signado por el clientelismo y la retórica de vecindad en los comités barriales, interiorizó la adscripción vecinal y se declaraba la representante unificadora de los barrios quiteños, mezclando, en sus proclamas de defensa del interés barrial (Últimas Noticias 1952), las indi- 
viduales proezas de personajes y familias blanco-mestizas avencindadas en los barrios del centro como atributos icónicos de una identidad vecinal generalizada en todos los barrios periféricos capitalinos.

La federación, imbuida del espíritu filantrópico de las élites locales, se preocupaba de que las obras barriales contaran con la contribución del Club de Leones, procuraba la presencia honorífica del alcalde que realzaba las fiestas de fundación de los barrios y promovía que algunos de los notables de la ciudad se relacionen con los eventos cívicos de los barrios (Últimas Noticias 1953). La dirigencia de la federación exhibía en los habitantes de los barrios populares su cercanía simbólica a los notables y a las autoridades de la ciudad.

Desde el comienzo y durante su primera trayectoria en dos décadas, la Federación de Barrios y Ciudadelas del Cantón Quito asumió el discurso de vecindad entre los moradores como referente de identidad de los barrios populares, el que desconocía o excluía las antagónicas relaciones culturales del ya complejo mundo popular quiteño, sean aquellas existentes entre las comunas indígenas sometidas a la ciudad o las nuevas que surgían en otros ámbitos urbanos más allá de la órbita de la vecindad. La federación, al tiempo que buscaba el apoyo filantrópico en las obras de los barrios populares, también se dedicaba a las elecciones municipales, pues estaba adscrita a la Federación de Barrios, Ciudadelas y Parroquias Rurales de la provincia de Pichincha, dirigida por notables personajes de las aristocráticas familias quiteñas y consagrada al respaldo electoral del Partido Liberal, por aquellos años en tensión con el denominado Movimiento Nacional Velasquista (Últimas Noticias 1954). Con lo que en realidad ambas federaciones, la cantonal y la provincial, operaban como extensiones electorales de este partido.

En el curso de pocos años surgieron nuevos barrios en los predios periurbanos asentados hacia el sur y distantes del centro de la ciudad, en los que se extendieron las demandas de infraestructura y servicios básicos (Últimas Noticias 1953). Los comités barriales que se formaron en los nuevos asentamientos empezaron a juntarse, por su propia iniciativa, para coordinar la esforzada tramitación de los requerimientos barriales y ampliar la intermediación con los centros del poder urbano, 
para lo cual fundaron en 1953 la Asociación de Barrios de la Zona Sur, la que más tarde, en los años 70, amplió su membrecía a comités de damas de acción social, agrupaciones proconstrucciones, cooperativas de vivienda, entidades deportivas y comités de padres de familia, en defensa de los intereses de la comunidad (A. M. n. ${ }^{\circ} 1127$ 1976).

El surgimiento de la asociación, junto con la progresiva organización de otros comités promejoras en los nuevos barrios que se formaban en las extensas planicies y laderas al sur de la ciudad, cuyas dirigencias también tramitaban por su cuenta los requerimientos de infraestructura urbana, puso en evidencia el distanciamiento geográfico y cultural de los nuevos barrios periféricos sureños con la Federación de Barrios y Ciudadelas de Quito. Lejanía que, al tiempo que acentuaba la imagen de los barrios del sur como precarios y carentes de servicios (Unda 2008), tensaba su adscripción urbana al relegarles de la retórica de vecindad moldeada en los viejos barrios del centro de la ciudad.

Con el paso del tiempo la Federación de Barrios de Quito evidenció su limitado alcance organizativo frente al dinámico aparecimiento de los nuevos barrios periféricos y populares, lo que en la siguiente década provocaría su crisis y pérdida de representatividad, no obstante su pervivencia hasta la actualidad como una organización de segundo grado y sin peso político en la ciudad.

A inicios del año de 1963 se creó una nueva, quizá paralela, agrupación de comités barriales con el Consorcio de Barrios de la Zona Sur que reunía dieciocho comités barriales, a los que progresivamente se fueron integrando otros más, de los asentamientos periféricos del sur y del costado centro-occidental: Ferroviaria Alta, Ciudadela Militar Atahualpa, San Bartolo, Chaguarquingo, Pérez Pallares, Marcopamba, El Panecillo, Villa Flora; del costado occidental: San Juan, Toctiuco; las lotizaciones de la exhacienda Chiriyacu Suroriental, Chiriyacu Central, Chiriyacu Nororiental; los barrios de reciente constitución: Los Andes, Independencia Norte, Amazonas de San Juan, 5 de Marzo, 24 de Mayo y Miraflores de Toctiuco, y los barrios formados por conurbanización como Guajaló y Chillogallo (30). 
En la década de los 60 la ciudad experimentaba un ambiente proclive a la organización popular, promovido por los programas de la ALPRO, la que haciendo suyo el concepto de "marginalidad" veía a la población empobrecida como confinada a culturas tradicionales que les inhabilitaban para el adelanto social, ante lo cual impulsaba el "cooperativismo y el desarrollo comunitario" con el propósito de convertir a las poblaciones marginales en actores del progreso y la modernización.

Influenciados por el enfoque que las Asociaciones Mutualistas de Ahorro y Crédito para la Vivienda (ALPRO 1962) y la presencia en la ciudad de algunos organismos internacionales como la Agencia Internacional de Desarrollo (AID) que, junto con inversiones de organismos internacionales como el BID, CARE, PUNTO IV, direccionó en 1961 la creación del BEV, y promovió los primeros planes de "vivienda social". El Cuerpo de Paz introdujo en determinados circuitos barriales de Chilibulo, San Juan y Chiriyacu los iniciales emprendimientos asociativos comunitarios.

También tenían presencia las instituciones nacionales influenciadas por la ALPRO, como Acción Cívica de las Fuerzas Armadas que implementaba programas de ayuda comunitaria, una suerte de "responsabilidad social barrial", dirigida a los barrios en los entornos de los recintos militares, y que ocasionalmente se extendía a otros barrios contiguos con contribuciones materiales especialmente para la edificación de las casas barriales (ALPRO 1963). Los nombres de origen americano que se dieron a varias casas comunales de los barrios pericentrales obedecían a su influencia.

Los agentes externos inducían modelos asociativos para la consecución de servicios; ese fue el caso de las "cooperativas de vivienda", clasificadas como cooperativas de servicios, que tuvieron una notable evolución en los años 60 con la creación de la Dirección Nacional de Cooperativas del Ministerio de Previsión Social, que promovió el "desarrollo del cooperativismo" con el auspicio técnico y financiero de la AID, por medio de las agencias privadas norteamericanas Credit Union National Association y Cooperative League of the USA (Hurtado y Herudek 1974, 32).

La Iglesia católica empezó a tener otro tipo de presencia social en la ciudad. Más allá de la gestión de las antiguas parroquias eclesiales y 
de la pastoral social de las diversas órdenes religiosas en los barrios de la ciudad, mediante instituciones de la Conferencia Episcopal Ecuatoriana como el Instituto de la Vivienda Popular Cáritas del Ecuador (INVICA), que buscaba "contribuir a la solución de la vivienda en los grupos sociales de escasos recursos económicos” (A. M. n.o 4527 1965); de la fundación Cáritas del Ecuador dedicada a la "promoción humana y el desarrollo integral de los hombres” (A. M. n. ${ }^{\circ} 11759$ 1968), y de fundaciones ligadas a la Curia Metropolitana de Quito como la Asociación Tierra Nueva para la promoción humana cristiana en sectores marginales (A. M. n. ${ }^{\circ} 0550$ 1977), que estimuló el asociacionismo entre los moradores de los barrios pericentrales.

Las instituciones eclesiales comulgaban con el enfoque "interamericano de promoción del sistema de entidades privadas de ahorro y préstamo para la vivienda", y favorecieron el surgimiento de una nueva forma de organización barrial en las cooperativas de vivienda, algunas de las cuales, aunque tenían como propósito el ahorro, en los hechos buscaban conseguir tierra para nuevos asentamientos barriales.

Las nacientes cooperativas de vivienda en los asentamientos periféricos surgieron igualmente aisladas y sin capacidad de movilización. Empezaron como organizaciones que congregaban socios para futuras lotizaciones y urbanizaciones, con lo que en realidad funcionaban más como un dispositivo para administrar el control de la población y menos como una nueva forma de organización barrial autónoma (Unda 2008). Las cooperativas y precooperativas de vivienda se difundían en los nuevos barrios periféricos que brotaban en los terrenos ocupados con el ensanchamiento de la ciudad, y se estima que para el año 1967 se habían creado más de 140 cooperativas de vivienda en la provincia de Pichincha (Hurtado y Herudek 1974, 38), la mayoría de las cuales estaba en la ciudad de Quito.

Todas las nuevas organizaciones que se formaban: juntas, comités, cooperativas, precooperativas, asociaciones y federaciones, aspiraban a la intermediación entre los barrios periféricos y las instituciones públicas y privadas para satisfacer, en alguna medida, el sinnúmero de carencias básicas en los barrios periféricos. Como ha sido ampliamen- 
te reconocido, las demandas urbanas que se configuraron en los años 60 rebasaban por completo el cometido de las organizaciones barriales, abarcaban un amplio espectro de carencias materiales derivadas de la segregación urbana que anhelaban compensarse por medio de la gestión directa de la organización barrial.

Sin embargo, al igual de lo que sucedió con otros sectores populares, la capacidad colectiva de acceso a recursos, servicios e ingresos de autogestión barrial estaba en relación con el esfuerzo de los moradores por levantar niveles asociativos federativos, organizaciones de segundo grado (OSG), de modo que eslabonen redes, vínculos y alianzas en torno a los bienes comunes, cuestión que en dichos años todavía era incierta, y como he anotado, en el marco de la estructura modernizadora de la ciudad, enfrentaba una cultura refractaria.

Las demandas y expectativas de los moradores eran recogidas en lo que actualmente puede denominarse como la "agenda de hábitat popular", la que desde esos años hasta el presente se mantiene vigente aunque con ciertas modificaciones. Reseñada en algunos de los escasos diagnósticos barriales y en la mayoría de discursos de sus dirigentes, se convirtió en la plataforma de reivindicaciones comunes de los barrios periféricos capitalinos. La agenda de hábitat popular, llanamente, era el conjunto de carencias materiales de los nuevos asentamientos quiteños, entre las que obtener del título de propiedad del suelo era un elemento fundamental (Godard 1988, 191).

La agenda incluía desde obras de infraestructura básica (agua potable, alcantarillado sanitario, canalización, calles, aceras, escalinatas y bordillos); dotación de equipamiento urbano (alumbrado público, canchas, lavanderías, paradas, casas barriales y retenes policiales); acceso a servicios (agua potable, escuelas, centros médicos, guarderías, transporte y seguridad); hasta la gestión en el municipio para el ascenso de estatus o el cambio de denominación de algunos barrios, y la prestación de pequeños servicios por parte de los comités barriales (García 1985, Unda 2008, Borja 2011).

Pese a las penurias generalizadas en los barrios periféricos o no consolidados, los dirigentes de los comités barriales, contrariamente, 
continuaban priorizando la preparación de las fiestas de fundación de los barrios, las reediciones locales de las festividades religiosas de los lugares de origen de las numerosas colonias de vecinos recién emigrados, los eventos recreativos y deportivos barriales, y se adherían a las celebraciones cívicas y onomásticas de la ciudad. Se distanciaban, en la práctica, de la agenda de hábitat popular, convertida, por defecto, en una suerte de ilusión retórica de las dirigencias que reducía la diligencia barrial a la tramitación epistolar.

En esos años la gestión de las obras barriales no implicaba ningún tipo de movilización de los moradores, eso no cabía en las costumbres cívicas heredadas en la franciscana ciudad, pese al clientelismo de las autoridades locales. La tramitación se ceñía al acucioso envío de cartas y oficios con peticiones al municipio, prefectura, ministerios, embajadas, representaciones de organismos internacionales y eclesiales, redactadas en un estilo abundante en cortesías, formalidades y galantes declamaciones, que a manera de retórica parlamentaria popular, y contrariamente al propósito de expresar los intereses barriales, servía como dispositivo discursivo que replicaba en el ámbito barrial la imagen de pacífica ciudad (Últimas Noticias 1952). En algunas ocasiones y frente a reclamos de los requerimientos más básicos, los dirigentes delegaban "comisiones generales" que, previo al envío de una solicitud, eran eventualmente recibidas en las sesiones ordinarias del cabildo quiteño (Achig 1981).

El discurso vecinal de los dirigentes no comunicaba las necesidades de los moradores hacia fuera de los barrios; al contrario, recreaba al interior de los barrios los valores de la jerarquía aristocrática de la ciudad. La mayoría de los dirigentes asumían una actitud distinta afuera de los barrios de la que tenían dentro de estos: hacia afuera adoptaban un sumiso comportamiento de formalidad y amaneramiento parlamentario, en una ambigua postura que se expresaba incluso en la corporeidad de sus procederes; mientras hacia adentro mantenían las distancias jerárquicas con sus vecinos.

La intermediación de los dirigentes barriales, independientemente del tipo de trámite que realizaban, se convertía más en una búsqueda personal de afirmación social y de reconocimiento político por parte de los 
"agentes externos" y menos en una gestión compartida de las obras requeridas por los moradores (Últimas Noticias 1953), con lo que no siempre se acoplaban suficientemente sus iniciativas con los requerimientos barriales. Era común que a la actitud individual de las dirigencias barriales le acompañe la constante queja de falta de participación y colaboración de la gente en los comités y en la tramitación de las peticiones barriales.

Es que las dirigencias barriales no eran ajenas al orden jerárquico de las élites quiteñas que gobernaban patrimonialmente la "pacífica ciudad", el discurso vecinal les permitía ser parte de una cultura urbana de docilidad y acatamiento refrendado por su relación con el sistema político que mantenía el control de los gobiernos municipal y provincial. En consonancia, la mayoría de comités barriales y cooperativas de vivienda también operaban como extensiones de las maquinarias electorales, con las que los líderes y caciques de los partidos populistas se promocionaban en un interesado intercambio de lealtades por favores. Condicionaban los ofrecimientos de acceso a los recursos públicos y eslabonaban verticales encadenamientos clientelares entre las autoridades locales, las dirigencias barriales y los partidos políticos que se activaban sobre todo en los períodos electorales, desdibujándose los contornos entre los comités barriales y los comités electorales.

En el medio barrial capitalino se volvió tan usual el clientelismo que el control partidario de las ligas deportivas barriales y sus asociaciones aseguraba el arribo de algunos líderes a las concejalías y empleos municipales. Asimismo, en el sur de Quito era común que los dirigentes de los comités barriales se preciaran de haber trabajado por el candidato ganador, y de "tener buenas conexiones con el gobierno de turno", ya que las organizaciones barriales habituadas al caciquismo se convertían en funcionales “aparatos barriales" de los partidos políticos capitalinos (Quintero 1985, 201-2).

Por su lado, el municipio, carente de enfoques y políticas sociales, operaba con absoluta discrecionalidad en el campo social, promovía exiguos auspicios para las festividades barriales y esporádicos contactos con los comités barriales y cooperativas de vivienda en la tramitación de sus requerimientos, con quienes, en el marco de las incipientes orien- 
taciones de "desarrollo comunitario", se limitaba a alentar la adopción de la "minga barrial" como el mecanismo solidario con el que los pobladores autosatisfacían parcialmente sus carencias de infraestructura y equipamiento urbano.

La minga, no obstante de ser un atávico dispositivo cultural enraizado en las tradiciones de reciprocidad de la mayoría de habitantes de los barrios periféricos, era promocionada por las autoridades municipales como una novedad colaborativa de reciente valorización en la ciudad, debido, paradójicamente, a la influencia de los agentes externos y no a la orientación municipal para revitalizar una institución cultural de profunda raigambre popular.

La relación del municipio quiteño con los habitantes y barrios periféricos era principalmente clientelar, ejercida con estilos verticales y directos. Dada la estirpe nobiliaria de las autoridades locales, no acostumbraban tomar en cuenta, que no sea de modo ocasional, a las organizaciones barriales, pese a que muchos de los comités promejoras en los barrios periféricos fueron creados como parte de la organización local del Partido Liberal.

A manera de corolario y para mantener la imagen de respaldo popular de las autoridades municipales, algún prominente comité barrial o una asociación de barrios era ocasionalmente movilizado en las convocatorias al Cabildo Abierto (Borja 2011), que en la usanza municipal capitalina era la mayor instancia de consulta y respaldo privado de las decisiones públicas, integrada únicamente por los notables de la ciudad (expresidentes, exalcaldes, representantes de las cámaras, gremios empresariales y grupos económicos), quienes en situaciones de crisis deliberaban sobre los asuntos cruciales de la vida política y económica de la capital y el país. Su sola instalación refrendaba el aristocrático simbolismo del orden piramidal de la sociedad quiteña: unas pocas personalidades de encumbradas familias residentes en los barrios exclusivos del centro norte ratificaban las decisiones municipales en nombre de todos los habitantes de la ciudad.

Más tarde, en los primeros años 70, el auge económico de las exportaciones petroleras estimuló la expansión metropolitana de la capital 
con la renovación urbana del viejo centro, la redefinición de una nueva centralidad extendida en el centro norte, la modificación de la relación centro-periferia con el crecimiento urbano hacia los extremos norte y sur, y sobre los valles contiguos. Quito pasó rápidamente de la antigua forma pericéntrica a una forma distinta longitudinal y policéntrica; como consecuencia del disperso crecimiento económico, demográfico y territorial sobre las parroquias rurales, funcionalizó los centros poblados impactados por el incremento de la población y los requerimientos de infraestructura, servicios y equipamiento (Carrión 1987, 85).

Nuevas cooperativas de vivienda y comités barriales emergieron en los barrios periféricos y lotizaciones que aparecían por todos los costados de la capital, las que aunque importantes en número no tenían mayor fuerza de movilización barrial. Asimismo, con la consolidación de las zonas industriales en los extremos norte y sur de la ciudad conforme el esquema de ordenamiento territorial vigente, la segregación urbana se irradió al intensificarse la preexistente segregación norte sur, mantenerse la segregación centro-periferia y nuevas segregaciones periféricas en los recientes barrios populares de los costados occidental y oriental y de los extremos de la ciudad.

A esta tendencia contribuyeron los programas de vivienda de interés social implementados por el Gobierno central. Si bien los planes de vivienda localizados al norte (San Carlos, San Pedro Claver y Carcelén) y al sur (Solanda, La Mena, Marianitas, Las Cuadras) estaban dirigidos para los estratos sociales medios y bajos, en los hechos estimularon el surgimiento, en sus contornos, de asentamientos precarios en los que también se reproducía la segregación urbana como los barrios periféricos de Bellavista, El Bosque, El Triunfo, entre otros, al noroccidente, y los barrios periféricos de Matovelle, La Argelia, Ecasa, Concepción, Hierba Buena, Aída León al suroccidente. Con el propósito de atender los requerimientos de los nuevos barrios se formó el Consorcio de Barrios del Norte de Quito en 1972, que declaró como su área de acción los barrios populares asentados "desde la Av. Orellana hasta Cotocollao" y se proponía “obtener de los Poderes Públicos y Municipales” la preferente atención a las demandas barriales (A. M. n. 4091 1972). 
A comienzos de la década de los años 70, con el crecimiento de la ciudad, habían aumentado las organizaciones barriales, estimadas en alrededor de 38 comités promejoras de los barrios tradicionales centrales y pericentrales, 32 comités y cooperativas en los barrios ilegales del sur (IMQ 1980, 197), tres asociaciones de barrios de segundo grado y una federación de ligas deportivas barriales. No obstante su crecimiento cuantitativo, las dirigencias barriales continuaban dedicadas más a las actividades celebrativas y recreativas de los barrios y la ciudad y menos, mucho menos, a la gestión de la agenda de hábitat popular (Borja 2011,21).

En el año 1971 la pasiva y voluntarista rutina de los comités barriales capitalinos se alteró con la irrupción de un inédito protagonista popular que empezó a modificar el discurso y las prácticas de organización y movilización barrial. Era el Comité Provivienda Popular denominado Comité del Pueblo que, vinculado al Partido Comunista Marxista Leninista del Ecuador (PCMLE), agrupaba a vendedoras ambulantes, emigrantes campesinos recién llegados y arrendatarios empobrecidos de los barrios ilegales, a quienes la izquierda tradicional concentrada en apoyo al movimiento sindical con el recién creado Frente Unitario de Trabajadores (FUT) y, desde una visión ortodoxa clasista, no los consideraba como un actor relevante en la lucha social, sino como un "lumpen proletariado", esto es un estrato residual de la lucha de clases y sin peso en el ámbito popular (Bravo 1980).

El Comité del Pueblo apoyado en un comienzo por la militancia partidaria, estudiantes y docentes universitarios, se abrió paso en el espacio público capitalino de modo distinto al acostumbrado por los comités barriales vecinales: dividió a la ciudad en diez sectores y no en barrios, convocó indistintamente a pobladoras empobrecidas, mayoritariamente mujeres, y trazó su propio perímetro simbólico de expresión política en los entornos de la Universidad Central del Ecuador (UCE). Proclamando consignas radicales que polarizaban a la sociedad quiteña entre "ricos y pobres, malos y buenos", el Comité del Pueblo realizó sonoras marchas hacia el municipio demandando un precio bajo y fijo de la tierra, y protagonizó las primeras tomas de tierras como presión para su posterior adquisición en predios de la Fundación Mariana de Jesús o 
de la familia Mena del Hierro, las que fallaron debido al blindaje legal de la administración jesuita o porque fueron interferidas por los programas de crédito popular del entonces BEV (Borja 2011, 16-8).

Tras el radicalismo del Comité del Pueblo, en buena medida motivado por la influencia de la militancia de izquierda, se esbozaba el respeto a la propiedad privada y su disposición a la compra de tierras, la que se concretó en el año de 1974 con la adquisición de la hacienda La Eloísa al nororiente de Quito, donde se resolvió la necesidad de tierra y vivienda de sus integrantes, y la organización entró en una "fase de estabilidad" (2011), dedicada a implementar la infraestructura y el equipamiento urbano. Así, lo que al inicio fue una propuesta de cuestionamiento al orden urbano, que se pretendía más allá de lo barrial, terminó como un dispositivo promotor de barrios por medio de la compra de tierras, pues de la experiencia del Comité del Pueblo se desprendieron varios emprendimientos provivienda popular que adquirieron otros predios urbanos y periurbanos en los que se formaron nuevos barrios periféricos.

Asimismo, a mediados de la década de los 70, la recién creada Unión Ejecutiva Barrial del Sur (UNEBA), circunscrita a unos cuantos barrios que congregaban población predominantemente obrera y considerados en el imaginario de izquierda de sus dirigentes como "barrios proletarios", tenía su sede en el parque central del barrio La Ferroviaria en las instalaciones cedidas por el municipio, en las que, a más de la tramitación de algunas obras de equipamiento urbano, prestaba pequeños servicios de biblioteca popular, salón de actos y canalizaba una serie de cursillos de capacitación, temáticamente dispersos, en principio orientados a los dirigentes barriales y luego a la población en general, los que eran impartidos por varias entidades estatales.

Apoyada por jóvenes militantes del Partido Socialista Revolucionario Ecuatoriano (PSRE), la UNEBA se constituyó en el epicentro barrial de una activación política que incluía festivales de música y teatro de "denuncia social", animando mítines y marchas callejeras que buscaban establecer un puente político entre el movimiento barrial y el movimiento obrero organizado en el recién creado FUT. Las jornadas barriales en La Ferroviaria estaban cargadas del simbolismo cultural de 
la izquierda, levantaban acciones de solidaridad con los conflictos laborales que vivían los sindicatos en las fábricas del entorno, al tiempo que promovían el respaldo barrial al período de huelgas nacionales del FUT que empezó por esos años. Episódicamente, en el espacio público barrial se superponían el costumbrismo vecinal y el activismo de las consignas políticas de la izquierda.

A fines de la década, la ciudad vivió un episodio de alta conflictividad política, provocada por un decreto del triunvirato militar de elevar los pasajes del transporte público en Quito y Guayaquil que desató, en rechazo, fuertes movilizaciones populares e intensas jornadas de luchas barriales. Fue la denominada guerra de los cuatro reales ${ }^{6}$ acaecida en abril de 1978, cuando durante veintitrés días los estudiantes secundarios, universitarios y barrios populares quiteños, apoyados por el Movimiento de Izquierda Revolucionario (MIR) y el Partido Socialista Popular (PSP) se levantaron masivamente con los denominados Comités de Defensa Popular, en oposición a los cuarenta centavos de alza en los pasajes (Herrera 2012).

El pasaje del transporte urbano se fijó en 1946 por el primer alcalde de Quito, Jacinto Jijón y Caamaño, quien con una visión de modernización conservadora suprimió el funcionamiento del sistema de tranvías eléctricos existentes desde 1913, reemplazándolos por el servicio de buses y colectivos, y fijó el precio del transporte en un sucre, que se mantuvo por cerca de 32 años. Fue una medida que estandarizó por arriba el precio del transporte urbano y por abajo la calidad del servicio, tendencia que se mantiene hasta la actualidad pese a las innovaciones municipales en la materia.

El transporte público en Quito, entrados los años 60, era de tres categorías diferenciadas por colores: los descoloridos y abultados buses populares llamados "paperos" costaban veinte centavos de sucre o dos

6 Reseñas y testimonios sobre este acontecimiento se pueden encontrar en estos textos: Alejandro Santillán, Raúl Borja, Simón Corral, comps. 1979. La guerra de los cuatro reales: Recopilación de testimonios del pueblo de Quito. Quito: El Conejo; y Francisco Herrera Araúz. 2012. Si callan a los míos... gritarán hasta las piedras. Quito: MDMQ. 
reales y transportaban a usuarios literalmente apiñados como costales de papas; los pequeños buses de color gris opaco denominados "micros" costaban cincuenta centavos o cinco reales, transportaban usuarios sentados y parados; y los celestes "colectivos" de un sucre solo llevaban pasajeros sentados. Las cooperativas de transporte combinaban indistintamente los tres tipos de buses, pero las líneas se diferenciaban: a los barrios residenciales iban colectivos y micros, mientras a los barrios populares solo los paperos. Poco tiempo después se unificó el pasaje del transporte urbano en un sucre.

Lo que empezó como un reclamo a una medida antipopular se transformó en un "combate popular contra la dictadura"; combinó confrontaciones con los transportistas, paros y marchas estudiantiles, invasiones policiales a centros educativos y hospitales, la clausura de dos radiodifusoras, una masiva movilización interbarrial denominada marcha de las cacerolas, que fue reprimida brutalmente, lo que recrudeció la protesta popular que se parapetó en numerosas barricadas e intermitentes fogatas diseminadas en los barrios populares de la ciudad. Las jornadas de lucha barrial dejaron de saldo más de 300 personas detenidas y tres muertes, hasta cuando el Ejército ocupó las calles y paulatinamente la ciudad recobró la calma (CEDEP 1982, 18-20).

Las condiciones socioorganizativas del movimiento barrial quiteño habían cambiado. Los comités promejoras pasaron de la retórica tramitación de las pocas demandas barriales, que se hacían en el marco de las costumbres patrimoniales legadas, a la movilización pública en las calles y plazas como presión para la consecución de la agenda barrial popular. Ocurrió que el movimiento barrial capitalino había entrado en una fase de transición en los años 70, la que empezó con la masiva irrupción del Comité del Pueblo, continuó con las jornadas de La Ferroviaria y desembocó en la lucha interclasista en la guerra de los cuatro reales; mostraba la obsolescencia de los pasivos comités barriales, el desgaste del estilo epistolar de sus dirigencias y era el preámbulo de una inédita oleada de organización y movilización popular urbana que ocurriría en las siguientes décadas.

La fase de transición del movimiento barrial capitalino en los años 70 coincidió con el extendido período del alcalde socialcristiano 
Sixto Durán Ballén, en el que la subordinada relación de los comités barriales con el municipio empezó a modificarse con las primeras movilizaciones barriales que presionaban por el derecho a la vivienda y la consecución de las obras públicas. La activa presencia de numerosos moradores en mítines y marchas por las calles y plazas, unos exigiendo tierra y vivienda urbana, otros en rechazo a las medidas gubernamentales, rebasaban los personalismos de las dirigencias barriales. Las organizaciones barriales paulatinamente innovaban sus prácticas y exhibían nuevas formas de lucha social, influenciadas por el contacto con los movimientos estudiantiles y de izquierda que también se habían dinamizado en esos años.

El movimiento barrial capitalino, que había empezado su trayectoria en los años 40 con los comités de adelanto o promejoras de los barrios tradicionales, despuntaba, en los años 70, como un actor de la política urbana que empezaba a mostrarse como portador de intereses propios y activado políticamente. Su conversión del estilo epistolar a la movilización barrial se dio junto con el incremento de las organizaciones barriales y el surgimiento de nuevos barrios periféricos, cuando empezó la imbricación de las presiones por la agenda barrial popular con la lucha más amplia del movimiento popular urbano.

Los habitantes de los barrios periféricos y populares habían cambiado en el transcurso de dichos años. El estudio de Santiago Carcelén (1977), que analizó una muestra de los barrios periféricos, encontró que según la rama de actividad más del $61 \%$ de sus habitantes se concentraban en actividades del sector terciario, predominando el comercio (13,5\%), servicios $(24,7 \%)$ y artesanos (12,5\%), apenas el 6,5 \% de la población estaba ocupada en actividades en el sector industrial; lo que se ratificaba al analizarlos por categoría ocupacional y registrar que más del $76 \%$ de las ocupaciones eran por cuenta propia, predominando los jornaleros (30,2\%) y empleados (25,3 \%), mientras el 19,9\% eran obreros asalariados (1977). La nueva población de los barrios populares estaba concentrada en el sector terciario, en el comercio y los servicios de la ciudad.

Asimismo, el peso específico de la población de los barrios periféricos en la ciudad se había incrementado. A finales de la década de los 
70 en los barrios periféricos residía cerca de un cuarto de la población de Quito: 45 \% estaba ubicada en la periferia de la zona norte, $22 \%$ en el centro y $32 \%$ en la periferia sur, conformando un arco popular extendido entre los extremos de la ciudad y hacia los pequeños poblados de las parroquias rurales del entorno, que había sido persistentemente ignorado por las administraciones municipales (CIUDAD 1982), y que recién en 1978 las autoridades locales reconocieron, presionadas por los afanes de control y clientelismo electoral derivados de la transición a la democracia que vivía la ciudad y el país.

Henri Godard mostró que en los años 70 también habían cambiado las relaciones entre los arrendatarios empobrecidos de los barrios del centro y los propietarios del norte: antes, los niveles organizativos eran débiles y sus demandas estaba dispersas, con el crecimiento de los nuevos barrios se rompieron esos vínculos entre arrendatarios y propietarios, encaminando el rápido crecimiento de las organizaciones barriales que "presionaron a las instituciones" y vigorizaron el "sentido de solidaridad" (1988a, 134).

En las nuevas condiciones demográficas y ocupacionales de la población de los barrios periféricos, el tradicional movimiento barrial constituido por propietarios individuales de viviendas representados en la Federación de Barrios de Quito se mostraba obsoleto, y fue desplazado del espacio público capitalino por las nacientes organizaciones provivienda y de arrendatarios y por las primeras asociaciones de los barrios periféricos del sur y norte, que en adelante constituirán el eje del movimiento barrial capitalino.

La personalista práctica celebrativa de la dirigencia barrial y el discurso vecinal estaban siendo removidos por un larvario "sentido de los bienes comunes" que empezaban a adoptar las organizaciones barriales, estimuladas por las iniciales movilizaciones de sus moradores que intentaban hacer suya la agenda barrial popular, por el enriquecedor contacto con los movimientos estudiantil y de izquierda, y por la adopción de renovadoras formas de lucha poblacional que empezaban a copar los espacios públicos capitalinos. 


\section{El auge: Expansión de la lucha poblacional}

A comienzos de los años 80 , la transición hacia la democracia y el inicio de una etapa de estabilidad política encontró al movimiento barrial quiteño en un intenso proceso de legalización y ampliación de sus organizaciones, tanto de aquellas establecidas con la formación de los primeros barrios periféricos desde mediados y a finales de la década precedente, cuanto en los nuevos barrios periféricos formados en los albores de los años 80 , que iba a la par de una creciente efervescencia social. Un inusitado impulso hacia el reconocimiento legal de las organizaciones populares, en un contexto de entusiasmo democrático, marcó el inicio de un segundo período del movimiento barrial en la capital, que a diferencia del anterior se caracterizó por el dinamismo organizativo, la intensa movilización de la lucha poblacional y la creciente capacidad de interlocución de los barrios populares y periféricos con el gobierno municipal.

La ciudad vivía un ambiente de agitación social estimulado por las sucesivas huelgas nacionales del FUT que tenían como epicentro la capital del país, por las constantes movilizaciones barriales en demanda de tierra, vivienda e infraestructura, por el fomento y legalización de las numerosas organizaciones sociales que impulsaba el recién creado Ministerio de Bienestar Social y Promoción Popular, escindido del Ministerio de Trabajo (Unda y Barrera 1998, 19). Estimulado también por los trece movimientos, partidos y coaliciones electorales alineados en el espectro de posiciones políticas de derecha, centro e izquierda que en la ciudad disputaban la Alcaldía de Quito y la Prefectura de Pichincha, e ingresaban a los barrios populares y periféricos para remozar sus vínculos clientelares con ofrecimientos sobre la anhelada y postergada agenda barrial popular.

El segundo período del movimiento barrial se desplegó durante las primeras seis alcaldías de la etapa democrática. Empezó con la alcaldía de Álvaro Pérez Intriago, quien heredó las maquinarias electorales barriales superpuestas a los comités electorales del Partido Liberal, y continuó con la política de indiferencia clientelar hacia los barrios periféricos. Luego con la alcaldía del radiodifusor Gustavo Herdoíza, 
conocido como el Maestro Juanito, quien, auspiciado por el Partido Demócrata, extendió y profundizó las redes clientelares por todos los barrios periféricos, llegando incluso a cooptar a los dirigentes de las federaciones barriales, algunos de los cuales pasaron a ser funcionarios municipales durante su alcaldía.

Posteriormente, en la alcaldía de Rodrigo Paz, que inició la temporada de alcaldías de la DP, se funcionalizaron las redes clientelares barriales, alineándolas con su partido político. El alcalde trasplantó un equipo político-comunicacional al sur de la ciudad, que se dedicó a reorganizar las redes clientelares, esparciéndolas por todos los barrios periféricos, tendencia que continuó en las dos subsiguientes alcaldías de Jamil Mahuad, que cerró la temporada de alcaldías de la DP, a finales de la década de los 90 .

La expansión metropolitana había elevado considerablemente el número de barrios populares: a comienzos de los 80 el municipio llegó a reconocer legalmente 87 barrios periféricos que compartían desiguales carencias de infraestructura, equipamiento y servicios urbanos (Carrión 1987), en los que se habían formado cooperativas y comités barriales en procura de gestionar sus requerimientos básicos. No obstante, según varios estudios (Ponce 1998, Martínez 1983), en esos años había un subregistro de más de la mitad de los barrios periféricos y populares capitalinos, lo que indicaba la persistencia de la vieja práctica municipal de ignorar la existencia de los barrios periféricos y sus organizaciones, pese a los avances territoriales de los partidos políticos que buscaban ampliar sus comités electorales en los barrios populares.

Considerando el subregistro y basado en las entrevistas realizadas, estimo que al inicio de la década de los 80 se habían formado alrededor de 160 organizaciones barriales y provivienda en la ciudad, casi la mitad de ellas establecidas de facto, de hecho, sin reconocimiento jurídico, bajo la figura de precooperativas, cooperativas, comités promejoras y comités barriales que estaban dispersos por todos los costados de la capital.

El dinamismo de las organizaciones barriales era distinto al de los años anteriores no solo por su notable aumento numérico, sino porque los habitantes de los barrios periféricos y populares, que hasta el mo- 
mento habían sido caracterizados como vecinos, se descubrían como estructuralmente heterogéneos y culturalmente diversos. En los barrios periféricos se evidenciaba una creciente complejidad sociocultural de sus moradores (Alvarado 2014), compuestos por una mezcla de emigrantes rurales recién llegados, arrendatarios oriundos de los viejos barrios y tugurios de la ciudad, comuneros asentados ancestralmente o autoidentificados como tales, exhuasipungueros de las antiguas haciendas, entre otros grupos humanos con singulares matrices culturales y precarias inserciones económicas.

En los nuevos barrios periféricos, signados por la diversidad de sus habitantes, brotaban múltiples intereses colectivos junto con nacientes asociatividades que rebasaban a las tradicionales organizaciones vecinales. Al lado de los comités promejoras emergían nuevas presencias (2014), se conformaban agrupaciones de arrendatarios, mujeres, migrantes, jóvenes, indígenas y afrodescendientes en torno a inéditas demandas identitarias, económicas, educativas, de salud, religiosas y recreativas.

Las nuevas agrupaciones paulatinamente disputaban las instancias organizativas y los sitios públicos en los barrios. Algunas trataron de enmarcarse dentro de los comités promejoras, otras surgieron por fuera de estos, con lo que empezó el remozamiento y ampliación organizativa del campo de lo popular urbano. A mediados de los años 80 Jorge García mostró "la riqueza del mundo poblacional” quiteño, como consecuencia del incremento de las acciones colectivas frente al deterioro de la subsistencia de la población pobre en la ciudad y registró una amplia gama de organizaciones barriales relacionadas con las demandas del nivel de vida de la población, entre las que estaban cabildos, comunas, "comités promejoras, clubes, asociaciones culturales y deportivas, asociaciones, centros de mujeres, juntas vecinales, ligas deportivas, agrupaciones juveniles, cooperativas, sociedades, colonias, comunidades cristianas, comités centrales, federaciones, uniones, coordinadoras" (1985, 24-5).

El crecimiento organizativo de lo que dio en llamarse el "movimiento poblacional" estuvo relacionado, de modo predominante, con la formación de los numerosos asentamientos humanos de naturale- 
za irregular y urbanísticamente segregados que surgieron por todos los flancos de la urbe, vinculados, en su mayoría, con el tráfico de tierras que fue la vía mediante la cual significativos contingentes de población empobrecida accedían al suelo y a la vivienda urbana.

Recuérdese que la mayor parte del territorio sobre el que se expandió la ciudad, tanto en el que se formaron los barrios de clase media y alta como el de los asentamientos populares y periféricos, eran haciendas y predios rurales de propiedad de contadas familias rentistas, de algunas órdenes religiosas y de entidades públicas como la Asistencia Social y el Ministerio de Salud que, siguiendo el patrón de segregación urbana y las políticas municipales, se convirtieron en áreas urbanas mediante dos modalidades entrelazadas: el mercado inmobiliario y el tráfico de tierras. Empezaba la sui géneris expansión urbana de Quito con la "evolución no productiva de las haciendas y minifundios", mediante la urbanización directa de haciendas promovida por "latifundistas metamorfoseados en rentistas urbanos” (Estévez 1984, 272), y la urbanización derivada de la evolución de la hacienda en minifundio.

La estrategia de los propietarios rentistas de haciendas era reservar las mejores tierras de los valles y planicies para venderlas como fincas vacacionales y huertos familiares a los estratos de ingresos altos, las que posteriormente se convirtieron en áreas residenciales suntuarias, y se formaron las urbanizaciones y ciudadelas para la pequeña burguesía urbana; mientras las tierras en zonas altas eran entregadas a huasipungueros o campesinos que también vendieron sus lotes, donde con el paso del tiempo surgieron los barrios periféricos (277-8).

El mercado inmobiliario del cual forman parte las empresas urbanizadoras se enfocó principalmente en los crecientes sectores medios y altos, y transformó las tierras rurales en áreas residenciales según los distintos segmentos de ingresos, dotadas de servicios y equipamiento de calidad, y localizadas en los mejores lugares pericentrales de la ciudad. Con el tiempo y la modernización urbana devinieron en zonas residenciales y comerciales exclusivas, en holgados barrios de clase media y en nuevas centralidades urbanas. 
El tráfico o venta ilegal de tierras para los sectores empobrecidos, inmigrantes del campo y arrendatarios, en cambio, funcionaba como dispositivo de intermediación, especulación y reventa de tierras rurales para planes de vivienda o directamente a cooperativas y precooperativas asentadas en extensos y distantes lugares carentes de infraestructura, servicios y equipamiento urbano, en los que se fundaron todos los barrios periféricos, denominados peyorativamente barrios ilegales, "lotizaciones fantasmas" o "asentamientos clandestinos", términos que denotaban su condición discriminada. Era el aparecimiento del "submercado" del suelo urbano como modalidad del desarrollo urbano (Martínez 1999, 340).

En unos casos el tráfico o venta ilegal de tierras consistía en un operativo de cuatro pasos: tomas de las haciendas inducidas por traficantes, negociantes y agitadores, presiones a los propietarios intimidados por las movilizaciones de los pobladores, negociaciones y venta de las tierras a intermediarios y posterior reventa a las organizaciones de pobladores conformadas con ese propósito. En otros casos los pobladores compraban los terrenos a intermediarios bajo figuras especulativas como lotizaciones en planos de terrenos descampados, lotes rurales en "huertos familiares" con la apariencia de fines productivos, reconversión de terrenos fragmentados de exhuasipungos y lotes en antiguos barrios absorbidos por el crecimiento de la ciudad (Borja 2011, 27-33).

Salvo el caso de las cooperativas Lucha de los Pobres, Atucucho, Jaime Roldós y Pisulí que surgieron con la toma de haciendas privadas y estatales, donde se asentaron los únicos cuatro barrios formados por invasiones, todos los demás barrios irregulares que surgieron por todos los costados de la capital fueron consecuencia del tráfico o venta ilegal de tierras. Para los pobladores la toma de las haciendas y predios era el inicio de un largo y tortuoso trayecto para adquirir la tierra, edificar la vivienda, acceder a la infraestructura, el equipamiento y los servicios urbanos, en el que en una densa maraña clientelar se mezclaban las dirigencias, autoridades municipales, caudillos, abogados, tinterillos, tramitadores y "palanqueadores", y se enredaban las iniciativas comunitarias en beneficio de los intereses individuales. 
En este ambiente la organización de los pobladores constituía el principal mecanismo que permitía dotarse, si bien de modo parcial y progresivo, de la infraestructura básica, los servicios y el equipamiento urbano con el que la gente transformaba los terrenos descampados en asentamientos humanos, en principio en condición irregular y, tras largos apremios, convertidos en barrios periféricos. Como lo señaló Raúl Borja (2011), la organización de los pobladores devino no solo en una condición para ocupar la tierra, sino en el mecanismo grupal que les posibilitaba, por medio de la presión y movilización, logros parciales en su legalización y posterior dotación de entornos urbanos mínimos, aunque en circunstancias inciertas.

La organización barrial era necesaria para proteger a los habitantes de los incumplimientos de los traficantes de tierras, para escudarse de los abusos de los intermediarios, para presionar y vigilar a los tramitadores; con la organización había más probabilidades de legalización de los lotes, así como lograr posteriormente el estatus regular de los barrios (Alvarado 2014). La formación de comités promejoras en los barrios periféricos continuaba siendo parte del intercambio de lealtades por servicios, propio del clientelismo político desplegado por las autoridades municipales y provinciales que inducían a su conformación, con lo que las nuevas maquinarias electorales capitalinas, inductoras en la formación de comités electorales superpuestos a los comités promejoras, también estaban detrás del incremento organizativo barrial.

Así, presiones políticas provenientes de la estructura de poder local, presiones sociales surgidas con la creación de intereses colectivos y organizaciones de los pobladores, y presiones pragmáticas de las dirigencias y liderazgos para la consecución de las obras físicas, confluyeron en el surgimiento de las organizaciones barriales. Explican el inusitado crecimiento que experimentó un pico elevado en corto tiempo y, luego, un paulatino incremento a lo largo de casi dos décadas, ya que solo en los primeros años 80 se legalizaron en la provincia de Pichincha el $51 \%$, y en la ciudad de Quito el 66,6 \% de las organizaciones populares urbanas (García 1985, 94-5). 
En medio de la expansión de las organizaciones barriales y poblacionales sobrevino un hecho distintivo del movimiento barrial quiteño con la fundación e irradiación, por todos los extremos de la ciudad, de las organizaciones barriales de nivel federativo, las OSG que, con distintas denominaciones (federaciones, coordinadoras, asociaciones, uniones y comités centrales), representaban zonalmente a los barrios, a los comités promejoras y a la diversidad de organizaciones emergentes.

En la ciudad los comités promejoras expresaban directamente, en el mismo plano de los pobladores, sus intereses inmediatos relacionados con el mejoramiento de las condiciones materiales de vivienda, y aunque entre ellos se formaron ciertos estratos de dirigentes diferenciados de las vecindades, en lo fundamental, eran la continuidad socioorganizativa de la cotidianidad barrial (CONBADE 2014, 7). Las OSG, en cambio, tendían a expresar y amplificar en los espacios públicos los intereses compartidos del conjunto de barrios periféricos y de la variedad de nuevas organizaciones juveniles, culturales, recreativas, de mujeres que emergían en los barrios de una determinada zona (Alvarado 2014). Las federaciones barriales condensaban las expectativas interbarriales de un sector periférico de la ciudad, y direccionaban — lideraban puedo decir-, las movilizaciones poblacionales desde determinado sector hacia los centros del poder capitalino.

En la primera mitad de los años 80, por todos los costados de la ciudad, se trazaron y construyeron extensas avenidas que fijaron el perímetro y la cota de servicios de la ciudad, afectando la accesibilidad a los barrios periféricos. Se tendieron redes de agua potable integradas al sistema de abastecimiento de la ciudad, las que absorbían o anulaban las pequeñas fuentes de agua de los barrios. Se priorizaba la construcción de los servicios de salud y educativos en las centralidades urbanas, dejando desguarnecidos de servicios a los barrios periféricos. Se implantaron zonas industriales en condiciones de riesgo en las inmediaciones de los barrios periféricos, entre otras medidas urbanísticas.

La mayoría de federaciones surgió por iniciativa y esfuerzo de los barrios periféricos que se juntaron en reacción a la implementación de las grandes intervenciones urbanísticas, ante las cuales resultaba inútil 
presionar individualmente desde el barrio, había que juntarse para enfrentar el embate de la política urbana metropolitana. Cada una de las federaciones emergió en un perímetro territorial simbólicamente establecido, en el que se agrupaba un determinado número de comités promejoras, cooperativas y precooperativas, en cuyo nombre empezaron esgrimiendo sus propias arengas de defensa interbarrial, elaborando planes de desarrollo barrial y propuestas zonales (CONBADE 2014, 8).

Desde el inicio sus discursos y prácticas interpelaron a la política urbana en nombre de los barrios periféricos y asumían, de facto, su custodia ante los sucesivos acometimientos que sufrían como consecuencia de los avances urbanísticos, al mismo tiempo que amplificaban la presión por las obras que mejorasen el hábitat popular, protagonizando intensas movilizaciones poblacionales en los bordes simbólicos de los espacios públicos. Se buscaba afirmar que los barrios periféricos también existían, que eran parte de la ciudad y que debían ser tratados como tales (8).

A las precursoras Federación de Barrios de Quito, Asociación de Barrios de la Zona Sur, Consorcio de Barrios de la Zona Sur y Consorcio de Barrios del Norte de Quito, se sumaron las nuevas federaciones fundadas entre los años 1979-1983: el Comité Central Marcopamba, la Federación de Barrios del Suroccidente, la Prefederación de Barrios del Suroccidente, la Federación de Barrios del Suroriente, la Coordinadora de Organizaciones del Sur, el Comité Parroquial Chillogallo, la Cooperativa Lucha de los Pobres, la Unión de Organizaciones Barriales de Quito (UOBQ), la Federación de Barrios del Noroccidente de Quito (FBNOQ), el Comité Pro Mejoras Chilibulo, la Federación de Barrios Marginales de Pichincha y la Coordinadora de Barrios del Sur (García 1985, 23 y 29).

La mayoría de los barrios periféricos capitalinos tenían membrecías en alguna de las dieciséis OSG, las que con distintas intensidades y variados matices levantaban reivindicaciones territoriales en concordancia con el estilo de gestión que adoptaban y, de cierta forma, acorde con la orientación de los aliados con que contaban. En unas federaciones predominaban las afiliaciones de base, pero no eran proclives a la movilización; otras, en cambio, junto con los comités promejoras concentraban el activismo y se inclinaban por los levantamientos barria- 
les; había las que combinaban la representación vecinal con un sentido técnico de la presión barrial, y aquellas que abiertamente promovían la lucha popular más amplia.

Entre ellas, por ejemplo, el Comité Central Marcopamba, que agrupaba quince barrios periféricos del suroccidente, estaba cercano a la acción pastoral de la Iglesia católica, promovía como reivindicación principal la construcción del Hospital del Sur y no era proclive a las movilizaciones barriales (Borja 2011). La FBNOQ que convocaba a cuarenta barrios periféricos, apoyada por varias oenegés, levantaba un discurso de gestión barrial y se movilizaba en nutridas marchas de pobladores en defensa de la tierra y por el reconocimiento de los barrios afectados por los impactos socioambientales de la construcción de la avenida Occidental, consideraba que "los derechos de los barrios se hacen respetar en los poderes urbanos con la movilización y la acción unificada” (FBNOQ 1991, 12).

La UOBQ surgió con la intención de agrupar a todas las organizaciones barriales de base y federativas de la ciudad, en una suerte de confederación barrial de tercer grado que se proponía enlazar a las variadas zonas o sectores de las federaciones barriales, y aunque tenía un discurso de reivindicación popular, se mostraba abiertamente clientelar, ya que se conformó con gastados personajes y caciques barriales inmersos en los tradicionales circuitos liberales enraizados en el poder local. Atrapada entre los compromisos personalistas de sus dirigentes, las presiones electorales de los nuevos partidos políticos y un accionar ambivalente, la UOBQ no pudo alcanzar el espacio público al que pretendía llegar, al poco tiempo se debilitó (Unda 1986, 240). La UOBQ fue una federación de viejo cuño y de inspiración vecinal, que nació desfasada del nuevo contexto de diversidad poblacional de la ciudad.

No cabe una generalización uniforme de las federaciones barriales, cada una experimentó una trayectoria singular en su conformación, aunque tenían como elemento en común una misma base social en las organizaciones de los barrios periféricos y la motivación de incluir dentro de los límites urbano a los barrios periféricos (CONBADE 2014, 7), las experiencias organizativas eran distintas, como disímiles sus entornos de aliados. 
Un rasgo común de todas las federaciones quiteñas, sin excepción, fue que en algún momento de su trayectoria se relacionaron clientelarmente con el municipio, pues las dirigencias de las federaciones, a su turno, fueron cooptadas por los alcaldes con ofrecimientos de recursos para sus zonas, empleos a sus dirigentes y en algunos casos incluso con puestos y promoción política. No obstante, en lo sustantivo, el aparecimiento de las federaciones evidenciaba el escalonamiento experimentado por las luchas poblacionales, así como los esfuerzos de agregación de los múltiples intereses que emergían en los barrios desde las organizaciones de vivienda, juveniles, recreativas, culturales, de mujeres y demás.

Las dirigencias de los comités barriales, fogueadas en las lides clientelares, no eran ajenas al avance organizativo, pues sin abandonar su práctica personalista cambiaban de actitud con las federaciones. Las dirigencias barriales, cuando estaban en los comités promejoras, reproducían los viejos discursos y comportamientos clientelares frente a las autoridades, notables y políticos; los mismos dirigentes cuando estaban en las federaciones, en cambio, asumían discursos y comportamientos cívicos que posicionaban y respaldaban a los barrios ante la política urbana. Los desplazamientos retóricos, en cierta forma, empalmaban las expectativas individuales de los habitantes con los intereses compartidos entre los barrios periféricos.

Ante la expansión organizativa, la narrativa vecinal era insuficiente para expresar el complejo ámbito reivindicativo que se gestaba en los barrios periféricos de la capital, ya no eran propietarios ni vecinos los que se movilizaban ni eran notables los que hablaban por los barrios, sino que, mediante las federaciones, eran los propios barrios periféricos los que irrumpían en los fraccionados espacios públicos capitalinos. La concordancia entre las antiguas presiones barriales por los requerimientos de equipamiento urbano, con las nuevas demandas de vivienda y los inéditos protagonismos populares urbanos, empezó a designarse en los años 80 como "movimiento poblacional".

Lo poblacional era tributario del enfoque teórico de las luchas sociales en la esfera de la reproducción social y material, en tanto generaban nuevas formas de organización barrial por el acceso a la vivienda 
y la consecuente convivencia comunitaria (Evers 1983). Se asumió como una mezcla discursiva influenciada y derivada del término "poblador", enraizado en los estudios urbanos chilenos (Pastrana 1971) y en las experiencias barriales en Lima (Gianella 1978), con el que se designaban a los habitantes de los barrios populares; adoptándose a manera de locus enunciativo del emergente sujeto popular urbano compuesto por diversos actores, intereses y organizaciones de los barrios periféricos y populares de la capital.

En lo poblacional se entrelazaban los anónimos relatos de las dirigencias, los imaginarios de los activistas de izquierda aliados a las organizaciones barriales y las historias de los barrios, aparejándose en una suerte de narrativa compartida que delineaba culturalmente a las trayectorias barriales periféricas, dejando atrás al discurso vecinal. Lo poblacional denotaba los nuevos protagonismos sociales motivados en la lucha por tierra y vivienda urbana, que estaban en interacción con otras nacientes organizaciones surgidas desde adentro de los barrios portando intereses diferenciados, aunque no excluidos, de los comités barriales.

El discurso poblacional, sin mayor debate académico ni político, fue introduciéndose de modo ecléctico en el lenguaje reivindicativo del movimiento barrial. Enfatizando en las mixturas de las luchas barriales, se distanciaba del enfoque ortodoxo que caracterizaba a los habitantes de los barrios periféricos como "subproletariado urbano", concepto que teniendo como referencia las "alianzas de clases" aludía a un segmento residual de las organizaciones sindicales y partidarias que, en esos años, se usaba de modo genérico para referirse a los habitantes de los barrios periféricos. Paradójicamente, el uso de la noción de subproletariado urbano velaba la comprensión de una parte de la sociedad urbana que se constituía en los barrios periféricos.

Lo poblacional, en cambio, designaba al amplio espectro de prácticas socioorganizativas que no pertenecían a las organizaciones obreras, campesinas y partidarias que estaban adscritas a múltiples espacios urbanos de distinta escala como barrios, parroquias urbanas, poblados, comunas, anejos y caseríos. Designaba también a las actividades culturales al interior de dichos espacios urbanos que acontecían en las can- 
chas deportivas, parques, plazas, casas comunales, casas barriales, postas de salud, conchas acústicas, entre otros, y que formaban parte de las condiciones de existencia social de los habitantes de los barrios periféricos y populares, así como de los circuitos de continuidad urbano-rural que pervivían en los nuevos asentamientos.

En lo poblacional se superponían, indistintamente, varias dimensiones sociales constitutivas del campo de lo popular urbano: los barrios como espacios colectivos de vivienda, las vecindades como afinidades domésticas de cercanía, los deportes como prácticas recreativas cohesionadoras, la educación en tanto demanda de servicios escolares, la salud como requerimientos de atención primaria, las identidades juveniles como ejercicio de nuevas sociabilizaciones, la valorización de los roles privados y públicos de las mujeres, las prácticas religiosas contestatarias $\mathrm{y}$, mediante las federaciones, lo interbarrial como expresión pública no estatal del ejercicio cívico de derechos urbanos.

En las dinámicas poblacionales se sumaban las presiones barriales por infraestructura y vivienda con las disputas simbólicas de los espacios públicos, los desplazamientos del denominado "voluntariado deportivo" con las iniciativas populares de autogestión económica y de servicios, la resistencia-adaptación de las comunas indígenas y las variadas identidades juveniles y de género emergentes. Asimismo, la perspectiva poblacional consentía los desplazamientos retóricos de las dirigencias barriales entre las necesidades prácticas y los intereses zonales, con lo que contribuía a enlazar discursivamente los requerimientos materiales de los moradores con las movilizaciones barriales, y al eslabonamiento de los comités promejoras con las federaciones barriales. De modo que durante los años 80 y 90, con el surgimiento de las federaciones y la adopción del enfoque de pobladores, las movilizaciones barriales capitalinas pasaron a designarse "luchas del movimiento poblacional" (Borja 2011).

Lo poblacional devino en un discurso y práctica compartida entre las organizaciones populares urbanas y los aliados políticos que operaban en el movimiento barrial. Entre ellas, las CEB y la militancia de izquierda que contribuyeron con el activismo a su consolidación, sea renovando sus imaginarios socioorganizativos, sea ampliando las bases 
sociales con el acercamiento de los comités y federaciones a las luchas de otros sectores populares.

Las CEB se instituyeron en el país a mediados de los años 70, con el propósito de fundar un movimiento cristiano de izquierda. Las primeras CEB en los barrios populares y periféricos del sur de la capital se formaron siguiendo dos orientaciones contrastadas: unas en el marco de la Doctrina Social de la Iglesia; otras, en los postulados de la Teología de la Liberación, impulsada por monseñor Leonidas Proaño.

Las CEB que se formaron en los entornos de la Doctrina Social de la Iglesia se expandieron desde los barrios Mena Uno y Quito Sur a los barrios periféricos en las dieciséis parroquias eclesiales recién creadas, en cada una de las cuales se formaron "casas parroquiales" e iglesias que estaban animadas por comprometidos equipos pastorales de monjas, sacerdotes, seglares y laicos, quienes con enfoque de aprendizaje práctico promovieron organizaciones alternativas con participación comunitaria, jóvenes y mujeres, reavivando los ánimos desgastados de los pobladores tras las tomas de haciendas y las presiones para la legalización de tierras y viviendas (102). En los barrios recién formados los equipos pastorales, sin rivalizar con los dirigentes y su agenda clientelar, impulsaban talleres artesanales, así como iniciativas de salud y educación, entre las que se conformaban CEB que, junto con la eucaristía, buscaban soluciones a los problemas cotidianos de los pobladores.

Las CEB formadas en los dominios de la Teología de la Liberación, a su vez, se irradiaron en los entornos de las casas parroquiales de La Tola, La Colmena, La Ferroviaria y desde allí hacia algunos barrios periféricos de la ciudad, guiadas por las orientaciones ideológicas de una Iglesia comprometida con las organizaciones populares y la dignificación del "pueblo indio" históricamente oprimido; estas CEB se acoplaron a las actividades de los comités barriales mostrándose como aliadas de sus luchas (104).

En los barrios populares de La Tola y La Colmena, las CEB, en paralelo al activismo político que promovían los vínculos entre las luchas poblacionales, obreras y campesinas, animaban el impulso de alternativas comunitarias a las necesidades de sus habitantes con la creación de 
centros de atención y cuidado infantil, tiendas comunitarias, subcentros de salud, incluso, en algún caso, la construcción del retén de policía para enfrentar la inseguridad barrial, para lo cual sus miembros gestionaban, no siempre con éxito, en las instituciones públicas y privadas los recursos necesarios (105). En La Ferroviaria las CEB apoyaban las lides sindicales de sus pobladores y dirigentes que, colmadas de paros, huelgas, despidos intempestivos, conflictos colectivos y cierres de las fábricas del entorno (106), continuaban con el acercamiento entre las luchas poblacionales y obreras, impulsado anteriormente desde la experiencia de la UNEBA.

Más allá de la trayectoria de las CEB y las cambiantes formas organizativas que adoptó el movimiento de cristianos de izquierda, lo pertinente para fines del estudio es señalar que las CEB contribuyeron a la consolidación del movimiento poblacional capitalino de dos maneras. Por un lado, ampliaron la agenda y cultura política de los liderazgos barriales, promoviendo la solidaridad entre las organizaciones, un nuevo discurso contestatario al poder y crítico ante las desigualdades humanas del sistema y con ejemplos prácticos de ética y transparencia en la gestión de los recursos y las reivindicaciones poblacionales que en la tradición clientelar barrial eran renovadoras.

Por otro lado, formaron algunos de los cuadros políticos y nuevos liderazgos que se proyectarán en los siguientes años en el movimiento poblacional quiteño, pues numerosos contingentes de jóvenes, hombres y mujeres se formaron, capacitaron y entrenaron en el activismo solidario eclesial, desempeñándose como los operadores políticos que vinculaban al movimiento poblacional con las luchas populares más amplias de los obreros, campesinos, indígenas y afrodescendientes en el país.

Asimismo, a la consolidación del movimiento poblacional capitalino también contribuyó, aunque de modo efímero, la militancia de los siete movimientos y partidos de izquierda que estaban activados en torno al movimiento obrero y que, en dichos años, experimentaba una sensación de frustración ante el reflujo de la lucha sindical y la retirada de las centrales sindicales. La joven militancia de izquierda, con vocación por cimentar articulaciones con los movimientos sociales, consideraba la efervescencia organizativa y la movilización poblacional de 
las tomas de tierras con que se formaban los barrios periféricos como un escenario alternativo a la crisis sindical, en el que se podía replicar la experiencia organizativa asimilada en el sindicalismo. Suponía que en el contexto barrial había condiciones apropiadas para reimplantar el "centralismo democrático", que no era sino una modalidad del verticalismo en las relaciones bases-dirigentes generalizado entre los partidos de izquierda.

El imaginario organicista de la izquierda se avivó con el aparecimiento de las federaciones barriales. Su militancia se involucró con el despegue de algunas de ellas y buscó montar una formación piramidal con comités barriales en la base, enlazados a las OSG y estas representadas en una instancia nacional. La ilusión ante una potencial configuración de relaciones orgánicas en el movimiento poblacional les llevó a tratar de reactivar el fallido Frente Nacional de Pobladores que, afiliado a la Confederación Ecuatoriana de Organizaciones Clasistas (CEDOC), se había creado quince años atrás. Más fue el deseo que la realidad, pese al activismo desplegado, apenas lograron que algunos dirigentes sindicales se relacionaran con el movimiento barrial.

Como lo señaló Borja (2011), si bien avalados por su experticia operativa en la lucha sindical y campesina, la militancia de izquierda se vinculó subordinadamente al movimiento barrial, sus actividades aunque oportunas estaban confinadas al activismo educativo, comunicacional y de animación en los comités y federaciones barriales; no tuvieron acceso ni influencia en las decisiones del movimiento poblacional que estaba circunscrita a los minúsculos círculos de las dirigencias y sus allegados.

La réplica organizativa de la izquierda en los barrios se frustró. Lo aprendido en las lides sindicales no tenía cabida en las luchas barriales, la deseada organicidad poblacional de la militancia de izquierda chocaba con el clientelismo de la dirigencia barrial. El ensamble organizativo de las luchas barriales se hacía, pragmáticamente, en el día a día de la toma de tierras, de la regularización de los barrios y de las presiones de sus habitantes por los servicios e infraestructura, mas no siguiendo los preceptos de una ideología vanguardista propia de la organización celular que proclamaba la izquierda. 
No obstante, durante casi una década, desde mediados de los años 80 hasta mediados de los años 90, la militancia de izquierda se volcó de lleno en el activismo con el movimiento poblacional. Apoyaba las asambleas y tomas de tierras, impulsaba la capacitación socioorganizativa de los pobladores, promovía la comunicación y educación popular con revistas y periódicos barriales en los que se debatía la política urbana y prestó el soporte político a las movilizaciones de las federaciones barriales (2011). La militancia de izquierda, sin un horizonte estratégico claro, intervino en el período de mayor expansión organizativa, coadyuvando a la consolidación del movimiento poblacional quiteño, durante el que formó políticamente a algunos de los cuadros y líderes de las organizaciones barriales y proveyó el activismo necesario con el que las federaciones barriales disputaban en el espacio público capitalino los derechos urbanos de los barrios periféricos.

A comienzos de los años 80 , en plena vorágine de las tomas de haciendas, de las movilizaciones y asambleas poblacionales en los terrenos recién ocupados, el PSP con auspicio de la CEDOC, indujo cuatro tomas de haciendas: al suroeste La Inmaculada, que dio origen al barrio La Ecuatoriana; al sureste Puengasí, donde surgió el barrio Futuro Libre; al suroeste San Luis de Chillogallo, que formó el barrio del mismo nombre; y en el flanco suroriental las haciendas Santa Ana y La Argelia, las más grandes de la zona, que dieron origen a la Cooperativa Lucha de los Pobres (102). Autodefinida como OSG, con cuarenta barrios periféricos conformados en su mayoría por inmigrantes empobrecidos, arrendatarios de los tugurios del centro, obreros de la construcción, trabajadoras domésticas, en general por población en condición de informalidad y desempleo, los moradores de la Cooperativa Lucha de los Pobres eran una muestra de los más desposeídos y excluidos de la ciudad (Burwal 1999, 169-70).

En medio de la precariedad de sus ocupantes, la Lucha de los Pobres se propuso como un "modelo de ciudad planificada de los pobres" que incluía espacios comunitarios, lugares para la cultura, salud, mercado, enmarcados en una suerte de propiedad de bienes comunes, organizándose el territorio en distritos y manzanas, con representaciones a 
una asamblea general en la que se ejercía la democracia directa. Animada por la joven militancia socialista, la Lucha de los Pobres se mantenía en constante movilización política en solidaridad con las causas obreras y campesinas, huelgas nacionales, marchas del primero de mayo y con las luchas del movimiento poblacional en la ciudad. Para sostener semejante efervescencia social, la dirigencia socialista demoraba la entrega individual de los títulos de los lotes (Borja 2011, 102), hasta que la situación se volvió incontenible por los cambios de la coyuntura política y las presiones internas de los dirigentes imbuidos por el pragmatismo barrial.

Tras seis años del inicio de un proyecto popular alternativo, los dirigentes barriales tomaron el control de la cooperativa y desplazaron al PSP, se alinearon clientelarmente con los partidos políticos que controlaban el municipio capitalino y el Gobierno nacional, poniéndose en tensión la "ideología clientelar y la ideología de protesta" supieron combinar para el logro de sus objetivos una "mezcla de patronazgo y protesta” (Burwal 1999, 178-83), diluyéndose el carácter innovador de la Cooperativa Lucha de los Pobres. Concuerdo con la apreciación de Burwal de que esa experiencia barrial vivió un acelerado lapso de auge y desactivación, sin embargo de lo cual, se proyectó como un emblema de dignidad de los excluidos de la ciudad.

En 1986, en el flanco suroriental de la ciudad, se formó el Frente de lucha por la reubicación de las envasadoras de gas. La Asociación de Barrios del Sur, la Federación de Barrios del Suroriente de Quito y veinticinco barrios periféricos sureños protagonizaron largas jornadas de protestas, bloqueos de calles, marchas ante las autoridades municipales y gubernamentales, campañas radiales y de prensa, dilatados trámites jurídicos en las instituciones públicas y tomas de las instalaciones exigiendo la reubicación de las empresas envasadoras de gas, que desde 1970 se asentaron en la zona de San Bartolo y que con el crecimiento urbano se encontraban rodeadas por los nuevos barrios periféricos, a su vez, afectados por los riesgos permanentes de contaminación, explosiones, estibaje, fugas y accidentes (Varea, Barrera, Maldonado 1997).

Luego de varios años de presiones poblacionales, ambigüedades municipales y coerción empresarial, las organizaciones barriales obtuvieron logros parciales. Pese a su clausura, las empresas se mantuvieron 
en el mismo lugar realizando las actividades de estibaje, funcionando como centros de acopio y distribución, y el envase de gas se trasladó a El Beaterio, lugar establecido por el municipio para actividades de alta peligrosidad, donde las tres empresas privadas y una estatal debían construir un cinturón de seguridad de 500 metros alrededor de las cuatro plantas, accesos con vías asfaltadas y edificaciones técnicamente adecuadas, lo que implicaba la expropiación de los terrenos y viviendas en las áreas circundantes en las que también estaban asentados numerosos barrios periféricos.

La inmediata oposición de sus habitantes activó el nuevo Frente de Lucha por la Vida de los Barrios del Sur. A los anteriores protagonistas se sumaron otros barrios periféricos, reeditándose las protestas, bloqueos de calles y carreteras, aberturas de zanjas y tomas de instalaciones, nutridas marchas hacia el centro de la ciudad, campañas radiales y de prensa, presiones y trámites ante las máximas autoridades legislativas, contenciosas, ambientales, municipales y gubernamentales; escalando el conflicto al involucrarse varias organizaciones ambientalistas, la UCE, los sindicatos de las fábricas del sector, las centrales sindicales, la Confederación de Nacionalidades Indígenas del Ecuador (CONAIE), la Comisión de Defensa de los Derechos Humanos y Amnistía Internacional (Varea, Barrera, Maldonado 1997, 73). Aunque el conflicto adquirió el carácter de problema de la ciudad y, como tal, el municipio buscó sin resultados la reubicación de las plantas envasadoras de gas, los barrios sureños lograron frenar la amenaza de expropiación de sus terrenos y viviendas, desactivándose el conflicto y la desmovilización de la población.

A fines de los años 80 la Federación de Barrios del Suroccidente, la Federación de Barrios del Suroriente y la FBNOQ confluyeron en la lucha contra el proyecto denominado Ley Cordón Verde que, auspiciado por el municipio y liderado por un representante del sector inmobiliario, pretendía fijar como límite de la cota de servicios urbanos a la avenida Occidental, excluyendo de un plumazo a todos los barrios ubicados arriba de dicha avenida.

El proyecto de ley elaborado con base en el enfoque metropolitano que fijaba los límites urbanos según la cota de servicios urbanos, 
aunque ambientalmente se mostraba adecuado en tanto establecía un tope a la expansión urbana y conservaba una franja de protección de los bosques en las laderas del Pichincha, socialmente era excluyente porque condenaba a la marginación urbana a todos los barrios periféricos que se habían asentado encima de la avenida occidental, en las laderas noroccidentales de la ciudad.

Apoyadas por el activismo de izquierda, las tres federaciones y los barrios periféricos del noroccidente protagonizaron masivas movilizaciones al Congreso Nacional y al municipio de Quito, exigiendo la no aprobación del mencionado proyecto de ley; emprendieron campañas de radio y prensa en las que denunciaban a la opinión pública la marginación que provocaría en los barrios quiteños, realizaron tomas de las calles de acceso a los barrios y bloqueos en la avenida Occidental, en las que, junto con las proclamas poblacionales por la defensa barrial, se agregaban las consignas radicales de la militancia de izquierda.

Los barrios periféricos ganaron la lucha contra ese proyecto de ley, el que fue archivado, y lograron su regularización en el municipio. Algunos agentes del mercado inmobiliario igualmente salieron beneficiados, ya que los servicios se expandieron a las lujosas urbanizaciones, centros comerciales y negocios inmobiliarios ubicados en la misma franja noroccidental. La cota de servicios urbanos se amplió, siguiendo el irregular emplazamiento de los barrios periféricos en las laderas del Pichincha. Con el triunfo, las federaciones se legitimaron en su rol de defensoras de los barrios periféricos, ante las organizaciones barriales y frente al municipio capitalino.

El movimiento poblacional quiteño se expandía, las organizaciones barriales continuaban incrementándose en número y nutriendo a las federaciones barriales. A comienzos de los años 90, según un estudio de la organización barrial (Barrera 2001, 23), se estimaba que las organizaciones barriales existentes en la capital eran alrededor de 760, las que equivalían al 24,3\% de las 3160 organizaciones sociales de Quito, y se habían legalizado y registrado en las distintas dependencias ministeriales.

En un ambiente proclive a la propagación de las luchas poblacionales, el 28 de mayo de 1990 un nutrido grupo de activistas de las CEB, 
de la militancia de izquierda - algunos directamente vinculados con el movimiento barrial capitalino- y de las organizaciones populares de seis provincias de la Sierra ocuparon la iglesia de Santo Domingo, exigiendo la resolución de 72 conflictos de tierras (Becker 2015). Un hecho inédito y ajeno a las luchas barriales.

Era el preámbulo del levantamiento indígena del Inti Raymi protagonizado por la CONAIE que, en junio de 1990 y tras la toma de Quito, irrumpió en el espacio público con intensas protestas callejeras, exigiendo la resolución de los conflictos agrarios, varias reformas económicas, la institucionalización de la educación bilingüe intercultural y el reconocimiento de Ecuador como un Estado plurinacional (38). El levantamiento indígena representó un hito trascendental en las luchas populares del país, pues los pueblos indios se posicionaron en el centro del escenario político como actores importantes de los asuntos nacionales.

$\mathrm{Al}$ poco tiempo se reunieron en Quito los representantes de numerosos pueblos y organizaciones indígenas de las Américas, en la Primera Conferencia Continental sobre los Quinientos Años de Resistencia Indígena, con el propósito de formar un frente común contra la opresión, la discriminación y la explotación exigiendo la autodeterminación de los pueblos, la autonomía indígena, el ejercicio del derecho consuetudinario y el reconocimiento de la justicia indígena en las comunidades. Asimismo, en abril de 1992, llegaron a Quito diez mil manifestantes indígenas que se incorporaron en el trayecto de la caminata iniciada desde el Puyo, emprendida por la Organización de Pueblos Indígenas de Pastaza (OPIP), exigiendo el reconocimiento de sus territorios, la protección de los bosques amazónicos, el desarrollo de la cultura, idioma, leyes y el Estado plurinacional (42).

En junio de 1994, nuevamente, la CONAIE emprendió las “movilizaciones por la vida” en contra de las políticas neoliberales, que buscaban sacar al mercado las tierras comunales ganadas con las reformas agrarias, la privatización del agua, la venta de tierras estatales y la intensificación de las exportaciones agrícolas (45). Ante la indiferencia gubernamental a las demandas indígenas, recrudecieron las manifestaciones de los pue- 
blos indígenas y sus coaliciones aliadas que bloquearon carreteras, marcharon hacia la capital y paralizaron al país durante diez días.

Se trató de un ciclo de levantamientos que evidenció la fuerza y capacidad asociativa del movimiento indígena, pues, apoyado por unas pocas coaliciones de sectores no indígenas, protagonizó acciones contestatarias con sus propios recursos, organizaciones y redes. No estableció conexiones con el movimiento poblacional capitalino, por lo que no era de esperarse que este se sumara a las manifestaciones de los indios en Quito. Sus irrupciones en los espacios públicos de la capital sorprendieron a las organizaciones barriales, que se mantuvieron pasivas ante los desenlaces de las protestas de los pueblos indios en la ciudad; voluntariamente, solo unos pocos comités barriales localizados en las entradas de la urbe se solidarizaron con las marchas indígenas y pequeños grupos de pobladores involucrados en los circuitos del activismo eclesial de base y la militancia de izquierda participaron en las manifestaciones callejeras indígenas.

La apatía de la mayoría del movimiento poblacional quiteño con los levantamientos indígenas no obedeció a deliberadas desconexiones entre sus respectivas dirigencias o a eventuales incomunicaciones de sus operadores, sino al predominio de una práctica autorreferida de las organizaciones barriales, volcada en el pragmatismo de las luchas por la vivienda, estas últimas poco politizadas con las causas de otros sectores populares. Evidenciaba el encapsulamiento del movimiento poblacional en su agenda popular urbana, y el desinterés de la mayoría de organizaciones barriales de involucrarse en otras causas que estaban por fuera de sus demandas de tierra, vivienda, servicios e infraestructura.

Revelaba que la fuerza adquirida por las federaciones, pese a los discursos de sus dirigentes, no rebasaba los perímetros zonales de los barrios periféricos y que los intereses terrenales de los pobladores delimitaban sus acciones. Fue una señal prematura de que el movimiento poblacional quiteño había llegado a la cima de sus luchas, que se iniciaba el descenso en las movilizaciones y el distanciamiento entre los discursos de las dirigencias federativas y los requerimientos pragmáticos de los habitantes de los barrios periféricos. 
Apartadas y en paralelo con las luchas indígenas, algunas de las federaciones barriales y organizaciones poblacionales habían establecido su prioridad local: buscaban incidir en la LRDMQ. En una actitud de puertas cerradas y sin ninguna disposición al diálogo con la ciudadanía quiteña o de consulta a la población de la ciudad, el Concejo Municipal, liderado por el alcalde, emprendió el debate sobre la normativa metropolitana, que fue aprobada en el Congreso Nacional en 1993. Pese a la trascendencia del cuerpo normativo en la vida de la ciudad, especialmente por los cambios en el modelo de gestión y en la estructura organizativa municipal, analizados en el capítulo anterior, las autoridades de la ciudad, en una franca actitud elitista, procedieron de modo vertical a su formulación y posterior aplicación.

Las federaciones barriales levantaron varias propuestas de democracia directa, especialmente para la designación de las autoridades de las administraciones zonales, las que previamente se habían analizado en un foro urbano facilitado por el Centro de Investigaciones CIUDAD en el que participaban las federaciones, organizaciones barriales, oenegés y personas interesadas en la temática. La actitud del alcalde fue de total indiferencia con las propuestas de las federaciones barriales, aunque de simbólica apertura para algunos de los comités promejoras de los barrios periféricos del sur conectados a la red clientelar de la DP, al que el burgomaestre pertenecía.

Las federaciones barriales tenían como referencias de sus reflexiones las experiencias en las ciudades vecinas de Medellín y Lima, y asumieron como perspectiva de su proyecto la descentralización metropolitana. Basadas en sus aprendizajes de la lucha barrial, comprendían la desproporción espacial que había entre la ciudad y los barrios, con lo que las aspiraciones de hábitat popular enunciadas desde el localismo de los barrios periféricos eran complejas de conseguir si no se modificaba la gestión de la ciudad a favor de las autonomías dentro de ella, como lo señala el testimonio de uno de los dirigentes barriales que intervino en los debates del proyecto de ley metropolitano:

En los barrios se planteaba que el Municipio se descentralice, no se desconcentre sino que se descentralice, que haya municipios más pequeños, 
donde se puedan generar las obras, se pueda organizar mejor la gestión, porque la ciudad resultaba muy grande para los barrios, demasiado grande para pensarla y para gestionarla: la ciudad es muy grande y los barrios son muy chicos. (Alvarado 2014, entrevista personal)

Plantear la descentralización municipal como parte de la ley metropolitana significaba posicionar el debate sobre la gestión de la ciudad en las fronteras de la reforma estatal. La creación de municipios menores implicaba modificar la organización territorial del Estado y alterar la conformación política-administrativa de la capital del país asentada tradicionalmente en un solo cantón, lo que es condición estructural de la heterónoma relación política entre el poder local quiteño y el centralismo estatal. Denotaba, aunque ese no era el propósito de las federaciones barriales, subvertir el orden de prelación del municipio quiteño. Las federaciones se inclinaron por una proposición de democracia directa como lo sostiene Javier Alvarado:

tenía que haber una propuesta más global que sea una sola política desconcentrada, pero sin perder de vista la participación de la comunidad, entonces se proponía que en las administraciones zonales tenga incidencia la comunidad en la designación de autoridades; por ejemplo: que se pueda hacer zonalmente una terna del partido que gane y se mande al alcalde para que escoja uno, o al revés, el alcalde hacía una terna con la gente de la zona de su partido y la mandaba a la zona para que se decida en una asamblea. (Entrevista personal)

Las propuestas de las federaciones barriales no tuvieron ninguna influencia en la formulación de la LRDMQ. Si bien sus argumentos estaban a tono con los debates regionales latinoamericanos sobre los procesos metropolitanos y en sintonía con las diversas corrientes de participación ciudadana que en esos años ya empezaban a caracterizar a los procesos de desarrollo local, sin embargo, no calaban en el ambiente y la cultura municipal capitalina. La democracia directa propuesta por las federaciones barriales para la designación de las autoridades en las administraciones zonales se mostraba precoz y ajena a las costumbres políticas quiteñas.

La LRDMQ fue aprobada al margen de las federaciones barriales y devino en la práctica, para los dirigentes barriales, en un dispositivo ad- 
ministrativo carente de contenidos socioculturales. No obstante, el debate político entre las federaciones barriales sobre la adopción del carácter metropolitano de la ciudad representó, discursivamente, un destello en el proceso público del movimiento poblacional quiteño, porque avizoró un horizonte estratégico de transformación urbana que condensó una visión compartida para la gestión de la ciudad, en la que se reconocía el peso relativo de los barrios periféricos. En el imaginario poblacional, la política urbana municipal podía asumirse en los barrios periféricos en condiciones de autonomía organizativa y participación ciudadana.

El atisbo de un horizonte de cambio en la gestión de la ciudad por parte del movimiento poblacional quiteño durante el debate, y luego con la inicial implementación de la LRDMQ, estimuló el autorreconocimiento de las federaciones y organizaciones barriales como "actores de una ciudad diferente". Conforme a la nueva normativa, el municipio delimitó y formó los primeros tres distritos: Norte, Centro y Sur, con sus respectivas administraciones zonales, ante lo cual las organizaciones barriales reconocieron que no cabía seguir con las mismas prácticas, pues "la ciudad había cambiado", tomaron conciencia de las modificaciones del contexto institucional que exigía nuevas "maneras de interlocución" ante las autoridades municipales, con lo que en octubre de 1995 confluyeron en el Encuentro de Organizaciones Barriales del Distrito Metropolitano de Quito.

En el encuentro se sistematizaron algunas experiencias y luchas del movimiento poblacional capitalino. Con la asistencia de numerosos representantes de las federaciones y comités barriales, oenegés aliadas y organizaciones populares declararon: "se vive un Quito diferente", es necesario "salir del exclusivo interés barrial y pensar con criterios de ciudad", pasar de la condición de "espectadores de las decisiones sobre nuestras vidas elaboradas por técnicos desde el escritorio", a constituirse en "sujetos de nuestro propio desarrollo y no objetos de transformación” (FBPNQ y otros 1995, 3).

En el encuentro, entusiastamente, los pobladores concluyeron que más allá del intercambio de experiencias, al interior de los barrios, hay otros actores organizados, como los jóvenes y las mujeres, que no 
pueden seguir siendo solo "vocales de deportes o asuntos sociales", sino involucrarse en todos los aspectos de la vida barrial. Asimismo, al igual que en los barrios hay variedad de actores, la acción en la ciudad es mucho más compleja y demanda despojarse de la autorreferencia barrial, ya que si los problemas rebasan a los barrios, las "organizaciones no pueden seguir enclaustradas"; si quieren participar en las decisiones de la ciudad, requieren abrir nuevas esferas de diálogo, por lo que en el encuentro con otras organizaciones deben pasar de ser "demandantes de obras" a participar en las definiciones en torno a la ciudad que queremos vivir", sentenciaba la Memoria del Encuentro (39).

El encuentro entre los barrios periféricos ratificó que el movimiento poblacional quiteño había tocado su pináculo, porque nuevamente se evidenció el desfase entre un discurso avanzado de los dirigentes barriales y el pragmatismo de los moradores. Por un lado, los dirigentes de las federaciones levantaban proclamas de renovación organizativa y de participación en los asuntos de la ciudad; por otro, los pobladores continuaban aferrados a sus demandas materiales de infraestructura y servicios básicos. Mientras los dirigentes de las federaciones pensaban que el hábitat popular se podía construir en el marco de las definiciones de la política urbana de la urbe, los pobladores continuaban concentrados en la consecución de vivienda, calles, servicios y para conseguirlos estaban abiertos al clientelismo de los comités barriales. El imaginario poblacional había entrado en tensión con el realismo de los pobladores.

Dos años más tarde, las intensas movilizaciones sociales de las clases medias y altas quiteñas, motivadas por la "deshonra a la ciudad" de parte del Gobierno de Bucaram y que en 1997 provocó su derrocamiento - que analizaré en el cuarto capítulo—, se consumaron sin la intervención del movimiento poblacional capitalino, aunque ciertos segmentos de pobladores sí participaron activamente en las manifestaciones de rechazo a Bucaram en otras ciudades del país. De modo similar a lo ocurrido en los levantamientos indígenas, solo los dirigentes de algunas federaciones, el activismo eclesial de base y la escasa militancia de izquierda que quedaba en los barrios periféricos participaron en las manifestaciones callejeras. 
Nuevamente, en actitud pasiva, el movimiento poblacional contemplaba los acontecimientos turbulentos que vivía la ciudad. La "deshonra de la ciudad", a la que se refería la prensa y la opinión pública capitalina, no era algo que les incumbía dada su crónica segregación urbana, siempre tuvieron que movilizarse al municipio para conseguir las pocas obras en los barrios, por lo que la llamada del alcalde de la capital a levantarse contra el Gobierno no les convocaba. Las organizaciones barriales quiteñas, desmovilizadas, presenciaron el inevitable desenlace político.

En el fondo ocurrió que el movimiento barrial quiteño había entrado en una nueva fase de transición, en la que en un corto lapso se contrajo el protagonismo de las federaciones barriales y disminuyó la intensidad de las luchas poblacionales. Ya no era factible perpetrar las multitudinarias marchas de los habitantes de los barrios periféricos ni las manifestaciones callejeras de las federaciones barriales que, paulatinamente, perdían su capacidad de convocatoria interbarrial, ya que numerosos comités barriales se desafiliaban, y las agrupaciones juveniles, de mujeres y culturales, que tampoco habían encontrado cabida en las federaciones ni en los comités barriales, se movilizaban por su cuenta.

La segunda transición del movimiento barrial quiteño coincidió con el final del segundo período del alcalde Jamil Mahuad y la llegada de su reemplazo, Roque Sevilla, cuando el primero se postuló a la presidencia del país. Fueron años en los que empezó la desintegración socioorganizativa del heterogéneo mundo poblacional de los barrios periféricos, el que se había podido contener y encauzar con las federaciones, y que ahora, con estas debilitadas, se disgregaba. Las organizaciones barriales asistían a una metamorfosis de acciones contestatarias, pasaban de ser actores de la interpelación a la política urbana a sujetos del apaciguamiento de las luchas barriales. A finales de los años 90 unas pocas federaciones barriales subsistían disminuidas, los comités barriales se habían desconectado de la geografía a la que simbólicamente se habían adscrito y las agrupaciones poblacionales se estaban disgregando.

Vista en referencia con el proceso general de formación y ascenso del movimiento barrial quiteño, esta segunda fase de transición, a diferencia de la anterior que en sentido escalonado modificó su repertorio 
de acción colectiva, iba en sentido regresivo, ya que de la intensidad en las luchas barriales se pasó al repliegue del movimiento barrial. En la conversión se enlazaron tres factores coadyuvantes: la retirada de la militancia de izquierda, la crisis de los partidos políticos y el desgaste de las propias organizaciones barriales.

La retirada de la militancia de izquierda del movimiento poblacional fue parte de las repercusiones locales de la "caída del muro", que agudizó el congénito divisionismo ideológico de los grupos de izquierda y la confusión sobre su rol vanguardista. A mediados de los años 90 la militancia de izquierda migró, por así decirlo, desde el movimiento poblacional hacia la institucionalidad político-electoral, estuvo en tránsito por el movimiento indígena y el sindicalismo público que había experimentado un vertiginoso incremento organizativo, y luego abandonó la causa de los movimientos sociales para dedicarse por entero a la política electoral, curiosamente en el momento de mayor desgaste de los partidos políticos. La partida de la militancia de izquierda del movimiento poblacional significó la pérdida de activistas organizadores, recursos tácticos y operadores políticos que en buena medida sostenían las acciones colectivas de las federaciones barriales, las que huérfanas de comunicación, capacitación y apoyos metodológicos disminuyeron notoriamente su capacidad de movilización.

El descrédito de los partidos políticos se evidenció desde el ascenso de Bucaram y continuó en los siguientes años, en los que proliferaron variopintos acuerdos, uniones y componendas partidarias hechas únicamente con el latrocinio propósito de saquear los recursos públicos, y precipitaron el desgaste del sistema de representación, especialmente en la capital devenida en el mayor escenario del pillaje partidario. En los barrios periféricos las maquinarias electorales removían sus redes clientelares en función de fugaces coaliciones electorales, provocaban la desafiliación de los comités barriales de las federaciones y su confuso alineamiento en los microcircuitos de caciques y dirigentes barriales, devenidos en permanentes candidatos de las distintas tiendas electorales.

La crisis de los partidos políticos minaba al movimiento poblacional quiteño, socavaba sus bases organizativas y acentuaba las lealtades 
patrimoniales en los comités barriales, distanciándoles de los avances logrados en torno a los bienes comunes. La decadencia de los partidos políticos arrastró a un movimiento poblacional secularmente trabado con el clientelismo político local.

El desgaste interno de las federaciones y de los comités barriales ha sido y es una constante del movimiento barrial capitalino: tienden a una vida efímera, una vez que consiguen sus propósitos, las obras físicas o las demandas que los motivan se desactivan. La mayoría de las federaciones barriales se formaron para asegurar la tierra urbana y la defensa de los barrios periféricos, una vez conseguida la tierra y regularizados algunos de los barrios, estas empezaron un camino de desactivación hasta que muchas se extinguieron.

$\mathrm{Al}$ poco tiempo de la regularización de los barrios periféricos, algunos comités barriales también se separaron de las federaciones, unos emprendieron o retornaron a su propio camino y otros se disolvieron. Del mismo modo, se debilitaron las iniciativas de elaboración de planes de desarrollo barrial de carácter popular, se disolvieron las acciones unificadas de coordinación barrial y fueron vanos los esfuerzos de participación de los diversos sujetos poblacionales. La mínima acción colectiva de los barrios periféricos capitalinos, conseguida con grandes esfuerzos en el período de auge del movimiento poblacional, cedía el paso, nuevamente, al pragmatismo de los moradores que iba acompañado del verticalismo y personalismo de las dirigencias barriales.

Así, en la fase de transición entre mediados y fines de los años 90, el movimiento poblacional experimentó un descenso desde la cima de las movilizaciones federativas y zonales de los barrios periféricos hacia el repliegue de las luchas poblacionales y la desactivación de las federaciones barriales. La retirada de la militancia de izquierda que de todas maneras funcionaba como un dique que contenía al clientelismo político, la crisis de los partidos políticos que perforaba a las organizaciones barriales y el pragmatismo de las dirigencias que desgastaba a los comités barriales contribuyeron al declive del movimiento poblacional.

Las relaciones de los barrios periféricos con el municipio se atomizaban entrampadas en las redes clientelares. La agenda de hábitat po- 
pular, que había escalado hacia las federaciones y atisbó un horizonte innovador, se desplomaba con la disgregación de las reivindicaciones urbanas, y el encuentro en los espacios públicos del movimiento poblacional con otros actores populares se había enredado con la crisis político-institucional que se extendía en la ciudad. A finales de los años 90 se había consumado el repliegue del movimiento poblacional quiteño, evidenciándose el contrasentido entre las postreras movilizaciones barriales frente al ascenso de las luchas indígenas, que tenían como referencia semántica la toma de la capital del país, y a la efervescencia de las clases medias y altas quiteñas movilizadas en repudio al desorden político provocado por lo extraño.

\section{El declive: Dispersión organizativa y participación ciudadana}

El cambio de milenio o el paso del siglo XX al XXI fueron años convulsionados de afianzamiento del DMQ. La ciudad vivía un remolino de tensiones políticas entre fuerzas centrípetas locales, dinamizadas con la renovación y expansión urbana, y fuerzas centrífugas nacionales, activadas con el descrédito de las principales instituciones estatales. Entre los derrocamientos de los presidentes Bucaram, Mahuad y Gutiérrez, y hasta pasados la mitad de los años 2000, se exacerbaron los ímpetus bipolares propios del neoliberalismo, pues en paralelo con la desarticulación de la centralidad estatal y el descrédito del sistema de representación que se expresaban en toda su decadencia en el escenario público capitalino, se consolidaba localmente, con el distrito metropolitano, el triunfalismo criollo de las élites quiteñas. Los espacios públicos de la ciudad fueron sucesivamente copados por fuerzas sociales que, al tiempo que se movilizaban para los derrocamientos presidenciales, exhibían el éxito neoliberal del capitalismo criollo.

En un ambiente de crisis política el movimiento barrial quiteño, tras el desplome de las federaciones y el repliegue de las luchas poblacionales, desembocó en un tercer período caracterizado por la fragmentación de los intereses barriales en torno a la agenda de hábitat popular y por la continua dispersión de las organizaciones barriales. Al extinguirse las federaciones barriales, se erradicaron las iniciativas de agregación de 
los intereses interbarriales, se suprimieron las convergencias zonales de los barrios periféricos y se cerraron sus espacios de encuentro y diálogo interbarrial sobre la política urbana metropolitana.

Los comités promejoras, otrora vinculados por motivaciones compartidas, también comenzaron con una tendencia de disgregación enredados en las enmarañadas ramificaciones de los partidos políticos, grupos y coaliciones electorales, caciques locales, notables y caudillos barriales que constantemente superponían las maquinarias electorales a los comités barriales. Del mismo modo que después del paso de una ola del mar solo queda espuma en la arena, tras el auge de las luchas poblacionales, permaneció un manto uniforme de comités promejoras desperdigados en el desdibujado espacio público capitalino.

El lapso en que se agotó el movimiento barrial quiteño acaeció, discordantemente, en medio de la continua expansión urbana, del incesante aparecimiento de nuevos barrios periféricos y de la proliferación de comités promejoras. En una suerte de ironía urbana, el movimiento barrial quiteño se apagaba en el momento de mayor multiplicación de barrios periféricos y comités promejoras. El tercer período empezó desde comienzos de los años 2000, y se prolongó hasta entrada la segunda década de los años 2000, sin que haya señas visibles de una nueva fase de transición en la que se revirtiera la tendencia dispersante de las organizaciones barriales. El tercer período del movimiento barrial comprendió las dos alcaldías de Paco Moncayo, entre 2000 y 2009, auspiciado por la ID, y continuó en las siguientes alcaldías.

Durante esos años, Quito acentuó su expansión metropolitana hacia las zonas agropecuarias circundantes, cercando a los poblados y parroquias rurales, presionando a los cantones vecinos, los dos más cercanos, Mejía y Rumiñahui, convertidos en "ciudades dormitorio" y dedicados a resolver las demandas de infraestructura, servicios, equipamiento y movilidad provocadas por la expansión metropolitana; mientras los cantones de Cayambe y Pedro Moncayo se consolidaron como zonas de agroexportación. A la vuelta de pocos años, la trama urbana de la capital incorporó territorios anteriormente desparramados en la geografía cantonal, enlazándolos como zonas administrativas del complejo 
institucional de nuevas centralidades financieras, comerciales y residenciales esparcidas, a la vez acopladas, en la gestión municipal del distrito metropolitano. En el transcurso de los tres primeros lustros de asunción de la condición metropolitana, el territorio de la ciudad capital se expandió en casi tres veces su tamaño.

Concomitantemente, los barrios periféricos de Quito metropolitano también aumentaron y se diversificaron. Su número se incrementó de 190 barrios irregulares a finales de los años 90, a 280 barrios irregulares a mediados de los años 2000 (Cuenin y Dávila 2009, 241) y a 523 barrios irregulares al año 2011 esparcidos en la periferia urbana, aunque aglomerados en tres administraciones zonales: el 46,40\% de los barrios irregulares se localizan en Quitumbe, el 14,90 \% en Calderón y el 14,70 \% en La Delicia (MDMQ 2012, 67).

El aparecimiento de nuevos barrios periféricos y populares no se limitó al perímetro urbano, pues con la expansión metropolitana de la ciudad sobre las parroquias rurales surgieron nuevos asentamientos humanos y barrios irregulares en la mayoría de las 33 cabeceras parroquiales y centros poblados rurales. Basado en el registro de organizaciones de vivienda del MIDUVI (2015), estimo que en el período se adicionó un aproximado de noventa nuevos barrios irregulares en las parroquias rurales, con lo que el total de asentamientos humanos puede estar en alrededor de los 613 barrios periféricos en todo el distrito metropolitano.

Hay lugares en los que la densa trama urbana metropolitana desdibuja las distinciones entre el campo y la ciudad; eso acontece en las parroquias rurales de Calderón, Pomasqui, Nayón, Tumbaco, Cumbayá y Conocoto, donde son tupidas las penetraciones urbanísticas con nuevas lotizaciones y ciudadelas, las conversiones de pequeños poblados en barrios, especialmente de comunas campesinas que se tornan en barrios periféricos sin servicios y los conurbanos residenciales/periféricos de las cabeceras parroquiales. En estas franjas se configuran nuevas tramas urbanas que ensanchan a la ciudad, las que albergan cuantiosos contingentes de habitantes, barrios periféricos y comités promejoras, aunque administrativamente sean consideradas como zonas rurales. 
El aumento de los barrios periféricos es parte de los cambios en la estructura demográfica de la ciudad. La población total del DMQ a 2010 fue de 2239191 habitantes: el 72 \% es urbana (1 619 146), y el 28 \% es rural (620 045); el 49,1 \% de la población quiteña vive en el área consolidada de la ciudad y el 50,9 \% vive en las áreas en proceso de consolidación. Hay una propensión a la disminución de la tasa de crecimiento de la población capitalina: del 2,6 \% en 2001 bajó al 2,2 \% en 2010; en el área urbana pasó de $2,2 \%$ a 1,5 \%, y en el área rural de 4,8 \% a 4,1 \% en los mismos años (MDMQ 2012, 14).

En la urbe predomina la población joven, en tanto disminuye la tasa de crecimiento de la población infantil en 1,8 \%, y aumenta la tasa de crecimiento de jóvenes y adultos en 1,7 \% (15). Igualmente, se contrajo el tamaño de la familia, que en 1980 era de 4,62 miembros, en 1990 disminuyó a 4,23 miembros, en 2001 a 3,76 miembros y en 2010 a 3,49 miembros (63).

En diez años la población del distrito aumentó en más de 400 mil nuevos habitantes, en proporciones similares en las áreas urbanas y rurales, pues 206 mil nuevos habitantes son urbanos y 193 mil son rurales (Instituto de la Ciudad 2012, 24). De los 237 mil nuevos habitantes registrados entre 2005 y 2010, el 68 \% inmigró al DMQ y el 32 \% nació en Quito, con lo que de las 161 mil personas que llegaron al distrito, el $24 \%$ se estableció en la zona rural y el $76 \%$ en la zona urbana.

Más allá de las distinciones de origen y destino de los flujos migratorios, el $78 \%$ de los migrantes al DMQ son de origen urbano, y se debe, según el análisis del Instituto de la Ciudad, a la búsqueda y esperanza de obtener mejores condiciones de vida, empleo, habitabilidad, educación universitaria y ascenso social en la ciudad capital, que en los últimos veinte años redujo significativamente las brechas en el acceso a servicios: a 2010 el agua por tubería llega al $75 \%$ de los hogares rurales y al $87 \%$ de los urbanos, el alcantarillado sanitario cubre al $75 \%$ de las viviendas rurales y al $96 \%$ de las urbanas, y la cobertura de energía eléctrica alcanza al $65 \%$ de los hogares rurales y al $99 \%$ de los urbanos (24-5).

Estos cambios se conocen como "transición demográfica", la que, a más de ser un signo de la irreversibilidad de la modernidad urbana, 
conforma el piso social de los comportamientos disgregados frente a los requerimientos de hábitat popular de los habitantes de los barrios periféricos. La tendencia a la urbanización de la población refuerza los valores liberales del individualismo moderno en las nuevas generaciones de habitantes de los barrios periféricos, subvalorándose los esfuerzos colectivos de sus antecesores con los que se conformaron los barrios periféricos (Ortiz y Martínez 1999, 348). De ahí que en los barrios periféricos se den incógnitas inserciones individuales de sus habitantes en la ciudad, a costa del debilitamiento generalizado de los vínculos colectivos, cooperativos y solidarios, afianzándose los comportamientos privativos.

El otrora colectivismo vecinal, con el que se asumía la presión social por la agenda de hábitat popular, fue sometido por el individualismo organizativo enfocado en la propiedad privada de la vivienda, quedando en un pasado en el que rápidamente se desvanece la memoria de las luchas por los servicios y equipamientos barriales; en sincronía, la mayor preocupación organizativa de los moradores se redujo a asegurar el perímetro minúsculo de su vivienda, tal como sucede en los demás lugares consolidados y residenciales de la ciudad (Unda 2014). En los barrios periféricos las prácticas organizativas terminaron subordinadas al individualismo rampante: las decisiones compartidas se desvanecieron, las iniciativas comunitarias se "descomunalizaron" y el apoyo a las movilizaciones devino en impasibilidad.

En la vida cotidiana de los habitantes de los barrios periféricos las relaciones de solidaridad, afinidad y cooperación son necesarias para enfrentar y asumir las actividades económicas, sociales y culturales en los ámbitos familiar, vecinal y urbano que permitan la reproducción material y social de la población. Los espacios colectivos son constitutivos de sus estrategias de sobrevivencia, los que se resguardan resisten al avance del individualismo liberal. Es en el plano organizativo donde se experimentan los retrocesos colectivos y el sometimiento al individualismo liberal, exaltándose la perspectiva personalista de los derechos ciudadanos.

El desplazamiento del interés colectivo al interés individual es parte del proceso de conversión de los pobladores en ciudadanos, aunque esta no consiga que todos los moradores de los barrios periféricos 
sean propietarios de vivienda, ya que en Quito es persistente el déficit de vivienda: en el año 1990 era de 44 \%, en 2000 bajó al 42 \%, y en 2010 llegó al $39 \%$, siendo la única ciudad ecuatoriana en la que hay más viviendas en arriendo que viviendas en propiedad (MDMQ 2012, 65).

La conversión en ciudadanos tampoco asegura suficiente equidad de sus habitantes, aunque en la erradicación de la pobreza estructural se han dado significativos avances en la ciudad, la que pasó de un total de pobreza de 22,2 \% en 2000 al 12,8 \% en 2010; en el área urbana del distrito bajó de $19,9 \%$ en 2000 a 11,2 \% en 2010; en el área rural de 30,1 \% a $17,3 \%$ en los mismos años; el total de extrema pobreza igualmente bajó de 8,2 \% en 2000 a 2,3 \% en 2010; en el área urbana bajó de 6,9 \% a 1,7 \%; en la rural descendió de $15,3 \%$ a $4,1 \%$ en el mismo período (13). No obstante, persiste en la ciudad una pobreza dura, en cifras absolutas la población pobre en Quito a 2010 son 360399 personas: 238698 en el área urbana, 123701 en el área rural; mientras el total de la población en extrema pobreza en el distrito son 71040 personas: 39518 en el área urbana, 31522 en el área rural (13).

El discurso de los derechos ciudadanos, que se había configurado paulatinamente y de modo sectorial en años precedentes, se consolidó en la sociedad capitalina durante los años 2000, difundiéndose ampliamente entre los distintos estratos de la población, calando, incluso, en los barrios periféricos, cuyos dirigentes empezaron a asumir el enfoque de los derechos ciudadanos en sus gestiones por la agenda del hábitat popular. El discurso de los derechos ciudadanos siguió un complejo itinerario de ampliación y adopción en los países.

En 1950 T. H. Marshall declaró que las igualdades básicas de la ciudadanía en la democracia moderna pueden reducir o legitimar las desigualdades persistentes entre las clases sociales, dado que la ciudadanía está enfrentada a la lucha social, especialmente a la lucha de clases. Marshall identificó tres elementos de la ciudadanía moderna: el civil, que son todos los derechos necesarios que aseguren la libertad individual, la propiedad privada y la justicia; el político, que son los derechos a participar en la política y en el sufragio universal; y el social o los derechos que aseguren bienestar económico, seguridad y vida civiliza- 
da (Crompton 1994, 175-6). La conceptualización de Marshall influyó enormemente en la expansión occidental de la ciudadanía por medio de las sucesivas conferencias de las Naciones Unidas que institucionalizaron las agendas de derechos ciudadanos.

$\mathrm{Al}$ respecto, Hopenhayn sintetiza el proceso de ampliación de los derechos ciudadanos. En la perspectiva liberal demócrata, dice, la ciudadanía se tradujo como derechos civiles de primera generación o libertades propias del Estado de derecho, y apuntan a proteger la autonomía individual frente a la coacción estatal; luego los derechos políticos o de segunda generación, referidos al derecho ciudadano a elegir las autoridades y participar en el sistema de gobierno. En la perspectiva socialdemócrata la ciudadanía se amplió a derechos de tercera generación o derechos económicos, sociales y culturales que incluyen los derechos al trabajo, salud, educación, ingreso digno, vivienda adecuada y el respecto a la identidad cultural. Finalmente, en la perspectiva republicana la ciudadanía se asocia con mecanismos y sentidos de pertenencia del individuo a una comunidad o nación, a la participación en la "cosa pública" y en la definición de proyectos de sociedad $(2001,118)$.

El ejercicio de los derechos ciudadanos no supone la imposición de acciones específicas, sino pautas de obligaciones, una suerte de orientaciones que dejan espacios de discrecionalidad para que el Estado y los sujetos tomen las medidas adecuadas que permitan el logro efectivo de los derechos ciudadanos, los que a su vez conllevan obligaciones positivas y negativas, explica Abramovich (2006). Los derechos ciudadanos, además de normas, conllevan acciones de exigibilidad.

Las diferencias entre los distintos derechos "son de grado y no de sustancia", comportan obligaciones estatales de hacer y de no hacer, una trama de alcances positivos y negativos del Estado para respetar, proteger, garantizar y promover los derechos ciudadanos, por lo que el "catálogo" de derechos civiles, políticos, económicos, sociales y culturales tiene un "valor heurístico, clasificatorio"; afinando su comprensión, se trata más bien de un continuum de derechos ciudadanos, diferenciados por sus simbolismos en las obligaciones positivas o negativas que conllevan (42), cargados de valores prescriptivos. 
Los períodos de despegue, auge y decline del movimiento barrial capitalino testimonian que los derechos ciudadanos al hábitat popular se conquistan, se negocian, no son legados estatales ni atributos naturales de los sujetos populares, y que, en la medida en que se amplía la dimensión social de la ciudadanía, se tiende a atenuar el conflicto social. Del mismo modo que en la cotidianidad de la vida vecinal el individualismo sometió a lo colectivo, en el fraccionado espacio público capitalino hizo mella el expansivo discurso de la ciudadanía: la creciente ampliación de los derechos de tercera generación y de adscripción identitaria, en su diversidad cultural y pluralidad ideológica se superpuso, por entero, a la narrativa poblacional como semiótica movilizadora. Los derechos ciudadanos terminaron de desplazar al discurso poblacional como referente y horizonte de las organizaciones barriales entrados los años 2000.

En sintonía con estos desplazamientos narrativos, una de las primeras ordenanzas del alcalde Paco Moncayo fue poner en vigencia un dispositivo público de participación ciudadana en el DMQ, con el propósito de facilitar las relaciones y decisiones entre la población quiteña y las autoridades municipales. La Ordenanza Metropolitana 046, sustentada en principios de equidad, integralidad y democracia directa, estableció el SGP, que articulaba el gobierno local y la participación ciudadana en el ciclo de las políticas municipales, en ámbitos temáticos y territoriales, con cuatro niveles de participación: cabildos distritales, cabildos zonales, asambleas en las parroquias rurales y asambleas en barrios urbanos (Barrera 2001). Era una versión más avanzada del mandato originario de la normativa metropolitana que previó la participación ciudadana.

La mecánica operativa preveía que en los cabildos, como espacios públicos de participación, se debatan y jerarquicen las demandas ciudadanas que serían agregadas y convertidas en respuestas por el gobierno metropolitano; mientras en los cabildos distritales y zonales se formaban comités de gestión para el seguimiento a los compromisos municipales, y un Consejo de Equidad articulaba las demandas temáticas y territoriales en un Plan Social alineado con el Plan Siglo XXI y las directrices del Plan General de Desarrollo Territorial DMQ 2000-2020. 
En los primeros años de implementación del SGP se realizaron más de doscientos eventos participativos y se movilizaron aproximadamente diez mil personas en los cabildos temáticos y territoriales. Al principio las demandas jerarquizadas por la ciudadanía parecían posibles de agregación considerando que sus diferencias eran solo de escala, pero en realidad la participación movilizó actores y demandas distintas, dada la fragmentación de intereses y actores, la dispersión organizativa y la ampliación de los derechos ciudadanos. En los cabildos temáticos distritales convergieron las agrupaciones locales activadas en torno a los derechos sociales y culturales de niñez y adolescencia, población adulta mayor, población con discapacidades, grupos juveniles, pueblos indígenas en la ciudad, población afroquiteña y el movimiento de mujeres; mientras a los cabildos territoriales confluyeron los dirigentes de los barrios periféricos y las parroquias rurales portando listados de demandas relativas a los derechos a la vivienda (Torres 2008, 88-108).

$\mathrm{Al}$ igual que en el ámbito nacional del Estado es compleja la articulación de las dimensiones sectorial y territorial por las implicaciones institucionales y operativas, en el distrito metropolitano no fue sencillo acoplar en las políticas municipales los requerimientos temáticos de los participantes en los cabildos distritales, legitimados por la ampliación de los derechos sociales, con los requerimientos de los participantes en los cabildos zonales con reivindicaciones territoriales, igualmente legitimadas con el ensanchamiento de los derechos al hábitat popular.

El municipio debió recurrir a arreglos institucionales que conecten el abanico de demandas de derechos ciudadanos con el de por sí complejo aparato municipal metropolitano; como era de esperarse, las respuestas municipales fueron desiguales en las ocho administraciones zonales, aunque permitieron al municipio capitalino relacionarse mejor con la población de la ciudad. Durante varios años de su implementación los distintos colectivos sociales consiguieron algunos resultados que beneficiaron directamente a determinados segmentos de población e influyeron en el bienestar general, al tiempo que los barrios periféricos se favorecieron con obras priorizadas participativamente en los cabildos zonales. 
No es aquí el lugar para evaluar la experiencia institucional de participación social metropolitana, sobre la cual se dice que no logró mayores impactos — al respecto hay una bibliografía disponible-. Interesa destacar que la participación visibilizó la diferenciación de intereses entre los cabildos distritales y los cabildos zonales: mientras en los primeros se plantearon demandas sociales, culturales e identitarias de colectivos ciudadanos segmentados y autorreferidos, en los segundos se trataron las disgregadas demandas territoriales de los barrios periféricos y las parroquias rurales (89). La diferenciación de demandas sociales en los cabildos ratificaba la dispersión organizativa que experimentaban los barrios periféricos metropolitanos.

Más allá del balance de resultados en la provisión de bienes y servicios públicos del SGP, la participación tuvo un efecto pedagógico en el avance de los derechos ciudadanos en la sociedad quiteña, especialmente en los barrios periféricos, las parroquias rurales y en los grupos vulnerables. Asumida como un componente sustancial de las estrategias y políticas del gobierno metropolitano, la participación devino en un dispositivo público que permitió establecer necesidades, acordar prioridades y orientaciones para las intervenciones municipales en los ámbitos urbanos y rurales.

Buscó la incorporación, en la gestión pública local, de los sujetos sociales secularmente segregados, aquellos discriminados por la política urbana y con dificultades para ejercer algunos de los derechos ciudadanos, quienes generalmente habitan en los "barrios marginales", como todavía se los denominaba en la retórica municipal. Una condición para que eso suceda es la organización social, sin ella la participación, aunque colmada de buenas intenciones, tiene alcances limitados.

La participación se planteó como un derecho ciudadano que otorgaba poder a los sectores excluidos y segregados, siempre que se reconozca y ejerza la titularidad de los derechos como generadora de las obligaciones municipales ante la ciudadanía. Buscaba modificar el sentido de las políticas urbanas para convertir a las personas de portadoras de necesidades básicas insatisfechas en activos ciudadanos con derechos individuales y colectivos demandantes de bienes, servicios, prestaciones 
y conductas públicas. En esta conversión la organización social era un factor coadyuvante de las acciones colectivas que superen el acatamiento de las disposiciones formales, haciendo efectivas las obligaciones jurídicas, imperativas y exigibles derivadas de los derechos ciudadanos, pues estos demandan obligaciones, y las obligaciones requieren mecanismos para hacerlas exigibles y darles cumplimiento (Abramovich 2006, 36).

La puesta en vigencia del SGP coincidió con el período de dispersión organizativa y el repliegue del movimiento barrial capitalino, por lo que debió implementarse en medio de una meseta ideológica de individualismos, de protagonismos personalistas en busca de visibilidad y de organizaciones urbanas enredadas en las enmarañadas redes del clientelismo político. Los imaginarios urbanos quiteños, enrarecidos por la persistente crisis política, enaltecían el orden regulatorio del neocolonial modo de vida capitalino, que fue ratificado con los sucesivos desenlaces políticos, ante los que el debilitado movimiento barrial se mantuvo pasivo. El colapso de la centralidad estatal, la decadencia del sistema de representación y el repliegue del movimiento barrial caracterizaron el escenario metropolitano en el que se implementó la participación, aunque quisiera, esta no era ajena ni inmune a lo que acontecía en la ciudad. La participación aparecía como una suerte de intento de orden barrial en medio del desorden territorial metropolitano.

A las primeras convocatorias, en procura de establecer relaciones directas con la ciudadanía, respondieron los representantes de las agrupaciones sociales de derechos y las dirigencias barriales y parroquiales, confundiéndose de entrada los roles organizativos (Torres 2002): los cabildos fueron vistos como competidores de las organizaciones urbanas, rivalizaban con las juntas parroquiales rurales, se superponían a las pocas y debilitadas federaciones barriales y estimulaban los afanes de cooptación institucional de unos y los autonomismos de otros.

El brumoso escenario de relaciones participativas se fue disipando progresivamente, quedando en claro el predominio de los protagonismos individualistas y la fragmentación clientelar en los cabildos distritales y zonales, a costa de la erosión de las acciones colectivas. En adelante, el lugar de agregación de los intereses barriales y ciudadanos 
correspondía a las instancias municipales de participación, dejó de ser social para volverse municipal, pero por las limitaciones operativas de la institucionalidad encargada de su operación tampoco logró sostenerse como instancia pública de convergencia de los intereses populares, con lo que la participación se fue debilitando hasta subsistir residualmente en algunas de las administraciones zonales. Javier Alvarado explica en los siguientes términos el desgaste de la participación social convocada por el municipio capitalino:

Se perdieron de vista en el tiempo los objetivos de la participación, porque se vio que era muy complicado. Cuando se armó, los cabildos se convirtieron en espacios de petición de obras, la gente no iba a debatir, no iba a discutir temas de la ciudad, sino que era la oportunidad para pedir lo que necesitaban y se terminaba con una cosa abultada. No había espacios de discusión, de visión de la ciudad, ni tampoco una metodología que nos lleve a construir una visión, simplemente nos botaba a una lista de obras. Eso rebasó y después fue al revés, se llamaba a la gente para implementar las obras compartidas. (2014, entrevista personal)

El testimonio ilustra cómo las instancias municipales de participación social desnaturalizaron sus propósitos iniciales de promover la titularidad de los derechos ciudadanos y trocaron a sus integrantes en sujetos activos demandantes de prestaciones sociales. Llanamente, se volvieron simples mediadores clientelares de las obras municipales en los barrios periféricos. La instancia de agregación de intereses de origen barrial pasó a ser transitoriamente municipal, poco después se disolvió en el individualismo ciudadano, o se disgregó en el microcosmos de minúsculas colectividades autorreferidas que reclaman el "derecho a la ciudad".

Aunque no es este el lugar para evaluar la experiencia participativa del municipio quiteño, cabe señalar que su diseño institucional no incentivó la participación ciudadana ni promovió la incidencia social en la inversión municipal, como lo demostró el estudio de Hidalgo (2018) antes citado. Contrariamente, la experiencia de participación social del distrito metropolitano había puesto en tensión la titularidad individual de los derechos ciudadanos, y la organización social necesaria para su exigibilidad y cumplimiento se encontraba efectivamente debilitada, 
diríase casi inexistente, y no se hizo nada por su recuperación ni por fomentar nuevas organizaciones sociales. Ineludiblemente, la tensión se zanjó a favor de la ciudadanía individual, imperante sobre los resabios organizativos y la resquebrajada participación social.

La ciudadanía, como ejercicio individual de derechos, había desplazado a la cohesión poblacional levantada por las federaciones barriales y sus aliados políticos. El dispositivo de participación municipal contribuyó a ese propósito, diseminando por todos los contornos del distrito metropolitano una aséptica visión de ciudadanía despolitizada, enfocada en legitimar la gestión por resultados del gobierno municipal. En adelante, el discurso del individualismo ciudadano primó entre los comités promejoras, exhibiendo el simbolismo de la propiedad privada y el consumo individual como las condiciones del bienestar, cuestión que se irradió en los barrios periféricos y populares como el elemento que confiere identidad en la ciudad.

Así, la tendencia de desarticulación del movimiento barrial capitalino, en medio del aparecimiento de nuevos barrios periféricos y del crecimiento de organizaciones sociales urbanas, continuó hasta entrada la segunda década de los años 2000. En el DMQ, en 2011, según el diagnóstico del Plan de Desarrollo Metropolitano 2011-2022, se registró un total de 6233 organizaciones sociales, con 44 formas distintas de constitución, lo que ratifica la tendencia hacia la fragmentación organizativa y que estaban registradas en veinte carteras de Estado, que denota también una declarada amplitud de actividades y propósitos de las organizaciones sociales. ${ }^{7}$

7 En Quito la información disponible sobre las organizaciones urbanas, en particular de las barriales, es imprecisa debido a la persistente tendencia de subregistro y a las limitaciones metodológicas de los registros estatales. Se creó el Registro Único de Organizaciones de la Sociedad Civil para centralizar la información; en su implementación se confundieron las fuentes de registro y se hizo una captura de datos complementaria con entrevistas abiertas, sin guía estructurada de preguntas, que obtuvo información imprecisa sobre propósitos, actividades y membresías. Más allá de la validez de este instrumento, la información de las organizaciones sociales continúa agrupándose en los registros sectoriales, en este caso la referida a los comités promejoras se encuentran en el MIDUVI. 
En términos porcentuales se encontró que el $30 \%$ de las organizaciones eran fundaciones privadas, el $20 \%$ asociaciones varias, el $16 \%$ cooperativas relacionadas con el auge de las cooperativas de ahorro y crédito, y el $10 \%$ comités barriales, con lo que a esa fecha estarían registrados más de seiscientos comités promejoras de los barrios periféricos. Según el plan, las observaciones en terreno y entrevistas a dirigentes mostraron que en el territorio el $72 \%$ de las organizaciones son comités promejoras, el $10 \%$ son asociaciones, el $3 \%$ cooperativas de vivienda y el $15 \%$ otro tipo de organizaciones (MDMQ 2012, 94-5).

Del mismo modo, se confirmó la tendencia general de declive de las capacidades organizativas en las organizaciones barriales. Al comparar las cualidades organizativas en el momento del registro con su situación un año después, se encontró que la organizaciones barriales mantienen mínimos mecanismos de participación ciudadana, tienen una cierta disponibilidad de recursos, han avanzado en la atención de las autoridades municipales, pero han disminuido en la participación activa de los miembros y en la información sobre las formas organizativas (95). Distintos líderes entrevistados coinciden en el período de desgaste de las organizaciones barriales, como el dirigente fundador de la Cooperativa de Vivienda Alianza Solidaria, quien señaló lo siguiente:

Estamos en un momento de reflujo, de retroceso, frente a lo que fue en las décadas pasadas, donde se notaba una efervescencia social. Eso tiene repercusiones, por ejemplo: ¿Podemos preguntarnos a cuántas organizaciones pertenece un ciudadano común? No pasan de dos, entonces estamos en un declive. La gente ya no se reúne, nuestra práctica era reunirnos por la noche o en la madrugada, hoy la gente está enchufada a las redes virtuales y el impacto es que construimos un tipo de sociedad que ha perdido el sentido de humanidad (Melo 2014).

La desarticulación del movimiento barrial capitalino está enlazada con la dispersión organizativa y la preeminencia masiva de los comités promejoras, asumidos como la forma predominante de organización barrial y consistente con la fragmentación de los intereses y las demandas por el hábitat popular de los barrios periféricos. La pérdida de espacios federativos que agreguen los intereses barriales es el correla- 
to de la desperdigada proliferación de comités promejoras en el distrito metropolitano. En una tendencia de continuidad temporal los comités promejoras que fueron inducidos por los alcaldes liberales en los albores de la modernidad capitalina, seis décadas más tarde, luego de la ola de despegue, auge y decline del movimiento barrial, se convirtieron en la horma organizativa de los barrios periféricos que entraña el pragmatismo de sus habitantes por la inclusión urbana. Son el principal canal de conexión territorial de los barrios periféricos con las autoridades metropolitanas y los poderes de la ciudad.

Entrada la segunda década de los años 2000, es vasto el manto organizativo de los barrios periféricos. En la provincia de Pichincha están registradas 1831 organizaciones barriales, 1611 (88\%) corresponden al DMQ, y 220 (12\%) están registradas en los demás cantones de la provincia (MIDUVI 2015). Vistas de cerca, se observa que el $98 \%$ de las organizaciones barriales capitalinas están registradas como comités promejoras, el $2 \%$ restante se registran como una variedad de comités barriales, comités de desarrollo comunitario, comités de propietarios, asociaciones de ayuda social y asociaciones de moradores (2015).

De las 1611 organizaciones barriales del DMQ, el 64,8 \% o 1044 comités promejoras corresponden a los barrios periféricos del área urbana y el $35 \%$ o 567 comités a los barrios periféricos de las parroquias rurales (2015); hay que considerar la relatividad de esta última cifra ya que muchos de esos comités están en las franjas de ensanchamiento de la ciudad, en la interfase urbano/rural. Los comités promejoras no solo están desperdigados en la geografía de la ciudad, sino también al interior de los barrios periféricos.

Los barrios, las ciudadelas y las lotizaciones, aunque atravesaron por diferentes experiencias de conformación y en su mayoría comparten un origen irregular, nominalmente se reconocen en un mismo plano territorial como similares, con lo que hay comités promejoras de barrios, lotizaciones y ciudadelas. En su interior se registran delimitaciones territoriales menores por sectores, etapas, manzanas y supermanzanas, en las que se formaron los respectivos comités promejoras. Del mismo modo, dentro de las etapas, sectores, manzanas y supermanzanas, se re- 
producen microdelimitaciones territoriales entre calles, pasajes, parques y comités sociales en los que también se conformaron sus propios comités promejoras.

En términos genéricos podríamos decir que los comités promejoras en la capital metropolitana conviven en tres planos demarcados territorialmente: los de mayor demarcación corresponden a los barrios y sus similares, los de mediana demarcación a los sectores y sus análogos, y los de mínima demarcación a las calles y sus símiles. Las demarcaciones no son agregaciones de las demandas barriales; al contrario, son fracciones espaciales de los barrios con microidentidades que revelan la atomización del espacio público en los barrios periféricos y, en cierto sentido, corresponden, en el plano organizativo, al individualismo de la propiedad privada.

Son lo contrario, por ejemplo, de la experiencia del movimiento indígena ecuatoriano que, apoyado por aliados públicos y privados, supo agregar intereses en una sofisticada articulación de pueblos, identidades y organizaciones alineadas piramidalmente en comunidades agrupadas en federaciones, a su vez integradas en confederaciones adscritas a organizaciones regionales y convergentes en el movimiento nacional, que le permitió deslazarse entre la esfera política y la acción colectiva.

Las demarcaciones territoriales de los comités promejoras, en cambio, muestran orfandad de aliados políticos y de agentes inductores, no suman organizaciones ni integran niveles asociativos, no se hicieron para agregar demandas o intereses colectivos; por el contrario, dividen las demandas barriales entre requerimientos esparcidos en la geografía de los localismos periféricos. Se trata de una tendencia al faccionalismo barrial que segrega los intereses colectivos en parcelas territoriales autorreferidas y desconectadas entre sí, acentuando la desconexión organizativa y el personalismo de las dirigencias barriales.

El faccionalismo barrial intrincado con las múltiples formas ideológicas, culturales y sociales del clientelismo forma parte de la cultura política del individualismo imperante en la ciudad, por el que las singulares demandas de los comités promejoras se convierten en lo que Unda denomina "el horizonte de totalidad", esto es las demandas de unos pocos convertidas en las demandas de todos, cada demarcación territorial 
levanta sus propios reclamos como si fuesen los intereses de los demás, "sus requerimientos son formulados como los únicos legítimos que justifican la existencia de la organización” (2014, entrevista personal).

Los comités promejoras se ven a sí mismos como el gobierno del lugar, en calidad de tales sus dirigencias replican entre la población jerárquicos comportamientos autoritarios, operan como correas de transmisión de los discursos municipales; imitan los símbolos del poder local y exhiben reales o ficticias cercanías con alguna autoridad, cacique, notable, personaje o político de la ciudad. Los valores y prácticas vecinales de linaje colonial, aparentemente superados en el período de auge de las luchas poblacionales, parecen renovarse con el reflujo del movimiento barrial y el rebrote de los comités promejoras.

Es que el faccionalismo barrial otorga un margen de albedrío a los comités promejoras frente a las redes del clientelismo político. Es lo que algunos dirigentes denominan el "clientelismo consciente" (Alvarado 2014), esto es la utilización interesada desde la comunidad de los afanes partidarios por alinear transitoriamente a los barrios con una tienda política determinada, lo que es aprovechado por las dirigencias y comités para la gestión de las obras, para conseguir algún servicio e infraestructura que mejore las condiciones de vida en los barrios periféricos. Los comités promejoras capitalinos han desarrollado la camaleónica cualidad de trasladarse de una red clientelar a otra sin ningún problema, lo que es de alguna manera permisible en la búsqueda de prosperidad desde la segregación y la exclusión urbanas.

El otrora activo movimiento barrial capitalino se encuentra en un período de reflujo, varado en medio de múltiples y fragmentadas aspiraciones de la gente y los barrios periféricos. Sin perspectiva estratégica frente al avance modernizador de la ciudad, atravesado por la diversidad de prácticas, liliputienses panoramas inmediatistas y con una vastedad de comités promejoras, cuyo único propósito es la satisfacción de puntuales necesidades materiales, el movimiento barrial quiteño tal como lo conocimos parece haberse agotado.

No obstante que las organizaciones de los barrios periféricos continúan conectadas al clientelismo político, se muestran distantes, ajenas 
a los circuitos del poder y la economía regional que son los vectores por los que realmente discurre la modernidad metropolitana quiteña. Los comités promejoras de los barrios periféricos en su afán pragmático de inclusión urbana buscan en el mejor de los casos igualar lo concurrente y no disputar lo existente.

Si en el pináculo del movimiento barrial los nuevos pobladores de los barrios periféricos se resistieron a apoderarse del indeterminado estatus de ciudadanos, porque los despojaba de las identidades culturales que traían de los lugares de origen, en el ocaso del movimiento barrial, paradójicamente, los mismos pobladores acabaron asumiéndose como ciudadanos insertos en el entramado de valores, mentalidades y prácticas urbanas, exhibiendo, ante propios y extraños, los vínculos reales o imaginarios con que se identifican como habitantes de la ciudad. Ocurrió que habían asumido la ciudadanía y con ella el sometimiento al orden jerárquico del progreso de la ciudad.

En suma, en el movimiento barrial quiteño, predominaron las organizaciones sociales forjadas en la moderna racionalidad medios-fines, primando el pragmatismo dirigencial en la conformación de los barrios periféricos y la autogeneración del hábitat popular. Los comités promejoras y las federaciones nacieron y existieron condicionadas por la levedad cultural y la relatividad espacial de los barrios periféricos en la ciudad, inicialmente promovidos por las autoridades municipales en el tránsito a la urbe moderna, tejieron las redes clientelares que moldearán las maquinarias electorales locales.

Envuelto en la ideología vecinal, emergió el movimiento barrial quiteño inscrito en la estructura del poder local, con lo que en vez de canalizar las demandas barriales reproducía a su interior las jerarquías de la ciudad. El aparecimiento de nuevas organizaciones barriales al sur de la capital, con la expansión metropolitana y la irrupción de inéditas movilizaciones populares en las calles y plazas de la ciudad, removieron a la ideología vecinal como referente de la lucha barrial en los años 70 .

El apogeo de las luchas barriales sobrevino en las décadas 80 y 90 con el incremento de nuevos barrios periféricos y el reconocimiento de la diversidad poblacional que se gestaba en todos los costados de la urbe, 
estimulando la formación de las federaciones barriales que colocaron las demandas de hábitat popular en los espacios públicos quiteños. La consecución de las obras barriales y la retirada de los aliados populares debilitó a las federaciones barriales que se desmovilizaron en la segunda mitad de los años 90.

El declive del movimiento barrial acaeció en las primeras décadas de los años 2000, con el repliegue de las movilizaciones poblacionales y la extinción de las federaciones barriales, las que fueron sustituidas por los cabildos territoriales y temáticos impulsados por el sistema de participación municipal, activado en torno a los derechos ciudadanos. No obstante, los barrios periféricos siguieron creciendo y los comités promejoras multiplicándose, quedando por fuera de las federaciones barriales una vastedad de expresiones de acción colectiva urbana —las que analizaré en el siguiente capítulo-. 



\section{Capítulo IV}

\section{SUBALTERIDADES Y TRIUNFALISMOS METROPOLITANOS}

En la ciudad de Quito la emulación cultural permeó la acción colectiva, sea directamente como asimilación individual de las jerarquías de la sociedad, sea mediada como inserción diferenciada en la urbe manteniendo las identidades étnicas, o crudamente mediante las exhibiciones simbólicas del éxito neoliberal criollo. La emulación cultural de los valores prescriptivos que moldean las aspiraciones de vida urbana atravesó al movimiento barrial, cuyo propósito fue la reproducción del estilo de vida quiteño en los barrios periféricos, pero encontró visos de resistencia desde la subalteridad de los otros, de quienes quedaron por fuera del movimiento barrial — comunas ancestrales, indígenas migrantes, pueblo afroquiteño- L La emulación cultural se expresó vigorosamente en los triunfalismos de las clases medias en defensa de la capitalidad.

Del mismo modo que sucedió con la comprensión del movimiento barrial, el análisis de la acción colectiva desde la subalteridad urbana también nos desplaza a las microescalas espaciales de sus lugares de enunciación, a la geografía urbana de las disputas de identidad; si bien sus repercusiones pueden lograr alcance meso en el distrito metropolitano, sus acciones se materializaron en los lugares de existencia social de las comunas y barrios, en las calles, plazas y parques, en los no lugares de apropiación simbólica del otro (Levinas 2006), en los que ocurren los performances de resistencia cultural.

En el cuarto capítulo se analizan diferentes ángulos de la contestación social en el proceso metropolitano, la protagonizada por los grupos subalternos, que tampoco pueden considerarse como reacciones al proyecto metropolitano, fueron y son tensiones ante el pretendido universalismo del mestizaje quiteño, reactivado durante las olas de migración y la presencia del otro con la expansión de la ciudad; y al final 
se interpreta el simbolismo segregativo exhibido en las movilizaciones de las clases medias y acomodadas durante los episodios teatrales de defenestración presidencial en Quito.

El capítulo está dividido en dos secciones. En la primera me refiero a los sujetos y la subalteridad en la ciudad, empezando con una breve explicación del mestizaje y el cosmopolitismo ante la presencia del otro, a manera de introducción que contextualiza las fricciones étnicas y las tensiones identitarias en la ciudad; me detengo en los pueblos indígenas en la ciudad y en el pueblo afrodescendiente como ilustrativos de las resistencias urbanas desde la diferencia cultural, que de cierto modo forma parte de lo que Eduardo Kingman (2008) denominó la "urbanización de la vida popular". En la segunda sección reseño el período de movilizaciones de las clases medias y acomodadas que concurrieron a los derrocamientos presidenciales en defensa simbólica de la capitalidad vulnerada por las amenazas externas, en las que se ratificaron los valores prescriptivos del orden metropolitano.

\section{Mestizajes urbanos y diferencia cultural}

Las luchas de las organizaciones barriales, de los colectivos urbanos desde la alteridad, al igual que las movilizaciones multitudinarias por la capitalidad, ilustran que en el DMQ sus habitantes configuraron encrucijadas culturales en las que se solaparon la acción colectiva de las movilizaciones barriales, de las comunas en resistencia, de las fragmentaciones identitarias en ascenso y de la defensa del orden y la jerarquía en la ciudad. Revelaron cómo en la geografía metropolitana los grupos subalternos, por medio de la acción colectiva, se relacionaron en momentos de tensión social entre sí y con la ciudad.

En el capítulo anterior argumenté que el movimiento barrial quiteño, aunque quiso, no pudo abarcar el amplio calidoscopio de las organizaciones y luchas populares urbanas, pues las organizaciones populares en la ciudad no se limitan al fragmentado movimiento barrial, también hay organizaciones y luchas sociales de otros colectivos y grupos urbanos con conflictivas ocupaciones territoriales y en disputas simbólicas de los espacios públicos. Entre estas se encuentran las pro- 
tagonizadas por los pueblos indígenas, la población afrodescendiente, las organizaciones de mujeres y las juventudes urbanas, quienes junto con el movimiento barrial son expresiones de la pluriversalidad popular urbana que refiere a las luchas subalternas situadas, las luchas por el lugar, aquellas que acontecen en territorios concretos en los que coexisten plurales maneras de saber, hacer, sentir y ser en la ciudad.

Utilizo el término pluri-versal en el sentido que propone Ramón Grosfoguel (2015), esto es la necesidad de un lenguaje crítico decolonial que permita superar la tendencia a diluir lo particular en un mismo proyecto único "impuesto por la persuasión o la fuerza”, para transitar hacia un pluriverso de sentido descolonial antisistémico, respetando las múltiples particularidades y la diversalidad de las luchas antisistémicas. Se trata, según Grosfoguel (2008), de un "proyecto de liberación" constituido desde la diversidad de proyectos históricos, epistémicos, éticos, hacia un mundo pluriversal donde el poder esté abierto a la "diversalidad de formas institucionales de socialización del poder”, según las distintas respuestas ético/epistémicas descoloniales de los diferentes grupos subalternos en el sistema-mundo (215).

Las disputas identitarias de los colectivos subalternos en la ciudad son pertinentes pero no suficientes, pueden ser la base para la crítica del orden regulatorio en la ciudad, pero no alcanzan la "alteridad epistémica" que propone Grosfoguel, no son suficientes para transformar el sistema y el patrón de poder colonial gestado en la modernidad urbana. Preservar las identidades subalternas no es tan subversivo como parece, pero en la medida en que establezcan alianzas más amplias con todas las luchas identitarias, feministas, clasistas y de los diferentes grupos oprimidos en torno a la radicalización de las nociones de libertad e igualdad social, abrirían la puerta a las luchas antisistémicas dentro del sistema y no contra el sistema (2008), explica el autor.

Para situar las potenciales expresiones del pluriverso popular urbano hay que desmontar el manto cultural que encubre las disputas por la diferencia cultural en la ciudad, esto es el mestizaje urbano de apariencia cosmopolita, enraizado en la expansión metropolitana. El mestizaje es un tema vasto, complejo, con múltiples aristas que van, dice Her- 
nán Ibarra (1998), desde la exégesis estatal como núcleo de la identidad nacional, los contenidos culturales en los textos escolares, las adscripciones de los grupos sociales, las críticas de los movimientos indígena y afrodescendiente, las resistencias de las identidades juveniles, hasta los esfuerzos genealogistas por encontrar raíces del blanqueamiento en las familias de clase media (1998). Un tema que por su extensión no cabe tratarlo en estas páginas, me limitaré a realizar algunas precisiones sobre la retórica quiteña de los mestizajes capitalinos que confronta, cotidianamente, los impulsos del orden en el proceso metropolitano.

En Quito, con el distrito metropolitano consolidado durante las dos últimas décadas del cambio de siglo, terminó de desaparecer la vieja ciudad señorial y se vigorizaron las nuevas realidades urbanas mestizas: las segregaciones espaciales inducidas por el mercado inmobiliario y las fuerzas económicas; los discriminatorios estatus sociales gestados con el desigual acceso a la riqueza, bienes y servicios; los estigmas de la diferencia cultural de las poblaciones; la inferioridad de las ocupaciones humildes y la pobreza; y las disputas de identidades territoriales. Las nuevas realidades urbanas quiteñas marcaron fronteras al interior de los barrios y comunas, al igual que fronteras externas en los fragmentados espacios públicos capitalinos, donde se emiten señales del pluriverso popular urbano.

Las fronteras, a manera de líneas imaginarias, son constructos significantes transitorios y móviles que, al mismo tiempo que separan los espacios urbanos y distinguen unas realidades de otras, permiten atravesarlas, cruzar entre lugares, salir de uno y entrar en otro, encasillando a sus habitantes en estereotipos de identidad urbana. Los referentes semánticos de las fronteras espaciales en Quito cubiertas por el manto de los mestizajes urbanos condicionan la vida cotidiana de los colectivos, grupos e individuos, suelen estar delineadas por barrios y calles en las que se replican comportamientos idiosincráticos de recelo y desconfianza (Aguirre 2005, 50). Las fronteras espaciales no solo traslucen el resquemor de los sectores populares, sino el estigma mestizo de su condición de opresión, atribuyen relevancia a sus esfuerzos de inserción urbana según su adscripción a los lugares estigmatizados, como lo expresa Javier Alvarado: 
Desde los barrios, en el proceso de búsqueda de inclusión se va generando un fuerte proceso de identidad territorial, y dependiendo del tipo de lucha que haya tenido, hace que el barrio tenga una imagen buena o mala, es como un sobrenombre que tendríamos por vivir en los barrios, en cualquier parte de la ciudad. O sea, si decimos que vivimos en uno u otro lugar, solo el hecho de que pronuncies el nombre de esos lugares hace que se tenga un perfil, un imaginario de esa persona; eso hace que se tenga una identidad endosada que a veces se vuelve muy crítica. (2014, entrevista personal)

La "identidad endosada", a la que se refiere el testimonio, alude a los estigmas mestizos de la segregación urbana de Quito, que van más allá de la dicotomía congénita entre el norte de las clases medias y altas, y el sur de los sectores populares, pues en ambos lugares hay, cada vez más, numerosos contingentes de población popular y grupos ascendentes. Los nuevos barrios residenciales exclusivos se levantaron arrinconando a las comunas, convertidas en colindantes barrios periféricos; las zonas residenciales están sitiadas por las extensas barriadas populares y los asentamientos periféricos irregulares; y en varias de las parroquias rurales del distrito metropolitano coexisten zonas residenciales exclusivas, ciudadelas y urbanizaciones de clase media y barrios populares asentados en los entornos de los viejos poblados rurales.

Con la expansión metropolitana, la segregación urbana capitalina y los estigmas mestizos de diferenciación cultural devinieron sistémicos, se reproducen por todos los costados y lugares de la ciudad, acentuando las tensiones espaciales y culturales. El distanciamiento subjetivo de lo distinto y lo inferior marca el estatus de lo aceptable, las identidades endosadas a los barrios populares se aceptan, se eliminan o se transforman. Muestra de ello es uno de los barrios populares del nororiente de la ciudad, que a finales de los años 90 cambió de denominación para desprenderse de un estigma de identidad urbana derivada de sus orígenes:

El Comité del Pueblo No 2 ahora se llama Colinas del Norte, ellos hicieron un proceso de cambio de identidad porque cambiaron de nombre, hicieron un entierro del nombre paseando un ataúd por todo el barrio, porque era un barrio catalogado como muy violento. Entonces empezaron un proceso doloroso de cambio de identidad, cambiaron de nombre 
para tener más posibilidades de desarrollo. Este es un caso excepcional de cambio de nombre por una identidad negativa que estaba asociada a la violencia. (2014, Entrevista personal)

En los barrios periféricos la identidad, en un primer momento, surge del lugar y de las acciones compartidas, de las luchas que emprendieron sus habitantes durante la conformación de los barrios. Más tarde, mudan las identidades pues las experiencias colectivas son encasilladas como positivas o negativas, forman parte de las fronteras simbólicas de las hibridaciones urbanas. Aunque en cada lugar la gente construye sus referencias espaciales, los barrios periféricos apenas logran contener identidades compartidas, las hibridaciones no son suficientes para configurar una pertenencia cohesionadora de lugar, no alcanzan a moldear identidades singulares en la ciudad. Tal vez las identidades urbanas populares también fluyen por los entramados culturales de la ciudad y no solo en el lugar.

Como se ha señalado en capítulos anteriores, el proceso metropolitano quiteño conlleva nuevas realidades urbanas. El "hipercentro" extendido en la ciudad compacta, las ciudades dormitorio que someten a las comunas indígenas circundantes, las exclusivas ciudadelas amuralladas, las expandidas áreas comerciales y financieras, los vaciamientos poblacionales y semánticos del Centro Histórico, las inmigraciones rurales y los éxodos internacionales con reductos étnicos, el crecimiento de los barrios no regularizados donde con enormes esfuerzos sus habitantes se dotan de hábitats dignos, aunque en los conventillos, tugurios y quebradas - literalmente en los bordes de la vida - todavía se aloja la extrema pobreza. Las nuevas realidades urbanas son la base material del mestizaje citadino, en ellas se incuba el remozamiento de las viejas prácticas discriminatorias y racistas urbanas.

Figurativamente, son las distintas ciudades en una misma ciudad, en las que se develan las disputas por los sentidos territoriales de la reproducción social por parte de los colectivos subalternizados por los mestizajes del orden y la segregación como propias de la expansión metropolitana. Como lo señala Tella (2015), la ciudad transmite sentidos y enunciados legitimados socialmente, "nos habla” para expresar "poder, orden y diferenciación", mediante los varios elementos y funciones de 
los discursos del orden implementados por el Estado y el municipio en el territorio, los espacios y las actividades urbanas; del poder dado por las relaciones de fuerza constitutivas de la ciudad, y de la diferenciación social traspasada por la condición heterogénea de lo urbano (11).

Las ideologías, narrativas y simbolismos de las nuevas realidades urbanas metropolitanas configuran su carácter heterogéneo, misceláneo, el que suele asumirse, ambiguamente, como mestizaje cosmopolita o hibridación cultural propia de la ciudad a manera de dispositivo integrador de sus habitantes. Si bien el mestizaje como narrativa y realidad está presente desde el origen colonial de la ciudad, contemporáneamente se despliega entrelazado en los discursos del orden metropolitano que, al tiempo que unifican a la mayoría de sus habitantes, segregan a las pueblos y colectivos urbanos de origen ancestral y a los grupos de población empobrecida y humilde. Los mestizajes cosmopolitas metropolitanos se solapan con las prácticas elitistas de exhibición simbólica del poder; instituyen un orden social con referencia a valores, intereses, tradiciones e imaginarios racializados como "blanco-mestizos".

A finales de los años 60, a puertas de la expansión metropolitana, Agustín Cueva refiriéndose al mestizaje decía que "la Colonia, leyenda y realidad, sigue en pie. Solo que a fuerza de cohabitar con ella, su rostro se nos ha vuelto tan familiar que hasta parece contemporáneo nuestro" $(1976,5)$. Tras interpretar las expresiones culturales del "mestizaje étnico" estratificado entre grupos rurales empobrecidos, mestizos pobres de la gran ciudad y las variadas "clases populares arraigadas en la ciudad", todas desconocedoras del "alma indígena", Cueva ilustró el mito del mestizaje mediante los cambios urbanísticos del barrio Mariscal Sucre, el que resume la historia de las clases sociales quiteñas.

Los estilos arquitectónicos de sus grandes mansiones, dice Cueva, muestran lo que los aristócratas y burgueses querían ser: "españoles desterrados a pesar de la independencia política"; por su parte, la mediana burguesía de "subjetividad vacilante, vacía”, atraída por el primer estilo que le ofreciesen, levantó los barrios del lugar; mientras la clase media inauténtica, “aspirante a propietaria”, se allanó a las viviendas construidas por la Caja del Seguro y subsiste en el "sector la casucha de algún po- 
bre desahuciado". A medida que progresó la burguesía lo hizo también su arquitectura: los monumentos al sueño hispanista de la aristocracia criolla dieron paso a la estética de la modernidad capitalista que exhibe la aspiración "a ser en todo como los americanos del Norte" (185-90). Del mismo modo, la inautenticidad de la clase media quiteña, que hasta en "los estratos más altos carece de personalidad cultural", se expresa también en una producción cultural con un "lenguaje-ablución" que en lugar de explicar encubre la realidad. Cueva, premonitoriamente, concluyó que "la cultura mestiza es hoy una virtualidad, basada en el mestizaje étnico, y no una realidad” (207).

La inautenticidad de las culturas mestizas no es solo quiteña. La relación heterónoma entre la capital y el país hizo del proyecto mestizo regional el núcleo de la construcción de identidad nacional, proyectando la adscripción a la sociedad blanco-mestiza como el referente de la "nación en ciernes", cuyos valores y prácticas se basan en una unívoca visión de ciudadanía y no en una perspectiva plural del conjunto diverso de sus habitantes. La identidad nacional mestiza deviene esquiva, indiferente, de la histórica manera en que la diferencia cultural se fraguó en Ecuador, esto es ocultando las matrices del poder que racializaron su formación (Walsh 2009, 24).

$\mathrm{Al}$ expandir el proyecto del mestizaje criollo al de nacionalidad pretendida, como dice Catherine Walsh, no se encaró la inercia narrativa "estructural e institucional de raza o las prácticas de racialización", ni se consideró como fundacional en el proceso hacia la sociedad nacional la erradicación del racismo y la desigualdad, avanzando, alternativamente, hacia un horizonte integrador que refuerce "la diversidad, la pluralidad y la realización equitativa entre culturas” (38). El mestizaje en la ciudad capital, de apariencia mundana y centrada en la inautenticidad de la clase media, no se asemeja en nada al deseado cosmopolitismo étnico de las grandes ciudades a las que se busca imitar, en las que la presencia de diversas culturas contribuye a su identidad internacional.

El cosmopolitismo, comentan Laplantine y Nouss (2007), confiere el sentido metropolitano, mestizo a la ciudad, por el relacionamiento entre "las energías innovadoras de las diásporas procedentes de todos los rincones del planeta", cada una con su memoria, tradiciones, len- 
guas y esperanzas que configuran el "polis-cosmos, la ciudad mundo". El cosmopolitismo moldea una misma identidad urbana, más allá de que las comunidades culturales se apropien de los espacios y conformen los guetos de la segregación y de la autarquía, el espacio cosmopolita de las grandes urbes se caracteriza por el hecho de que "las múltiples minorías asentadas unas junto a otras terminan por formar la mayoría”, no hay una cultura central dominante, sino varias descentradas, excéntricas, frente a la homogeneidad de la comunidad de ciudadanos "en equilibrio incesante y estimulante" (187-8), explican los autores.

El mestizaje cosmopolita metropolitano quiteño es lo opuesto al cosmopolitismo de las grandes ciudades, al que se refieren los autores. En vez de contribuir a una identidad urbana enriquecida desde la diversidad cultural, se empeña en una uniformidad ciudadana basada en el anteriormente señalado complejo de inferioridad colonial que desvaloriza lo propio y sublima lo ajeno. En el distrito metropolitano las culturas de raíz ancestral nativas y llegadas, así como los grupos segregados por el crecimiento urbano, difícilmente se relacionan entre sí, apenas lo hacen con minúsculos colectivos en situación de subalteridad, arrinconados en los no lugares e inferiorizados en los escalones más bajos de la sociedad blanco-mestiza. Ni siquiera a guisa de exotismo multicultural son considerados en el proceso metropolitano.

Sus memorias y saberes perviven en los bordes del mestizaje urbano, limitado, en el mejor de los casos, al manido sincretismo simbólico de las ritualidades andinas religiosas, solares y terrenas, intercaladas con expresiones de estilo new age como formas cuasi folclóricas del mercado cultural. Las identidades ancestrales desvalorizadas y los grupos relegados por el orden de la ciudad no son motivo de vanaglorias urbanas, sino de vergüenza, de ocultamiento de las disonancias, de un jerárquico distanciamiento de las colectividades y personas de raíz ancestral. El mestizaje metropolitano, centrado en la inautenticidad de la clase media, hace ostentación de un "blanqueamiento" gestado apenas décadas atrás, sin memoria propia considera que la identidad quiteña está en proporción a las generaciones oriundas de la ciudad, en una suerte de impostada "limpieza de sangre" que sedimenta el linaje indio. 
Aferrado al simbolismo del consumo y del mercado, aunque limitado económicamente en sus aspiraciones, el mestizaje de clase media alardea de su familiaridad con la memoria histórica de la señorial clase acomodada, refrendada en la iconografía cívica de los próceres locales, mientras ignora y repudia las memorias de la diáspora afro y de los éxodos de los pueblos indígenas. Se abochorna de la diferencia cultural y la inferioridad social, pese a que en las ciudades extranjeras que tanto admira la diversidad cultural se asume como potencialidad multicultural.

El mestizaje es la pieza central en un relato creado en términos sociales y políticos, con el que también se configuró el DMQ. Sus narrativas y prácticas racistas operan, diacrónicamente, como dispositivos culturales de integración-separación de la población, mediante los cuales se impusieron los principios universalistas del progreso y la ciudadanía volcados principalmente en el individualismo, el ascenso social y el blanqueamiento. Erigieron un imaginario colectivo de identidad urbana nacido del complejo de inferioridad, por el cual lo que ocurre o no en las ciudades occidentales es la referencia del adelanto en la capital del país.

La experiencia de racialización e inferioridad de lo ancestral y lo humilde está enraizada en la sociedad local desde la Colonia, como un proceso de "mezcla de razas" y de creación de castas racialmente mestizas, distantes de los blancos, indios y negros (Ibarra 1998, 9). Contemporáneamente, se readecuó a los cambios modernizantes que experimentó la ciudad en la primera mitad del siglo XX y continuó hasta el presente como una suerte de "sentido común" que acompaña a la expansión metropolitana. La sociedad señorial de antaño se convirtió en una sociedad cuasi cosmopolita, con la presencia de nuevos sujetos como los trabajadores fabriles, comerciantes, una creciente clase media, migrantes indígenas, afros y mestizos pueblerinos. Las fricciones entre la vieja estructura social y las nuevas presencias urbanas provocaron los primeros conatos de lucha de clases y confrontaciones culturales que "diversificaron la conflictividad entre migrantes y capitalinos" en la ciudad (Bustos 1992, 180).

De acuerdo con Bustos (1992), la convivencia de tradición y modernidad entre los años 20 y 50 produjo nuevas identidades que politi- 
zaban las demandas sociales, y emergieron otras percepciones, valores, espacios y actores que atribuían sentidos disímiles de identificación y diferenciación frente a la ciudad, en un proceso relacional de configuración de lo que denominó "proyectos de identidades culturales urbanas" (182). Se formó el "pueblo" como una identidad política incluyente de las demandas de los diversos sujetos como consumidores, usuarios, desocupados, pobres y trabajadores en general; emergió una clase obrera en formación compuesta por artesanos, obreros fabriles y grupos de empleados del sector servicios. Ambas, el pueblo y la clase obrera, empezaron a ser protagonistas de los hechos políticos más relevantes del período (180-2).

Asimismo, los cambios espaciales y sociales hicieron de la ciudad de Quito una suerte de emblema, materializado en el imaginario colectivo con la retórica de "quiteñidad o quiteñismo", a manera de entramado de adscripciones y autoadscripciones identitarias prejuiciadas que, alimentadas por el crecimiento espacial y poblacional, estigmatizaban a los foráneos como lugareños ordinarios e iletrados, recurriendo a un léxico peyorativo. En un juego de contrastes taxonómicos en torno a la procedencia de la gente, se fue estableciendo el "quiteñismo" como una recurrente nostalgia de un pasado de ribetes aristocráticos, al mismo tiempo que una aspiración de progreso (182). Sin embargo, tras el "quiteñismo", se esbozaba el desprecio por lo ancestral, con lo que la conflictividad cotidiana más visible surgió entre los quiteños de nacimiento y los forasteros, dando lugar a un enfrentamiento étnico-cultural que visibilizó al racismo en la ciudad (Espinosa 2003,27). La dicotómica identidad entre propios y extraños permeaba la moderna identidad quiteña.

En las prácticas de discriminación urbana, los sectores dominantes de raíz señorial y la mediana burguesía se autoadscribieron como la "gente decente", esto es familias y personas "sin contaminación de lo indio", y asumieron la conflictividad derivada de las nuevas presencias sociales en términos de oposición étnico-cultural, como un avance del “cholerío" sobre la urbe blanco-mestiza (Bustos 1992, 183). Los afuereños provenientes del campo y de los pueblos rurales, que forman parte del proceso de migrantes a la urbe, eran percibidos por los capitalinos de clase alta con el apelativo de "chagras o cholos", que como señala 
Bustos (183-4) eran acepciones corrientes que referían a una jerarquía de valores de estatus inferior y disruptivo.

Por su lado, los mestizos de clase media y los sectores populares no indígenas de mayor raigambre urbana veían a los migrantes como directos competidores en el mercado de trabajo y rivales en los escuetos medios de ascenso social, con lo que, igualmente, replicaban las prácticas discriminatorias para distanciarse culturalmente de los migrantes, a la vez que buscaban establecer algún tipo de identificación simbólica con las clases pudientes para integrar y ser reconocidos en el estatus de la "gente decente" (186). El quiteñismo como encarnación de los mestizajes urbanos, en su afán de blanqueamiento, operaba, sincrónicamente, tanto en el plano vertical para diferenciar a los grupos dominantes de los oprimidos cuanto en el plano horizontal al interior de las clases medias y de los sectores populares, para desigualarse de lo ancestral, de la pobreza y de los humildes.

Algunas obras de la narrativa literaria escrita entre los años 20 hasta entrados los años 80, reseñadas por Hernán Ibarra (1998, 34-8), retratan las percepciones mestizas de la ciudad, "sus personajes, dramas y ocultamientos", acaecidos en los distintos episodios del paso de la sociedad señorial de antaño a la nueva sociedad moderna. A manera de retazos de recuerdos sin una "visión global de la ciudad", son añoranzas localistas de una aristocracia venida a menos, de clases medias en busca del ascenso social abandonando sus barrios de origen, o de "espesos espacios públicos municipales". Refieren a un pasado reciente, ya que los eventos posteriores carecen de huellas, los mestizajes urbanos del presente no pueden abarcar las experiencias inmediatas de las nuevas generaciones, cada vez más alejadas del pasado (38). Es una nueva configuración de la sociedad moderna carente de memoria.

La retórica de quiteñidad basada en la inferioridad de lo indígena impuesta por los hacendados durante la modernización agraria precedente no solo estigmatizó al indio como un sujeto irracional que debía civilizarse en aras del progreso, cuestión ratificada por las élites locales, sino que arraigó el racismo como el primordial dispositivo regulador de la sociedad capitalina (Espinosa 2003, 29). Dio pie para que décadas 
más tarde los migrantes fueran encasillados como inferiores y atrasados, recurriendo al léxico peyorativo y discriminador sobre el cual Manuel Espinosa realizó una arqueología de sus orígenes, modismos, usos y significados que muestran el solapamiento entre los estamentos étnicos raciales y la estratificación socioeconómica (29-49). La retórica mestiza de quiteñidad en una sobreposición de dinámicas culturales, tiempos históricos y prácticas inferiorizadoras se usó, en adelante, para enunciar el orden y la jerarquía en la moderna sociedad capitalina. Devino en un dispositivo práctico de discriminación y racismo de la diferencia cultural, usado a manera de léxico corriente enunciativo de las desigualdades como propias de la sociedad capitalina, sometiendo a los grupos sociales y a las personas en condición subalterna.

Del mismo modo que se inferiorizó a lo indio a comienzos del siglo XX, durante su segunda mitad, desde los años 60 en adelante, se expresó públicamente la discriminación a la población afrodescendiente en la ciudad, la que fue estigmatizada también como foráneos "invasores", una raza iletrada "sin destrezas ocupacionales”, y asumidos públicamente como una "amenaza” a la seguridad de la población blanco-mestiza. Los localismos ideológicos de inferioridad de la cultura afro están enraizados en las costumbres racistas decimonónicas que "animalizan a los negros", como impropios a la cultura y a los valores de la civilización, con posturas racistas de las élites intelectuales y académicas que hasta entrados los años 60 sostenían visiones del pueblo afro como "personas sin inteligencia y cultura difíciles de civilizar” (De la Torre 2002, 19-21).

Desplazados al último peldaño de la estructura social por los valores y prejuicios racistas de los mestizajes urbanos, ni siquiera la retórica contemporánea del quiteñismo contemplaba términos para la racialización de la presencia afro en la ciudad. Su cultura continuó oprimida por medio de prácticas violentas y cotidianos lenguajes de agresión y desprecio, refrendados en los valores del quiteñismo de "la gente decente". En un ambiente de hostilidad generalizado con lo afro, no es de esperar que haya señales de adscripciones de pertenencia a la ciudad, al menos en las primeras décadas de presencia del pueblo negro en la capital, lo explica el representante del movimiento afroecuatoriano Juan Carlos Ocles: 
Como tener unos símbolos referentes, no. Lo que sí se marcaba es la cuestión de los que eran de la ciudad, que se sentían los "quiteños" y los invasores. Los invasores venían a ser los afrodescendientes, en el caso nuestro, y tal es así que había frases de que somos una raza proclive a la delincuencia, que se está tomando los suburbios y barrios populares. Al decir eso significa que no somos de aquí, cosa que los medios de difusión comenzaron a difundir de tal manera que el imaginario social veía a la población afrodescendiente primero como invasores, segundo como delincuentes y tercero como los más atroces. De todo lo que pasaba eran culpados los negros, todo negro que andaba en grupo era llevado a la cárcel. Era terrible porque la prensa vendió la idea de que los negros eran matones, los negros eran asesinos, por lo tanto había que destruirlos. (2014, entrevista personal)

Los estigmas de inferioridad y las crueles imágenes montadas en la opinión pública a las que se refiere el testimonio evidencian el ambiente de hostilidad imperante en la expansión metropolitana ante las primeras presencias afro. No es fácil imaginar que germine rápidamente la identidad afro en el contexto de violencia y rechazo de una ciudad que no los acogió, pues como "pueblo afro no nos sentíamos parte de Quito", señala Ocles. El desprecio mestizo se ejerció sobre los negros, arrinconándoles en los tugurios de las laderas del Pichincha, localizadas al costado noroeste de la ciudad, en unos conventillos improvisados, arrendados en condiciones infrahumanas de hacinamiento, con servicios precarios y hostigados por sus propietarios ante cualquier expresión cultural comunitaria. Las primeras presencias afro en la capital fueron en los no lugares, rechazadas por la ciudad y despreciadas, incluso, adentro de la propia marginalidad urbana.

Obligados a vivir en la ciudad por la pobreza en el campo, el pueblo afro desarrolló su propia estrategia de sobrevivencia: residir y trabajar en la ciudad para obtener ingresos y regresar periódicamente a sus lugares de origen para cargarse de la energía cultural que les permita continuar en la agreste ciudad. Comenta Ocles:

Bajo esta situación el pueblo afro no se sentía parte de la ciudad, y un elemento claro de no sentirse parte de la ciudad era que trabajaba, iba reuniendo dinero y en los eventos grandes como la Semana Santa ba- 
jaban a su tierra para llenarse de fuerzas, a llenarse de energías y luego retornaban. (Entrevista personal)

La identidad urbana del pueblo afro se fue configurando entre la inserción material en la ciudad y el retorno espiritual al lugar de origen, aunque el regreso a los ancestros cada vez va quedando en la memoria colectiva, en los "guardianes de la memoria", diría Juan García, pues la tendencia del pueblo afro es convertirse en población urbana. Las primeras presencias afro en la ciudad fueron progresivamente cambiando en la medida en que aumentó su migración, con la consolidación de los asentamientos afro en determinados barrios periféricos y con la creación de las organizaciones de afrodescendientes en defensa de su cultura y el ejercicio de los derechos colectivos — como más adelante se explica-.

Las inserciones viviendísticas, ocupacionales y económicas de los grupos secularmente excluidos se dan en los estratos segmentados de la economía, por lo regular informales, y en el sector terciario, ocupados por la población indígena, afro y pobre, algunos de los cuales han experimentado crecimientos relevantes en una suerte de emprendimientos étnicos y populares exitosos, en los que se reproducen las afirmaciones de estatus, paradójicamente, buscando restablecer los vínculos primarios imaginarios o reales de sus orígenes familiares, provinciales, comunitarios y comarcanos. Las identidades populares mestizas también se configuran en la tensión entre las inserciones materiales en la ciudad y las añoranzas del lugar de origen, entre las memorias de los desarraigos y las condiciones urbanas de recepción, al menos en las primeras generaciones de migrantes.

Una experiencia novedosa que se distanció de los estigmas de la inferiorización urbana, y que se blindó de los prejuicios mestizos de la retórica de quiteñidad, fue la protagonizada por la cooperativa de vivienda Alianza Solidaria en la zona de Quitumbe, que ha construido siete grandes conjuntos vecinales, autogestionando comunitariamente los servicios educativos, equipamientos, comercio y salud, presentándose a sí misma como la síntesis de las luchas viviendísticas de los barrios periféricos del sector suroriente de la ciudad (Melo 2014). La identidad de la cooperativa recoge la memoria colectiva de los barrios obreros, 
de la cooperativa Lucha de los Pobres, de la cooperativa Villa Solidaria hasta llegar a Quitumbe, un área de invasiones y traficantes de tierras en la que se formaron numerosos barrios irregulares, donde la cooperativa emprendió un camino colectivo de integración territorial y fortalecimiento identitario (2014), pues lo que empezó como una cooperativa solidaria de vivienda, treinta años más tarde, se proyecta como un proceso de hábitat popular.

Las adscripciones de sus miembros forman parte de las identidades del sur de la ciudad. Sus dirigentes consideran que están empeñados en el tratamiento proactivo de los asuntos y problemas "propios del sur", en "resistencia al colonialismo excluyente de nuestra ciudad", y expresan la ecuatorianidad, mientras en el centro y norte expresan la quiteñidad, porque al sur casi no hay quiteños, "la mayor parte son gente venida de todos lados, menos de Quito". El dirigente de la cooperativa reseña la identidad de sus habitantes de la siguiente manera:

Hay dos ciudades. Vivir en la capital depende del lugar donde uno se ubique. Vivir en la ciudad hecha para el turismo, hecha para los ricos, para los que tienen posibilidades, o vivir en la ciudad del sur, donde no tienen nada que ver los relatos y narraciones que hacen los quiteños de cepa, para ellos no está presente el sur de Quito. Frente a esto nosotros tenemos otra visión, la gente de aquí tiene sus propias idiosincrasias, sus propias tradiciones y las festividades son otra cosa, la gente se organiza en cada barrio, en cada cuadra y las festividades son algo circular, aunque sin duda estamos también afectados por el consumismo y la globalización. Tenemos bastante gente venida de distintas provincias, y hay muchos aportes culturales que reproducen distintas identidades. La otra es la capacidad de solidaridad, hacia la unión, hacia le interacción social, que se presenta con mucha facilidad, más que en el norte o en el centro, todo eso sigue configurando una identidad propia. (Entrevista personal)

En la experiencia de la cooperativa Solidaridad la identidad popular mestiza del sur es asumida como un cambio de las tradiciones señoriales capitalinas; no es un simple sometimiento a la modernización general de la ciudad, sino un adentrarse en una "propia modernidad", sin renunciar a los orígenes obreros, populares y afuereños, más bien "reclamando su presencia, sin ocultarlos". Lo que para otros es indigno, 
para los habitantes de Solidaridad es motivo de orgullo, por ejemplo: lo valioso de "vivir junto a las quebradas", de disfrutar de la riqueza ecológica de una geografía irregular, cuestión que fue pensada y gestionada por la gente de aquí (2014), señala el dirigente barrial.

Las mujeres en Quito han sido las mayores protagonistas de las luchas por la reproducción social, en las lides de las organizaciones viviendísticas que dieron origen a los barrios periféricos, y en los procesos de inclusión social de sus habitantes en los que se tejen las identidades populares, mestizas, indígenas y afro en la ciudad. Las contribuciones materiales y políticas, los roles de liderazgo y movilización, y las iniciativas culturales de las mujeres populares también han sido ocultadas con la retórica del quiteñismo cargado de valores patriarcales, y por el machismo ideológico subyacente en las prácticas socioorganizativas de las dirigencias barriales. No obstante, las mujeres han creado múltiples organizaciones, con diversas características y en varios sectores, que contribuyen al avance democrático de la ciudad, entre las que destaca el Colectivo Mujeres por la Vida que, mediante la toma de un parque, formaron la cooperativa San Juan Bosco del Itchimbía.

A mediados de los años 90, un grupo de mujeres provenientes de varias organizaciones del sur de Quito, como la Unión de Mujeres Tarqui y la Coordinadora Popular de Quito, formaron el colectivo Mujeres por la Vida como una agrupación de organizaciones barriales de base y de mujeres de sectores populares, comprometidas en la búsqueda de satisfacer sus necesidades de "salud, vivienda, economía popular y solidaria, derechos de participación y educación” (Hernández 2014, entrevista personal). La iniciativa organizativa creció y se extendió como parte del movimiento nacional de mujeres, participando en las marchas, mítines y eventos políticos convocados por la entonces Coordinadora de Movimientos Sociales.

El colectivo de Mujeres por la Vida, "como un tema más propio de las mujeres”, se encaminó a conseguir vivienda popular. Dirigió y protagonizó la toma de tierras en lo que ahora es el parque Itchimbía, una colina del centro-oriente de la ciudad, y logró que numerosas mujeres jefas de hogar, de condición humilde, accedan a la vivienda. Tras varios años 
de confrontaciones con el municipio, marchas hacia el centro, plantones callejeros y encadenamientos a las viviendas en el asentamiento para evitar el desalojo, y de desmontar el estigma adosado de delincuentes o traficantes de tierras, mostraron que se trataba de mujeres jefas de hogar en busca de vivienda. Lograron levantar la propuesta Parque, Vivienda Itchimbía (2014), que combinaba un área de vivienda y servicios con el cuidado comunitario del parque.

La cooperativa condujo una exitosa negociación entre el municipio metropolitano, que regularizó la toma de tierras, la Cámara de Comercio de Quito, que les otorgó un crédito sin garantes, la empresa constructora que edificó las viviendas, y el apoyo de varias fundaciones que facilitaron pequeños créditos solidarios (2014), con lo que entre 2003 y 2004 las mujeres pasaron a ocupar sus nuevas viviendas.

Con una sólida organización comunitaria, comenta la dirigente María Hernández, las mujeres gestionamos los servicios de "comedor, centro infantil, apoyo escolar, huertos familiares y comunitarios, un centro de energías alternativas, reciclaje de basura, trabajo comunitario semanal, escuela de formación", y formamos varias comisiones para resolver los múltiples problemas de la vida cotidiana en la cooperativa. No solo se buscaba un entorno urbanístico digno, sino también una convivencia en condiciones de equidad y calidad para las mujeres, juntando a la solución de sus necesidades concretas el aprendizaje de que hay necesidades estratégicas como la equidad de género, explica Hernández:

El tema de la violencia también fue tratado. Cuando la gente se peleaba entre familia, los niños eran los que buscaban a la comisión de derechos de género, y la comisión tenía autoridad para resolver los temas, lo que es algo difícil de conseguir. Se premiaba a las familias que vivían en armonía, y los hombres que pegaban a las mujeres se les exhibían en la Asamblea, así como se les exhibe a los deudores, y tenían vergüenza. Se trabajaba muchísimo en la formación y en la concienciación. (Entrevista personal)

Las adscripciones ideológicas de las mujeres de la cooperativa San Juan Bosco del Itchimbía también son parte de las identidades del sur de la ciudad. En la lucha por la vivienda, ellas sufrieron la segregación 
urbana de la ciudad ordenada en centralidades que benefician a las clases medias y acomodadas, en perjuicio de los sectores populares. Aunque entre la población popular mestiza se reproduce el lenguaje peyorativo del quiteñismo, sus íconos costumbristas y personajes han perdido vigencia en el sur de la ciudad, "no son significativos para la gente como debió ser hace cuarenta años", anota la dirigente. "Para las nuevas generaciones no significan nada”, sus referencias vienen de las identidades traídas por los migrantes, con las que se están formando nuevas identidades que se expresan, por ejemplo, en un calendario festivo y ritual de las localidades de origen que están enraizadas en la gente y que no son tradicionales de Quito. Es la diversidad cultural del sur, señala Hernández:

Quito es una ciudad tan diversa, que ya no hay una identidad quiteña, sino diferentes identidades en la ciudad que se han ido construyendo. Unas de acuerdo con el territorio, de dónde vienen, cómo han migrado y eso va constituyendo la identidad de la gente. Hay también las otras identidades sociales, por ejemplo los jóvenes que tienen diversas identidades. No puedo encontrar una identidad superfuerte que sea común para todos, tal vez las religiosas. (Entrevista personal)

En efecto, las identidades juveniles urbanas, a las que alude la representante de la organización de mujeres, son diversas. Más aún, dado el predominio de la población joven en el distrito metropolitano, las múltiples identidades juveniles atraviesan la sociedad quiteña, tienden a expresarse en distintas formas de agrupación y a configurarse, territorialmente, por todos los costados de la urbe.

Aunque siempre ha habido rupturas generacionales de las juventudes en la cultura, el arte y la política, el denominado "sujeto joven", en tanto actor político organizado, emergió en el debate académico local a comienzos de los años 60, cuando aparecieron pintados los muros de algunas ciudades con la frase: "URJE, la esperanza". Eran las brigadas de la Unión Revolucionaria de Juventudes Ecuatorianas (URJE), un “típico frente de juventudes”, identificado con la Revolución cubana y formada por tres partidos disímiles que, con la consigna: "Lucha heroica por una patria nueva", convocó a miles de jóvenes, hombres y mujeres que "luciendo uniformes verde olivo" se tomaban las calles como un desafío 
y una esperanza. El "descontento y la voluntad de los jóvenes irrumpió espontáneamente por doquier, por encima de los partidos políticos de la izquierda paralítica”, explica su fundador Jaime Galarza (1990, 14). Aunque duró poco, la experiencia de URJE marcó el inicio del protagonismo político de las juventudes en el país.

En adelante, se sucedieron varias organizaciones de jóvenes disputando los espacios sociales, institucionales y políticos en la ciudad. En los años 60 se creó la Federación de Estudiantes Universitarios del Ecuador (FEUE), en los 70 la Federación de Estudiantes Secundarios (FESE), y varios frentes estudiantiles promovidos por los movimientos de izquierda involucraron activamente a las juventudes en las diversas luchas estudiantiles, barriales y populares urbanas. Igualmente, los jóvenes militantes de izquierda, los grupos juveniles y las CEB apoyaron la expansión del movimiento poblacional capitalino en los años 80 hasta entrados los 90. Sin duda también hubo agrupaciones políticas de jóvenes junto con el movimiento indígena, especialmente en respaldo al Movimiento de Unidad Plurinacional Pachakutik. Del mismo modo que la juventud de clase media quiteña fue una de las mayores protagonistas en las multitudinarias movilizaciones que derrocaron a Bucaram y Gutiérrez.

Con variantes ideológicas y distintas expresiones organizativas, hay una línea de continuidad, no necesariamente acumulativa, en el protagonismo político de las juventudes capitalinas que va más allá de los partidos políticos, lo que no ocurre con el accionar social de las juventudes que, en cambio, se muestra discontinuo, con agrupaciones dispersas y fraccionadas expectativas. El interés académico por las identidades juveniles se derivó del aparecimiento de las pandillas en los años 80 (Andrade 1990, 36), surgidas en las zonas marginales de los barrios periféricos y suburbios; se fue extendiendo hacia sectores de clase media, siempre moviéndose circularmente en "el terreno de los desposeídos", y cuestionando los estigmas de violencia, delincuencia y drogadicción que les someten, así como las políticas de intervención que de ellas emanan.

El acercamiento a la realidad juvenil empezó a dar cuenta del calidoscopio de expresiones socioculturales juveniles en expansión. René Unda (2010), en su estudio de las identidades juveniles quiteñas, propu- 
so una tipología que distingue entre jóvenes hijos de migrantes, jóvenes en actividades religiosas, juventudes políticas, galaxia musical juvenil y jóvenes estudiantes, en cada una de las cuales existen diversas formas asociativas (33-4). Encontró la enorme complejidad de relaciones que tejen, con ramificaciones hacia nuevas formas de culturas juveniles, juventudes urbanas, juventudes rurales, grupos con distintos niveles de organización, a lo que denominó "neo-asociacionismo" juvenil, expresión de las "creatividades en acto", esto es la diversificación de sus formas identitarias que, al tiempo que muestran "mayor atomización de las agregaciones juveniles", se recrean en "nuevas formas asociativas a través de fusiones y mixturas" (144-5).

Una aproximación a las organizaciones juveniles en la ciudad mostró que para el año 2006 predominaban las organizaciones deportivas que representaban el 33,2 \%, las organizaciones religiosas el 24,1\%, los grupos artísticos el 22,0 \%, las otras organizaciones el 22,0 \%, las organizaciones políticas el $8,7 \%$, las pandillas el $5 \%$ y el gobierno estudiantil el 4,1\%, respectivamente (Rodríguez y Tingo 2013, 86). Se trata de un segmento poblacional constitutivo de la sociedad capitalina, con una vastedad de expresiones asociativas que se mueven en circuitos espaciales y culturales autorreferidos.

Entre los grupos artísticos, las otras organizaciones y las pandillas se conforman las microsociedades subterráneas, underground, del tipo "tribus urbanas" en las que se recrean las identidades juveniles. Es el caso de los jóvenes de las agrupaciones hardcore y punks que se vuelven gregarios en sus "comunidades emocionales", en las que se desahogan del individualismo al que les somete la sociedad urbana, y mediante "socialidades dispersas", priorizan sus saberes en las relaciones interpersonales expresadas en la corporeidad de sus experiencias. Son "formas de resistencia al individualismo urbano”, que varían según los casos, desarrollando referencias grupales reconocibles que "convierten a sus miembros en actores distinguibles de otras culturas juveniles” (Guerrón 2012, 167-8), valoradas en el contexto de la sociedad capitalina homogénea.

Lo propio ocurre con las identidades juveniles skinhead que, ocupando sitios simbólicos, sustituyen el anonimato social con el recono- 
cimiento dentro de las sociedades subterráneas. Las agrupaciones skinhead no se consideran fuera del sistema, aunque declaran que sí lo están, "buscan protegerlo de lo que para ellos está corrompido", con acciones que despliegan las destrezas físicas de sus miembros, las que no son siempre aceptadas en la sociedad por ser "expresiones de intolerancia desmedida” (Vaca 2013, 221-2). Es la agrupación que asume la violencia como su fortaleza, por eso es considerada la cultura juvenil más agresiva de las sociedades subterráneas y respetada por las otras agrupaciones, lo que le confiere seguridad e identidad.

Las adscripciones identitarias juveniles se dan al interior de microsociedades, por fuera de estas no hay mayores señales de búsquedas compartidas de cohesión colectiva juvenil, como lo expresa la siguiente opinión de un joven quiteño:

estamos muy divididos todos. Somos un cuerpo sin pies ni cabeza... No nos organizamos bien, o sea, cada quien organiza su realidad o desde lo que vive. Pero no, en realidad, todavía no estamos como organizados todos. Así como para hacer algo así. (Rodríguez y Tingo 2013, 111)

En medio de la atomización asociativa, hay expresiones contestatarias de las identidades juveniles quiteñas ante la segregación urbana, como el caso del colectivo Al Zurich, que supo transformar la identidad negativa del sur de la ciudad en un elemento turístico y cultural en el que se reconstruye positivamente con la valoración del patrimonio edificado de los barrios del sur, la identidad urbana discriminada. No obstante, el comportamiento generalizado de la sociedad quiteña es la inferiorización de las identidades juveniles, recurriendo a los estigmas peyorativos de una recreada retórica de la "gente decente" que discrimina las diferencias culturales, como sucede con las culturas urbanas conforme comenta una joven mujer punquera inquirida al respecto:

Yo creo que sí. Yo creo que todo lo diferente es discriminado actualmente. Las culturas que son diferentes, las preferencias sexuales, políticas: todo eso es discriminado. Es normal. Le estorba a la gente lo diferente. (113)

El comentario, en pocas palabras, ratifica la continuidad de los localismos identitarios de los mestizajes urbanos, que con propósitos 
discriminantes replican los simbolismos de la arcaica tensión entre los foráneos, los diferentes y los humildes, respecto de lo propio, el orden y lo digno de la ciudad. Los valores de una colonialidad vergonzante, velados en las identidades mestizas, persisten en las prácticas individualistas de desigualamiento de lo indio y afro, de la pobreza y de los distintos como parte del "sentido común", despreciando a las culturas comunitarias y estigmatizando a las identidades juveniles. Los modos fácticos de existencia de los mestizajes urbanos, en medio de los clivajes étnicos, generacionales, socioeconómicos y culturales, se asumen con vergüenza, debido a su cercanía con lo ancestral y la pobreza.

Muestran la dificultad para materializar la deseada identidad cosmopolita, enlazando la pluralidad cultural con la memoria mestiza de la capital. Las limitaciones no son solo de los grupos subalternos que ven encubiertas, sin reconocimiento en la historia oficial, sus contribuciones al avance de la ciudad; son también las reticencias de las propias identidades mestizas empeñadas en la pérdida de referentes compartidos, en aparentar el individualismo citadino con el ocultamiento racial, el estigma de la diferencia y la inferioridad de la pobreza.

\section{Los pueblos indígenas urbanos: Etnogénesis y resistencia}

El DMQ es el cantón con la mayor población indígena del país. De acuerdo con los datos del Censo de 2010, en el cantón Quito residen 66513 indígenas, de los cuales el 99,3 \% están asentados en el área urbana (INEC 2010), prácticamente la totalidad de la población indígena del cantón habita en la capital, con lo que es la urbe de mayor cantidad y diversidad de indígenas residentes. La segunda ciudad con población indígena es Guayaquil que tiene 31531 indígenas, seguida con una distancia considerable por Otavalo donde viven 11219 y luego Riobamba con 9 783. En Quito representan el 30,4 \% del total de la población indígena urbana ecuatoriana, con lo que casi un tercio está en la capital. En relación con la población del distrito metropolitano, la población indígena equivale al 4,11 \% de sus habitantes, pues el 82,23\% se "autoidentifica según la cultura y costumbres" como mestizos, el 7,11 \% como blancos y el 2,68 \% como afroecuatorianos (2010). 
Los indígenas urbanos, a diferencia de los indígenas de las zonas rurales, han desplegado distintas relaciones con la capital del país. Las comunas circundantes con tradiciones de propiedad comunal de la tierra, originarias del lugar e identificadas contemporáneamente como el pueblo kitu kara, han tenido vínculos permanentes y flexibles con la ciudad de Quito.

Los indígenas migrantes, en cambio, han desarrollado diversas vías generacionales de ocupación, uso e inserción en la ciudad: unos han visto en la urbe un plataforma transitoria para migrar al exterior, otros asumen una presencia intermitente en la ciudad como condición de continuidad de sus comunidades de origen, hay quienes buscan en la urbe una estrategia de sobrevivencia familiar y los demás ven en la ciudad una oportunidad de inserción y residencia definitiva abandonando su procedencia rural. En la capital hay indios nativos, migrantes transitorios y residentes, unos con experiencias de inserción exitosas, otros en condiciones precarias de subsistencia, algunos están organizados y otros no. Los indígenas en Quito revelan un espectro de situaciones económicas y culturales diversas, en las que se mantienen sus adscripciones étnicas en formas comunitarias, familiares, grupales e individuales.

Los pueblos indígenas, que habitaron originariamente el territorio en el que se asienta la ciudad de Quito, están constituidos en la actualidad por comunas, anejos, poblados y parroquias rurales que tienden a ser absorbidas por la expansión metropolitana, poniendo en riesgo de disolución a sus comunidades, algo que nunca antes había ocurrido. Hay comunidades indígenas originarias localizadas por todos los costados de la urbe: Chilibulo-Marcopamba-La Yara, Santa Clara de San Millán, Nayón, San Isidro del Inca, La Toclla, Leopoldo Chávez, Lumbisí, El Tingo, San Miguel de Calderón, Cocotog, Llano Grande, Zámbiza, Yunguilla y Rumiloma, entre otras.

Las comunas no originarias se formaron recientemente en tres momentos diferenciados. Aproximadamente un tercio de ellas se creó con la Ley de Organización y Régimen de las Comunas de 1937, otro tercio se conformó como consecuencia de la Ley de Reforma Agraria de 1964, y las restantes en las parroquias rurales se crearon con la Ley de 
Reforma Agraria de 1972. Están integradas, en general, por exhuasipungueros y trabajadores agrícolas que formaron cooperativas campesinas, comunidades, anejos, poblados y barrios cohesionados por lazos de parentesco, ritualidad y afinidad que se mantienen en calidad de comunas en Catzuquí de Moncayo, Miraflores, Guápulo, Sigsipamba, Palugo, Alambi, Alaspungo, Tanlagua, Tanda, entre otras. Hay comunas que se formaron en el siglo XIX en calidad de posesiones de hecho, como el caso de La Toclla creada en 1839, o la comuna Santa Clara de San Millán en 1911, durante el Gobierno del general Eloy Alfaro (Andrade 2013, 14-5).

En 2012, según cifras del municipio metropolitano, estaban registradas en las distintas instituciones públicas un total de 75 comunas en el territorio del distrito, de las cuales cerca de 49 se encuentran activas, de estas, tres comunas son urbanas y las restantes 46 son rurales (Instituto de la Ciudad 2013, 30). Del total, aproximadamente 21 comunas son caracterizadas como ancestrales por tener título de propiedad comunitaria de sus tierras, ejercer prácticas culturales propias, mantener autoidentidad de sus descendientes, disponer de cabildos y estatutos registrados y actualizados (Andrade 2013, 13). De estas comunas, quince están asentadas en las tierras comprendidas entre la planicie de Turubamba al sur, los valles de Los Chillos al suroriente y de Tumbaco al nororiente, y en las laderas que rodean a la montaña del Ilaló; cinco están asentadas en el flanco noroccidental del macizo del Pichincha, y tres están localizadas en el centro y sur de la ciudad.

Desde la perspectiva indígena, el pueblo kitu kara está formado por cerca de noventa comunas y comunidades, situadas en las parroquias rurales y urbanas del cantón Quito, y en algunas parroquias rurales de los cantones Rumiñahui y Mejía (Pueblo Kitu Kara 2016, 12). Las comunas integran diferentes OSG, entre las cuales están la Unión de Organizaciones Indígenas y Campesinas de Nono, Unión de Organizaciones Indígenas y Campesinas de Pifo, Unión de Organizaciones Populares de Pifo, Comuna San José de Cocotog, Coordinadora de Comunidades Ancestrales del Noroccidente de Quito, y Unión de Organizaciones Indígenas y Campesinas del Cantón Mejía (Murillo 2008, 110).

Las comunas indígenas tienen vínculos con la ciudad mestiza desde las épocas colonial y republicana, manteniendo una continuidad 
histórica de nexos propios del mundo norandino de "reciprocidad asimétrica" con el sistema de hacienda, el poder local y la ciudad. Han sido proveedoras de alimentos, trabajo, cultura y contribuyeron a configurar el modo de vida quiteño, lo que les ha posibilitado, en una relación de complementariedad, preservar la forma comunal.

Desde el origen colonial de la ciudad los profesionales, canteros, carpinteros y albañiles indígenas fueron maestros y practicantes de oficios relacionados con la construcción de los "edificios monumentales y el trazado urbano quiteño" (Webster 2012, 10). La construcción de las iglesias, edificios públicos, residencias, casas solariegas, calles, plazas, así como las obras emblemáticas del ornato y la iconografía cívica y religiosa quiteña, deben su calidad a los diestros oficios indígenas. Sin embargo, pese a la existencia en las Actas del Cabildo de los siglos XVI y XVII de información detallada sobre los apellidos y oficios indígenas, su aporte a las obras patrimoniales ha sido velada por el uso del anónimo genérico de "la mano de obra indígena" (17).

Ya en la Colonia los indígenas de las comunas prestaban servicios a la ciudad y se establecieron especializaciones de los oficios según los lugares: los de la zona de Zámbiza se encargaban de la limpieza de la ciudad, los de Nayón de encender los faroles del alumbrado de las calles, los de "La Magdalena, Chimbacalle y Chillogallo eran cargadores, criadores de mulas y arrieros para el transporte inter-regional; los de Conocoto era picapedreros y albañiles", explica el historiador Frank Salomon $(2007,37)$.

Modernamente, las contribuciones de los indígenas al urbanismo quiteño, pese al anonimato, también han sido fundamentales, por ejemplo, en el levantamiento de hitos urbanísticos "republicanos" como el parque de La Alameda, el Teatro Sucre y el Observatorio Astronómico, que fueron edificados con trabajo subsidiario y gracias a las destrezas de maestros y albañiles de las comunidades de Santa Clara de San Millán, La Magdalena, Guápulo y Tumbaco; del mismo modo, el servicio municipal de barrido de calles y limpieza de acequias continuaba a cargo de los indios zámbizas provenientes de las comunas de Llano Grande, Llano Chico, Nayón, Cocotog y Zámbiza (Kingman 1992, 33-4). Hasta 
entrados los años 60, era común que los "guangudos", como peyorativamente se denominaba en la retórica mestiza del quiteñismo a los indígenas de la zona de Zámbiza, vestidos con rústicos overoles grises y calzando oshotas, una suerte de uniforme municipal, recorrieran las calles del centro y de los primeros barrios pericentrales, anunciando con campanas su paso, mientras barrían las calles y recogían la basura.

A mediados del siglo XX el sistema de mingas, institucionalizado como una modalidad pública de trabajo para los indígenas de las comunas, fue usado por los primeros alcaldes, bajo el mecanismo de conscripción vial, lo que permitió la apertura y pavimentación de nuevas avenidas y calles de la ciudad, así como emprender con numerosas obras públicas municipales (Goetschel 1992). En esos años los indígenas, diestros en oficios con dominio de tecnologías y saberes constructivos ancestrales en materiales como barro, adobón, bareque, madera, tejas, estructuras de carrizo y demás, también construyeron las vistosas ciudadelas jardín promocionadas por la Caja del Seguro: La Villaflora en el centro sur, La Vicentina y La Floresta en el costado centro-oriente y todas las ciudadelas del centro norte como el barrio América, San Juan y Belisario Quevedo (1992).

Pese a su relevancia, los oficios de albañilería siempre estuvieron en el lado opuesto del privilegio, fueron parte del discrimen y la "falta de respeto" que inferiorizaba a sus practicantes, estigmatizados por su cercanía a lo ancestral, como lo evidencia el testimonio recogido por Kingman: "Ser albañil, negociante de animales, vendedora de mercado era ocupar los últimos lugares en la escala social ya que eran consideradas ocupaciones de indios" $(2006,225)$. Eran oficios desvalorizados cultural y económicamente por su progenie ancestral.

Debido a sus destrezas constructivas, los maestros y albañiles indígenas son imprescindibles en la restauración y conservación del patrimonio edificado de la capital, declarado Patrimonio Histórico de la Humanidad por la UNESCO, por lo que los oficios de albañilería han sido y son estratégicos en la conservación de las edificaciones quiteñas. De acuerdo con la autopercepción del pretérito gremio de albañiles de Quito, la albañilería posibilitó la continuidad de los "saberes prácticos", 
traspasados a sus descendientes y actualmente imprescindibles en las políticas de conservación del patrimonio edificado pues, a diferencia de los inmediatistas profesionales de la construcción, "los albañiles, y de manera específica los viejos maestros, serían los depositarios de la tradición urbanística y arquitectónica de la ciudad", afirma Eduardo Kingman $(2006,227)$. En medio de un ambiente hostil, los indígenas continúan aportando con sus saberes ancestrales, tecnología y oficios constructivos en las edificaciones de la ciudad.

En la actualidad virtualmente la generalidad de jardineros, jornaleros y trabajadores del gobierno municipal provienen de las comunas cercanas a la ciudad, especialmente de las zonas de Zámbiza y Calderón, dando continuidad a la sui géneris condición de comuneros que se desempeñan como funcionarios públicos municipales, como lo explica el antropólogo representante del pueblo kitu kara, Freddy Simbaña:

En el sector de Zámbiza, en el sector de Calderón, son comuneros con su comuna, con estatutos, con cabildo comunal donde se toman decisiones, pero al mismo tiempo los comuneros están en el sector público, están en la Empresa Municipal de Agua Potable, en la Empresa Municipal de Alcantarillado, están también en la Empresa Eléctrica Quito. Es una vieja relación que tienen las comunas con el Municipio de Quito, porque quienes podían hacer mejor estos oficios, quienes conocían los territorios eran las poblaciones indígenas y campesinas de la ciudad. (2015, entrevista personal)

Las relaciones de las comunas con la ciudad, haciendas y fincas no estaban exentas de conflictos por la posesión de tierras ejidales, de disputas por las fuentes y caudales de agua. Hay evidencias y testimonios de largos juicios de tierras y aguas en las comunas de Santa Clara de San Millán, La Magdalena, Lumbisí (Kingman 1992), incluso sobre la propiedad de las tierras comunales de El Panecillo, en pleno centro de la ciudad. Dada la escala de la urbe, hasta fines de los años 60, las tensiones con las comunas se reducían a las disputas en torno a los límites y posesiones de predios, y eran tratadas en condiciones que no amenazaban su existencia, en parte debido a que se encontraban relativamente distantes del perímetro urbano. 
Con la expansión metropolitana de la ciudad, en las últimas cinco décadas, la relación espacial de las comunas cambió de modo drástico e irreversible, amenazando incluso su existencia. En poco tiempo, las dinámicas territoriales que transformaron las zonas de tradición agropecuaria en nuevas áreas residenciales y comerciales, estimuladas por el mercado inmobiliario y el tráfico de tierras, alcanzaron a las comunas. Antiguos graneros en los valles y planicies de Los Chillos, Tumbaco y Turubamba desaparecieron convertidos en barrios, lotizaciones, ciudadelas y centros comerciales que han dado lugar a nuevas centralidades urbanas; asimismo, viejos sistemas de andenes y terrazas localizados en el sur de la ciudad, otrora en producción agrícola intensiva, han sido devastados igualmente para dar paso a nuevas urbanizaciones, extensos planes de vivienda y barrios periféricos (34-5).

Buena parte de la ciudad moderna se ha levantado sobre los restos arqueológicos de las culturas originarias, borrando los patrones de asentamientos territoriales norandinos. Los vestigios conservados han sido hallados en terrenos públicos, mantenidos en calidad de museos de sitios como en el Parque Arqueológico y Cultural Rumipamba, el Museo de Sitio La Florida, los vestigios encontrados en Cotocollao y en el sector de El Condado que pertenecerían al Período Formativo, el Museo de Sitio y Centro Ceremonial Tulipe, las ruinas de Catequilla, entre otros. Pese a la devastación del patrimonio arqueológico, en la ciudad y en las parroquias rurales del distrito hay alrededor de 1500 sitios arqueológicos prehispánicos, que están registrados en los tres tomos del Atlas arqueológico de Quito (Jara 2009), y son evidencia de la riqueza cultural de los pueblos originarios.

Las comunas han sido impactadas de distintas maneras por la expansión metropolitana, algunas de ellas han desaparecido, otras corren el riesgo de disolverse y las demás resisten. La presión por la compraventa del suelo comunal, por parte de los agentes del mercado inmobiliario, afecta la vida comunitaria al fragmentar la propiedad colectiva de la tierra, debilitar el control comunal de los recursos naturales ejercido por los cabildos y desarraigar las relaciones de afinidad entre los comuneros. Cada vez más gente ajena a la vida de las comunas se asienta en sus in- 
mediaciones y, dentro de ellas, en condominios privados cerrados, en lotizaciones exclusivas en torno a viejas casonas de haciendas y en viviendas unifamiliares, cimentando estándares de vida urbana que presionan la dotación de servicios, masifican las demandas de consumo, imponen estilos educativos de ascenso social y prácticas culturales individualistas.

Es el avance metropolitano que arrincona a las comunas por medio de las clases medias y acomodadas que se asientan en los valles circundantes, nostálgicas de un estilo señorial endosado por un imaginario ajeno. Al replicar los estigmas mestizos de inferioridad de la pobreza, los nuevos residentes desconocen a las comunas y sus costumbres, provocando conflictos étnicos con la población local. Por cierto, también se han formado barrios populares y periféricos en las inmediaciones y territorios de las comunas, especialmente en tierras de las tres comunas que se encuentran dentro de la ciudad, donde tienden a asentarse los migrantes indígenas que reproducen las prácticas comunitarias y familiares, atenuándose los conflictos culturales.

Kingman $(1992,37)$ a comienzos de los 90 advirtió el riesgo de disolución de las comunas como consecuencia de la presión del mercado inmobiliario y de la inercia de las autoridades y procedimientos municipales que, en función de legalizar los nuevos barrios para dotarles de infraestructura, servicios y equipamiento urbano, promovían la conversión, muchas veces innecesaria, de las zonas rurales en áreas urbanas, sin ninguna consideración de la realidad de las comunas, no obstante la existencia de instrumentos jurídicos expresamente destinados a la defensa de sus territorios.

Dos décadas más tarde, la tendencia de expansión urbana metropolitana continúa arrinconando a las comunas, pese a los mandatos de la Constitución de 2008 que establecen a las comunas como titulares de derechos colectivos, ratificados y ampliados en la extensa normativa orgánica de planificación, ordenamiento territorial, autonomías y descentralización vigente, esto es en el denominado "derecho urbanístico y territorial de las comunidades ancestrales del distrito metropolitano de Quito" (Andrade 2013, 13). Contrastando los datos del registro de comunas, se colige que un tercio de las comunas del distrito no están pa- 
sivas, sino que se han extinguido por causas vinculadas con la expansión urbana y la propia inviabilidad de las comunas de reciente formación, integradas por campesinos mestizos autoadscritos como originarios, como ocurrió con las comunas de Tanda, Alambi y Alaspungo.

A pesar de la densa normativa que salvaguarda sus territorios, las comunas no siempre lograron remontar los obstáculos que se les presentaron en el manejo productivo de sus tierras, otrora administradas en el sistema de hacienda, como aconteció con algunas de las comunas campesinas formadas a inicios de los años 70 que experimentaron "ciclos de auge y extinción", debido a factores estructurales y complejas negociaciones que debieron enfrentar después de la reforma agraria (Figueroa 2012). Las comunas tal vez son intrínsecas a lo indígena, en tanto se mantienen junto a sólidas adscripciones identitarias, pero no son necesariamente inherentes a los campesinos, trabajadores rurales y al mundo popular, como ocurrió con las comunas de Alaspungo y Alambi en la zona de Nono, al noroccidente del distrito metropolitano, estudiadas por Figueroa (2012). Allí, los campesinos formaron precooperativas que no prosperaron, luego se constituyeron en comunidades como requisito legal para el acceso a la tierra, tras diez años en un caso y siete en el otro tampoco se consolidaron, convirtiéndose en barrios rurales, y la tierra se fraccionó en propiedades individuales.

En principio el trabajo comunitario permitió responder a las necesidades con mingas para cultivos, cría de ganado y hasta intercambios no monetarios, pero fue desbordado por las dinámicas familiares que en la práctica son las unidades productivas reales, volviéndose forzosas las obligaciones comunitarias. La falta de títulos de propiedad limitó el incremento de moneda circulante, y la tendencia a la ganadería presionó a que los más prósperos compren tierras y expandan las pequeñas propiedades ganaderas, factores que en conjunto debilitaron a la propiedad comunal. La población local envejeció, se desarticularon las iniciativas organizativas y los trabajadores fueron expulsados a los barrios periféricos del noroccidente de la capital, especialmente a La Mena del Hierro, Santa María, San José, San Miguel, Santa Rosa, el Mirador del Noroccidente, a las cooperativas Jaime Roldós y Pisulí, entre otros (48-67). 
Las comunas son un tema extensamente debatido en la literatura académica, según Figueroa (2012) está influenciado por las tradiciones vanguardistas que ven en ellas alternativas populares, basadas en un comunitarismo que no considera los intereses individuales y sus nexos con otros intereses grupales, por las visiones que se enfocan en que su existencia requiere resolver las causas estructurales de los problemas, y los factores de naturaleza sociopolítica y cultural. En cualquier caso, la comunidad como proyecto político requiere un seguimiento y una evaluación permanentes, lo que implica la cimentación de una "esfera pública popular" (54), explica el autor.

Más aún, cuando la experiencia de las comunas ocurre en las interfases territoriales del campo y la ciudad, asentadas la mayoría en territorios periurbanos, y en condiciones en que su devenir está condicionado por las fuerzas inmobiliarias que presionan al suelo urbano con la expansión metropolitana. En el territorio del DMQ el suelo urbano representa apenas el $8 \%$, el suelo urbanizable el $2 \%$ y el suelo no urbanizable el $90 \%$, que corresponden a ecosistemas protegidos con recursos renovables y no renovables, o son zonas topográficamente no aptas para la construcción (CIUDAD 2012, 17). Coincidentemente, las comunas están asentadas en la mayoría del suelo potencialmente urbanizable de Quito.

Las interfases rural urbanas no ocurren solo en los ámbitos económicos y territoriales, también acontecen entre las racionalidades organizativas en las que coexisten comunas y barrios conjuntamente con cabildos y comités promejoras, entramados que, vistos de cerca, evidencian tensiones porque sus dinámicas organizativas obedecen a intereses disímiles y contrapuestos. Los comités promejoras tienen un sentido pragmático de resolver necesidades materiales inmediatas, los barrios como agrupaciones viviendísticas de origen compartido devienen en individualidades residenciales transitorias, como analicé en el capítulo anterior. Las comunas, en cambio, operan como agregaciones comunitarias asentadas en el control colectivo del territorio, los recursos y las decisiones que incluyen la vivienda y van más allá; en tanto entidad social integran dinámicas económicas, territoriales y culturales. Es para- 
dójico que en los mismos entornos espaciales, mientras en las comunas se resiste a la individualidad urbana, en los barrios y comités promejoras se busca la inserción individual en la ciudad.

Algunas comunas del distrito metropolitano en realidad son barrios periféricos que funcionan mediante comités promejoras, como ocurre con las de reciente formación y autodeclaradas comunas: Horizontes del Norte, Ayachul, Uyachul Alto, Catzuquí de Velasco, La Leticia, Catzuquí de Moncayo y Huertos Familiares Santa Isabel de Rundupamba, asentadas en la ladera noroccidental de la ciudad, y agrupadas en una OSG autodefinida como de "comunas ancestrales", integrada por siete barrios y sus respectivos comités promejoras (19). Al analizar las necesidades expuestas en el plan de mejoramiento de la Coordinadora de Comunidades Ancestrales del Noroccidente de Quito, es claro que se trata de demandas por infraestructura, servicios y equipamiento propias de los barrios periféricos y que forman parte de la agenda de hábitat popular; no hay reivindicaciones propiamente comunitarias.

Asimismo, al revisar los problemas que priorizaron, se ratifica que son los que aquejan a todos los comités promejoras, especialmente la poca participación de la gente y la desconfianza en la OSG (52-3). Las comunas quiteñas tampoco representan un cosmos uniforme, muestran un espectro de realidades culturales disímiles, organizativamente son distintas y socialmente son heterogéneas.

Las relaciones de las comunas con la ciudad, desde la perspectiva del pueblo kitu kara pueden agruparse en tres momentos diferenciados, explica Simbaña (2015). El primer momento corresponde a lo que él ha denominado "autogestión comunitaria andina", esto es cuando la economía familiar era el núcleo de la vida comunitaria y se combinaba la cría de ganado con la agricultura y los oficios o artesanías. Se mantenía la propiedad comunitaria de la tierra y de un hábitat comunal en el que se ejercía el manejo vertical de los pisos andinos: las partes altas estaban destinadas al pastoreo, la parte media para los cultivos especialmente de ciclo corto, y la baja para la vivienda y cultivos anuales, desde allí se controlaban las actividades productivas. Simbaña considera que todavía hay prácticas productivas andinas en las comunas de Santa Clara de San Millán, Chilibulo 
y Miraflores dentro de la ciudad de Quito, donde se armoniza el pastoreo con cultivos y oficios. "Este momento de autogestión comunitaria funcionaba hasta fines de los años 70”, comenta (entrevista personal).

El segundo momento, caracterizado como de "transición comunal”, empieza en los años 80, con las presiones a las comunas derivadas de la formación de las ciudadelas y urbanizaciones en sus inmediaciones. Es un período en el que se expresan con fuerza las luchas populares por la vivienda más que por la tierra, protagonizadas por los "migrantes de segunda y tercera generación a la ciudad capital”. En este nuevo momento la comuna pasó a un segundo plano y adquirieron relevancia los comuneros y sus familias, pues vieron la necesidad de los oficios y no de los cultivos o el pastoreo, que perdió importancia económica.

Las presiones derivadas de la construcción de las urbanizaciones generaron demandas de mano de obra en las comunas que reactivó la tradición histórica de proveer maestros constructores, albañiles, carpinteros y tejeros para la expansión de la urbe. Este segundo momento duró dos décadas y llegó hasta fines de los años 90, en los que la propiedad comunal de la tierra fue más simbólica, estuvo relacionada con la naturaleza y no con la economía (entrevista personal). El período coincide con las presiones inmobiliarias advertidas, que debilitaron a la organización comunal, precipitando el fraccionamiento individual de la propiedad de la tierra.

Fue el tiempo de adaptaciones económicas de los comuneros, en el que surgieron o revivieron ciertas actividades especializadas en algunas comunas como los tejeros de La Magdalena, los albañiles de Chillogallo, los viveros de plantas ornamentales y jardinería de Nayón, los transportistas escolares de Llano Grande y Llano Chico, las artesanías de crin de caballo de Guangopolo, las de mazapán de Calderón, entre otras. Se trata de la funcionalidad de las comunas a otra economía, influenciada por las transformaciones metropolitanas. Los oficios tradicionales de los comuneros estimularon el surgimiento de las economías de servicios, permitieron capitalizar ahorros y emprender micronegocios, por ejemplo, dice Simbaña: "se empieza adquiriendo una buseta para el transporte escolar, con el paso del tiempo hay más busetas y se forman cooperativas de transportistas entre la gente de las comunas" (entrevista personal). 
En los últimos años han surgido múltiples negocios particulares en las comunas: papelerías, tiendas de abastos, restaurantes, picanterías, almacenes de ropa, de artículos electrodomésticos, bazares, etc., generalizándose la dinámica del comercio, sin que ello signifique perder la comunidad. Los comuneros "continúan asistiendo a las reuniones, a las mingas, hacen los traspasos simbólicos de los terrenos a las nuevas generaciones, son priostes y participan de la comuna" (entrevista personal). Se mantiene la cultura pero con otras formas de apoyo, "si no pueden asistir a las migas, pagan para que el que no tiene sea compensado", lo que es asumido como una forma de "trabajo al partir", que está enraizada en las tradiciones agrícolas. Es otra modalidad de reciprocidad andina, por la que quienes tienen ingresos en la economía de servicios contribuyen al sostenimiento de la comuna y subsidian, podría decirse, a los que todavía continúan en la agricultura que son los "guardianes de la comuna":

Entre las personas que se han especializado en la agricultura, y otras personas que han dejado este vínculo, lo que hacen es sostener el proceso comunitario. Quienes están siendo los guardianes de la comuna, son los que están siendo sostenidos por toda la parte de abajo, a través de las personas que tienen sus pequeños negocios, que dan para que la comuna se mantenga. Es lo que llamaba, de una manera simbólica, como la fiesta que contiene una manera de ver el mundo y que se expresa de forma contemporánea. Es la continuidad de la comunidad con otras herramientas. (Entrevista personal)

Los oficios de los comuneros no son simple mano de obra, advierte Simbaña, representan la relación fluida entre los saberes locales y la memoria de la ciudad, que a su vez expresan los nexos entre lo social y la naturaleza en el aprendizaje del oficio. Es la continuidad entre "oficio, cultura y arte en la ciudad", recogida en la memoria de los comuneros: "Al momento que se ejerce el oficio, que da su trabajo, el sentido de la comuna queda simbólicamente en ese espacio construido", sentencia Simbaña (entrevista personal).

El tercer momento es el "proceso de autoidentificación", cuando el tema de lo ancestral se empieza a debatir, fruto de la influencia del movimiento indígena. Si bien a lo largo de los años 90, en los sucesi- 
vos levantamientos y marchas indígenas que tuvieron como referente simbólico la toma de Quito, el movimiento indígena montó el discurso de las identidades de las nacionalidades y pueblos sobre la base de la propiedad y control territorial, fue en el levantamiento del año 2000 que se empezó a construir una "cierta discursividad" desde las comunas para el DMQ. El auge del movimiento indígena contribuyó a eslabonar un discurso de identidad étnica, que articuló la autoidentificación de las comunas en el territorio distrital, proveyó de ciertas ramificaciones ideológicas sobre la ancestralidad que permitieron generar la noción de territorio entre ellas. La influencia del movimiento indígena hizo posible valorar la autentificación de la pertenencia al lugar que reclamaban los mayores, es a lo que se refiere Simbaña cuando dice:

la pertenencia de las abuelas, la de los abuelos de Quito era lo que tenían, porque cuando se le pregunta a una abuela, a un abuelo de un barrio tradicional, que no significa que es de cuarta o quinta generación, por ejemplo de La Magdalena o Chilibulo, se le pregunta: ¿De dónde llegó? Y dice: no llegué de ningún lado, soy de aquí. Ese aquí significa una pertenencia. En ese momento histórico, lo que reivindican las comunas en el año 2000, con el movimiento indígena, era lo que en lo cotidiano hablaban los abuelos. (Entrevista personal)

Corría el año 2000 cuando Ecuarunari convocó a la primera reunión de parroquias rurales y comunas de Quito, con el propósito de constituir una base logística de soporte para sus levantamientos, si bien los grupos eclesiales del sur y los barrios periféricos del noroccidente habían apoyado las entradas a la capital de las marchas indígenas, se buscaba un puntal proporcionado por los indígenas de Quito y que, al mismo tiempo, reivindicara sus propios espacios. La Federación de Pueblos Indígenas de Pichincha, que para entonces ya funcionaba con integrantes de las parroquias de Nono, Calderón, Zámbiza, Nayón y Pomasqui, realizó la primera reunión preparatoria para posicionar el tema de las nacionalidades y pueblos, considerando al movimiento indígena de Quito. $\mathrm{Al}$ comienzo, al interior de la Federación de Pueblos Indígenas de Pichincha, el pueblo kayambi tenía la iniciativa y predominaba con su propio espacio organizativo. Poco a poco las comunas de Quito comen- 
zaron con su proceso de recuperación de la memoria, investigando en archivos y debatiendo entre las organizaciones sobre su pertenencia a la ciudad, hasta que se convocó a un segundo congreso de la federación con el propósito de ratificar que esta se mantenga como la organización matriz y se reconozcan en su interior a los dos pueblos de la misma nacionalidad kichwa: el pueblo kayambi y el pueblo kitu kara (entrevista personal).

Más tarde, cuando el pueblo kitu kara se afilió a la CONAIE y a Ecuarunari, se estableció una suerte de "cláusula" condicional de que se encuentra en "proceso de reconstitución", lo que implicó un desafío cultural, lingüístico e histórico para su fundamentación y caracterización; no obstante, "se socializó en todos los espacios que ya había una célula madre Kitu Kara, una estructura organizativa y una sede de gobierno como parte del Ecuarunari” (entrevista personal). Junto con el Consejo de Desarrollo de las Nacionalidades y Pueblos del Ecuador (CODENPE), surgió el asunto de las comunas ancestrales quiteñas como algo contemporáneo, vinculado con la ruralidad. Esos temas habían sido tratados de alguna manera anteriormente, cuando empezaron los encuentros interparroquiales del distrito metropolitano; si bien se daban en un marco institucional municipal, se aprovechó para articular en algunas parroquias la temática de la ancestralidad de las comunas, generalizándose luego como su referente identitario, recuerda Simbaña (entrevista personal).

Con el reconocimiento y legitimación del pueblo kitu kara por parte del CODENPE en el año 2003 (Pueblo Kitu Kara 2016, 12), su discursividad cambió, abriéndose un intenso debate sobre lo andino y lo urbano: una postura planteaba resistencia a la integración a la ciudad, otra posición de corte indigenista reivindicaba retomar exclusivamente lo andino, y estaban los partidarios de que se debía mantener la ruralidad considerando que es una ciudad metropolitana. Los debates provocaron tensiones entre las comunas, algunas no admitían la colaboración con el municipio de Quito, otras disputaban la sede de la educación bilingüe, varias parroquias rurales dejaron de participar y las comunas de la ciudad eran vistas como no indígenas. Detrás de las tensiones estaba la visión de que la identidad depende del territorio: "se es más indígena cuando se está fuera de la ciu- 
dad y se es menos indígena porque se está en la ciudad, cuando la cosa es más compleja”, reflexiona Simbaña (entrevista personal).

El debate identitario no fue solo entre las comunas sino respecto de la ciudad, y cuestionó también a la genérica identidad quiteña. Se argumentó, acertadamente, que no son equivalentes las adscripciones de los habitantes a sus barrios, a las identidades étnicas del pueblo kitu kara y sus comunas; mientras las primeras aluden a anónimos ciudadanos cuya identidad se relaciona con su transitoria pertenencia al barrio, las segundas refieren a situaciones más complejas enraizadas en la historia de la ciudad, y en el presente implican un tupido dinamismo cultural. Ante la genérica identidad quiteña, el pueblo kitu kara propuso, en palabras de Freddy Simbaña:

Un diálogo para descolonizar la quiteñidad. Había una cierta manera, cierta estructura de lo que es ser quiteño. Pensábamos que si logramos que vayan confluyendo varios discursos sobre quiteñidad, estaríamos aproximándonos a las identidades aquí en la ciudad. Es decir, el quiteño tiene varias identidades, pero la historia nos hizo conocer solo una: la del Terrible Martínez, La Torera, lo colonial, lo señorial, que impregnó a lo quiteño. Con estas otras articulaciones lo que se quiere es que se vayan construyendo, en la misma quiteñidad, otras formas de expresión que puede ser la ancestralidad, que puede ser lo cultural, que puede ser el Pueblo Kitu Kara, y eso incluye también a las diferentes identidades afroecuatorianas y montubias. (Entrevista personal)

El diálogo descolonizador planteado subvirtió las imágenes y valores del quiteñismo. Aunque buena parte de su iconografía ya no calce en los imaginarios individualistas predominantes, continúa usándose como hitos públicos referenciales de la ciudad, impulsados principalmente por el municipio capitalino empeñado en una memoria homogénea del progreso urbano, y sus intrínsecos valores discriminatorios y racistas calaron hondo como parte del sentido común en las nuevas generaciones quiteñas. La postura crítica del pueblo kitu kara propone la recuperación de las múltiples dinámicas culturales locales, que en la práctica cotidiana configuran las identidades quiteñas, inquiriendo en la memoria de la ciudad para develar lo no dicho, sobreponiendo a los ocultamientos de la diferencia cultural la valoración de lo ancestral, 
enunciada no desde la frontera vergonzante del mestizaje, sino en diálogo con una memoria plural en la que se expresen otras voces nutridas por las diferentes visiones y experiencias de una quiteñidad diversa.

El pueblo kitu kara se encuentra dedicado a la revitalización cultural y al fortalecimiento de su identidad. Investiga sobre sus mitos fundacionales y el simbolismo andino, expresado en las vestimentas de las comunas de las parroquias rurales del distrito, para lo cual estimula la reconstrucción de los atuendos habituales con sus metáforas de seres naturales y recupera las memorias ancestrales de autoidentificación de lugares cercanos entre sí, pero con importantes singularidades culturales (2015).

Igualmente está enfocado en caracterizar las lenguas nativas respecto del uso de la lengua kichwa. Entre los pueblos originarios hubo lenguas preincásicas como el safique, yumbo y chachi panu, y hay lugares en los que se autodeclaran "prekichwas" como en Cotocollao y Calacalí, donde se va configurando una cierta microidentidad en torno a esa adscripción (2015). No es una veleidad académica de sus dirigentes, sino un interés práctico para fines de cohesionar la organización como parte integrante de la nacionalidad kichwa y fortalecer el uso de la lengua kichwa unificada como elemento articulador, pues junto con la recuperación de la lengua está el fortalecimiento de los saberes locales y la educación bilingüe intercultural.

Otra de las preocupaciones centrales es el territorio ancestral de las comunas, convertida en demanda de "nueva territorialidad" en el distrito metropolitano, en pos de restituir y compensar los "despojos y desplazamientos territoriales de las comunas", fortalecer la propiedad comunal frente a la propiedad privada, y una política municipal tributaria acorde con la realidad de los territorios comunales (13-4). Las expectativas del pueblo kitu kara están recogidas en su agenda política que tiene como objetivo: "proponer lineamientos de políticas públicas para visibilizar la presencia del Pueblo Kitu Kara en el marco de la construcción de DMQ como una ciudad incluyente, plurinacional e intercultural” (11).

La agenda tiene los siguientes siete ejes de políticas públicas. 1. Propiedad, centrada en la categoría de territorio comunal incorporada decididamente en el Registro de la Propiedad. 2. Ambiente, por medio 
de un subsistema de áreas protegidas y territorios ancestrales en cogestión con las comunas y comunidades, y su respectiva declaratoria. 3. Autoridad, garantizando el pleno ejercicio de los derechos de los gobiernos comunales y una cultura de servicio público que incorpore los derechos colectivos a los funcionarios en los territorios. 4. Planificación del ordenamiento territorial comunal, que conecte las aspiraciones de los pobladores y ciudadanos de las comunas con la política pública. 5. Cultura, enfocada en desarrollar las políticas culturales, la construcción lingüística y simbólica, y la resignificación de los espacios públicos del pueblo kitu kara. 6. Participación con un modelo que garantice a las comunas como autoridades territoriales en el sistema de participación ciudadana y promueva dispositivos de exigibilidad de los derechos colectivos. 7 . Justicia, con espacios de coordinación entre autoridades comunitarias y públicas para administrar la justicia indígena, con depósitos judiciales propios de las comunas (Pueblo Kitu Kara 2016, 22-5).

La agenda política quiere cohesionar a las comunas ancestrales quiteñas, que, como se ha insistido, se muestran abiertas a la diversidad cultural en el distrito metropolitano, porque a su interior también son disímiles, pues el pueblo kitu kara no está legitimado en todas las comunidades del distrito (Murillo 2008, 116), identificándose al menos tres variantes, según lo reseña Freddy Simbaña. Una primera ramificación es la estructura base vinculada al proyecto político del pueblo indígena, dispone de infraestructura, un consejo de gobierno, tiene dirigencias, reuniones, actas y opera mediante su filiación a la CONAIE.

Una segunda ramificación es el denominado pueblo kitus o pueblo kitu, que, con filiación de sangre, reivindica su territorio y una lengua ancestral no kichwa, cuenta con un diccionario chachi panu que los diferencia de los kichwas y se consideran no conquistados lingüísticamente. Sus descendientes están en el norte de la ciudad, entre Oyacoto, Calderón y Cocotog, sus vestimentas están reconocidas por el Instituto Nacional de Patrimonio Cultural y el municipio les dio la personería jurídica (Simbaña 2015).

La tercera ramificación son los que están en la vida cotidiana que he denominado "Kare Kitu, los caras de Quito, porque son el rostro de la ciudad”, dice Simbaña. Son los que viven el día a día, que poco conocen 
de la CONAIE, de las reivindicaciones históricas y territoriales; viven en sus comunidades, manteniendo sincretismos religiosos y rituales, saberes locales y se consideran "de aquí, son los de aquí, personas que tienen descendientes en la ciudad, sin acción política, sin reivindicar la memoria, aunque es un pueblo que está despertándose" (entrevista personal).

Así, el pueblo kitu kara, con toda su diversidad interna, se encuentra en un decidido camino de etnogénesis, volcado en revalorizar lo indígena y lo andino no solo como una demanda de reconocimiento de su identidad, sino con una práctica propositiva de transformación de su memoria frente a la ciudad, evidenciando el perjuicio que provoca en la sociedad y la cultura local persistir en una urbe con una sola identidad uniforme que excluye a muchos.

Quito representa un gran desafío para el pueblo kitu kara, debido a la modernidad colonial que impone condiciones de individualidad económica y fragmentación territorial, que afectan el espacio de las comunas. Avanzar supone la armonía de las comunas y la ciudad, construyendo lo urbano desde y con la heterogeneidad de la sociedad local, para lo cual hay que empezar "descolonizando la quiteñidad para enriquecerla, saliendo de los prejuicios descriminadores y segregacionistas, la identidad quiteña tiene que repensarse", concluye Simbaña (2015).

El destino de las comunas quiteñas pende en parte de sus propias fortalezas organizativas y capacidades de gestión, en parte de las políticas municipales de ordenamiento territorial metropolitano que resguarden la convivencia de la ruralidad en la ciudad, concertando la coexistencia de las comunas con el avance de las urbanizaciones, ciudadelas y barrios. El camino de etnogénesis, emprendido por el pueblo kitu kara, es una reacción a la constante segregación urbana ejercida por el municipio metropolitano, así como una respuesta al estigma de inferioridad que practican los mestizos de la urbe ante la diferencia cultural.

Representa un esfuerzo endógeno de los indígenas de la ciudad en pos de consolidar su identidad andina ante las comunas, ante el gobierno de la ciudad y en medio de la diversa sociedad capitalina, en un momento histórico en que los fragmentados espacios públicos locales obedecen a los impulsos del mercado y a la presión de las empresas e in- 
tereses privados que delinean el curso de la ciudad a inicios del siglo XXI (Murillo 2008, 118). Las comunas quiteñas plantean desafíos políticos, territoriales e identitarios para asumir la diferencia cultural y la diversidad social en la política urbana del proceso metropolitano quiteño.

\section{Inserciones espaciales comunitarias}

En relación con los indígenas migrantes en Quito, un tema extenso y complejo, me limitaré a unas breves reflexiones sobre algunas de sus estrategias de inserción urbana, en un medio metropolitano hostil con lo indio y la pobreza. Las indígenas forman parte del conjunto de migraciones rurales urbanas desde mediados del siglo XIX, con las transformaciones económicas derivadas del auge de la producción y exportación cacaotera, y luego, a comienzos del siglo XX, cuando el ferrocarril conectó la Sierra con la Costa. Esporádicamente, hubo algunos migrantes indígenas en los años 30 en Quito (Swanson 2010). El fenómeno de mayor migración de indígenas a la capital empezó en la década de los años 60, cuando se constriñeron las condiciones de reproducción social en las comunidades indígenas vinculadas a la hacienda tradicional y el "huasipungo" como unidad económica familiar entró en crisis, así ocurrió con las comunidades indígenas de Licto y Flores estudiadas por Carrasco y Lentz (1988).

Los primeros éxodos migratorios indígenas coinciden con el desplazamiento espacial de las clases medias y altas quiteñas, que abandonaron el centro de la ciudad para asentarse en las nuevas urbanizaciones del norte y los valles, con la consecuente desactivación del centro como área económica, el deterioro de sus edificaciones, la invasión de calles por vendedores ambulantes y la generalización de un ambiente de delincuencia e inseguridad. El estropeado centro de la ciudad fue el lugar de arribo de las iniciales migraciones indígenas, abandonado con la expansión metropolitana.

La motivación compartida entre la mayoría de migrantes indígenas al llegar a la ciudad era conseguir trabajo y obtener ingresos lo más pronto posible, por lo que los primeros migrantes se dedicaron a ser estibadores y cargadores en los principales mercados de la ciudad, especialmente en San Francisco, San Roque y Santa Clara en el centro 
de la ciudad, aunque, literalmente, había cargadores indígenas en todos los mercados de Quito hasta entrados los años 90. Si bien todavía algunos continúan en el oficio de carga y estibaje, progresivamente muchos indígenas migrantes se dedicaron al comercio de alimentos, verduras y frutas en consignaciones y de modo ambulante; otros diversificaron las actividades de venta al detal de ropa y accesorios de uso personal; a la recolección y reciclaje de chatarra menor; a la venta de artesanías en tiendas, mercados y de modo callejero, entre otras actividades.

Las migraciones indígenas provienen principalmente de las comunidades de las provincias de Chimborazo, Tungurahua, Cotopaxi, Imbabura y Pichincha. El flujo migratorio sigue un patrón de emplazamiento espacial en los barrios periféricos de los extremos de la ciudad. De acuerdo con mi observación de los asentamientos, encontré que, por ejemplo, los indígenas migrantes tiguas de Cotopaxi se asientan preferentemente en el barrio de Cutuglahua, los de las comunas de Chimborazo en Chillogallo, los de Cayambe en Miraflores y los de Otavalo en Carapungo y Calderón.

Como bien lo ha señalado Jos Demon (2012), no se dispone de información detallada sobre la cantidad de indígenas que viven y trabajan en el DMQ, no hay conteos fidedignos de los indígenas urbanos, cuestión que se dificulta porque varias familias migrantes todavía se registran como comuneros en sus lugares de origen, o por cierta actitud de ocultamiento de la adscripción comunitaria en la ciudad. Demon estima que la población indígena migrante en la capital puede oscilar entre 40 mil y 60 mil personas, una gran mayoría parece provenir de la provincia de Chimborazo (172).

Según un estudio situacional, citado por Demon, realizado en 2005 para la OSG Jatun Ayllu, que congrega a veinticinco organizaciones de indígenas residentes en Quito, tanto protestantes como católicos, dedicados al comercio en tiendas y ambulante, mostró que el 99 \% de sus integrantes procedían de la Sierra: $19 \%$ originarios de la provincia de Cotopaxi y 75,6 \% de Chimborazo (173). Asimismo, de acuerdo con un testimonio recogido en el estudio de Demon, se evidencia que hay 
varios lugares de concentración de la población indígena migrante que ratifican el patrón de emplazamiento espacial:

Nosotros tenemos varios grupos de migrantes aquí. Los de Chillogallo y los de San Roque son de la parroquia de Punín, los de San Martín al Sur y los del barrio Atucucho son de la parroquia de Cacha [...]. Estamos en contacto con un grupo de Cacha que se encuentra por la avenida Amazonas. Hay un gran número de indígenas de Chimborazo por el Camal en el barrio La Ecuatoriana. Y también están los migrantes que se asentaron en San Miguel del Común al norte de la ciudad, que nos dijeron que fuéramos para reunirnos (173).

Los indígenas migrantes residen en los barrios periféricos en condiciones de pobreza, pero sus actividades de comercio ambulante al detal realizan por todas las calles, avenidas, plazas y barrios de la ciudad. En la actualidad, los indígenas migrantes forman parte del paisaje urbano quiteño, es común encontrarles en los lugares de mayor aglomeración de gente, en los sitios de congestión vehicular por el que transitan varias líneas de transporte público, cumpliendo distintas actividades económicas. Lo que empezó como un oficio básico en los mercados de la ciudad, con el paso del tiempo, se convirtió en una inserción ocupacional colectiva y diversificada, en algunos casos exitosa.

Una muestra son los migrantes oriundos de la comuna de Cacha en Chimborazo que, forzados a migrar debido a la erosión del suelo, llegaron a Quito en los años 70 con el propósito de compensar su carencia material, dedicándose a la venta ambulante de verduras y frutas. Cuatro décadas después es sorprendente, dice Demon, "encontrar que en su gran mayoría los indígenas cacheños son propietarios de tiendas de verduras y frutas en los barrios populares del norte y sur de la ciudad" (173). Por medio de las iglesias evangélicas a las que pertenecen conformaron redes de intercambio y ayuda, obteniendo créditos, apoyo legal y capacitación.

Otro grupo que evidencia la capacidad de adaptación colectiva son los indígenas originarios de la comuna de Gulalag, parroquia de Punín, provincia de Chimborazo, quienes igualmente afectados por la erosión del suelo migraron a la ciudad y empezaron como estibadores y cargadores en el mercado de San Roque en el centro de la ciudad, lugar 
de su residencia habitual. Con el tiempo ampliaron sus actividades a la venta ambulante de ropa, mochilas, gafas y accesorios de uso personal en general; cuando el municipio puso en venta los locales en los centros comerciales populares, adquirieron varios, luego compraron once locales en el centro comercial de Chiriyacu al sur de la ciudad, cuatro locales en el centro comercial El Tejar y más locales en otro centro comercial del sur (180), consolidando sus redes comunitarias que combinan el comercio fijo y ambulante.

Estos migrantes se reconocen y funcionan como la Comunidad Gulalag San Roque en todas sus actividades en la ciudad; consiguieron un comodato por diez años para el complejo comunal de vivienda; mantienen una tienda comunitaria de alimentos, una guardería, un taller de confecciones; adquirieron una casa de varios pisos y múltiples habitaciones en el sector de La Magdalena y, recientemente, dos hectáreas de terreno al sur de la ciudad, en el sector La Cocha colindante con el barrio Campo Alegre, donde están empezando a construir un lotización de vivienda para las familias jóvenes indígenas.

Dos factores, señala Demon, fueron decisivos en el grupo de $\mathrm{Gu}$ lalag: uno, que supieron convertir en una ventaja el hacinamiento en que vivían, a costa de las relaciones interpersonales reprodujeron la vida comunitaria en la convivencia, recreando relaciones de reciprocidad y afinidad que les permitió ahorrar y capitalizar para ampliar sus negocios; otro, fue la oportuna decisión de quedarse definitivamente en Quito, por más de tres décadas tuvieron una doble residencia en la ciudad y la comuna, un periódico ir y venir entre el campo y la ciudad, hasta que decidieron quedarse, proyectándose económica y residencialmente en la urbe (189). En ambas situaciones, los migrantes indígenas de Cacha y Gulalag, a más de su condición de católicos y evangélicos, continuaron con sus prácticas culturales comunitarias, lo que les permitió desplegar estrategias colectivas de inserción económica y residencia definitiva en la ciudad.

Los casos son ilustrativos de que los indígenas migrantes, en medio de la marginalidad, se acoplan a la ciudad y dinamizan la economía de servicios, pero la ciudad les segrega, les aísla, como ocurrió en el centro de la urbe. Los indígenas migrantes conviven con mestizos pobres en los barrios 
periféricos de la ciudad, en el Centro Histórico conviven en el barrio de San Roque y en los barrios contiguos, a los cuales el municipio les impuso una barrera de exclusión. En 2003 la política municipal, al sacar a los vendedores ambulantes y restaurar las áreas ocupadas del Centro Histórico, creó una "situación artificial” de mejora en el perímetro nuclear del centro, aislándoles de los barrios pobres pericentrales, en palabras de Demon: "Se conformó una isla de belleza en medio de una región de poblaciones pobres" (174). El complejo habitacional de la Comunidad Gulalag San Roque quedó justamente al borde del perímetro delimitado por las calles La Ronda y 24 de Mayo, que fijaron la frontera espacial de discriminación urbana.

Otra perspectiva contestataria, desde la alteridad de la migración indígena, es la formación de las nuevas identidades de las mujeres jóvenes indígenas que realizan trabajo doméstico en Quito. Asumiendo una "ciudadanización" desde adentro, desde el lado indígena erigen una imagen que corresponde a la generación actual de las jóvenes indígenas ciudadanas, con que impugnan la imagen racializada y "estereotipada" de lo indígena, cimentada "desde la clase dominante”, afirma Ríos (2011, 20). Es la experiencia de las jóvenes migrantes de la comunidad de Atapulo en Maca Grande de la provincia de Tungurahua, que migran temporalmente a la ciudad para desempeñarse como empleadas domésticas y establecen un flujo de nuevas relaciones de adscripción entre el lugar de trabajo, el espacio de socialización y la comunidad de origen.

Para las jóvenes indígenas migrantes los espacios de socialización urbana son los parques de la ciudad, convertidos en lugares de concurrencia de las indígenas domésticas y los jóvenes mestizos igualmente inferiorizados por su condición de pobreza, excluidos ambos de los "espacios legítimos ciudadanos”. Estos parques, en los que se aglomeran ritual y festivamente los pobres de la ciudad, se transforman en los espacios donde, al mismo tiempo que se disipa el origen rural, se enlazan las expectativas urbanas de los excluidos (42).

Es el caso del parque El Ejido, reflexiona Ríos (2011), donde mestizos empobrecidos e indígenas en un acto de subversión del orden social ritualmente recrean sus nuevas subjetividades urbanas, mediante interacciones socialmente marginales pero con "sentidos y significados" 
que contienen la discriminación y atenúan las diferencias étnicas. Indígenas y mestizos, en un juego de la imaginación, crean sus propios espacios de valoración y orgullo.

No obstante, el parque para muchos "mestizos e indígenas de élite" se está transformando en un lugar estigmatizado por la presencia de la gente marginal, en un lugar de riesgo por la concurrencia de indios y empleadas domésticas, en una suerte de "no lugar", aunque para los jóvenes mestizos y migrantes indígenas el parque representa un lugar con sentido e identidad (42-3). El Ejido revela distintos simbolismos, al tiempo que es un sitio representativo de la histórica política liberal, es un referente del ornato de la ciudad, una plaza de exhibición de pintores populares y el terreno de recreación de nuevos sentidos urbanos de los jóvenes indígenas migrantes.

Mientras tanto en el lugar de trabajo, en la casa familiar, parecerían atenuarse las diferencias culturales y étnicas. Allí, las jóvenes indígenas desarrollan mecanismos de adaptación para sentirse "protegidas y cuidadas", usando intencionadamente el bilingüismo kichwa-castellano según las situaciones; visten ropa parecida a la de sus empleadoras, evitan el uso del mandil o uniforme porque ratifica la diferencia cultural y se vuelven diestras en el uso de los electrodomésticos como instrumentos de trabajo. Es un acomodo individual a la modernidad urbana, con el que tratan de reemplazar simbólicamente la relación opresora de servidumbre por la relación ocupacional de "jefa y empleada” (89-98). En los lugares del trabajo doméstico, las jóvenes indígenas migrantes reconfiguran su inserción individual acoplándose con las rutinas de la vida urbana familiar.

En la comunidad, en cambio, las migrantes elaboran nuevas imágenes de jóvenes exitosas, recrean una pragmática manera de juventud indígena moderna, en pos de ampliar su margen de libertad, pues la cultura tradicional indígena es restrictiva con las mujeres jóvenes. Las migrantes, cuando están en la comunidad, montan escenificaciones públicas con el dinero ganado, en torno al simbolismo del gasto en alimentos y ropa, exhibiendo la imagen de que están familiarizadas con el consumo de la ciudad, así: "imaginariamente, se igualan tanto a los ciudadanos y a los indígenas adinerados” (107). 
Detrás de estos juegos simbólicos públicos se encuentran los mecanismos de reciprocidad, resistencia y adaptación comunitaria a la modernidad, expresados en "nuevos juegos culturales" que compensan la "desterritorialización" de la migración, con la territorialización de imágenes locales, pues en estas nuevas representaciones indígenas la singularidad de lo local se vuelve fortaleza, afirma Ríos (109). El flujo de las nacientes subjetividades identitarias entre trabajo, socialización y comunidad, que van recreando las jóvenes indígenas migrantes de Atapulo, revela otra forma de asumir colectivamente la individualización que impone la sociedad urbana, resistiendo y adaptándose desde y con la comunidad a la ciudad, generando inéditos simbolismos juveniles indígenas constitutivos de su inserción en la ciudad.

En condiciones espaciales relativamente distintas, pero en el mismo contexto urbano de racismo e inferioridad de lo indio, otras jóvenes indígenas migrantes también reconfiguran sus referencias identitarias afectadas por la vida en la ciudad, en una singular trama de adaptaciones y continuidades tejidas entre la comunidad de origen y el lugar de trabajo, son las mujeres y niños indígenas mendigos de Calguasig, estudiados por Kate Swanson (2010).

Las jóvenes y niños indígenas mendigos se ven forzados a "negociar diariamente sus identidades", dice Swanson (20), refiriéndose a la compleja situación callejera de los indígenas migrantes que mendigan en la ciudad y confrontan constantemente la estigmatización de la sociedad blanco-mestiza. Atrapados entre las rígidas tradiciones comunitarias y las excluyentes dinámicas ciudadanas, los indígenas mendigos son compelidos a adoptar una forma de "vida disoluta" para adaptarse a la modernidad (21). Se mueven con pequeños márgenes de libertad respecto de las cerradas tradiciones calguasigueñas, con propósitos pragmáticos de rotación en las actividades y la vida callejera.

Calguasig Chico y Calguasig Grande son comunidades indígenas localizadas en la parroquia rural de Quisapincha, en la provincia de Tungurahua, de las primeras que se crearon con la Ley de Comunas de 1937, en calidad de comuna libre, por no estar vinculada a la hacienda, 
sus integrantes siempre fueron propietarios de las tierras por lo que la zona no se afectó con la reforma agraria.

Ha sido una comuna cerrada, con costumbres de vida duramente conservadas, escasamente articulada al mercado económico, que se mantuvo aislada por falta de caminos hasta entrado el año 1992, cuando se construyó la primera vía de acceso. La agricultura familiar es el eje de la economía campesina pero, al igual que ocurre en muchos lugares de la Sierra ecuatoriana, los campesinos han debido complementar su subsistencia con actividades extraagrarias: comercio, servicios, artesanías y migración; en el caso de la comuna de Calguasig, mediante la migración temporal de las jóvenes y niños a las dos ciudades más grandes del país.

La mendicidad es parte de la estrategia comunitaria de reproducción social, dado que se migra de forma permanente y en períodos cortos que reportan recursos familiares. Mientras las mujeres jóvenes y los niños migran, los hombres y mujeres mayores se quedan en la comunidad en labores de pastoreo y agricultura; migran por separado las mujeres y los niños, con el propósito de obtener dinero para adquirir los alimentos de la dieta diaria, cubrir los costos educativos, adquirir ropa, zapatos y bienes (51). La migración a la ciudad y la mendicidad callejera forman parte de una suerte de distribución de responsabilidades familiares para acceder al dinero y los recursos que de otra manera no conseguirían.

La mendicidad se explica por la necesidad familiar de disponer de dinero, migrar para obtener ganancias y ahorrar para adquirir viviendas, animales y satisfacer necesidades básicas, y porque las jóvenes y niños lo pueden conseguir debido a que tempranamente participan en distintas labores: realizan tareas domésticas de cuidado, alimentación y cocina; pastorean el ganado; intervienen en las siembras, cosechas y en la alimentación de animales, por lo que en Calguasig los niños a los diez años están considerados en condiciones de dirigir una familia, han adquirido las destrezas y conocimientos necesarios para "vivir por su cuenta" (124). Calguasig, una comuna cerrada, hostil y desconfiada de los extraños, trasladó esta actitud a las calles, empezó con las migraciones a las plantaciones costeñas en los años 60, enfrentó una abrupta mo- 
dernización en los años 70 y en los años 90 comenzó con las primeras migraciones de mujeres y niños mendigos a las ciudades (130).

En Quito los niños indígenas de Calguasig se involucran en distintas actividades callejeras que les provean ingresos, pasan de una ocupación a otra, hacen de todo: venden chicles, flores, comida, lustran zapatos, cuidan automóviles, trabajan en los mercados, mendigan y actúan haciendo piruetas en los semáforos.

En medio de la complejidad de la problemática de la niñez trabajadora callejizada en Quito, los niños indígenas mendigos están en una situación sui géneris, representan algo menos del 7 \% de los niños trabajadores de la calle y son designados según la categoría municipal como “trabajadores temporales”. En 1997 se estima que eran 200 familias indígenas las que mendigaban en la ciudad, y un aproximado de 500 a 600 niños indígenas de Quisapincha y Pasa mendigaban en condiciones rotativas, la mayoría de Calguasig (152). Conforman una minoría singular del trabajo infantil callejizado que, pese a su condición de población vulnerable, es esquiva a una visión y tratamiento integrales.

El trabajo en la calle se realiza en arduas condiciones de contaminación atmosférica, intensa exposición solar, riesgos de accidentes de tránsito, expuestos a la violencia social y en jornadas de doce horas diarias, luego de lo cual "se apiñan en pequeños cuartos rentados en cualquier sitio, donde de dos a diez individuos comparten colchones de cartón prensado en el piso" (164). Los ingresos son variables pero siempre superiores a las exiguas rentas que deja la agricultura, puede ser más alto que el ingreso que obtienen las niñas y mujeres jóvenes como trabajadoras domésticas, además de que entre los niños indígenas ser mendigo es más valorado que ser empleada doméstica, porque los niños se ven a sí mismos como emprendedores que venden productos (165).

De regreso a la comunidad, las jóvenes indígenas continúan con su educación, pues migran a trabajar de lunes a viernes y retornan a estudiar los fines de semana, con los recursos obtenidos cubren sus costos, además de que adquieren alimentos, ropa y bienes para la familia. Los niños también contribuyen con el dinero ganado para los gastos familiares, complementan los costos de la agricultura, adquieren alimentos, ropa, 
herramientas y cuando logran algún ahorro invierten en mejoras materiales de la vivienda, y realizan las fiestas familiares y comunitarias con cierta “ostentación” frente a la generalizada pobreza de la comunidad.

Detrás de las sonoras festividades están las prácticas de reciprocidad andina, con las que se redistribuyen los recursos en la comunidad, la familia y los individuos. Así, la mendicidad contribuye al sostenimiento de la economía familiar y al mantenimiento de la vida comunitaria.

De ahí que las jóvenes y niños mendigos de Calguasig han perfeccionado sus tácticas de adaptación a los ambientes callejero citadino y familiar comunitario, deliberadamente visten ropas tradicionales cuando están en la comunidad, mudándose de indumentaria conforme las situaciones que viven en la ciudad (174). Al igual que hablan intencionadamente el kichwa o el castellano según las situaciones en la calle y la comunidad, en pos de mantener sus cambiantes identidades en el continuo entrar y salir de los escenarios urbano y rural. La mendicidad para los jóvenes de Calguasig es asumida como un trabajo, en lugar de vestirse con sus mejores prendas, utilizan la indumentaria de trabajo como si fueran a las faenas del agro, se visten convenientemente prendas gastadas y sucias que provocan lástima y los identifica como mendigos.

En la ciudad la creciente inferioridad de los indígenas mendigos les conduce a un aparente callejón sin salida porque, a más de los estigmas racistas de lo indio, están los desprecios a las madres que abandonan a los hijos y la humillación a los propios niños mendigos, lo que ahonda la discriminación. "Lejos de ser víctimas", las mujeres y niños indígenas lidian y tratan las identidades estigmatizadas en la ciudad, pues han aprendido a usar estratégicamente la calle. La mendicidad y venta callejera de chicles se han convertido en medios significativos para enfrentar la pobreza, de ello han hecho su especialidad con elementos "tácticos y performativos", aunque los indígenas de Calguasig siguen siendo pobres, no son los más pobres del país (210).

Para ellos la mendicidad es algo más que una forma de sobrevivir, sus ingresos enlazan cierta ostentación y estatus, la realización educativa y el simbolismo del consumo, pero la ironía es que la mendicidad se convirtió en la forma de enfrentar la pobreza y de adaptarse a la moder- 
nidad; es una manera de salir adelante, dice Swanson (249). Las opuestas situaciones de mendicidad y prosperidad son las caras de la modernidad colonial urbana para los jóvenes indígenas y niños migrantes, al igual que para los demás mendigos de la ciudad.

No obstante, los niños y las jóvenes indígenas han aprendido a manejar sus identidades flexiblemente, en la continuidad que han construido entre la calle y la comunidad, entre la ciudad y el campo, recurriendo al lenguaje, la indumentaria, la educación y el consumo, con los que resignifican su pertenencia paralela a lo rural y lo urbano. Al igual que otros grupos, están redefiniendo el sentido de ser mujeres y jóvenes indígenas en el siglo XXI, en medio de un contexto discriminatorio que privilegia el blanqueamiento y racializa aún más la mendicidad indígena. Sus esfuerzos no escapan a la segregación urbana, pues los "discursos de los derechos de los niños, género, raza y etnicidad”, paradójicamente, argumentan para apartarles de las calles, y aunque ese no sea su propósito, coinciden con la ideología municipal de "sanear la imagen urbana de estos otros individuos" (251), que deben erradicarse y volver al campo de donde vinieron.

De este modo, las experiencias brevemente reseñadas de los indígenas migrantes en Quito son ilustrativas de sus esfuerzos de adaptación en medio de las condiciones adversas de discriminación y racismo que acompañan culturalmente la expansión metropolitana, empeñada en el blanqueamiento y occidentalización de la sociedad quiteña.

Revelan las capacidades de contestación a la modernidad colonial de la ciudad, oponiendo a la individualización ciudadana las iniciativas solidarias de reproducción social. En el camino de alteridad emprendido por los indígenas urbanos en Quito, tres elementos son decisivos: la continuidad de la comunidad en la ciudad, la inserción económica grupal y la reificación de las identidades indígenas urbanas.

Bajo distintas formas, los indígenas migrantes continúan en la ciudad con sus matrices comunitarias de origen. Los provenientes de Cacha, mediante la trama de iglesias evangélicas, mantienen la cohesión comunal; los originarios de Gulalag crearon su propia comunidad de residencia y trabajo dentro de la ciudad, con todos los procedimien- 
tos y ritualidades respectivas; las jóvenes de Atapulo fortalecen desde la ciudad a la comunidad, con el flujo de continuidades y prestaciones; algo similar ocurre con los niños migrantes de Calguasig que aportan a sostener la comunidad con el trabajo callejero. En todos los casos continuar en y con la comunidad posibilita a los indígenas migrantes actuar colectivamente dentro de la ciudad, convirtiéndose, al mismo tiempo, en una forma de resistencia al individualismo y de entrada colectiva en la modernidad.

Las inserciones económicas grupales revelan la vigencia de las instituciones culturales de los pueblos indígenas para el trabajo, inmunes a las oportunidades individuales anteponen las redes familiares, comunitarias y de afinidad con las que establecen contactos, reciben apoyo y realizan las actividades de trabajo en la ciudad.

La inserción grupal en redes como estrategia económica de reproducción social, en condiciones de marginalidad y exclusión, muestra sus potencialidades para los emprendimientos de escala boyantes: las redes de tiendas de los indígenas de Cacha, el complejo de almacenes y puestos volantes de los indígenas de Gulalag, los flujos de socialización de las jóvenes de Atapulo y las tramas callejeras de los niños de Calguasig, son evidencias de una economía popular y solidaria emergente que se construye desde abajo, por medio de redes con continuidades económicas entre el campo y la ciudad.

Finalmente, los indígenas migrantes, en sus esfuerzos por resignificar el sentido de lo indígena urbano, demuestran que la identidad cultural no se pierde al distanciarse del territorio, sino que se recrea con las apropiaciones espaciales de la ciudad: en el uso estratégico de la calle, socializando en los parques, desplazándose por las vías para el comercio, o impregnando de etnicidad los centros comerciales populares, lugares todos en los que la impronta ancestral contribuye a la reificación de las adscripciones identitarias en los nuevos escenarios urbanos.

Dejar atrás la servidumbre opresiva y reemplazarla con las modernas relaciones entre jefa y trabajadora, entre empresario y cliente, en las actividades económicas de los indígenas migrantes, más que exhibir simples valores capitalistas, evidencian los esfuerzos por superar el 
racismo y los estigmas de inferioridad, buscando relacionarse desde la diferencia cultural con sus propias identidades étnicas.

\section{Representaciones identitarias afroquiteñas}

La población afroecuatoriana es predominantemente urbana, la mayoría de negros están asentados en casi todas las ciudades grandes, intermedias, pequeñas y en las cabeceras cantonales. Quito es la segunda ciudad con la mayor concentración de población afrodescendiente del país, cuestión que requiere algunas precisiones.

De acuerdo con las definiciones del Censo 2010, los afrodescendientes incluyen a los negros y mulatos. La población afrodescendiente en el distrito metropolitano se asienta en los barrios periféricos, algunos de los cuales están en las interfases urbano-rural, esto es en las áreas urbanas densamente pobladas, pero todavía con jurisdicción de parroquias rurales, por ejemplo, en Calderón-Carapungo donde habitan 11652 afrodescendientes, Conocoto con 2 711, Tumbaco con 1850 y San Antonio con 1 564, entre otras.

Considerando la continuidad de la mancha urbana capitalina que incluye las 31 parroquias urbanas, y 21 de las 33 parroquias rurales, conforme los datos del Censo 2010, viven en la ciudad de Quito 103677 personas afrodescendientes, que equivalen al $8 \%$ de la población urbana metropolitana y al 4,6 \% del total de la población del distrito metropolitano (INEC 2010a). La casi totalidad de la población afrodescendiente del cantón Quito, esto es el 98 \%, reside en el área urbana metropolitana, y equivale al 88,9 \% de la población afro de la provincia de Pichincha (INEC 2010). Asimismo, los afrorresidentes en la capital corresponden al 13,3 \% de la población afro urbana nacional, y representan el 9,9\% del total de población afroecuatoriana (INEC 2010a).

La ciudad con mayor población afro del país es Guayaquil con 246365 personas, que equivalen al $21 \%$ de afroecuatorianos; la segunda Quito con 103677 personas equivalentes al 9,9\% de afroecuatorianos, y la tercera Esmeraldas con 86968 (8,3\%). Después, en sentido descendente, están varias ciudades: Durán con 25 048, Machala con 21 907, Manta con 16 919, Santa Elena con 12956 y Portoviejo con 12551 
(2010a). La provincia de Guayas es la de mayor población afrodescendiente con 352077 personas equivalentes al 33,8 \% de afroecuatorianos, luego la provincia de Esmeraldas con 234511 (22,5 \%), Pichincha con 116567 (11,1 \%), Manabí con 82260 (7,85 \%) y Los Ríos con 47649 $(4,55 \%)$ afroecuatorianos (2010a).

Solo en las provincias de Esmeraldas y Manabí la población rural afro es mayor que la población urbana, en las demás provincias la población urbana predomina sobre la rural. En términos absolutos, la población afrodescendiente registrada en el Censo 2010 fue de 1041559 personas, equivalentes al 7,1 \% de la población ecuatoriana. De la población afro el 74,3\%, esto es 774486 personas son urbanas, lo que equivale al 8,5\% de la población urbana nacional, y los afrodescendientes rurales son 267073 personas, el 25,7 \% de la población afroecuatoriana (INEC 2010a).

Pese a la documentada presencia de negros desde la fundación española de Quito, de su concurrencia en la historia de la capital y de las importantes migraciones afro en la segunda mitad del siglo XX (Whitten 1995), lo afro en Quito ha sido tratado como algo inexistente, intangible, carente de registro.

Recién con el Censo del año 2000 se tuvieron los primeros datos fehacientes de la población afrodescendiente en Quito, hasta ese momento no se tenían registros oficiales de los negros en el país ni de cuántos habitaban las áreas urbanas y rurales, menos aún sobre los residentes quiteños. Las cifras disponibles eran estimaciones bastante acertadas de las pocas personas que colaboraban y conocían la población afro, especialmente de los misioneros combonianos que promovieron en los años 80 las organizaciones iniciales de afros en la ciudad.

La ausencia de información local de la población afro no se debía solo a una limitación metodológica en el registro, sino que formaba parte de la racialización de la sociedad blanco-mestiza sobre la población afrodescendiente, para la que simplemente no había negros en Quito. No se concebía la posibilidad de que haya negros residiendo en la capital, se presuponía que los que se veían en la urbe estaban de paso y eran 
considerados unos "extraños intimidantes", pues sus lugares propios eran el valle del Chota o la provincia de Esmeraldas, no la ciudad.

Como lo señaló Carlos de la Torre, al negar a los afrodescendientes su condición de habitantes de la ciudad, se los estigmatizó como "invasores o migrantes temporales" que deberían retornar a sus lugares nativos. Negar su presencia forma parte de un arquetipo congelado en el tiempo que arrincona a los negros a la condición de población rural, como habitantes del campo o la montaña, cuestión que también ha sido asumida entre algunos líderes del movimiento afroecuatoriano, con lo que se “invisibilizan las vivencias y experiencias de los negros de la ciudad” (2002, 32).

Los medios de comunicación difundieron el imaginario racializado de las ciudades como los ejes de la identidad mestiza y referentes de la ciudadanía. Con las representaciones negativas de la cultura afro contribuyeron a la configuración de un orden racial en correspondencia con el espacio ecuatoriano: mientras en las ciudades prospera la modernidad porque son el asiento de la población blanco-mestiza, en las zonas rurales pervive la inferioridad racial, el retraso y el salvajismo, dado que están habitadas por los no blanco-mestizos.

Era el sentido central detrás de las representaciones y simbolismos recreados, por ejemplo, en la revista Vistazo analizada por Jean Rahier (1999), que cimentaban la visión de que en las ciudades no caben los negros, dado que son y deben permanecer marginales, constituyen lo que el autor, parafraseando, señaló como el "último otro", esto es no ser parte del mestizaje oficial (75).

Las representaciones mediáticas afro reificaron su naturalizada condición rural, por la que los afros urbanos vistos fuera de su lugar originario eran convertidos en depredadores sociales y asociados con violencias de todo tipo; en cambio en las zonas rurales son asemejados con músicas exóticas, extrañas e inofensivas costumbres culturales (91). Por más de cuatro décadas, la revista Vistazo cimentó un imaginario negativo de lo afro, que apoyó a divulgar el bipolar mensaje discriminador: los negros rurales son pasivos y los negros urbanos se convierten en "peligrosos, salvajes y sanguinarios delincuentes". 
Desdeñado, el pueblo afro devino marginal al proyecto de identidad nacional, cumpliendo el papel del "último otro" en los imaginarios blanco-mestizos, esto es hacer de referente de lo no deseado, de lo opuesto a lo civilizado, por lo que tampoco está en los mitos de "blanqueamiento" de la ecuatorianidad. Es un imaginario nocivo de la cultura afro, convertido por los medios de comunicación en "sentido común nacional", afirma Rahier (106).

La racialización afro está largamente enraizada en los fundadores del pensamiento y de la identidad blanco-mestiza nacional, bifurcándose también hacia los pioneros de las ciencias sociales del país que aseveraron que los afroecuatorianos tenían "predisposiciones innatas a la criminalidad" (De la Torre 2002, 33). El estigma afro, difundido por todos los estratos de la sociedad quiteña, fue interpretado por la policía de la ciudad como la obligación de salvaguardar a los ciudadanos del peligro de los negros, según las declaraciones policiales vertidas a un medio de comunicación quiteño a mediados de los años 90, acerca de la propensión delincuencial de los negros en los barrios pobres (33).

Los primeros asentamientos afro en Quito fueron a raíz de las migraciones rurales provocadas por la reforma agraria de 1964, que desplazó hacia la ciudad a campesinos del valle del Chota y Mira, obligados a trabajar en oficios informales y degradados, los hombres como cargadores en los mercados, peones de construcciones, guardaespaldas, y las mujeres como empleadas domésticas, lavanderas y cocineras (4961). Arrinconados por la doble condición de pobreza y racismo que les imposibilitaba acceder a vivienda digna, debieron establecerse en los tugurios y conventillos de los barrios Las Casas, Pambachupa y Toctiuco en las laderas centrales del Pichincha.

Los negros fueron atraídos por la ilusión de que en la ciudad había oportunidades para mejorar sus vidas, de que ahí encontrarían condiciones de un porvenir para sus familias; no pensaron que la ciudad era discriminatoria con los pobres, excluyente de lo ajeno y violenta con los negros, comenta Ocles:

vemos como toda la gente comienza a salir de sus recintos, de sus comunidades, justamente por eso, por buscar mejores días, puesto que 
muchos de ellos no alcanzaron un nivel de estudio, muchos de ellos eran analfabetos. Por eso pensaron que acá en la ciudad iban a tener la posibilidad de desarrollarse, al encontrarse con un fenómeno que en sus ciudades, en sus comunidades no lo tenían, como que fue cambiando su visión, por ejemplo, el mismo hecho de encontrarse con actos hostiles, eso hacía que los hombres y mujeres de aquel entonces tuvieran que recurrir a otro método de defensa, y el método de defensa era contestar agresión con agresión. (2014, entrevista personal)

Pese a la hostilidad que encontraron en la ciudad, los afrodescendientes, afectados por el empobrecimiento de la crisis agraria, continuaron llegando a la urbe. Con la segunda ola de migrantes rurales en los años 70, la población afro se diversificó, ya no eran solo negros provenientes del valle del Chota y Mira, sino también de distintos lugares de Esmeraldas que continuaron con el patrón de asentamiento en los barrios periféricos: La Primavera, San Vicente y El Condado al noroccidente, y La Ferroviaria, La Forestal y Chaguarquingo al sur. En los años 80 , con el auge de las tomas de tierras en la ciudad, más migrantes afro se dispersaron en los diferentes barrios periféricos formados algunos por invasiones: Pisulí, La Roldós, Caminos de Libertad, Atucucho, San Carlos, Santa Anita, Comité del Pueblo, La Bota, La Quintana, Carcelén Alto y Bajo, Corazón de Jesús, Carapungo, Luz y Vida, San José de Morán, Solanda y San Luis de Chillogallo (98).

Salvo el caso excepcional del minúsculo barrio África Mía, no hay barrios en Quito que sean habitados única y completamente por afrodescendientes, pues en los treinta barrios periféricos donde están densamente agrupados los asentamientos afros, conviven con otros sectores populares urbanos, mestizos e indígenas, igualmente empobrecidos. El proceso reciente de formación de la mayoría de barrios periféricos de Quito ha sido olvidadizo con el aporte de los afrodescendientes, los barrios les deben su participación en las luchas viviendísticas, especialmente durante las tomas de tierras que permitieron la presión y negociación de terrenos. Digo olvidadizo con los afros porque fueron utilizados como fuerzas de choque, en los momentos álgidos de las invasiones y posesiones hasta cuando se consiguieron los terrenos, luego en 
el reparto de lotes no fueron considerados, como lo asevera Juan Carlos Ocles, citado en Vera (2015):

generalmente todas las invasiones en la ciudad de Quito se han hecho con la gente afro, pero el proceso de adjudicación de los lotes después ya no se ha dado a los afros, sino a los mestizos, a cualquiera, siempre se ha utilizado al pueblo afro pero a la larga quienes tenían posesión de los terrenos era otra gente. Si cogemos todo el noroccidente es historia de invasión y los primeros fueron afros, si cogemos toda la parte del Comité del Pueblo, La Bota, Vencedores o Luchadores de Alfaro son también invasiones afros, y si tú haces ahorita un censo, descubres que quienes están posesionados de los terrenos no son los afros, y hacen que salgan de su posesión [...], cualquier mecanismo utilizaban para sacarles (252).

El estigma de peligrosidad de los negros fue manipulado por los traficantes de tierras y las dirigencias barriales, especialmente en las primeras fases de la formación de los barrios periféricos, y representa otra forma de segregación racial dentro de la marginalidad urbana. Los afros que lograron posesionarse en los lotes durante las invasiones estuvieron más expuestos a las sobreventas ilegales de sus lotes y amenazados constantemente con desalojos, por lo que edificar prontamente una vivienda era la condición para asentarse en el lugar y empezar con el dramático camino de acceso a infraestructura, servicios, equipamiento y en algún momento la regularización del asentamiento para la obtención de las escrituras individuales, pero lo más importante, señalado por Rocío Vera (2015), era crear "las territorialidades" que les permitieran vivir con dignidad. En el camino emprendido, el rol de las mujeres y las redes de solidaridad familiares fue decisivo, permitiéndoles ubicarse en el barrio y asentarse en la ciudad, "las mujeres fueron las que movilizaron a las familias para participar en los procesos de invasión, incluso cuando implicaban arriesgar la vida" (253).

Desde que arribó a la capital, el mayor elemento de hostigamiento y exclusión que el pueblo afro debió enfrentar fue el estigma de peligrosidad y delincuencia ejercido en todos los planos de la vida individual y colectiva. En los pocos estudios sobre los afro quiteños (De la Torre 2003, Antón 2007, Ocles 2012, Delgado 2013, Ramos 2014 y Vera 2015), 
son coincidentes los testimonios acerca del cotidiano y doloroso atropello que han sido víctimas las mujeres y hombres afrodescendientes, ejercidos por varios tipos de agresores y agentes del orden. Responder al estigma delincuencial de los afros en Quito fue uno de los factores que motivaron a su organización, reflexiona Juan Carlos Ocles:

en rechazo al asesinato de Mireya Congo el 6 de diciembre de 1996, que sucedió en la Quito Sur. Este hecho fue realmente el que logró levantar y llamar la atención del pueblo afro para que se organice. Tomando en cuenta que ese año 96 fue súper fatídico para la población afro, porque hubo cualquier cantidad de asesinatos y linchamientos por parte de miembros de la Policía Nacional a nombre de la sociedad, supuestamente porque se trataba de "delincuentes". (2014, entrevista personal)

En el proceso organizativo del pueblo afro en Quito, se distinguen tres momentos diferenciados: el inicio, con la creación de las primeras organizaciones urbanas afro; luego, un lapso de efervescencia de las movilizaciones afro con la formación de las OSG, y posteriormente la incorporación de las demandas en el gobierno local.

Es un ciclo organizativo en el que cada momento se solapa con el siguiente, en una secuencia ascendente de demandas y reivindicaciones, junto con el incremento organizativo en un comienzo, pero propenso luego a su disgregación. El breve ciclo responde a su propia dinamia de activación sociocultural, pero en la dimensión espacial se enmarca en la tendencia general de auge y dispersión del movimiento barrial quiteño, con la diferencia de que la demanda de revitalización étnica del pueblo afro le confiere un sentido singular a la presión colectiva.

El primer momento fue el despegue organizativo de los afroquiteños, al comienzo desde una plataforma ideológica y luego en los barrios periféricos, el que empezó a fines de los años 70 y se extendió hasta comienzos de los años 90. Influenciados por las ideas y luchas internacionales de los negros en Estados Unidos y Colombia, y luego del primer Congreso de la Cultura Negra en América, con el apoyo de la Fundación Interamericana, se creó el Centro de Estudios Afroecuatoriano (CEA) en Quito y Guayaquil, integrado por estudiantes afrodescendientes en la ciudad preocupados por su identidad (Vera 2015, 180). 
El CEA, animado por Juan García, desde entonces "el guardián de la tradición y la memoria", empezó un largo camino de recuperación de la memoria oral de los negros del Chota y Esmeraldas, traducida en una amplia difusión editorial con los Cuadernos Afroecuatorianos, bajo el principio ideológico de que el conocimiento comunitario está en la base de la identidad afro (181). El minucioso trabajo de recopilación y reflexión de las tradiciones y cultura del pueblo afro emprendido por Juan García, más allá de la experiencia del CEA, ha sido uno de los cimientos del posterior camino organizativo y de revitalización cultural del pueblo afro.

Tras varios años de acción el CEA se desintegró y muchos de sus integrantes se reconstituyeron en las comunidades eclesiales que empezaban a conformar los misioneros combonianos. Un aliado estratégico del proceso organizativo de los afrodescendientes ha sido y es la Congregación de los Misioneros Combonianos del Corazón de Jesús, que llegaron al país en 1955 con el mandato papal de evangelizar a la población afro. Luego de casi tres décadas de trabajo pastoral en Esmeraldas, con una postura progresista ganada en el trabajo pastoral, en el debate regional de las reuniones del Consejo Episcopal Latinoamericano de Medellín y Puebla, y con los aprendizajes de las primeras reuniones latinoamericanas de intercambio de experiencias de los agentes de pastoral afro, empezó el trabajo pastoral en los barrios periféricos de Quito.

Los combonianos influyeron en la Conferencia Episcopal Ecuatoriana para la creación del Departamento de Pastoral Afroamericana, con el propósito de formar comunidades eclesiales "con rostro propio y tomando en cuenta los muchos valores evangélicos presentes en nuestra cultura y buscando la unidad el pueblo negro" (De la Torre 2002, 114).

El trabajo organizativo estaba inmerso en el acompañamiento evangelizador al pueblo afro, con lo que sacerdotes y monjas combonianos educaban agentes de pastoral, enlistando a catequistas, estudiantes, jóvenes y en general hombres y mujeres con potencial de liderazgo para la promoción socioorganizativa y la formación de CEB del pueblo afroquiteño.

En respaldo a la labor educativa y de capacitación, que combinaba el aprendizaje de la historia y cultura del pueblo afro con los estudios teo- 
lógicos y pastorales, se formó el Instituto Nacional de Pastoral Afroamericana Monseñor Enrique Bartolucci, desde el que impartían cursos educativos en modalidad a distancia. Asimismo, formaron el Centro Cultural Afroecuatoriano de Quito especializado en la investigación cultural, con el tiempo acumuló y puso a disposición una nutrida biblioteca y centro de documentación especializados en el pueblo afro (33).

La estrategia institucional de la pastoral comboniana se mostraba potente y logró valiosos resultados. Encajaba la formación de organizaciones y comunidades de base en los barrios periféricos, con la educación y capacitación sobre temas formulados desde la perspectiva del pueblo afro, junto con una acción evangelizadora con una teología de la dignidad del negro. Fruto de esta estrategia se creó la mayoría de organizaciones de base en los barrios con asentamientos afro, y se educaron varias promociones de jóvenes negros, hombres y mujeres comprometidos en la causa de la dignidad del pueblo afro, muchos de los cuales liderarían las nuevas organizaciones y más tarde se desempeñarían en el campo de la política nacional.

Con las primeras organizaciones creadas en Guayaquil, Esmeraldas y Quito fundaron, en 1983, el Movimiento Afro Ecuatoriano Conciencia (MAEC), enfocado en el cuestionamiento a la estructura racista de la sociedad ecuatoriana, que tenía como propósito organizar a los grupos afro en los distintos barrios de la ciudad y del país. El MAEC problematizaba la realidad de marginalidad social, económica, cultural, política y religiosa del pueblo afro en las zonas urbanas y rurales, reflexionando sobre las raíces afroamericanas y sus contribuciones étnicas a la cultura nacional. El MAEC se dedicó a la formación de organizaciones en los barrios periféricos y populares con asentamientos de población afro, conforme lo reseña Renán Tadeo en su historia de las organizaciones afroquiteñas, citada por Carlos de la Torre:

En Atucucho se forma la Asociación Nelson Mandela; en Santa Anita catorce madres solteras forman África Mía; en La Roldós se conformó la Afro Martín Luther King dirigida por la señora Graciela Calderón; en Carcelén Franqueza Negra; en el barrio Corazón de Jesús la asociación África Son y Tambor; en Carapungo las organizaciones Raíces Africa- 
nas, Martina Carrillo, Malcom X, Hijas de Daniel Camboni y Canela; en la Ferroviaria Alta Despierta Negro. (119)

El movimiento se empeñó en recuperar y escribir la historia de los negros, recolectando datos y hechos en una narrativa desde los propios protagonistas, que a la vez servía de estímulo para elevar la autoestima del pueblo afro. El conocimiento de la historia y la recuperación de la cultura afro, conforme a la estrategia pastoral, se usaba en el trabajo organizativo barrial, por lo que las organizaciones se formaron en torno a referentes culturales de la identidad afrodescendiente.

El medio de difusión del activismo eclesial barrial fue el Boletín Palenque (Vera 2015, 183-5). Se trató de un período fundacional de casi dos décadas en el que se crearon las pioneras organizaciones de base del pueblo afroecuatoriano en los barrios periféricos de la ciudad, formándose veinticuatro de las veintisiete organizaciones en los diecisiete barrios capitalinos que tenían asentamientos afros.

El segundo momento corresponde al breve lapso de efervescencia de las marchas y plantones en Quito contra la discriminación afro, acaecidos durante los años 90 y comienzos de la década de 2000, y que se activó con la formación de las OSG en las seis provincias del país con población afro, las que confluyeron en la creación de la Confederación Nacional Afroecuatoriana en noviembre de 2001. Cuatro años antes, en junio de 1997, en el sexto encuentro de familias negras nació la Federación de Organizaciones y Grupos Negros de Pichincha (FOGNEP), integrada por las organizaciones territoriales de base y los diversos grupos afros de los barrios periféricos (2015), como un espacio de agregación de sus demandas en la provincia de Pichincha, en la práctica condensadas en la capital.

Para emprender sus actividades la federación se constituyó en cuatro comisiones. La comisión política se encargó del trabajo de incidencia en el nivel local, ante el municipio metropolitano; la de cultura se responsabilizó de tratar sus temas a nivel nacional; la de derechos humanos continuó atendiendo las denuncias de la cotidiana agresión al pueblo afro en la ciudad; la de educación se encargó de incidir en el 
sistema educativo público para incorporar el enfoque de etnoeducación en la estructura curricular (Ocles 2014).

La FOGNEP se propuso tres acciones inmediatas para consolidar su estructura organizativa. Uno, cohesionar a las organizaciones de base en la lucha contra la discriminación, el racismo y avanzar en la igualdad de derechos y oportunidades. Dos, influir en la legislación nacional para que se reconozca a los héroes negros en la historia nacional, la inclusión de la cultura afro en el currículo educativo y la declaración del Día Internacional del Negro en Ecuador. Y tres, junto con la promoción de los derechos del pueblo afro en el Plan Nacional de Derechos Humanos, por entonces impulsado por el Ministerio de Relaciones Exteriores, se propuso influir para el reconocimiento del pueblo afroecuatoriano en la Constitución de 1998 (2014).

La FOGNEP empezó con su "estrategia de representación" liderando la marcha denominada "Por un futuro negro, digno y bonito" en 1997, en contra de la discriminación y el racismo, demandando que se pare la ola de asesinatos que impunemente se habían perpetrado contra hombres y mujeres negros en la ciudad, y se sancione a sus responsables. Exigiendo justicia y respeto, la marcha denunció el "derecho a la vida del pueblo negro", recuerda Ocles, y fue la primera expresión colectiva del pueblo afroquiteño en el espacio público capitalino.

Si bien no fue un evento masivo, afirmó que los negros existían en la ciudad como un colectivo organizado que emplazaba el ejercicio de la ciudadanía y anunciaba que habría nuevos eventos para continuar con el camino iniciado de su reconocimiento y defensa cultural. Poco tiempo después, la FOGNEP lideraba otra marcha de las organizaciones negras hacia el Congreso Nacional, exigiendo una ley especial que institucionalizara el Día Nacional del Pueblo Negro y elevara a Alonso de Illescas a héroe nacional (Vera 2015).

El 21 de marzo de 2002 la FOGNEP protagonizó una tercera Marcha por la Dignidad del Pueblo Negro, nuevamente en reacción a la continua serie de eventos de "brutalidad policial" contra la gente negra ocurridos en los primeros meses de dicho año (De la Torre 2002, 34-5). Asimismo, lideró varios plantones delante de las entidades públicas, exigiendo la aplicación del recurso de hábeas corpus para sacar de la pri- 
sión a las numerosas personas afro detenidas arbitrariamente, acciones que revelaban la perspectiva democrática adoptada por la federación de exigir el cumplimiento de los derechos ciudadanos, al mismo tiempo que visibilizaba la situación de los negros y buscaba aliados entre los "grupos que luchan por los derechos humanos".

Otras organizaciones del pueblo afro empezaron a innovar sus forma de protesta, para protegerse durante las incursiones callejeras, como lo hizo la organización Afro 29 que otorgaba "un carnet de identificación de sus miembros mediante la Asamblea Permanente de los Derechos Humanos para que lo puedan presentar a la policía cuando sean detenidos injustamente" (97). Junto con la creación de la FOGNEP, algunas de las mujeres negras que se había educado en los grupos y comunidades eclesiales negras formaron en 1997 el Movimiento de Mujeres Negras (MOMUNE), con el propósito de enfrentar la discriminación a las mujeres negras en la ciudad. Realizaron en 1998 el Primer Encuentro de Mujeres Negras, y crearon la Casa Yemanyá como espacio de diálogo y gestión de proyectos de capacitación, cursos de educación compensatoria, además de varios talleres de salud y biodanza, en los que se combinaban las "relaciones de representación con las políticas de representación".

Participaron en el Primer Encuentro Nacional de Mujeres Negras en 1999, en el que elaboraron la Agenda Política de las Mujeres Negras del Ecuador, y en varios encuentros de mujeres negras, hasta que el proceso organizativo desembocó, en el año 2000, en la formación de la Coordinación Nacional de Mujeres Negras del Ecuador (CONAMUNE) (Vera 2015, 196-203).

Las mujeres negras quiteñas también protagonizaron varios plantones frente a las instituciones públicas en distintos sitios de la ciudad, intervinieron en foros académicos de análisis y en eventos políticos de denuncia sobre su discriminación racial y estigmatización sexual. En este sentido, fue una victoria el plantón organizado por las mujeres negras de la ciudad y apoyado por los grupos feministas en abril de 2000, el que consiguió retirar una publicidad que denigraba el cuerpo de la mujer negra y dio lugar a la confluencia de alianzas entre grupos feministas blanco-mestizos y organizaciones de mujeres negras (De la Torre 
2002, 97). En adelante, fue frecuente la convergencia programática de organizaciones de mujeres negras y grupos feministas en la ciudad.

Las mujeres negras asumieron su lucha cotidiana contra el racismo y la discriminación, con la ocupación de espacios urbanos para el despliegue de prácticas ciudadanas, como lo señaló la joven dirigente de las mujeres negras Alexandra Ocles, al explicar que la lucha buscaba "liberar territorios". "Donde nosotras estemos no permitiremos la discriminación" (96). Vista por unos como "educar al discriminador", y por otros como el esfuerzo de concienciar sobre la diferencia y la exclusión al interior de los asentamientos afros, en la convivencia diaria con los demás ciudadanos.

La supresión de la inferioridad de los afrodescendientes también es, como lo diría Juan García: "casa adentro", en el propio espacio urbano de la cultura afro, donde también es válido el metafórico principio literario de la sabiduría ancestral de "caminar y andar, andar y caminar" (Walsh 2017, 135-6), asegurándose de que la comunidad negra esté “andando al encuentro con su bienestar", y no confundida en el caminar del individualismo de las ilusiones modernizantes citadinas.

El tercer momento en el camino organizativo de los negros urbanos corresponde a lo que considero la incorporación de las demandas de los afroquiteños en el municipio metropolitano, y la desactivación de las marchas y plantones de sus organizaciones. Fue un lapso en que se dieron pasos sustantivos en dirección a la cohesión de la identidad afroquiteña, apoyados con la acción municipal, y, al mismo tiempo, vieron el declive de la capacidad de presión colectiva con la dispersión de sus organizaciones.

Las relaciones de los afroquiteños con el cabildo quiteño fueron polémicas desde el inicio del proceso metropolitano, no se plantearon la lucha barrial por la segregación urbana de los asentamientos negros, sino tres demandas prácticas ligadas a su supervivencia: el acceso a empleo, a condiciones de vivienda y a servicios de salud. Era una agenda mínima.

A fines de los años 90, en el segundo período administrativo del alcalde Jamil Mahuad, en los días previos a su renuncia para postularse a la presidencia del país, los afroquiteños plantearon su propuesta, pero la respuesta municipal fue que el gobierno estaba "abierto a todos los gru- 
pos y pueblos, para todas las personas sin diferencia alguna", comenta Ocles. Sin embargo, en la práctica se evidenció que no había tal apertura; al contrario: justo por esos días se produjo un accidente de tránsito de un vehículo municipal en el que falleció una persona afrodescendiente, el indolente desenlace ratificó que persistía el menosprecio del gobierno local a los negros (2014).

Durante el período de gobierno municipal de la democracia cristiana, el pueblo afroquiteño, en palabras de su representante, "prácticamente pasó desapercibido", a lo sumo hubo cierto involucramiento en los eventos culturales durante el denominado Agosto Mes de las Artes, en el que se consideraba a los negros bajo el cliché de su alegría y sonoridad musical. "Los negros nos hemos convertido en los payasos de las fiestas de los blancos", señala irónicamente Ocles, y no le falta razón, puesto que la actitud municipal se limitaba a convocar a los grupos afro con propósitos alegóricos y festivos, generalmente en condiciones precarias que solo cubrían el transporte y los refrigerios, los demás costos de las presentaciones corrían de cuenta de los participantes (2014). Las expresiones culturales del pueblo afro, reducidas al baile y a la sonoridad musical, no eran valoradas; al contrario, servían para reproducir, en el plano artístico musical, el estigma de la identidad rural de los negros como bullangueros y festivos, cuestión que el líder afro refuta:

la cultura del pueblo afro no solo se refleja en bailar, sino en todo lo que entendemos por cultura, es decir, como el ciclo de vida de una persona y un pueblo, en ese ciclo de vida tenemos varias acepciones que podemos trabajar y no solamente el baile [...]. Lo que he dicho en un artículo que escribí, es que utilicemos nuestro baile, nuestra danza, para hacer conciencia en la sociedad y expresar todo lo que somos, y que no solo somos baile. (Entrevista personal)

A pesar de la utilización simbólica de los negros como expresión de la diversidad cultural del distrito metropolitano, los afroquiteños volvieron a presentar la propuesta al alcalde encargado, sin ningún resultado, por lo que se replegaron a sus organizaciones en espera de la asunción de las próximas autoridades seccionales, reflexionando sobre su propuesta que, en esencia, buscaba soluciones prácticas a la compleja 
situación de marginación de los afrodescendientes en la ciudad, como lo explica Ocles:

Frente a eso planteamos una propuesta para hacer un trabajo más programático, que iba a afectar a toda la población afro: La participación del pueblo afro en todas las instancias municipales, y que seamos parte de la planificación, del diseño de las acciones que el municipio tiene para la población; en tres temas: empleo, vivienda y salud, que en esos tres temas la población afro logre acceder directamente, que no haya toda esa serie de restricciones, porque, por ejemplo, el pueblo afro iba a buscar trabajo y no conseguía, iba a buscar vivienda y no conseguía o estaba viviendo y comenzaban a quitarle los servicios básicos. Ir generando unos mecanismos para contrarrestar eso, esa era la propuesta. (Entrevista personal)

El nuevo gobierno municipal del partido socialdemócrata, presidido por Paco Moncayo, fue más abierto con los afroquiteños, pues en agosto de 2000, un día después de que asumió la alcaldía, la FOGNEP y el MOMUNE presentaron una propuesta por escrito al municipio y solicitaron audiencia con el alcalde, a los pocos días se reunieron y le expusieron la misma propuesta que habían presentado a las anteriores autoridades. El alcalde la aceptó e invitó a involucrarse en el diseño de la institucionalidad adecuada, conjuntamente con el pueblo indígena de la ciudad, pero surgieron desacuerdos entre las organizaciones de afros e indígenas acerca de la estructura, sus integrantes y los roles; luego de varios debates acordaron que sería una sola dirección con dos coordinaciones: una para el pueblo afro y otra para el pueblo indígena, cada una integrada por un coordinador, un asistente técnico y un promotor. Mientras los indígenas insistían en que la dirección sea presidida por un indígena, los afro coincidieron con la candidata propuesta por el alcalde (2014), con lo que se dio paso a la creación de la nueva dependencia municipal.

Las organizaciones afroquiteñas habían negociado con el alcalde metropolitano su propuesta. En 2001 se creó la Unidad de Desarrollo del Pueblo Afroecuatoriano, adscrita a la Dirección Metropolitana de Desarrollo Social y Económico con la misión de: “disminuir los niveles de pobreza, fortalecer la autogestión, y lograr la integración democrática del pueblo afroquiteño, incorporando su propia visión de desarrollo y 
potenciando sus actuales recursos, su capital humano y social, mediante la construcción y puesta en marcha de políticas, planes y proyectos de desarrollo sustentable con identidad" (99).

\section{Corporativismo afro: Cultura en lugar de movilización}

Con la creación de la nueva dependencia municipal, se inauguró una modalidad de cogestión pública comunitaria entre el municipio metropolitano y las organizaciones de afrodescendientes, orientada a mejorar sus condiciones de vida, que consideraba, de partida, a los afros como parte de la ciudadanía capitalina. Operativamente, la cogestión implicaba que el municipio colocaba los recursos y delimitaba acciones dentro de su programación estratégica, mientras las organizaciones afro proveían del personal y los lineamientos socioculturales para las intervenciones; se estableció un acuerdo por el cual a los integrantes de la unidad, en representación del pueblo afro y nombrados por la FOGNEP en asamblea general anual, mediante evaluación y por pedido escrito, el municipio les renovaba sus contratos laborales (98).

En adelante, el municipio emprendió un conjunto de acciones y políticas a favor del pueblo afroquiteño, en una apertura de corte liberal del gobierno local a las culturas minoritarias, visibilizando su participación en el desarrollo metropolitano de la ciudad. Las acciones de cogestión se implementaron en cuatro ámbitos: fortalecimiento organizativo, políticas inclusivas, revitalización cultural y generación de empleo, las que están recogidas en el análisis de Ocles (100-3) sobre la incidencia política del pueblo afro, y que reseño a continuación.

En cuanto al fortalecimiento organizativo, aunque no es una función municipal, se ejecutaron actividades enfocadas a contribuir a la unión del pueblo negro, empezando con incorporar la unidad en el orgánico funcional del municipio para el período 2001-2009. Se realizó el primer "apalencamiento" del pueblo afro para debatir su agenda, se establecieron varios acuerdos entre los grupos afro y el municipio, se impulsó el palenque de la tercera edad, un convenio con el Patronato San José en favor de la niñez afroecuatoriana y se realizó el Congreso Metro- 
politano de la Niñez Afroquiteña. Se promovió la inclusión de los afros en los consejos metropolitanos de Salud, Equidad, Niñez y Adolescencia.

Se formaron nuevas organizaciones afros en los barrios: Malcom X en Santa Bárbara, Carameleros Jimmy Rosero Mercado en La Marín, Unidos por Una Gran Amistad Afroecuatoriana en la segunda etapa de La Roldós; se impulsó la creación de la Casa de la Equidad para los grupos negros y sede de la FOGNEP, así como la Escuela Permanente de Liderazgo Afroecuatoriano Jonatás Sáenz para jóvenes y dirigentes (101).

En el ámbito de las políticas inclusivas el municipio capitalino promovió iniciativas contra la discriminación, como integrar la Coalición Latinoamericana y Caribeña Contra el Racismo, realizó el diagnóstico social, económico y cultural de la ciudadanía afroquiteña y formuló el Plan Metropolitano Estratégico Integral del Pueblo Afrodescendiente de Quito 2007-2015.

En 2007 se aprobó la Ordenanza Metropolitana 0216 para la Inclusión Social con Enfoque Étnico Cultural del Pueblo Afro, dentro de la que se creó el Consejo Social Metropolitano para la Eliminación de la Discriminación Racial (COSMEDIR), encargado del seguimiento y gestión de las denuncias de discriminación; se estableció un régimen de sanciones administrativas y reparatorias por actos de discriminación y se hizo el reglamento para la implementación de la Ordenanza 0216. Se impulsó el Foro Regional Internacional de Organismos Municipales de Equidad Racial en 2008, y en el mismo año se realizó la Declaración de Quito para la Eliminación de la Discriminación Racial y la Generación de Igualdad de Oportunidades (102).

En cuanto a la revitalización cultural del pueblo afroquiteño, se incorporó la visión del pueblo afro en la Cátedra de la Ciudad 20012003, se creó la condecoración municipal Jonatás Sáenz para la Inclusión Social, se denominó una calle con su nombre, luego otras tres calles con nombres de personajes afro y se publicaron varios cuadernos de etnoeducación. En 2010 se realizó el Foro Nacional Ciudades Libres de Racismo, Discriminación y Xenofobia. Con la resolución C-236 de 15 marzo de 2012, se reconoció el esfuerzo del pueblo afro, y el municipio, a nombre del pueblo quiteño, pidió “perdón histórico al Pueblo 
Afrodescendiente" (102) y exhortó a la sociedad a trabajar a favor del desarrollo de la población afroecuatoriana.

En el mismo año se declaró Patrimonio Tangible e Intangible del DMQ a la Cultura Afroecuatoriana, se designó el primer domingo de octubre de cada año para que las instituciones metropolitanas celebren el Día Nacional de Pueblo Afroecuatoriano y se institucionalizó el 21 de marzo de cada año como el Día Metropolitano para la Eliminación de la Discriminación Racial. Igualmente, se estableció el Decenio de las y los Afrodescendientes en el DMQ, entre el 21 de marzo de 2012 y el 21 de marzo de 2022 (103), como un período de fortalecimiento de las políticas públicas a favor de los afrodescendientes.

En cuanto a la generación de empleo, se creó el Grupo de Apoyo de Empleados y Funcionarios Afros del DMQ para la ejecución de la Ordenanza 0216, y se estableció un sistema de cupos promocionales para la población afroecuatoriana en la administración municipal. Se fomentó el ingreso a las filas policiales metropolitanas de más de doscientos afroecuatorianos, hombres y mujeres, se capacitó a quinientas personas afroecuatorianas en emprendimientos de economía social y solidaria, y se aseguró la cuota laboral del $10 \%$ de los agentes metropolitanos de tránsito para afroecuatorianos (103).

Como se advierte, las demandas de los afroquiteños se tradujeron en un conjunto de acciones municipales en el que más de la mitad eran iniciativas "cívicas", del tipo "políticas de discriminación positiva" (Kymlicka 2004), dirigidas a combatir la exclusión racial, sin discutir sus causas estructurales. Detrás hay una postura liberal de acciones de cogestión municipal emprendidas, que es consistente con el proceso de modernidad metropolitano, en tanto se asume que el municipio capitalino, como parte del Estado nacional, es corresponsable del reconocimiento y la reproducción de los grupos culturales minoritarios en la ciudad, deviniendo ineludible la politización de las identidades culturales. Las aspiraciones de reconocimiento de los derechos ciudadanos de los afroquiteños no se eximen de los valores modernos de libertad y autonomía que refuerzan el individualismo desde la identidad cultural, 
en la medida en que les confiere el escenario primordial para el ejercicio de sus derechos y autonomía.

Dada la extrema exclusión de los afros en la urbe, haber optado por la gestión de sus demandas en el municipio les posibilitó avanzar en la cohesión del pueblo afroquiteño como un colectivo con exigencias singulares de identidad, y con los mismos derechos ciudadanos que el resto de habitantes de la ciudad. Permitió crear un marco de reconocimiento público para el fortalecimiento de la cultura afroquiteña, en el que, de alguna manera, compelieron al municipio metropolitano y al Estado nacional a asumirse como parte de un Estado social de derechos que promueve condiciones de bienestar e inclusión ciudadanas.

La relación de las organizaciones afroquiteñas con el municipio metropolitano también revela su carácter corporativo, en el sentido de que el municipio se convirtió, por voluntad de sus protagonistas, en el marco referencial de las luchas afroquiteñas. Reconociendo a los actores y voceros del pueblo afro, el municipio negoció su agenda de reivindicaciones y demandas, dosificando la concesión de recursos, bienes y servicios públicos a las organizaciones y promoviendo, en algún grado, la movilidad social de los líderes al incorporarles en las dependencias municipales (De la Torre 2002, 83), o corresponsabilizándoles de su gestión en los barrios periféricos con asentamientos de afrodescendientes.

Las acciones emprendidas estaban adscritas operativamente al radio de influencia de las dependencias municipales, especialmente educativas, de las que se esperarían impactos positivos en la sociedad capitalina. Representan el esfuerzo de las organizaciones afro por posicionar en la esfera del interés público local sus condiciones de convivencia urbana que habían sido negadas desde su arribo a la ciudad, por la naturalizada ruralidad del imaginario blanco-mestizo citadino. Lo hicieron desde la perspectiva de reconocimiento y exigibilidad de los derechos ciudadanos y colectivos del pueblo afroquiteño, con iniciativas culturales que buscan ser permanentes mediante la institucionalización de determinados elementos didácticos de la cultura afro que, al tiempo que educan a la población, evidencian su contribución al enriquecimiento de la identidad metropolitana de la ciudad. 
En la búsqueda legítima de empleo en el sector público por parte de los afroquiteños, algunos dirigentes cayeron en la cooptación institucional explicable porque no se trata de un sector marginal atraído por la retórica populista que engloba lo afro dentro del pueblo, sino de una perspectiva de ciudadanía inclusiva ante un sector secularmente discriminado, incluido en el ámbito público local por la predisposición edilicia a la participación ciudadana (Torres 2008, 75-6). El estilo inclusivo del burgomaestre atrajo la atención del pueblo afroquiteño.

Las organizaciones afroquiteñas no fueron ajenas al repliegue de las luchas de los sectores populares capitalinos, marcadas en la última etapa por la dispersión de las organizaciones que, aunque iban en aumento, tendían al fraccionamiento de sus demandas. Al igual que lo ocurrido con el movimiento barrial, las organizaciones afroquiteñas crecieron en número pero declinaron en su capacidad de presión y movilización. El corporativismo de las relaciones de las organizaciones del pueblo afroquiteño con el gobierno metropolitano tuvo un costo ineludible: las acciones municipales progresivamente sustituyeron las iniciativas de las organizaciones afro, especialmente a las de segundo grado que vieron declinar sus capacidades de convocatoria social y negociación política.

En el pueblo afro la tendencia de decline organizativo es más pronunciada, debido al corporativismo extendido de las relaciones con el Estado entre todas las federaciones provinciales y su organización nacional, que anclaron el avance de sus reivindicaciones a la institucionalidad estatal. Sucedió con el Gobierno de Abdalá Bucaram en torno al fallido Ministerio Étnico Cultural, y en el Gobierno interino de Fabián Alarcón con la creación de la Corporación de Desarrollo Afroecuatoriano (CODAE). Mientras en el Gobierno de Jamil Mahuad se mantuvieron congeladas las relaciones desde cuando ejerció la alcaldía, en el Gobierno de Gustavo Noboa emprendieron el fortalecimiento de la CODAE, y con Lucio Gutiérrez, ilusionados en la consolidación de la CODAE, en cambio, presenciaron su desmoronamiento, ante lo cual las organizaciones afroquiteñas decidieron continuar en las relaciones con el municipio capitalino (Ocles 2014). 
Las organizaciones afroquiteñas atravesaban por una paradójica condición de logros públicos, a costa de la desmovilización de sus organizaciones. Experimentaban las tensiones entre el corporativismo de las relaciones estatales y municipales, y el debilitamiento de las organizaciones federativas, en un contexto nacional de prolongada crisis política del sistema de representación que, en la ciudad de Quito, activó las multitudinarias movilizaciones de las clases medias y altas que contribuyeron a los derrocamientos presidenciales, eventos en los que los afroquiteños desmovilizados también se mostraron expectantes.

Así, en el tercer momento del camino emprendido, si bien las demandas de identidad cultural del pueblo afroquiteño que interpelaban a la ciudadanía capitalina contaban con el apoyo del municipio, sus organizaciones, en cambio, se habían desmovilizado. Frente al avance de la modernidad metropolitana de la ciudad, las reivindicaciones de reconocimiento e inclusión afro formaban parte de la tendencia generalizada de fragmentación de intereses en que se encontraban todas las organizaciones populares de la capital, en ausencia de instancias federativas de agregación de intereses que posibilitan la acción colectiva, como se evidenció claramente a fines de los años 2000 y que se prolongará en la siguiente década. Las organizaciones del pueblo afroquiteño eran parte de la tendencia generalizada de decline de las luchas populares urbanas, como lo explica Juan Carlos Ocles:

Hay un proceso de desmovilización total de todas las organizaciones, de toda la expresión social del contexto nacional, sin excepción alguna. Por ahí, de vez en cuando, el movimiento indígena hace algo, pero no hay una articulación como tal. Y le digo una sola cosa: resulta que todos los movimientos sociales, sin excluir a nadie, buscábamos que nuestras propuestas consten en algo y que nuestras propuestas vayan aplicándose, y cuando surgió la Asamblea Constituyente, ahí nos metimos de cabeza, nos metidos todos [...] y logramos que recogiera varios puntos de los movimientos sociales: si buscamos el movimiento de mujeres tiene ahí sus artículos, las luchas de los jóvenes también están recogidas en la Constitución, las de los adultos mayores; es decir, es una Constitución sumamente abarcativa, que habla de acciones afirmativas, donde se recoge incluso el derecho a la naturaleza. En otras palabras, vemos que 
esta Constitución recoge todo el discurso de los movimientos sociales. (Entrevista personal)

En la explicación de la desmovilización de las organizaciones afroquiteñas, desde la perspectiva de sus líderes, hay tres elementos concurrentes: la fuerza colectiva enfocada en el reconocimiento de derechos pero no en su exigibilidad, las condiciones materiales de inserción individual en la ciudad que limitan la movilización y cierta confusión en la narrativa identitaria de la afrodescendencia.

El esfuerzo volcado más en el reconocimiento y menos en la exigibilidad forma parte de un estilo de gestión de las organizaciones sociales de concentrarse en el diagnóstico de los problemas y en el planteamiento de alternativas, sin avanzar en las destrezas para la implementación de las soluciones colectivas, más aún cuando están referidas a las políticas públicas locales. La movilización de las organizaciones tiende a la denuncia y al reconocimiento de derechos, antes que a la acción pública que los implemente.

Es un viejo dilema de la participación comunitaria cuando se encuentra en escenarios de participación ciudadana, en los que no son suficientes las fuerzas de las organizaciones de base, sino que se requieren de alianzas mayores y diversas con otros grupos o movimientos sociales, en torno a metas compartidas que modifiquen las condiciones de vida. Implica el desafío de la participación ciudadana más allá de los conocidos consensos en la planificación, de la transparencia y rendición de cuentas de las autoridades locales.

Supone nuevas maneras de formular y ejecutar políticas públicas desde y para los ciudadanos como "agentes activos" en la enunciación de intereses colectivos y en calidad de "agentes creadores de valor" en la gestión de resultados públicos (Pastor 2013, 196). Presupone una ciudadanía portadora de recursos sociales (capacidades, prácticas, destrezas, etc.) que, pertinentemente relacionados con los recursos públicos (infraestructura, financieros, técnicos, humanos, etc.), pueden ser decisivos para resolver las necesidades sociales y "adecuar las decisiones adoptadas a la realidad" (196). 
Es el reto de la participación en la acción pública durante la formulación, gestión y evaluación de políticas de prestación de bienes y servicios públicos y en la retroalimentación de las políticas desde la experiencia social. En cierto sentido, es una frontera de la participación ciudadana cuando la agenda todavía es sistémica: aunque las demandas estén reconocidas en las normas, su implementación depende de la presión social, revirtiéndose circularmente sobre las propias organizaciones que se movilizan solo cuando tienen intereses que les compelen a la acción colectiva.

Cómo llevar a la práctica las reivindicaciones del pueblo afro, cuando ya están reconocidas en la legislación pública, es el dilema de las organizaciones afroquiteñas, "marchar para exigir algo que ya está reconocido", no tiene mayor sentido reflexiona Ocles, pensando que en el Gobierno nacional las movilizaciones hubiesen significado enfrentar al pueblo afro contra sí mismo:

¿Marchar para exigir qué? Además no podíamos porque estábamos protestando contra nosotros mismos, porque si tomamos en cuenta el primer gabinete de este período presidencial fue plurinacional e intercultural, el pueblo afro tenía nada más y nada menos que a nuestro mayor representante que era Antonio Preciado y estaba de Ministro de Cultura. ¿Cómo protestábamos contra eso? O sea, habían cosas muy representativas, muy relevantes que realmente nos imposibilitaban actuar. (2014, entrevista personal)

El corporativismo estatal y municipal en el proceso del pueblo afroquiteño implicó la cooptación de la dirigencia y los liderazgos, cuestión que es reconocida por sus dirigentes como parte del camino seguido por las organizaciones. A más de la cooptación, el otro factor de incidencia en la desmovilización de las organizaciones afroquiteñas es la forma de vida individual en la ciudad. Si bien las primeras inserciones urbanas de la gente afro se hicieron mediante las redes familiares y territoriales propias de las migraciones, las continuidades rurales-urbanas y los flujos de comunidad-familia-asentamiento se fueron debilitando y con el paso del tiempo desaparecieron. Se mantienen las continuidades entre el lugar de origen y la ciudad solo en el plano cultural, pues todavía 
hay grupos que regresan al lugar de los ancestros en los momentos festivos, para fortalecerse espiritualmente y continuar con la vida urbana.

El individualismo económico se impuso entre los afro en la ciudad, coartando las posibilidades organizativas, especialmente por las condiciones de pobreza que se agudizaron con la dolarización adoptada por el país en el año 2000, cuando las organizaciones afroquiteñas estaban en el auge de sus movilizaciones.

La dolarización constriñó el tiempo disponible de la gente afro para los asuntos extraeconómicos, ya que la flexibilización laboral y la tercerización ocupacional ampliaron la jornada laboral, profundizándose, como consecuencia, la precarización del empleo. Para Ocles, desde la dolarización, la gente afrodescendiente de la ciudad empezó a "trabajar más por el mismo sueldo, inclusive hasta los fines de semana, eso hizo que la gente ya no pueda estar en las organizaciones", los negros somos urbanos, y al ser urbanos somos dependientes de la relación laboral, de los horarios, debemos cumplir unas instrucciones, señala Ocles:

la población afroecuatoriana, aquí en la parte urbana —alrededor del $71 \%$ de la población afroecuatoriana somos urbanos-, dependemos de un horario, dependemos de un trabajo y el día que no trabajemos nos multan o corremos el riesgo de perder el trabajo, y ya no estamos pensando en la organización, sino que nos hemos vuelto como individualistas; es decir, primero soluciono el problema de mi casa y según eso lo que sobre le doy a la organización, eso es lo que ha pasado después de la dolarización. (Entrevista personal)

El agotamiento de los nexos comunitarios originarios y la propensión a la individualidad económica explicarían también el debilitamiento de las organizaciones afroquiteñas. Pero hay una tercera razón del declive de las movilizaciones de las organizaciones afroquiteñas: se relaciona con las redefiniciones de sentidos de las identidades negras y afrodescendientes, a partir de la etnicidad.

Mientras unos grupos están interesados en la identidad negra y en la negritud como un proyecto político, buscando forjar identidades negras alternativas, o en busca de espacios en la sociedad que valoren la negritud, en los cuales se respete y se los reconozca como negros (De la 
Torre 2002, 107); otros grupos están empeñados en forjar la identidad afro a partir de recuperar la memoria colectiva de las comunidades de origen africano, negadas por las formas tradicionales y culturales de la sociedad mestiza dominante, en condiciones en que la cultura de origen africano es, ante todo, una cultura nacida en la resistencia, explica Juan García (Walsh 2017, 112).

De acuerdo con Carlos de la Torre, quien cita un estudio sobre los negros de un barrio pobre de Quito realizado en los años 90, se argumenta que sería desacertado asumir que la mayoría de afroquiteños se ven a sí mismos mediante identidades que "privilegian su negritud", pues el estudio demuestra que "la mayoría de negros y negras pobres no están muy interesados en su negritud” $(2002,107)$. El debate sobre la negritud y lo afro atraviesa a las organizaciones de afroquiteños, especialmente porque las políticas estatales sobre los grupos étnicos del país han adoptado el enfoque de la afrodescendencia para referirse a los grupos afros, negros y mulatos, manteniendo las distinciones étnicas, como se registra en el Censo 2010 que establece esas posibilidades de autorreferencia cultural.

Juan Carlos Ocles, al analizar en detalle los hitos históricos de conformación de las narrativas de la afrodescendencia y de la negritud, dice que, si bien ambas tienen origen africano, hay diferencias importantes. Lo negro fue utilizado para negar el bagaje cultural africano y naturalizar la animalidad de los negros, de ahí surgió una línea filosófica contestataria de la negritud afirmándose en el color, que avanza como una postura de alteridad epistémica. Mientras que lo afro tiene dos grandes connotaciones: por un lado, recupera todo el acervo histórico y el aporte de las culturas de origen africano en el mundo; por otro, es una terminología que ha sido aceptada políticamente por los Estados. En la conferencia mundial de la afrodescendencia realizada en Chile en el año 2000, uno de los grandes líderes afrodescendiente uruguayo refiriéndose al evento comentó: "entramos como negros y salimos como afrodescendientes" (2014).

Ocles apoya la postura de que lo afro representa una pérdida para el pueblo negro, porque la discriminación no se da en referencia a la con- 
dición afroecuatoriana, sino por ser negro, cuando agreden o insultan a la gente "le dicen negro, no dicen afroecuatoriano tal y cual". La afroecuatorianidad encarna un encantamiento de inclusión que provoca una actitud, entre las organizaciones, de "bajar la guardia", comenta Ocles:

Uno de los elementos fundamentales para que nuestras organizaciones estén débiles, es justamente eso: la utilización de esta nueva terminología, porque la gente no sabe de qué están hablando. Entonces tengo que seguir utilizando la palabra negro aunque sea de enganche, y en el proceso de concienciación en el que se van haciendo las reflexiones, se van asumiendo como afro. Pero uno de los elementos fundamentales fue ese cambio de terminología, si bien es cierto que lo afrodescendiente nos devuelve todo un bagaje cultural, nos hace políticamente aceptables ante el Estado, pero eso es en lo alto, porque abajo seguimos siendo negros para la sociedad y nos siguen discriminando por negros y no por afros. (Entrevista personal)

Sin duda son complejos los debates entre las narrativas de la afrodescendencia y la negritud, aunque ambas enriquecen la diferencia cultural del pueblo afro. Si bien dan lugar a confusiones entre las organizaciones de base, que repercuten en la desmovilización social por las tensiones entre las acciones afirmativas basadas en la narrativa de la afrodescendencia y la persistencia del racismo con el estigma de lo negro, son también consecuencia del corporativismo organizativo. El Estado, al recurrir al enfoque de la afrodescendencia en la implementación de las acciones afirmativas, interpela una forma de organización que le relacione con un segmento de la población, en este caso de afrodescendientes.

Las organizaciones afroquiteñas han asumido un imaginario político por el que, si bien la discriminación está en la sociedad y en la economía, el garante es el Estado, enfocando todo su esfuerzo en buscar el reconocimiento de derechos y la defensa cultural en las esferas nacional y local. Por eso reconocen que sus formas de acción organizativa son distintas a las de otros grupos sociales, para lo afros la movilización no está en su agenda, por lo que no cabe hacer un símil entre las movilizaciones de los afrodescendientes y del movimiento indígena, comenta Ocles, para quien los impulsos y las formas de presión provienen de la cultura: 
la movilización no está dentro de nuestra agenda, porque no creemos en la movilización, creemos más en la propuesta, en el lobby, nosotros entregamos la propuesta, y si una vez que hemos entregado la propuesta necesitamos hacer una movilización, lo hacemos. Pero nuestra movilización es prácticamente cultural, no hacemos una marcha sino que hacemos una toma, es decir, llegamos, nos tomamos el lugar y ahí comenzamos a tocar nuestra marimba, a tocar nuestra bomba, entonces es más cultural y eso no genera rechazo, sino que mucha gente se adhiere. (Entrevista personal)

Aunque reconocen que estas formas culturales de presión de las organizaciones afroquiteñas no tienen efectos mediáticos ni generan opinión pública y son insuficientes para posicionar públicamente las demandas del pueblo afroecuatoriano como parte de los problemas nacionales, consideran que en el campo jurídico han conseguido logros importantes en el reconocimiento de sus derechos y en la defensa cultural.

No obstante, en abril de 2012 más de trescientos afroecuatorianos representantes de dieciocho organizaciones provenientes de varios lugares del país, mayormente de Esmeraldas, "caminaron a Quito y realizaron un plantón en la Plaza Grande, frente al Palacio de Carondelet”, para demandar el acatamiento del Decreto 60, expedido por el presidente de la República en 2009, con el que se buscaba "superar las inequidades, cerrar las brechas sociales y combatir el racismo y la discriminación". Vistiendo una camiseta negra con el lema: "Marcha afroecuatorianos por la dignidad y la vida", evidenciaron la persistencia de las desigualdades y las prácticas de discriminación y racismo, exhortando a la convivencia de "distintos pueblos bajo el precepto de la interculturalidad" (Vera 2015, 195-6).

La marcha mostró que, desde la perspectiva de la exigibilidad de los derechos ciudadanos, el Estado es una parte, pero también están la sociedad blanco-mestiza y la economía del mercado donde operan las estructuras del poder colonial, por no decir que de ellas surgen los poderosos dispositivos culturales de racialización de lo negro, de exclusión e inferiorización afro, indistintamente. La debilidad de las organizaciones afroquiteñas se desprende de una perspectiva de defensa cultural alineada prioritariamente con el Estado, descuidando la acción colectiva 
en los campos de la economía y la sociedad, desde los cuales, conjuntamente con el Estado, se configuran las estructuras sistémicas de la hegemonía cultural de la modernidad colonial de la ciudad.

Así, el camino organizativo emprendido por el pueblo afroquiteño empezó como reacción a la discriminación racial, exclusión social y estigmatización violenta a los negros ejercida en la ciudad. Se organizaron con el propósito de visibilizar la existencia de negros urbanos, ante la naturalizada ruralidad que los consideraba como extraños amenazantes. El ciclo por el que atravesó la lucha de los afroquiteños tuvo tres momentos.

La paulatina conformación de las organizaciones de base en los barrios periféricos con asentamientos negros, apoyada por los misioneros combonianos y los animadores de las CEB, formando organizaciones de afinidad en torno a las identidades culturales afro. Luego, le sucedió la activación de la presión colectiva del pueblo afroquiteño, mediante marchas y plantones que demandaban parar las agresiones y por la dignidad de los afroecuatorianos, con la formación de las OSG que incursionaron en el espacio público capitalino. Y finalmente, el proceso desembocó en la gestión corporativa de las demandas del pueblo afroquiteño por parte del municipio capitalino, con la adopción de una modalidad pública comunitaria adscrita a la institucionalidad municipal, desde la que se implementó la agenda del pueblo afroquiteño.

Subyace en su camino organizativo, al igual que en el de otros sectores populares urbanos, una variante del imaginario político que atribuye un rol activo a la movilización y a la toma festiva del lugar cuando el Estado, en este caso el municipio, no da las respuestas a las demandas que levantan las organizaciones sociales. Las marchas, plantones y tomas se hicieron para presionar por las acciones afirmativas municipales en la ciudad, ante los hechos de discriminación y violencia, exigiendo reconocimientos, reparaciones y una legislación que sancione y eduque para que no se vuelvan a repetir. Una vez integradas en la estructura municipal, la movilización de las organizaciones afroquiteñas se desactivó, mostrando su carácter reactivo.

No obstante, las acciones emprendidas entre el municipio y las organizaciones de afrodescendientes muestran avances importantes en 
el reconocimiento de los derechos y la defensa de la cultura afroquiteña, pero todavía se requiere continuar en el camino de la ciudadanía diversa e inclusiva, abriéndose hacia la sociedad y la economía desde la diferencia cultural afro, para la erradicación del racismo y el estigma violento de los negros en la ciudad.

\section{Las movilizaciones sociales en defensa de la capitalidad}

En Quito, durante la transición y consolidación del distrito metropolitano, las luchas sociales no han ocurrido solo por causas relacionadas con la segregación urbana y la discriminación cultural, ni atañen únicamente a las potenciales expresiones de acción colectiva del pluriverso popular urbano. También las clases medias y acomodadas de la ciudad protagonizaron movilizaciones multitudinarias de disconformidad política que condujeron a los derrocamientos presidenciales, a las que me referiré, muy someramente, mediante algunas de las publicaciones académicas que analizaron los levantamientos sociales acaecidos entre los años 1997 y 2005, en el tránsito del siglo XX al XXI, cuando la ciudad entró en un inédito y convulsionado ciclo de protestas urbanas y movilizaciones políticas.

En la efervescencia social se sobrepusieron los protagonismos de los gobiernos central y metropolitano, se solaparon las movilizaciones nacionales con las marchas locales, emergieron nuevos protagonismos colectivos que tuvieron como referencia semántica la agresión a la capital, el asedio a la ciudad o la toma de Quito, activándose lo que he denominado la "movilización urbana en defensa de la capitalidad".

Con este apelativo me refiero a la capacidad de cohesión cultural de las élites y las clases acomodadas quiteñas que, coaligadas entre grupos de presión, gremios empresariales, notables, medios de comunicación masivos, autoridades locales y organizaciones no gubernamentales, canalizaron una percepción aristocrática de aversión a las amenazas externas, recrearon un simbolismo colonial de convivencia metropolitana y ratificaron su protagonismo privilegiado, incitando o atenuando las movilizaciones urbanas en custodia de la capitalidad. 
Cabe recordar que la ciudad ha sido el escenario predilecto para la exhibición simbólica del triunfalismo de la modernidad criolla. Por su condición de capital del país, ha sido el escenario histórico de los recurrentes golpes de Estado, de los cuartelazos militares por sucesiones del poder o intentos de desestabilidad gubernamental, de conspiraciones partidarias, o de balaceras palaciegas y refriegas callejeras entre militares y policías dirimiendo su profesionalización.

Igualmente, fue la arena de lucha de las emblemáticas huelgas nacionales, de las movilizaciones populares y de las marchas campesinas primero y luego indígenas en la segunda mitad del siglo XX; muchas de ellas contaron con importantes apoyos y movilizaciones de los barrios populares. Las calles y plazas de la ciudad, en repetidas ocasiones, fueron ocupadas por fuerzas militares y de seguridad en nombre del orden y la paz, y por nutridas marchas de sus habitantes que intervinieron en movilizaciones populares en respaldo o rechazo a los eventos políticos.

Lo común de estos sucesos es que tuvieron como referente al Gobierno nacional, la centralidad estatal o controvertidas decisiones públicas sectoriales, y simbólicamente arremetieron contra los signos del poder estatal, cuyo epicentro es el Palacio de Carondelet, como se le llama en Quito a la sede central del Gobierno ecuatoriano, y en sus desenlaces disiparon tensiones políticas en las que estaba en juego el sistema democrático, el presidencialismo y determinadas demandas gremiales, sectoriales y populares. En estas movilizaciones sociales no se puso en riesgo la capitalidad del país, la ciudad no fue amenazada, ni se enfocaron las presiones políticas contra el municipio quiteño, o este asumió algún rol protagónico frente a los conflictos nacionales.

Durante el ciclo de movilizaciones local-nacional, que se vivió en Quito, se anudaron múltiples elementos, algunos de naturaleza estructural como la crisis fiscal derivada de la deuda externa y las políticas de ajuste implantadas por los gobiernos precedentes, la persistencia de despóticos estilos caudillistas y cacicales en el ejercicio de la autoridad, los regímenes políticos que obstruyeron cualquier atisbo de cultura democrática en la sociedad quiteña y el predominio de mecanismos legales de expresión política que socavaron la legitimidad del sistema de representación (Echeverría 2009, 52-3). 
Las tres coyunturas de derrocamientos presidenciales tuvieron alcance nacional y carácter estructural, ya que estuvieron relacionados con la crisis de la institucionalidad democrática del país e involucraron múltiples actores: partidos políticos, Congreso Nacional, círculos de notables, Fuerzas Armadas, cámaras empresariales y medios de comunicación. Se tejieron, en cada coyuntura, abigarradas tramas de intereses, presiones y decisiones, cuyo desenlace condujo a sucesiones presidenciales en contextos de dudosa legalidad, situaciones en las que las movilizaciones sociales quiteñas fueron decisivas.

Precisamente repaso un aspecto específico de dichos eventos: las conexiones culturales de los discursos en "defensa de la capital", y los estratos sociales movilizados por lo que las élites y clases acomodadas quiteñas consideraron como "amenazas a la capital". A primera vista, las movilizaciones se mostraron como reacciones colectivas ante situaciones públicas consideradas localmente como intolerables, pero tras la euforia de las protestas se expresaron valores y prácticas de racismo, exclusión y menosprecio por aquellas personas, gobernantes y organizaciones consideradas "extrañas a la ciudad", remembranza reactiva a lo ajeno surgida con la expansión metropolitana.

Eran prejuicios de desprecio y estigmatización compartidos que afloraron - fueron provocados puedo decir- por la presencia de personajes y actos simbólicamente ajenos a las prácticas de convivencia política en la capital, en los eventos contra Bucaram y Gutiérrez, o con indiferencias interesadas que ratificaron seculares discriminaciones racistas a los indígenas, como ocurrió en los sucesos en torno a la destitución de Mahuad. Prejuicios que en realidad también afectaron, y afectan, a la mayoría de los propios sujetos sociales congregados en defensa de la capital.

Fueron tres coyunturas de aguda crisis del sistema de representación, acentuadas por la efervescencia de las movilizaciones sociales, y con momentos de exhibición simbólica del triunfalismo capitalino, en los que con lenguajes peyorativos, herederos de la retórica discriminadora quiteña, rechazaron las amenazas externas. Expresaron una suerte de resurgir alegórico, en los espacios públicos, del quiteñismo arraigado en el inconsciente de las prácticas cotidianas de socialización de las clases medias capitalinas. 
Las movilizaciones sociales, al tiempo que estigmatizaron a los agentes portadores de las amenazas, ratificaron el orden jerárquico de la sociedad quiteña. Se encauzaron para conjurar las coaccionas externas con los derrocamientos presidenciales y no con fines de insubordinación del orden metropolitano, ni de constituirse en gérmenes de luchas sociales contrasistémicas, y si es que hubo algún matiz en ese sentido, fue diluido por la cohesión simbólica en defensa de la capital ejercida por las élites y clases acomodadas quiteñas.

Las movilizaciones se sucedieron en un marco de cultura política de repudio al desorden provocado por lo extraño, dado que los desarreglos propios son considerados normales por la gente quiteña. Las protestas rechazaron el autoritarismo y la corrupción pública, en que incurrieron los gobernantes del país. Con sus derrocamientos se reafirmaron valores y prácticas locales de orden, progreso y convivencia ampliamente compartidas por la población capitalina. No tuvieron el propósito de revertir las inequidades y segregaciones espaciales en las que se soporta la estructura metropolitana de la capital del país. Las movilizaciones acaecieron en una paradójica simbiosis discursiva de defensa de la capitalidad, cuestionando el autoritarismo e impericia en el ejercicio gubernamental.

Con la noción de élites ${ }^{8}$ me refiero a los distintos grupos, por "naturaleza minoritarios", con poder político y económico que ocupan posiciones encumbradas en la jerarquía social y que, en la ciudad, se ramifican en subgrupos especializados e interconectados (Diez 2003, 123), como gremios empresariales, comerciales, industriales, bancarios e inmobiliarios, de propietarios de los mayores medios de comunicación masivos, y de control cupular de las instituciones educativas, culturales y deportivas.

8 En general las élites recurren a dispositivos culturales con los que ratifican sus posiciones privilegiadas y discriminan su acceso y pertenencia, recreando la delegación que se les hace para decidir, actuar y representar a la sociedad. En relación con esta condición privilegiada de las élites que se desprende de su capacidad para mantenerse en condiciones de legitimidad, recurriendo a dispositivos culturales de poder, ver el estudio de las élites regionales de Puno y Ayacucho, y sus relaciones con los gobiernos locales, de Alejandro Diez Hurtado (2003). 
Las élites quiteñas reproducen discursos, ritualidades y liturgias del orden regulatorio de la vida cotidiana, que dan continuidad a la colonialidad del poder en la sociedad urbana, con los que moldean una opinión pública local acerca del orden metropolitano. Profesan una cultura política conservadora, ideológicamente de predominio liberal, con influencia en un decadente grupo local de partidos ufanado de la estabilidad de los gobiernos municipal y provincial. Con influencia en las expresiones mediáticas de protesta, en la adopción formal de lo que se considera como la sociedad civil capitalina, o la "alta sociedad civil" y, en general, en el establecimiento de los marcos aceptados de convivencia urbana, cívica y política metropolitana.

Las élites capitalinas ejercen cohesión cultural de modo cotidiano en la ciudad; además, durante el ciclo de movilizaciones urbanas, se conjugaron determinadas condiciones políticas que hicieron visible su función de integración ideológica, en custodia de lo que en cada situación perfilaron simbólicamente como la ciudad deshonrada, la ciudad sin memoria y la ciudad hostigada. Las tres crisis políticas estuvieron marcadas por la exacerbación social, en la que las clases medias y el movimiento indígena fueron los protagonistas.

\section{La insubordinación de la ciudad deshonrada}

La primera coyuntura de exhibición de la capacidad de cohesión simbólica de las élites y clases acomodadas quiteñas fue durante el breve Gobierno de Abdalá Bucaram, cuando en el transcurso de siete meses la ciudad de Quito se vio envuelta en un inédito conflicto político-simbólico con el presidente y su círculo gobernante. Desde el comienzo el gobierno buscó, deliberadamente, desdibujar la capitalidad de la ciudad, mediante una confusa retórica que asociaba a la capital con el centralismo estatal, lo que evidenciaba cierto resentimiento regionalista por la pérdida electoral que sufrió en Quito (El Comercio 2000, 152). El Gobierno de Bucaram no comprendió las fuerzas políticas que activó, porque desde el primer día las élites quiteñas, mediante los principales periódicos, hicieron un seguimiento detallado con coberturas noticio- 
sas, editoriales y reportajes especializados de todos los errores, desaciertos y agresiones gubernamentales a la ciudad. ${ }^{9}$

Concuerdo con Felipe Burbano en señalar que las constantes impericias oficialistas fueron vistas localmente como transgresiones al orden simbólico del poder regional, y dieron lugar a una conjunción política de grupos de presión, opinión pública y movilizaciones multiclasistas en defensa de la ciudad, entre los que primó la convergencia de posiciones de las élites políticas e intelectuales (2009, 65-6).

De entre los numerosos desatinos en que incurrió el populismo gubernamental, cuatro conflictos contra la ciudad provocaron la respuesta de las élites y clases acomodadas quiteñas. Empezó con la reticencia del presidente a residir en el Palacio de Carondelet, lo que junto con su creciente ausencia de la capital, dado que adoptó la modalidad de gabinete itinerante, una suerte de "presidencia flotante" encabezada desde afuera de la sede del gobierno, y de las continuas y largas estancias en Guayaquil, con lo que la mayor parte del tiempo estaba fuera de la ciudad, abonó a una sensación de apatía presidencial por la capital (Hoy 1997, 39). No tardaron en entretejerse, en la opinión pública capitalina, las conexiones entre la ausencia del presidente de Quito y el vacío de gobierno, cuestión que se expresaba figurativamente en el abandono del palacio presidencial, que la prensa quiteña contribuyó a cimentar.

Gobernar al país alejado del palacio reñía con la tradición política quiteña de que el poder se ejerce desde la capital, lo contrario suponía el riesgo del "vacío de poder", por lo que corrió el rumor de una sospechosa intención del presidente de despojar a Quito de su condición de capital, según lo anunciaron los editorialistas del diario El Comercio (Burbano 2009, 68). El gobierno arguyó una vaga idea de descentralización que no implicaba ninguna transferencia de competencias a los gobiernos locales ni la delegación territorial de funciones sectoriales. Se trataba, más bien, del desbordamiento del personalismo presidencial que reñía,

9 Sobre el seguimiento de la prensa quiteña al Gobierno de Bucaram pueden verse las recopilaciones noticiosas y editorialistas acopiadas en las publicaciones de los diarios El Comercio (1997) y Hoy (1997). 
incluso, con los propulsores discursivos de la descentralización y autonomías municipales, como eran las autoridades locales guayaquileñas.

En los hechos eran simples desplazamientos del presidente que provocaban fricciones políticas por su constante ausencia del Palacio de Carondelet, acentuadas por la completa informalidad de una gestión del poder presidencial despojada de la solemnidad y el ceremonial que conlleva, que provocó el resentimiento de la ciudadanía quiteña, como lo expresó un editorialista del diario Hoy:

pero no tiene lógica alguna que el presidente permanezca en la capital de la República y por tanto sede del Gobierno tan solo unas pocas horas, luego de siete o diez días de ausencia. Al punto que esta actitud solo puede entenderse como una reacción negativa frente a la ciudad, a su clima, a la forma de ser y a la cultura de su gente. Al menos así lo han interpretado los habitantes de Quito y están enojados, ofendidos, resentidos con el presidente. $(1997,132)$

Bucaram alteró la relación entre legitimidad del poder y sede del Gobierno, porque despachaba llanamente desde cualquier lugar, lo que resultaba deshonroso para Quito como capital del Estado-nación. Como lo señaló Burbano, con ardorosa elocuencia, los diarios capitalinos arguyeron sobre la importancia simbólica del Palacio de Carondelet como sede del Gobierno nacional y la unidad de la patria, hasta que, en el paroxismo de la crisis gubernamental, dos días antes de la caída del presidente, el diario Hoy anunció que Bucaram retornaba tardíamente a Carondelet para tratar de gobernar: "Su presencia en el Palacio de Gobierno en la agonía de su régimen confirma que muy tarde intentó comprender lo que significa la Patria y sus lugares" (Burbano 2009, 71).

En paralelo, desde el inicio del Gobierno, otro embate contra la capitalidad fue el intento, también confuso en sus argumentos, de nombrar un gobernador para la provincia de Pichincha, blandiendo un abstruso discurso de las funciones de la centralidad respecto de las provincias y que se cernía amenazante sobre la capital y su provincia, lo que fue interpretado como un atentando a la autonomía de los gobiernos seccionales y provocó el rechazo de todos los alcaldes pichinchanos. Se sumó la pretensión del hermano del presidente de llegar a la Alcaldía 
de Quito, lo que traslucía el interés del grupo gobernante por el control político de la ciudad, cuestión que resultaba intolerable en varios círculos quiteños.

Este personaje también intentó crear un organismo público autónomo del tipo unidad ejecutora de servicios y obras para Pichincha, integrada por varios diputados electos, las dos autoridades provinciales y con presupuesto propio que, en el peor estilo clientelar, buscaba competir en la prestación de bienes y servicios con los municipios y la prefectura. La iniciativa no prosperó en el Congreso, pero dejó entrever sus intenciones políticas y dio lugar a la creación del Frente Político en Defensa de Pichincha, para vigilar al gobernador y su grupo (2009).

La polémica subió de tono cuando el Ministerio de Gobierno expidió la normativa para la Gobernación de la Provincia de Pichincha, eran veinticinco funciones que daban al gobernador toda la autoridad y las atribuciones de control policial y fiscalización sobre los gobiernos provinciales y municipales, así como de las instituciones privadas que tenían relación con el Estado. El alcalde de Quito declaró inconstitucional la normativa, y se zanjó el diferendo disminuyendo las atribuciones del gobernador sobre los municipios y prefectura.

La tensión con el presidente continuó en vísperas de las fiestas de Quito, en las que para un sector minoritario y de ademanes exhibicionistas el acto central eran las corridas de toros, la Feria de Jesús del Gran Poder, con la que desde hace cincuenta años se celebraba artificiosamente la fundación española. El gobierno anunció la prohibición de la muerte de los toros en las corridas que se realicen en el país. El anuncio tenía la intención de distanciar a las élites quiteñas de los sectores populares, pero, al contrario, activó una nueva y agria polémica entre las autoridades gubernamentales, los editores taurinos y la afición que, en cerca de quince mil personas, se arrogaban la representación identitaria de la ciudad (2009). Nuevamente, minorías que hablan por la mayoría.

Un compartido discurso elitista y municipal puso en el centro del debate la defensa de una forzada identidad hispanoamericana de la población capitalina, entretejida con una memoria de blanqueamiento de lo indígena y lo afro, que se encarnaba en la fiesta taurina como imagen 
cohesionadora de la identidad blanco-mestiza quiteña. Los argumentos del debate, más que revelar el enraizamiento cultural de un festejo que se pretende compartido, cuando en realidad se caracteriza por su carácter socialmente excluyente, ahondaron en incubar el desprecio contra el gobierno costeño, tildándolo de presidente extraño a una ciudad y nación mestizas (Saad 1997).

A más de los abucheos y silbatinas contra el gobierno en las corridas de toros, las amenazas presidenciales no se cumplieron, pero mostraron que en realidad lo que ocurría era que, bajo el liderazgo del alcalde y secundados por las élites empresariales y los periódicos quiteños, se estaba "organizando la defensa de Quito", movilizándose sus símbolos culturales en oposición al presidente (Burbano 2009, 82). Desde el inicio de su Gobierno, Bucaram buscó enfrentar y deslegitimar al municipio quiteño, como lo evidenció un editorialista del diario Hoy:

Y ya en el poder el Gobierno ha puesto en marcha una serie de maniobras con el propósito de limitar la acción municipal, recortar sus rentas, coartar sus iniciativas e, inclusive, desprestigiar a los personeros municipales con acusaciones tendenciosas sobre supuestos malos manejos de fondos $(1997,132)$.

La tensión recrudeció con el cerco que tendió el Gobierno nacional al municipio capitalino y con el ataque a su alcalde recién reelecto. Estimuló la convocatoria a la Asamblea de la Ciudad (75), la que se convirtió en el espacio de convergencia de los distintos sectores que, paulatinamente, organizaron la defensa de la ciudad, de sus valores y tradiciones "mancilladas", proyectando dos símbolos mediáticos poderosos: una "ciudad agredida" y una "ciudad de todos" (Burbano 2009), que encarnaban un claro enfrentamiento político entre el Gobierno nacional y el poder regional.

La Asamblea de la Ciudad era parte de la conversión del municipio en gobierno local, establecida en el Plan Estratégico de transición a distrito metropolitano, que se encontraba en pleno proceso de acercamiento a los barrios populares para cambiar la imagen elitista del municipio, cuando se interpuso la arremetida de Bucaram, convirtiéndose, de facto, en el espacio de oposición de las clases altas al gobierno, del 
cual emergió un fugaz discurso integrador de la capitalidad que supo utilizar el alcalde, uniendo las imágenes de las dos ciudades (2009). La Asamblea de la Ciudad decidió unirse al paro nacional de dos días convocados por los movimientos sociales y llamó a las marchas desde distintos sitios de la ciudad para llegar al Congreso y pedir la destitución del presidente, dando lugar a nutridas movilizaciones multiclasistas que mostraban cierta unanimidad en medio de las diferencias culturales, y matizadas por expresiones de alegría, humor, regionalismo y xenofobia (Saad 1997, 41-8), que mostraban el desprecio a lo ajeno.

En el paro nacional convergieron tres fuerzas sociales: el FUT, el Frente Popular cercano al Movimiento Popular Democrático (MPD) y la Coordinadora de Movimientos Sociales vinculada a Pachakutik y a sectores energéticos, que formaron el Frente Patriótico con el mandato popular de pedir la renuncia de Bucaram y cambiar el sistema político económico vigente en el país. Durante el paro cívico la coordinadora desplazó al FUT, y por primera vez en el país se hizo una huelga nacional que no era liderada por los sindicatos (El Comercio 2000, 215-21).

Para anunciar el paro la Coordinadora de Movimientos Sociales se tomó la Catedral Metropolitana, en la Plaza de la Independencia de Quito, como símbolo de protesta y centro de operaciones, acompañándole intermitentes levantamientos indígenas, bloqueos de carreteras, paros de transportistas que provocaron desabastecimiento de combustibles y alimentos, unificándose las protestas sociales en la huelga nacional contra del gobierno (Hoy 1997, 14-6). En expresión simbólica de la máxima unanimidad opositora, seis excandidatos presidenciales, dos expresidentes, los diputados jefes de bloques de oposición y la Coordinadora de Movimientos Sociales firmaron una petición de destitución de Bucaram al Congreso. Con ello las fuerzas políticamente antagónicas se unieron con el mismo propósito: "el presidente supo unir en su contra el agua y el aceite" (15) sentenció la prensa quiteña.

La defensa de Quito, como epicentro de la oposición a Bucaram, se regó al país y las nutridas manifestaciones de rechazo al régimen se multiplicaron en Guayaquil, encabezadas por su alcalde, y en Ambato, Cuenca, Azogues, Ibarra y Guaranda; también la gente se tomó las pla- 
zas de Riobamba, Machala, Lago Agrio, Puyo y Tena, estimándose que más de dos millones de personas realizaron protestas callejeras en oposición al gobierno, pese a las intensas lluvias invernales (150-2).

Bucaram había atacado a la capitalidad del país confundiéndola con el centralismo gubernamental, por lo que las élites y gentes quiteñas sintiéndose amenazadas organizaron la defensa simbólica y política de la ciudad. Las movilizaciones sociales, si bien juntaron disímiles estratos sociales y fuerzas populares organizadas, en Quito predominó la presencia de mujeres y hombres de las clases altas con representaciones barriales, gremiales, empresariales e intelectuales que, coincidiendo con los sectores populares, lideraron la oposición al gobierno (82). Los discursos públicos y las movilizaciones sociales en defensa de la capital revelaron la capacidad de convocatoria de las élites quiteñas, convertidas de facto en el epicentro de una lucha ciudadana activada por las amenazantes extravagancias y chabacanerías del "extraño" gobernante que había despreciado a la ciudad (Burbano 2009).

El rechazo y la expulsión de Bucaram confirieron un sentido de cohesión a las movilizaciones sociales de las clases medias y altas en defensa de la capital, que supieron aprovecharse del alineamiento de los sectores populares y grupos de izquierda movilizados contra el Gobierno.

\section{La toma de la ciudad sin memoria}

La segunda coyuntura en que se visibilizó la cohesión ideológica de las clases acomodadas quiteñas, nuevamente en defensa de la ciudad ante lo que se consideró otra amenaza externa y que reeditó el sentido de la defensa simbólica de la ciudad, fueron los episodios que derrocaron al Gobierno de Jamil Mahuad. Se trató de un momento diferente, por las condiciones del país y los actores que intervinieron, pues el presidente al que se destituyó era nada menos que el exalcalde de Quito, quien se convirtió en la figura central en la oposición a Bucaram. Tres años más tarde, era despojado del respaldo ciudadano y simbólicamente destituido por un estigmatizado movimiento indígena.

Las clases acomodadas quiteñas, que antes habían patrocinado al burgomaestre, ahora indiferentes y al mismo tiempo beneficiadas por 
las medidas gubernamentales, se mostraban dispuestas a destituir al presidente, sin modificar su improvisación económica, manipulando el vacío de gobierno recurrente en la cultura política ecuatoriana, con el que aislaron al movimiento indígena y al grupo militar que dio el empujón final a la caída de Mahuad.

Los eventos que propiciaron esta nueva coyuntura pueden resumirse en los siguientes términos. En poco tiempo el Gobierno interino de Fabián Alarcón había dejado las finanzas públicas con un déficit equivalente al 6 \% del PIB. En esos mismos días del año 1998, el país sufrió los efectos devastadores de las inundaciones provocadas por el fenómeno de El Niño, que destruyó carreteras, infraestructura y extensas áreas cultivadas y ganaderas en la Costa ecuatoriana, lo que representó una pérdida del 14,5 \% del PIB nacional, afectando a los principales productos de exportación (Larrea 2004, 36). La restricción de las agroexportaciones afectaron a algunos de los bancos privados que arrastraban una crisis financiera, por el rápido retiro de capitales especulativos a los mercados financieros emergentes y el corte de líneas de créditos internacionales, que acentuaron las carteras vencidas.

La crisis financiera era cubierta parcialmente por el excedente petrolero, aunque los precios del petróleo habían experimentado una caída progresiva desde 1996, recién en abril de 1999 tuvieron una leve recuperación que no bastó para impedir la aguda crisis fiscal, ya que los ingresos petroleros representaban el $40 \%$ de esos ingresos en el período 1991-2000 (33). Los gobiernos precedentes financiaron complementariamente el presupuesto público con un creciente endeudamiento externo, lo que repercutió en la vulnerabilidad de un sistema financiero privado, acostumbrado al libre manejo de los negocios. Eliminaron los programas de crédito dirigido, redujeron al límite los requerimientos de la reserva monetaria y liberaron las tasas de interés, con lo que los bancos privados empezaron a recibir depósitos y conceder préstamos en dólares americanos, además de realizar crecientes operaciones offshore (2004), para compensar la salida de divisas y promover su retorno en operaciones crediticias.

Se había generalizado una suerte de dolarización informal. La banca privada concedía créditos vinculados con altas concentraciones 
de cartera, pues se suponía que los bancos estaban, llanamente, para cubrir los requerimientos de financiamiento de los grupos económicos a los que se pertenecían. Las estimaciones del costo total de la crisis financiera hasta el año 2000, incluyendo la crisis fiscal y los endeudamientos nacional e internacional, sin considerar el congelamiento de depósitos, variaban entre el 22 y el $25 \%$ del PIB nacional (34).

La crisis del sector financiero puso nuevamente en evidencia la persistencia de un poroso sistema político, incapaz de resolver las profundas inequidades regionales, por lo que el arribo del presidente Jamil Mahuad vino precedido de prestigio por la administración municipal en la transición a distrito metropolitano y con la esperanza de que haría una eficiente gestión gubernamental. Al poco tiempo, la población quiteña, indistintamente de su condición socioeconómica, sintió que se trataba una vez más de un liderazgo errático y contradictorio, entregado al sector financiero. Detrás de la retórica presidencial que declaraba "consensos y armonías", se tomaban medidas inequitativas; a la explicación de la crisis económica nacional le acompañaba una política entreguista a la banca, con lo que el derrumbe del Gobierno de Mahuad se entrelazó con la crisis del sistema financiero.

Renuente a impulsar una reforma financiera, el gobierno, por medio del Congreso Nacional y respaldado en la Constitución de 1998, creó la Agencia de Garantía de Depósitos (AGD), que protegía con fondos estatales, concediendo garantías ilimitadas a los depósitos, indistintamente de su naturaleza y magnitud, y gravó con el $1 \%$ a todas las transacciones bancarias privadas (El Comercio 1998). Buscaba resguardar con recursos públicos a la banca privada que se encontraba en dificultades, negociando con cada uno de los banqueros, bilateralmente, fondos públicos a cambio de respaldo político. No era más que un viscoso clientelismo con la banca privada, disfrazado de salvataje bancario.

En la medida en que se acrecentó el auxilio a la banca, también se aceleró la caída del sistema financiero. Mahuad, en un intento por contener la crisis, por medio de la Superintendencia de Bancos, declaró el "feriado bancario" por un día que en realidad duró cinco (El Comercio 1999). Inmediatamente dispuso el congelamiento por un año de los 
fondos de las cuentas corrientes superiores a quinientos dólares y cuentas de ahorros con fondos superiores a mil dólares; argumentó su decisión como una salida a la exagerada hiperinflación que decía iba a cerrar en $1000 \%$ en el año 1999, como protección de la reserva monetaria que con doscientos millones de dólares (1999), lo que permitiría bajar el precio del dólar y programar la devolución de los depósitos incautados.

Según algunos analistas, la crisis bancaria no era generalizada en todo el sistema bancario privado, solo unos cuantos bancos estaban quebrados, a los que el gobierno pretendía salvar trasladando sus costos a los depositantes. Cuestión que se evidenció con el inminente cierre del Banco del Progreso por falta de liquidez, en el mismo mes en que se tomaron las medidas, y fue el preámbulo del cierre de los demás bancos quebrados un año antes: Banco de Préstamos, Filanbanco y La Previsora. En reacción al cierre bancario, en Guayaquil se dio la "marcha de los crespones negros" (1999), liderada por el alcalde y apoyada por las cámaras empresariales del puerto.

Las crecientes denuncias de los aportes de la banca quebrada a la campaña presidencial de Mahuad pusieron al descubierto la enorme corupción de la banca y el propósito gubernamental de proteger de la crisis bancaria a los principales financistas de su campaña electoral. Como lo señaló Luis Verdesoto $(2014,286)$, el presidente en su afán de ser el salvador de los banqueros, por delegación de los propios banqueros se convirtió en el responsable de la crisis financiera ante los ahorristas y la población, quienes "pasaron de la desconfianza al absoluto antagonismo".

La crisis se precipitaba. El gobierno no logró firmar la ansiada carta de intención con el Fondo Monetario Internacional (FMI), por lo que cayó en moratoria en el pago de la deuda externa. Tampoco obtuvo suficiente respaldo de los partidos políticos en el Congreso para aprobar el presupuesto público del año 2000, ante lo cual el presidente negoció el apoyo con el Partido Roldosista Ecuatoriano (PRE), a cambio del retorno de su depuesto líder, lo que en Quito, promovido por el diario El Comercio, prendió "las alertas sobre el posible regreso de Abdalá Bucaram” (1999). La prensa quiteña había forjado un interesado paralelismo 
entre Mahuad y el presidente derrocado, con lo que su destino no podía ser diferente (Córdova 2003, 39).

Casi de inmediato el expresidente León Febres Cordero demandó que "Mahuad debe renunciar a su cargo", a los pocos días el alcalde de Guayaquil declaró que "el plazo para que Mahuad renuncie ha concluido” (39). A finales de diciembre se había materializado el símbolo de una apostasía presidencial, cuando se anunció una reforma al Código Penal, negociada por iniciativa del gobierno, que abría el camino para el retorno de Bucaram, amenaza que fue nuevamente alertada por el periódico El Comercio que tachaba al presidente de traidor a su propia “acción heroica” de febrero de 1997, cuando se derrocó a Bucaram (39). Los efectos políticos de su cercanía con el estigmatizado expresidente no tardarían en manifestarse.

El Gobierno de la democracia cristiana, indiferente a las críticas, mediante el BCE y buscando detener la caída de las reservas internacionales, adoptó una política de flotación del tipo de cambio, con lo que al poco tiempo el sucre perdió drásticamente su valor frente al dólar que ya venía en escalada: en 1998 pasó de cuatro mil sucres a diez mil, en 1999 subió a quince mil, en el mes del congelamiento bancario alcanzó los dieciocho mil y en enero de 2000, cuando se decretó la dolarización, llegó a veinticinco mil. El índice de precios al consumidor se disparó, la inflación igualmente al alza fue del 36 \% en 1998, subió al 56 \% en 1999 y llegó al 97 \% en 2000 (El Comercio 2014). El temor a la hiperinflación se generalizó en el país.

El presidente, alineado con la banca guayaquileña que presionaba por una liberalización total, tomó la medida severa: el 9 de enero de 2000 decretó la dolarización que reemplazó la moneda nacional por el dólar norteamericano (El Comercio 2000a). La dolarización y el congelamiento bancario, con la retención de los depósitos, provocaron el más agudo empobrecimiento de los sectores populares y medios, acentuando su masiva emigración. Un sentimiento pesimista agorero de la ausencia de futuro se diseminó en la ciudad y en el país, acompañado por una sensación generalizada de desesperanza, pues esbozada en la retórica presidencial de progreso se proyectaba un país quebrado, sin mañana. Las imágenes 
derrotistas fueron, interesadamente, avivadas por un "clima de opinión" que combinaba los valores morales con la retórica periodística, orientados a crear un ambiente local de desmovilización social y de consenso sobre la destitución presidencial (Córdova 2003, 40).

El gobierno apenas pudo paliar la crisis bancaria, mostrándose incompetente en el manejo público del mandato popular. Erosionó su legitimidad política, llevando al régimen a menospreciar los crecientes y múltiples pedidos de rectificación gubernamental, con lo que, abandonado a las presiones sociales, indefectiblemente, precipitó el vacío de poder, dando continuidad, nuevamente, a una sensación de ausencia de gobierno (Verdesoto 2014, 287). En enero de 2000 la ciudad de Quito y el país asistieron a una oleada de denuncias y pedidos de renuncia del presidente, diligentemente difundidos por la prensa (Córdova 2003) que amplió el radio de opositores al gobierno.

Mahuad había llegado al nivel más bajo de aceptación popular (4\%), por debajo de Bucaram (6\%), con lo que una a una las fuerzas políticas se alinearon en la oposición al gobierno, las cámaras y gremios empresariales le retiraron su apoyo, nuevamente las presiones regionalistas contra el centralismo quiteño recrudecieron, los sectores populares organizados protestaban, incluso su propio partido político y los más cercanos colaboradores le pidieron que enmiende o se retire (Paz y Miño 2002, 24-5). Ni el clientelismo bancario evitó que el gobierno quede en completa orfandad política y condenado al mayor repudio social y político a su gestión. En poco tiempo las medidas tomadas por Mahuad provocaron la ira popular, el desconcierto de ahorristas y jubilados, la desarticulación del frente económico y un precipitado desmembramiento de su gabinete. A la vista de toda la ciudadanía, por su propia inercia, inexorablemente se derrumbaba su Gobierno.

Estimulados mediáticamente, los recuerdos quiteños de los eventos de Bucaram contra la capital estaban frescos, cuando circuló una nueva proclama simbólica de "toma de la ciudad" (Hoy 2000) por parte del movimiento indígena que lideraba la oposición al gobierno. Anuncio que el presidente, pese a su descrédito, lo calificó como una "pretensión", y que los medios de comunicación, al servicio de las élites y clases 
acomodadas quiteñas, supieron separar, aislar, de la inminente caída del presidente. Aupadas en una actitud de desprecio e indiferencia a los indígenas, las élites y clases acomodadas con la utilización mediática del temor a la presencia de aquellos "grupos ignotos", vistos como unas "hordas de extraños" que amenazaban con atestar las plazas y avenidas de la capital del país mestizo (Hoy 1999), que estaban expuestas a los "excesos del indigenado" (Expreso 2000), mostraron su secular indiferencia al anuncio indígena.

Sabían que al presidente reaccionaría buscando la reconciliación simbólica con el poder. Así ocurrió. El Gobierno manipuló la proclama de toma de la ciudad, resucitando inconscientes y atávicos temores idiosincráticos de las gentes quiteñas, ante el peligro de saqueos y asaltos que ocurrirían con la masiva presencia de los indios, provocada por la catastrófica facundia de la prensa que convirtió el "miedo al Otro" (Córdova 2003,52 ) en un gran desmovilizador social.

Como acertadamente analizó Gabriela Córdova (2003), la prensa capitalina lideró una cruzada mediática que decía que lo que estaba en juego no era el rompimiento entre el Gobierno y el país, sino el reemplazo de una autoridad deficiente, y había que contrarrestar a los indígenas irruptores, cuya posición beligerante bloqueaba el diálogo y ahondaba la crisis del país. Por maniobras mediáticas, los indígenas fueron convertidos de opositores al Gobierno en contrincantes del pueblo, y que no tenían derecho a conducir el país; por tanto, su presencia en ese momento no era legítima: "en esta ocasión el levantamiento no ha sido como los anteriores, no cuentan con la adhesión suficiente como para comprometer la estabilidad del régimen, más preocupado en dar forma a un vuelco en el sistema monetario, la dolarización” (48), declaró la prensa capitalina que proyectaba una visión inopia del movimiento popular.

En la tradición oral de los pueblos indígenas el valor de la palabra es decisivo. Para las culturas indígenas el mensajero es tan importante como el mensaje, ya que los conocimientos y sus prácticas están corporeizados en un intercambio permanente entre lo material y lo inmaterial, pues en el mundo oral las personas y sus contextos están relacionados por un flujo continuo, mediado por la corporalidad (Marcos 2006). 
Los indígenas marcharon desde diferentes lugares a Quito, precisamente para escuchar directo, de boca de Mahuad, el esclarecimiento de la crisis; querían lograr un compromiso con su presidente para salir de la desesperanza, por lo que diversos pueblos indígenas acompañaron a sus dirigentes al diálogo personal con la autoridad; pero el presidente no quería el diálogo, solo daba señas de distanciamiento y desprecio hacia los indios, los prefería lejos (Hoy 1999) de la ciudad.

La primera entrada a Quito en pos del diálogo fue a comienzos de junio de 1999. El presidente preparó a la ciudad para la llegada de los indios, a los que calificó como unos advenedizos que intentaban copar los espacios públicos, ordenó al ejército amurallar con alambre de púas los edificios públicos, cerrar los accesos a la ciudad, rodear con tanques la sede del poder y vigilar desde el aire el avance de la "turba sin nombres ni identidades" (1999). En el editorial del diario Hoy, en referencia a la marcha a la capital, se dijo que:

La ceguera del poder fue tal, ceguera o miedo, que arrojó cobardemente en las vías trozos de vidrio para que los indios sintieran lo que significaba la pretensión de llegar a la capital de los "blancos". Para que volvieran a sentir el peso de la violencia mestiza. (Ponce 2000, 24)

Los indígenas atravesaron los cercos militares y tomaron simbólicamente la ciudad. La noche del 17 de junio forzaron al presidente a firmar algunos acuerdos inesperados como el congelamiento de los precios del gas, de los combustibles y el freno a la eliminación de los subsidios, acuerdos que fueron incumplidos por el Gobierno, lo que, se estima, sirvió para que se promuevan los contactos políticos entre indígenas y militares, al punto que pocos días después la CONAIE realizó su congreso en pabellones militares (11).

Seis meses más tarde, a mediados de enero de 2000, el movimiento indígena nuevamente entró a la ciudad, esta vez en alianza política y táctica con los mandos medios militares y la Coordinadora de Movimientos Sociales, en torno a una agenda discursiva de derrocar al Gobierno para cambiar la estructura del país, frenar la corrupción, sancionar a los banqueros y devolver el dinero incautado, impulsando un Gobierno democrático de indios, pobres y honrados, con nuevos parla- 
mento y justicia, y lograr la transformación social de Ecuador (Herrera 2001, 34-5). Proclamaba una agenda política de cambio social.

Aunque los medios de comunicación y determinados sectores de la población quiteña reaccionaron abundando en expresiones de racismo, discriminación y desprecio por lo indio, las élites y gentes quiteñas no dieron mayores señales en defensa de la ciudad, que no fuera sumarse al desprecio del gobierno por los indios, considerados en el escalón más bajo de la estructura social. Su presencia, aunque no deseada, no representaba una amenaza a la capitalidad, bastaba con la indiferencia y el menosprecio; además, el presidente estaba prácticamente caído y su gobierno al borde del despeñadero, los indios no podían ni iban a subvertir ningún orden social o político.

Encabezando la oposición, el movimiento indígena organizó en el trayecto a la capital sucesivos Parlamentos Provinciales de los Pueblos, en los que configuró un mandato popular de redistribución de la riqueza, sanción a los banqueros corruptos, renovación de la justicia, y un nuevo Gobierno de transformación social en favor de los indios y los pobres (34-5). Nuevamente llegó a Quito burlando todos los cercos militares con los que el gobierno trató de impedir su acceso a la ciudad, paulatinamente se fueron reagrupando en el parque de El Arbolito, donde se estima que acamparon más de ocho mil indígenas que fueron apoyados logísticamente por vehículos militares (47).

Haciendo gala de maniobras tácticas y en coordinación con los coroneles golpistas, los indígenas durante varios días protagonizaron marchas encabezadas por los dirigentes de la CONAIE, respaldados por la Coordinadora de Movimientos Sociales, sindicalistas, empleados públicos, estudiantes, pobladores y sectores populares, en un ambiente de convergencia político-cultural y de respaldo nacional popular que fue denominado como la Rebelión de Quito (Paz y Miño 2002). Gritando la consigna "Fuera Mahuad", burlaron los cercos militares instalados dentro de la ciudad y, ante el desconcierto de la mayoría de población quiteña que observaba, se dirigieron al Ministerio de Defensa para dialogar con los militares aliados.

Al siguiente día marcharon hacia la Corte de Justicia y tomaron el Congreso Nacional, previo un ritual shamánico de purificación del 
lugar, instalaron el Parlamento de los Pueblos y formaron la Junta de Salvación Nacional que pidió la destitución del presidente y nombró un triunvirato — que duró tres horas - integrado por el presidente de la CONAIE, un general que encabezó el frente militar de Mahuad y un sombrío exmagistrado de justicia promovido por una mescolanza de grupos mestizos guayaquileños (Ponce 2000, 14). Fue "el más breve golpe de Estado" que simbolizaba "la unión de los pueblos indígenas, los soldados y la ley" (Becker 2015, 72).

Un insólito desenlace ocurrió la noche del 21 de enero. El fugaz triunvirato entró a un desolado Palacio de Carondelet que había sido desocupado por las élites del poder, donde con absoluto desconcierto constataron que solo habían ocupado, literalmente, el edificio desde donde se ejerció el dominio sobre los pueblos indios (Ponce 2000, 16). No habían llegado al gobierno y menos tomado el poder, incluso no fue muy evidente que hubieran derrocado a un presidente que estaba completamente desestabilizado (Herrera Aráuz 2001, 138), sin ningún respaldo político ni de sus coidearios más cercanos.

Irónicamente, el movimiento indígena, que acababa de precipitar la caída del presidente, se encontraba solo y sin respaldo político, mostró que carecía de un plan de acción y del apoyo necesario para formar el gabinete gubernamental; constató que no tenía el mando ni sobre los guardias de las puertas del palacio que intranquilos se limitaban a observarlos (Ponce 2000, 17). El ímpetu del movimiento indígena había rebasado a sus aliados: los coroneles golpistas y la Coordinadora de Movimientos Sociales, pues la fuerza colectiva del levantamiento indígena desbordó la alianza, con lo que, aislados, los dirigentes indios habían arribado al temible vacío político. En la mañana del siguiente día, con visible sentimiento de derrota, con rabia y frustración (Herrera 2001, 177-8), abandonaron pacíficamente el palacio y emprendieron el retorno a sus comunidades.

En paralelo a los eventos de la alianza coroneles-indios, las cúpulas militares y las élites políticas habían tranzado, la madrugada del 22 de enero, la salida constitucional a la crisis con la subrogación del presidente y la asunción al mando del vicepresidente de la República, representan- 
te de las tradicionales familias patricias guayaquileñas. La estrategia del Comando Conjunto de las Fuerzas Armadas era desalojar del poder a los indios, someter a los militares, desconocer a los dirigentes de los movimientos sociales y entregar el poder al vicepresidente, cumpliendo con la sucesión constitucional (165). Se había consumado el reemplazo institucional de la ineficiente autoridad presidencial, anunciada con antelación por la prensa y los medios de comunicación capitalinos.

Esa misma madrugada las autoridades militares enviaron un emisario para que dialogara con los coroneles insurrectos y se sometieran al mando castrense. Al poco tiempo, todos los líderes indígenas y militares que participaron en el derrocamiento tuvieron el armisticio del Congreso Nacional, con lo que la mayoría de analistas coinciden se selló la posibilidad de conocer en profundidad los eventos de esa "extraña alianza" que se movilizó para derrocar a un presidente que prácticamente estaba caído. Miguel Lluco, uno de los líderes de la toma de Quito, reflexionando sobre su significado, explicó:

Fue una fiesta. Una combinación de rebeldía, de ira, pero también de alegría. Si nosotros pensamos en las fiestas de San Juan, de San Pedro, vemos que, a través de la fiesta, cualquier rencor se expresa en ese momento: rencor, ira en contra de la maldad de las autoridades. Por otro lado, también vamos haciendo la fiesta para que el enemigo se ponga menos cauteloso. (Ponce 2000, 27)

Como argumentó Javier Ponce (2000), la toma simbólica de la ciudad como centro del poder fue considerado por los quiteños como un asedio, una intimidación, mientras para los indios era un ritual, una celebración, una combinación de "rebeldía y fiesta"; las dos entradas a Quito estuvieron encabezadas por los diablohumas que danzando espantaban los malos espíritus, expulsaban las maléficas energías de las calles con limpias de ramas y fustas, algo incomprensible para los habitantes de la ciudad que atónitos observaron los acontecimientos desde las pantallas de televisión (27). Solo unos pocos de los más humildes pobladores de los barrios periféricos, en sintonía cultural con las ritualidades indígenas, acompañaron el ingreso de los indios y se sumaron a las marchas de protesta durante los días de la ocupación de Quito. 
Los indios llegaron a la capital del país mestizo y se encontraron con la ciudad de la memoria perdida, en la que pareciera haber un vacío identitario por la constante negación de las identidades, una ciudad donde "la memoria lucha con la memoria" (163-4). Una ciudad en la que los medios de comunicación y las autoridades negaban, desconocían, la identidad de los otros, de los pueblos indígenas, pese a que pocos años antes, en la década de los 90 del siglo pasado, el movimiento indígena entró de facto en la escena política nacional, luego de impactantes levantamientos y marchas por todo el país, cuestionando el carácter nacional del Estado y planteando una tesis innovadora como la del Estado plurinacional, a la que adhirieron amplios sectores sociales y populares que veían representados sus intereses (Becker 2015). El movimiento indígena se asumía como una avanzada político-cultural en la creciente ola de movimientos sociales y populares del país.

Durante los días de la toma de Quito y los posteriores, la prensa fraguó la imagen de que con los indios no cabe la igualdad, sino solo políticas gubernamentales asistenciales, paternalistas; reprodujo la naturalización de su ruralidad: mientras permanezcan en sus comunidades no son una amenaza, cuando las abandonan y vienen a la ciudad, se tornan en sujetos peligrosos para la estabilidad institucional. No les corresponde tomarse la ciudad, al andar por sus calles fueron señalados como usurpadores. El estigma de su inferioridad se difundió. Los líderes indígenas fueron acusados de pretender modificar su condición de dominados, ingresando a los lugares que no les corresponden y sin el blanqueamiento adecuado (Córdova 2003, 55). Se había reeditado en la capital el fantasma de la amenaza de lo marginal.

La prensa y los líderes de opinión, en defensa de la democracia, supieron manipular a la clase media capitalina, creando un enfrentamiento entre el pueblo mestizo y el "populacho étnico", los indios, por el que se buscaba la salida del presidente, preservando la institucionalidad, frente al caos y la incertidumbre provocados por la irrupción del otro; los sectores medios estaban a favor de la salida del presidente, pero no de la conducción indígena. La opinión pública había desplazado la imagen del enemigo, el miedo aisló a la acción indígena y la institucionalidad encontró en él a su mejor aliado, concluye Córdova (57). 
Así, no obstante su relevancia política como actor contestatario surgido desde la alteridad, no era legítimo que los indios tomaran simbólicamente la capital del país, ocuparan festivamente sus avenidas y plazas y entraran a un palacio presidencial desocupado, en el que no había nada que hacer que no fuera retirarse. En medio de una pertinaz campaña mediática de repudio a su presencia, en la que se mezclaba el desprecio por lo indio con el rechazo al Gobierno, las clases medias quiteñas se desmovilizaron negando la conducción del movimiento indígena, dejándolos solos. Esa fue la manera en que las élites, clases acomodadas, autoridades y sectores medios quiteños, indolentes, reaccionaron a la festiva movilización indígena de toma de la ciudad, aislándoles y cercándoles en el vacío de poder, en el que solo mora el desconocimiento y la negación cultural del otro.

\section{La rebelión forajida en la ciudad hostigada}

El tercer momento en que se volvió a evidenciar la cohesión simbólica entre las clases medias, altas y las autoridades locales para conjurar las amenazas a la ciudad, fue en los eventos que derrocaron al Gobierno de Lucio Gutiérrez. En una simbiosis multiclasista, con predominio de los sectores medios, se expresó el repudio a otro Gobierno de comportamientos autoritarios, considerados localmente como hostiles y que provocaron el desbordamiento ciudadano que caracterizó las movilizaciones urbanas. Ocurrió durante la denominada rebelión forajida, acaecida entre febrero y abril de 2005, que volvió a destituir al presidente y cerró el ciclo de luchas sociales disconformes con el desgastado sistema de representación.

Habían transcurrido cinco años desde que se estableció la dolarización y la economía ecuatoriana daba signos de aparente estabilidad. Según Alberto Acosta (2005), se abatió la inflación, con enorme costo social, gracias al crecimiento y altos precios de las exportaciones petroleras, las bajas tasas de interés del mercado internacional y el incremento de las remesas de emigrantes, con lo que el Gobierno de Gutiérrez logró, luego de un consecutivo déficit comercial, un fugaz superávit que en realidad era menor a la tendencia previa a la dolarización y ocultaba 
una enorme pérdida en la balanza comercial, la mayor acaecida desde la dolarización y superior a los años precedentes, situación que era difícil de remontar con los recursos disponibles (48-9). En una pomposa celebración mediática, el Gobierno se atribuyó haber logrado el superávit comercial, lo que en realidad ocultaba una difícil realidad económica.

Apenas empezado su mandato, a inicios de 2003, el presidente declaró austeridad en el manejo fiscal, firmó una Carta de Intención con el FMI, un programa de reformas estructurales con el Banco Mundial y recortó drásticamente las inversiones sociales, transfiriendo a este sector montos considerablemente menores que equivalían a la mitad de las remesas de los migrantes, mientras, por otro lado, haciendo gala de magnificencia y exactitud, cumplía con el pago del servicio de la deuda pública externa, la que en un año se había incrementado en más de la mitad (51). El discurso antineoliberal de la campaña electoral cambió una vez en el poder, por lo que, luego de dieciocho meses y veinte días de colaboración y sintiéndose traicionados, los aliados y colaboradores de izquierda, encabezados por el movimiento indígena Pachakutik, rompieron con el Gobierno de Gutiérrez (Saad 2005, 90).

En una servil pretensión de puntualidad en el pago de las acreencias al servicio de la deuda pública externa, el Gobierno, recurriendo a medidas ortodoxas que desconocían los riesgos de "colusión y uso indebido de información”, incrementó sustantivamente la valorización de los Bonos Global, generando ganancias escandalosas a sus tenedores, entre ellos varios banqueros privados. Para Acosta $(2005,52)$ la estrategia era simple: se recompraba solo la deuda pública externa para financiar el presupuesto público, y de rebote, se cumplía con los acreedores externos.

El presidente continuó con la práctica gubernamental de forzar las leyes con el indiscriminado uso de decretos ejecutivos, por lo que siguiendo las directrices de su ministro de Finanzas se afanó en pagar a los prestamistas, en renovar el perfil del país en el mercado financiero internacional y en ampliar el endeudamiento externo, al tiempo que reducía el gasto público comprimiendo, artificialmente, el aporte del ingreso petrolero al presupuesto y desviando los excedentes del precio del petróleo hacia los llamados "fondos de estabilización" (53). 
Repleta de vivezas financieras que acomodaban la política económica del Gobierno a las políticas ortodoxas liberales internacionales, no había ninguna amenaza de desestabilización económica; al contrario, la gestión gubernamental, con tono entreguista, se mostraba invariable (43). No hubo un "paquetazo" de medidas restrictivas ni era errática la conducción económica, el presidente fue depuesto, a pesar de la relativa estabilidad económica, por una crisis política (De la Torre 2008, 205) con matices de estigmatización cultural.

Fue el carácter autoritario del Gobierno que atropelló la institucionalidad pública y desairó a la capital, cuestión repudiada por la mayoría de la población quiteña, lo que precipitó su caída. El presidente, autodenominado "dictócrata" (Acosta 2005, 51), se mostró errático en la gestión de la política. Luego de la salida de sus aliados de izquierda, de la rotunda pérdida en las elecciones seccionales de 2004 y de la amenaza de juicio político en el Congreso, con una deslucida mezcla de clientelismo y retórica antioligárquica, conformó una nueva alianza populista entre los partidos PSP, PRE, Partido Renovador Institucional Acción Nacional (PRIAN), MPD que marcaría su fatal destino.

El costo de la nueva alianza era el retorno de Bucaram. Con este propósito, impuso una Corte Suprema de Justicia desplazando a la controlada por el PSC, la que custodiada por bandas de matones anuló los juicios a los exgobernantes prófugos por delitos públicos, entre ellos Abdalá Bucaram, y forzó una mayoría parlamentaria que le permitía a este último controlar el Congreso (De la Torre 2005, 110). Literalmente, el Gobierno ocupó todas las funciones del Estado y nuevamente la amenaza de retorno de Bucaram acechaba en la memoria levantisca de los quiteños, no obstante, apoyado en una intensa campaña mediática el presidente se mostró victorioso ante la arremetida de los partidos políticos.

A finalizar el año 2004 ocurrió la primera marcha de protesta, con cerca de cinco mil personas que, aunque duramente reprimida, provocó nuevos eventos de resistencia. Según Augusto Barrera se habían conformado tres ejes de oposición al Gobierno: uno en torno a la tendencia de centroizquierda liderado por la ID y Pachakutik, otro con los colectivos ciudadanos y varias oenegés, y un tercero vinculado al PSC y los jueces destituidos (11). 
Los dos primeros confluyeron en un espacio múltiple, gestados en las marchas del movimiento indígena, con contactos parlamentarios que podían recuperar la capacidad de impugnación ciudadana, al que se invitó al alcalde metropolitano de Quito y al prefecto de Pichincha que habían declarado su oposición al régimen, formándose las asambleas de Quito y de Pichincha respectivamente, en calidad de alianzas cívico-políticas que demandaban la restitución del Estado de derecho. La Asamblea de Quito convocó a la marcha por la democracia, contra el autoritarismo y la corrupción (Barrera 2005, 12).

La respuesta quiteña fue masiva: se estima que más de doscientas mil personas, en su mayoría habitantes de los barrios de clases media y alta, salieron ordenada y pacíficamente en la "mayor marcha de la historia de Quito" (Ortiz 2005, 26), que se dirigió a la plaza de San Francisco, pidiendo la reorganización de la Corte Suprema de Justicia y la rectificación del Gobierno. Los poderes locales mostraron la contundencia de su "reclamo al régimen y la alta sociedad celebraba también la resonancia que su reclamo adquiría en la opinión pública y en nuevos sectores sociales" (Ramírez 2005, 41).

Sin embargo, en las calles y plazas, el sentimiento ciudadano rebasó los propósitos de la marcha, sus dirigentes pedían la restitución de la Corte, mientras entre la ciudadanía emergía con fuerza un sentimiento cívico contra la presencia del presidente; el grito: ¡Lucio fuera!, similar al de años atrás contra Bucaram, estremecía a la gente, ante lo cual las autoridades se mostraron conciliadoras (Barrera 2005, 12). El Gobierno, aparentando comprender los acontecimientos, el mismo día de la marcha, montó un forzado festejo de triunfalismo, "rodeado de una coreografía propia de una cantina de tercera" (12), puso a la ciudad de Quito en su contra al ridiculizar la protesta ciudadana.

Digo "aparentando" porque, como lo ha señalado la mayoría de analistas, Gutiérrez confundió la realidad, subestimó las debilidades de una asamblea de reciente formación y supuso que apuntando el ataque a los partidos opositores, especialmente a la ID que gobernaba el distrito metropolitano y la provincia de Pichincha, podía controlar el descontento. No comprendió que, en realidad, más que los partidos, era la ciudadanía quiteña la que movilizada exigía su renuncia. 
En el transcurso del siguiente mes y medio se sucedieron las movilizaciones callejeras, enfrentadas con las fuerzas de choque gobiernistas. La oposición al Gobierno trató, sin efecto, de empezar un procedimiento de revocatoria del mandato, alcanzó a difundir una estrategia internacional exitosa y el intento de acordar una mayoría parlamentaria fue anulado (13). Mientras tanto, continuaba inalterable el ataque presidencial a los partidos políticos elevando, "ciega, neciamente, los niveles de enfrentamiento con la oposición, lo que además, confundió, como en el caso de Quito, con el enfrentamiento con la propia ciudad” (Ortiz, 2005, 26).

Enredado en la embestida a los partidos quiteños, en poco tiempo el presidente ahondó su irreversible descrédito en la capital, cada ataque a los políticos era un menosprecio más a la ciudad, no porque hubiera alguna relación orgánica entre partidos políticos y ciudadanía, sino por la errática acción gubernamental que enmarañaba a la oposición con Quito, como otrora ocurrió con Bucaram, que confundió centralismo con capitalidad, reviviendo en la memoria colectiva de la ciudadanía quiteña sus funestos sucesos.

El regreso de Bucaram a Guayaquil la noche del 2 de abril de 2005, a decir de Carlos de la Torre, colmó el desborde de la "indignación moral y estética" de las clases medias y altas capitalinas activadas en las protestas contra Gutiérrez, la que fue amplificada por la mayoría de editorialistas y programas de opinión de radio y televisión en la Sierra (2005, 104). El eufórico mitin de recibimiento a Bucaram se realizó en la zona de regeneración urbana, convertida en hito urbanístico segregacionista del Gobierno municipal socialcristiano, en el que días antes se había realizado la Marcha Blanca por Guayaquil en oposición al Gobierno de Gutiérrez, ahora era invadida por una muchedumbre de humildes seguidores del líder populista que exhibía su disposición a apropiarse de los espacios del poder local.

Como lo explicó De la Torre (2005), estudioso del fenómeno populista, el mitin, una mezcla de aglomeración, caballos, vehículos y guardaespaldas, se organizó como un show mediático de amplia difusión, "retransmitido en vivo por varios canales de televisión" y mostró que las cosas no habían cambiado, continuaba el despotismo encubierto 
de populismo: junto con la exaltación de "las virtudes del líder y del pueblo", estaba una calculada desatención por la suerte de sus seguidores, una apuesta irresponsable ante eventuales contingencias innecesarias, creando situaciones de riesgo. "Todo, para que este no sea un mitin político más, para que no se lo olvide fácilmente” (106).

El show mediático de repatriación del prófugo absuelto provocó el efecto contrario. Lejos de fortalecer al Gobierno caldeó los ánimos quiteños, amplificándose las movilizaciones de protesta ante los reiterados atropellos gubernamentales a la ciudad, en las que se visibilizó el distanciamiento entre los líderes políticos que elevaban petitorios formales y la ciudadanía que indignada demandaba la dimisión presidencial. El grito coreado en todas las movilizaciones: "Que se vaya Bucaram y también su edecán” (110) sintetizó el resentimiento de quienes en las calles y plazas protestaron contra el Gobierno de Gutiérrez.

Ese era el ambiente cuando la Asamblea de Pichincha convocó a un paro provincial que no tuvo mayor trascendencia. Se mostró mal organizado, evidenció divisiones en sus propósitos entre las organizaciones participantes, falta de acuerdos sobre la dimisión presidencial, errores logísticos y operativos en las movilizaciones, así como posturas divergentes entre el alcalde de Quito y el prefecto de Pichincha, lo que fue interpretado por la gente como un inoportuno forcejeo por el liderazgo y un debilitamiento de los ánimos ciudadanos (Barrera 2005, 13).

El Gobierno organizó una burlesca contramarcha en el Centro Histórico, bailando al compás de la tecnocumbia, y se ufanó públicamente del escaso respaldo a los políticos, lo que fue percibido como una bravata adicional que aceleró la indignación ciudadana (Ramírez 2005, 46). Casi de inmediato, en cadena nacional, presuntuosamente, el presidente volvía a mostrarse vencedor en la contienda contra los quiteños. Al final de la jornada reinaba en la ciudad una sensación de infortunio por el fallido paro y de represado coraje con el fatuo presidente.

Al finalizar la tarde de ese mismo día, un medio de comunicación alternativo, radio La Luna, convocó a la ciudadanía quiteña a rechazar la "victoria presidencial" y continuar con las protestas, invitando a un “cacerolazo nocturno” que congregó a más de cinco mil personas en la 
avenida de los Shyris, declarada eufemísticamente "territorio libre", ya que anteriormente era el sitio de las paradas militares y se había convertido en el epicentro simbólico de la protesta ciudadana (Saad 2005, 77). Los manifestantes hicieron una marcha y un plantón en la cercana Corte Suprema de Justicia, donde se reeditó la represión policial, lo que, en lugar de disuadir a los manifestantes, enardeció sus ánimos. En la noche, un grupo de manifestantes se dirigió a la casa del presidente a exigir su renuncia; a la mañana siguiente amenazó con ponerles “juicio penal a esos forajidos que no eran del pueblo” (La Hora 2005), lo que bastó para detonar el inédito desborde social.

El término forajido unificó, inesperadamente, a la diversidad de personas, explica Bustamante (2005), para quien "algo preexistía” en la amalgama de "clase media, clases altas y barrios populares", relacionada con la sensación de amenazas contra la ciudad, provenientes de grupos pagados o convencidos de tomarse la ciudad y castigar a los forajidos, o del discurso populista que vulneraba a la clase media capitalina que aprendió a vivir con "valores particularistas" (58). Eso explica que las movilizaciones ocurrieran no por medio de mecanismos políticos ni mediante la trama de la sociedad civil, sino por los contactos personales entre las familias, amistades, compañeros de trabajo y vecinos de las clases medias, comunicadas por un "lenguaje que además de informal, reclamaba derechos y dignidad" (59).

Lo cierto es que, a partir de ahí, todas las declaraciones provocaron nuevas formas de lucha ciudadana, autoidentificadas como "forajidas". Durante ocho días, especialmente en las noches, se tomaron la ciudad, sucediéndose convocatorias autogestionadas en las que se ideaban eventos de protesta originales: el "cacerolazo", "tablazo", "rollazo", "bicicletazo", "chamizaso", marchas, escraches, plantones y vigilias en horarios y lugares disímiles; la mayoría con carácter festivo y humorístico, construyeron colectivamente una "narrativa en línea con actores-reporteros" que enlazaban un "potente sentido de pertenencia y de identidad colectiva” (Barrera 2005, 13). Emergió una pluralidad de protagonismos colectivos que conectaban la cotidianidad de la vida urbana con los parques, esquinas, calles y plazas convertidas en móviles y temporales 
focos de protesta y de enfrentamientos ciudadanos con la policía y las huestes gobiernistas. El descontento ciudadano se robustecía por ondas reactivas cada vez más continuas y fuertes, por "cada maniobra que el régimen emprendía” (Ramírez 2005, 46). La inoperancia gubernamental estimulaba la creciente efervescencia social.

En sinnúmero de barrios, especialmente del centro norte de la ciudad, incontables personas emprendieron sui géneris combinaciones de trabajos diurnos y protestas nocturnas, activándose nutridas asambleas territoriales y temáticas, microconcentraciones, marchas, plantones, bloqueos de calles y avenidas. A las tradicionales formas de protesta, se sumaron otras en sintonía con la cotidianidad cultural de los disímiles estamentos sociales movilizados, exhibiendo, en conjunto, lo que se consideró como "inéditos repertorios de contestación” (48-72), que excedieron a todas las instancias formales de oposición.

Deslegitimado, el Gobierno declaró el estado de emergencia solo en el DMQ, y en su desesperación por ganarse a la gente destituyó a los miembros de la Corte Suprema de Justicia, pero no logró el efecto esperado, más bien recrudecieron las protestas, el Concejo Metropolitano se declaró en rebeldía frente al estado de emergencia y pidió la salida del "dictador Gutiérrez" (Ortiz 2005, 28). La medida gubernamental no fue acogida por la ciudadanía capitalina, tampoco por las autoridades del distrito ni por el ejército, por lo que el Gobierno, desautorizado, suspendió la medida.

Las protestas surgían en distintos puntos de la ciudad y se replicaron en otras ciudades del país. El martes 19 de abril el Gobierno llevó a la capital tres mil integrantes de la Federación de Indígenas Evangélicos del Ecuador (FEINE), oriundos de la Sierra central que pasaron el día en la plaza de San Francisco. Por la tarde, una inmensa manifestación de más de sesenta mil personas salió desde la Cruz del Papa en dirección a la Plaza de la Independencia, la que, aunque fue disuelta brutalmente (28), se reagrupaba en distintos puntos tratando de llegar al centro.

La madrugada del 20 de abril, en medio de las convergentes marchas ciudadanas que buscaban tomarse la plaza y el Palacio de Gobierno, el presidente nuevamente anunció al arribo de doscientos buses de 
"simpatizantes leales", provenientes, en cambio, de las provincias costeras y amazónicas (29), lo que recrudeció la indignación quiteña ante la amenaza de toma de la ciudad. El alcalde y el prefecto, en reacción, bloquearon los ingresos a la ciudad con vehículos y maquinaria pública, llamaron a los residentes en los valles circundantes a cerrar el paso a los invasores, al tiempo que todos los barrios quiteños fueron convocados a proteger la ciudad. Una desatinada orden ministerial puso a los estudiantes secundarios en las calles, contribuyendo al desorden y el caos (29).

Improvisadamente, el Gobierno tomó varias medidas de desagravio tratando de revertir la rebelión capitalina, pero era tarde, "todo Quito ya era una fogata de libertad” (Saad 2005), no pudo detener la caída presidencial ocurrida ese mismo día, cuando las Fuerzas Armadas desconocieron al Gobierno, la policía pasó de la represión a los abrazos con las personas movilizadas (90) y los legisladores reunieron al Congreso en una sede distinta en la que destituyeron al presidente por "abandono del cargo" y dieron paso a la subrogación del vicepresidente. El presidente derrocado protagonizó su propio sainete de escape del Palacio de Carondelet, refugiándose en la Embajada del Brasil y luego en una precipitada fuga hacia el aeropuerto (Ramírez 2005, 65), sitios hasta los que llegó la marea forajida.

Las movilizaciones de abril, en un hecho insólito, se mantuvieron activas durante varios días después de derrocado el Gobierno, en una suerte de vigilancia ciudadana alerta a erradicar cualquier posible rebrote del gutierrato. Es que la rebelión quiteña reclamó una clara factura societal, ocurrió por fuera y, en determinados momentos, en oposición a cualquier estrategia partidaria u organizativa, expresándose en múltiples acciones de protesta urbana, singulares y desperdigadas, que congregaron espontáneamente a masivas y diversas gentes, especialmente de clase media (73).

Así, las movilizaciones quiteñas acaecidas durante los momentos de inestabilidad política, que condujeron a los derrocamientos presidenciales, se dieron, cada una, en condiciones socioeconómicas y políticas distintas y tuvieron consecuencias diferenciadas en la estructura del país, pero también rebelaron continuidades relacionadas con las 
disputas culturales en el DMQ, algunas de las que paso a señalar para cerrar esta sección. Me refiero al escenario predilecto de la lucha social en los espacios públicos quiteños, al protagonismo predominante de las clases medias y la disímil participación de los sectores populares o de la población humilde, y a las narrativas estigmatizadoras compartidas entre la gente que cohesionó sus comportamientos y ratificó el orden regulatorio de la ciudad.

Las tres coyunturas de movilización social desembocaron en la destitución de los presidentes por parte del Congreso y fueron ratificadas por las Fuerzas Armadas, evidenciando el declive progresivo de la institucionalidad democrática, pues el principio de que el pueblo soberano elige a sus autoridades se cumplió parcialmente, los tres presidentes fueron derrocados de facto, en las calles, aunque ganaron elecciones libres (De la Torre 2008, 203). La movilización callejera se impuso a la representación.

Los medios de comunicación, la ciudadanía movilizada e incluso los propios gobernantes defenestrados compartían una misma visión cultural de que en las calles se ganan y se pierden los Gobiernos, y que las protestas callejeras, como expresión del descontento ciudadano, tienen la fuerza para deponer a los presidentes. La afirmación de que la democracia se hace en las calles, como lo dijo Carlos de la Torre, es una creencia nacida en el período del populismo de Velasco Ibarra, que levantó un imaginario político arraigado en el sistema de partidos acerca de que lo democrático se entiende como la ocupación de los espacios públicos, en los que se escenifican las ritualidades litúrgicas entre los líderes y la voluntad popular (208).

El credo de que las movilizaciones callejeras remueven a los presidentes funcionó como un "mito movilizador" durante el ciclo de movilizaciones en defensa de la capitalidad. La lucha urbana como ocupación de los espacios públicos tiene, al menos, dos aspectos a considerar. Fueron tomas de facto de las multitudes movilizadas para ocupar, posicionarse simbólicamente, calles, plazas, parques y los lugares en los que se ejerce el poder, en reacción al mal uso o el despilfarro de los bienes y recursos públicos por parte de gobernantes con actitudes clientelares y caciquistas. La ocupación simbólica implicó confrontaciones y des- 
alojos: si en las calles se ejerció la democracia, también se la combatió. En los tres casos, los gobernantes montaron contraofensivas, mítines y fuerzas de choque callejeras para dispersar y frenar a la ciudadanía movilizada contra Bucaram y Gutiérrez, para bloquear y frenar la marcha indígena contra Mahuad.

No fueron solo confrontaciones episódicas entre bandos políticamente contrapuestos disputándose edificios, calles y plazas, sino momentos de efervescencia ciudadana signados por la apropiación de los espacios públicos como expresión de la preservación de las adscripciones identitarias territoriales; en ese sentido, fueron ocupaciones de lo público activadas por un localismo en defensa de lo propio. Las amenazas de transgresión a la geografía de las identidades territoriales quiteñas, con irrupciones de grupos ajenos a la vida de la ciudad como las "hordas bucaramistas", la toma indígena de la ciudad y las "huestes leales gutierristas", desataron en unos casos la euforia por la ocupación de los espacios públicos, siempre dentro de los perímetros socialmente valorados por las clases medias y altas capitalinas; en el otro, la desmovilización y adhesión al desprecio a los indígenas, arrinconándoles en desolados lugares públicos.

Las clases medias capitalinas, en las últimas décadas, experimentaron un complejo y contradictorio proceso de crecimiento y contracción; se expandieron cuantitativamente en la ciudad, al tiempo que vieron descender sus condiciones de vida y trabajo. Aunque no es un fenómeno generalizado a todas las clases medias, dada su múltiple segmentación, hay estratos medios favorecidos con la expansión metropolitana de la ciudad, y también hay estratos medios con tendencia al empobrecimiento (Paz y Miño 2006, 89). A pesar de las distinciones socioeconómicas, las clases medias y altas quiteñas fueron los principales actores protagonistas de las movilizaciones contra Bucaram y Gutiérrez, y se mantuvieron en un silencio cómplice en los eventos contra Mahuad.

En la síntesis de actores de las movilizaciones realizada por De la Torre (2008), se argumenta que en 1997, durante las movilizaciones en contra de Bucaram, las clases medias estuvieron en el centro de una convergencia multiclasista que incluyó a trabajadores, empresarios, cla- 
ses altas, la Asamblea de Quito, jóvenes de izquierda, mujeres, indígenas y sectores populares. En el año 2000, en las movilizaciones opositoras a Mahuad, en cambio, las clases medias no participaron, los protagonistas fueron los indígenas aliados con la Coordinadora de Movimientos Sociales, oficiales menores y jóvenes de izquierda. Y en 2005, en las movilizaciones que depusieron a Gutiérrez, nuevamente las clases medias asumieron el protagonismo principal, junto con las clases altas, las oenegés, grupos de mujeres y jóvenes (211).

Varias son las razones que explican por qué se movilizaron las clases medias. Se activaron en defensa de sus intereses y privilegios aparentemente desplazados por los Gobiernos populistas; también fueron provocadas por la osadía de grupos extraños que se insubordinaron de los lugares que ocupan en la jerarquía social, incomodando y desconcertando a la clase media; asimismo, sus movilizaciones obedecieron a que son instrumentales a la democracia, cuando "aseguran su posición social” se agota su afán democrático y buscan desalojar del poder a quien "pone en riesgo frente a las élites y frente al pueblo, su propia ubicación social" (Bustamante 2005, 63). Otra motivación de tipo "bacteriano" está relacionada con atribuirle la capacidad de percepción del peligro y la amenaza a las clases medias ante las coacciones externas, pues funcionan como una especie de antídoto que actúa cuando avizora la presencia de elementos ajenos al medio, un "anticuerpo que se moviliza para restablecer el equilibrio del sistema” (Burbano 2005, 24).

En Quito la clase obrera, otrora actor relevante en las protestas contra las políticas de ajuste estructural en la década de los 80 , se mostró desgastada y tuvo su "último protagonismo en la movilizaciones contra Bucaram” (De la Torre 2008, 212). Mientras tanto, las organizaciones barriales que habían empezado su decline organizativo tuvieron una tenue participación en las movilizaciones contra Bucaram, esporádicamente algunos comités barriales del noroccidente y suroriente de la ciudad apoyaron las entradas y desplazamientos del movimiento indígena en los sucesos que derrocaron a Mahuad. Estuvieron ausentes en las movilizaciones que derrocaron a Gutiérrez, pero presentes en algunas de las marchas que se hicieron a favor del Gobierno, atrapadas 
como estaban en la estrategia asistencialista gubernamental que "ofrecía recursos, favores, víveres y festejos” en los barrios periféricos capitalinos, organizaron la Asamblea Popular de Quito integrada por unos cuantos barrios y comunidades desatendidas por el municipio, encabezada por la Federación de Barrios del Sur y la Unión de Comerciantes del Sur, con el propósito de "enfrentar a la Asamblea de Quito y respaldar al régimen” (Ramírez 2005, 68).

Por su lado, los pueblos indígenas en la ciudad mostraron comportamientos distintos. Las comunas del pueblo kitu kara, alineadas con la CONAIE, tuvieron un mínimo involucramiento en las movilizaciones contra Bucaram, organizaron el apoyo logístico en las entradas de la marcha indígena contra Mahuad y estuvieron ausentes en la rebelión forajida (Simbaña 2015); entre los indígenas migrantes, los de filiación evangélica se involucraron en los eventos de apoyo al Gobierno gutierrista. Y las organizaciones de afroquiteños tampoco se implicaron en ninguna de las movilizaciones quiteñas, debido a que estuvieron involucradas en sus propias agendas organizativas en los Gobiernos de Bucaram y Gutiérrez, mientras ante Mahuad, debido al distanciamiento durante su alcaldía, tampoco participaron en su derrocamiento.

Finalmente, otra continuidad de las movilizaciones quiteñas en los tres episodios de destitución presidencial fueron los significados jerárquicos exhibidos por las consignas, gritos, proclamas y discursos callejeros que configuraron las narrativas de las protestas. En los tres episodios, si bien se desplegaron retóricas democratizadoras, estuvieron teñidas de expresiones de inferioridad, racismo y xenofobia hacia los Gobiernos y sus aliados, o contra el movimiento indígena en la toma de la ciudad.

Más allá del humor y la ironía que matizaron las protestas, aupados por los editorialistas de la prensa capitalina, los gobiernistas y opositores fueron semánticamente alojados en el campo de lo insensato. Conforme el libreto populista, dice De la Torre, que estigmatiza a los seguidores de los líderes como "masas de ignorantes y desorganizadas", abundaron las alocuciones mediáticas que reconocían a unos como ciudadanos y a otros como mercenarios, a los quiteños como "gente culta" distinta de las cuadrillas invasoras de provincianos, diferenciando a los capitalinos de los “monos” costeños y de los “jíbaros” amazónicos (210). 
Detrás de las proclamas en las protestas, se entronaron los valores del orden y la modernidad metropolitana como ejercicio del coloniaje entrelazado con la democracia. La retórica del quiteñismo supo manipular las injusticias sociales de la dominación y discriminación, ostentando su similitud con las clases altas; se desveló una ecléctica mezcla de protección del orden de la ciudad, de irritación ante la corrupción de los gobernantes y de cuestionamiento al neoliberalismo que había acentuado las injusticias de la convivencia en la ciudad y el país. La mezcla conservadora de indignación y rebeldía ciudadana explica la paradójica excitación moral compartida entre quienes salieron a las calles a protestar, pero se desmovilizaron cuando los indios entraron a la ciudad.

Como lo señaló De la Torre, las reacciones de las clases medias y altas también obedecieron a que profesan valores estéticos señoriales para el ejercicio de la autoridad, los que fueron desairados por los dos gobernantes, incluían desde los atributos personales, los símbolos de la majestad que reviste el cargo presidencial, la solemnidad y ceremonia cívica en la cotidianidad del poder, hasta cierta incomodidad sobre el “origen social y étnico de los presidentes" (2008, 213). A los quiteños les fastidió las maneras burdas y vulgares de Bucaram y Gutiérrez, quienes fueron tildados de "advenedizos sociales por sus orígenes étnicos" de "turco contrabandista" el uno, de "amazónico color verde" el otro (213), explicó el analista.

Las movilizaciones sociales en los tres eventos no llegaron a situaciones extremas de anomia social, si bien en la rebelión forajida desbordaron a los partidos y liderazgos políticos, todas ocurrieron dentro de la estructura regulatoria de la sociedad quiteña, exagerada por la grandilocuencia de la narrativa mediática. Refiriéndose a los atropellos de los gobernantes en la capital, Bustamante (2005, 61-2) consideró que mostraron el "orden feudal” de la sociedad quiteña con jerarquías, privilegios y fueros, en los que "cada quién debe saber a quién puede atropellar, qué atropellos puede sufrir, y qué apoyos debe buscar para minimizar estos riesgos".

Las irrupciones arbitrarias en la jerarquía social, efectivamente, encuentran sus límites en lo que el poder les permite. En los tres episo- 
dios, de distintas maneras, las arbitrariedades gubernamentales no distinguieron los atropellos, rebasaron este umbral, con lo cual precipitaron los fatídicos desenlaces. Así, los presidentes fueron depuestos por las movilizaciones ciudadanas ocurridas en los espacios públicos urbanos, por las presiones de las clases medias y el movimiento indígena, apoyados por dinámicas multiclasistas y motivadas desde narrativas de conservación y rebeldía en contra de las arbitrariedades gubernamentales.

Tras las destituciones presidenciales, en cada caso, se desactivaron las movilizaciones sociales, los espacios públicos simbólicamente ocupados retornaron a su fragmentación cotidiana, los notables recuperaron el control de la ciudad y paulatinamente el orden se restituyó. Se habían removido los autoritarismos del Gobierno central, pero el país continuaba impactado por la crisis nacional del sistema de representación, el que no se había modificado. La ciudad de Quito, escenario principal de las movilizaciones, completó el ciclo en defensa de la capitalidad, y se aprestaba a continuar en el proceso de consolidación metropolitana.

Recapitulando, con la expansión metropolitana de la ciudad, se reactivó la tendencia a la propagación del imaginario blanco-mestizo como factor cohesionador de la nación y de homogeneidad en la adscripción quiteña, la que cargada de prejuicios raciales que estigmatizaban las diferencias étnicas y culturales se irradió como referente de identidad urbana en los distintos estratos de la sociedad capitalina. El "quiteñismo", reavivado con la expansión metropolitana, representaba un conjunto de valores y prácticas de desprecio por lo extraño y lo foráneo, encajado en un falso cosmopolitismo que se avergonzaba de las diferencias culturales.

En este ambiente las comunas del pueblo kitu kara resistieron a las presiones inmobiliarias que el crecimiento urbano ejerce sobre sus territorios ancestrales, además de que emprendieron en un proceso de etnogénesis para el fortalecimiento de su identidad, demandando autogobierno, territorio, idioma y cultura comunal, esto es una agenda del pueblo indígena diferenciada de las prácticas blanco-mestizas en el distrito metropolitano. Los migrantes indígenas, en cambio, establecieron sus propias redes familiares y de afinidad, proyectando la continui- 
dad rural urbana con la que emprendieron diversas formas de inserción comunitaria en la ciudad. El pueblo afroquiteño debió enfrentar el estigma racial de negación de su identidad urbana, para lo cual asumió una estrategia de representación y negociación directa con el municipio metropolitano, en busca del reconocimiento y la consecución de sus derechos ciudadanos, reemplazando la movilización con la contestación cultural. Y los episodios de efervescencia social fueron provocados por las clases medias y altas movilizadas en defensa de la capitalidad, con los que ratificaron los valores prescriptivos de la jerárquica vida en la ciudad de Quito. 